\title{
INTRODUÇÃO À BIOCRISTALOGRAFIA COM O ESTUDO \\ ESTRUTURAL DA QUINASE DEPENDENTE DE CICLINA 2 (CDK2) COMPLEXADA COM INIBIDORES
}

Walter Filgueira de Azevedo Júnior

$a k$

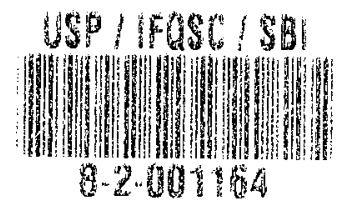

Tese apresentada ao Instituto de Fisica de São Carlos, da Universidade de São Paulo, para obtenção do título de Doutor em Ciências: Física aplicada.

Orientadora: Profa. Dra. Yvonne Primerano Mascarenhas

\section{São Carlos}

1997 
Azevedo, Walter Filgueira de, Jr. Introdução à Biocristalografia com o estudo estrutural da quinase dependente de ciclina 2 (CDK2) complexada com inibidores/ Walter Filgueria de Azevedo Júnior. --São Carlos, 1997.

$148 \mathrm{p}$

Tese (Doutorado)--Instituto de Física de São Carlos, 1997.

Orientadora: Profa. Dra. Yvonne Primerano Mascarenhas.

1. Cristalografia 2. Proteinas.

I. Título. 
MEMBROS DA COMISSÃO JULGADORA DA TESE DE DOUTORADO DE WALTER FILGUEIRA DE AZEVEDO JUNIOR APRESENTADA AO INSTITUTO DE FÍSICA DE SÃO CARLOS, UNIVERSIDADE DE SÃO PAULO, EM 23/04/1997.

\section{COMISSÃO JULGADORA:}

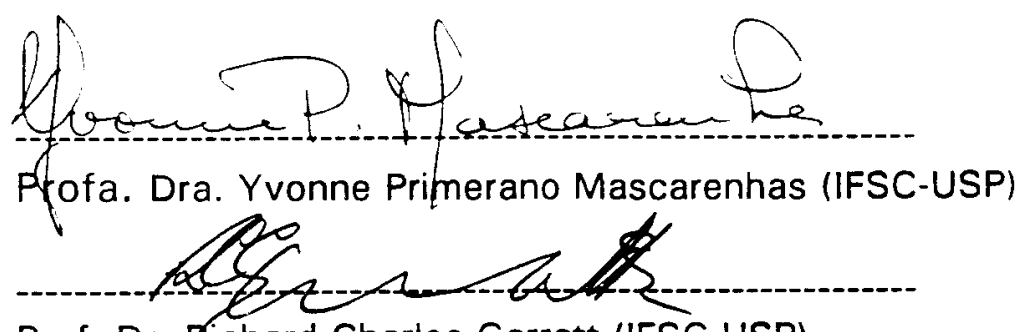

Prof. Dr. Richard Charles Garratt (IFSC-USP)

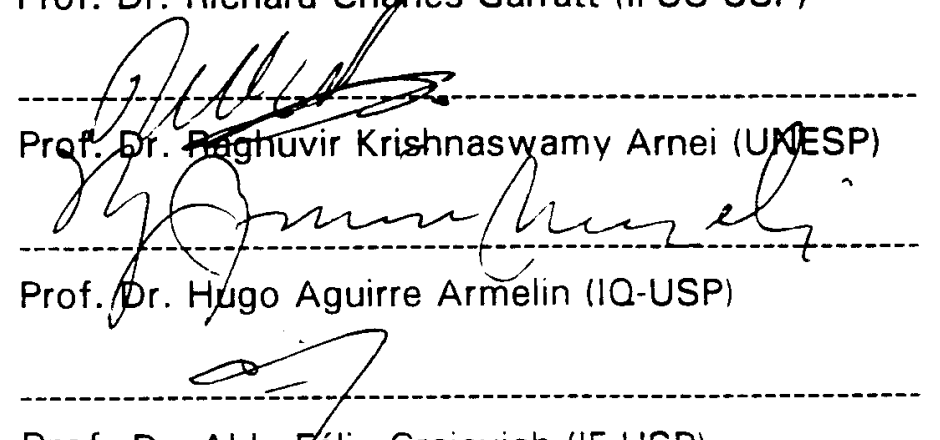

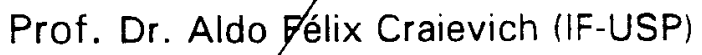

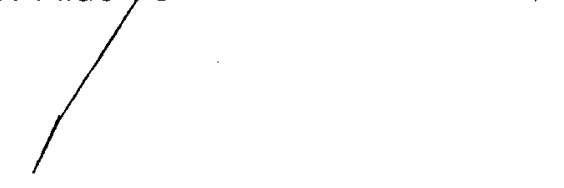


A realização desta tese foi possivel graças ao suporte dado pelas Instituições de apoio à pesquisa: FAPESP. FINEP, CNPq e ao Department of Chemistry, University of Califomia at Berkeley e Departamento de Física e Informática do Instituto de Físıca de São Carlos da Universidade de São Paulo. 
Dedico este trabalho ao meu filho

Linus, à minha esposa Elma e aos meus pais Walter e Marion. 


\section{AGRADECIMENTOS}

-À profa. Dra. Yvonne Primerano Mascarenhas, pela orientação, ensinamentos, apoio e amizade, sem os quais este trabalho não seria possível.

-Ao Prof. Dr. Sung-Hou Kim (University of California at Berkeley) que tão gentilmente me aceitou em seu laborátorio e meu deu a oportunidade de aprender e participar de um projeto de pesquisa tão interessante.

-À Dra. Jaru Jancarick ( University of California at Berkeley) pela amizade e valiosos ensinamentos sobre cristalização de macromoléculas biológicas.

-Ao Prof. Dr. R. K. Arni (IBILCE/UNESP S. J. Rio Preto) pela a amizade e confiança no meu trabalho.

-Aos Professores Dr. Eduardo Ernesto Castellano, Dr. Glaucius Oliva, Dr. Julio Zukerman-Schpector, Dr. Richard Charles Garratt e Dr. Eduardo Horjales Reboredo pelos valiosos ensinamentos cristalográficos.

-Ao amigo Fernando Cachucho da Silva pela amizade e companherismo que compartilhamos durante todos estes anos.

-Aos colegas bolsistas do grupo de cristalografia: Maria Teresa da Silva Giotto, Valma Martins Barbosa, Dulce Helena Ferreira, Maria Cristina Comuniam Ferraz, Norma Bianca Sais Cretelli, Marcos Roberto de Mattos Fontes, Luís Fernando Delboni, José Geraldo Nery, André Maurício Brinatti, Paulo Sérgio Lopes de Oliveira, Ezequiel Horácio Panepucci, Jorge lulek e José Dalton Cruz Pessoa, pelo apoio, estímulo e amizade.

-Aos técnicos Sr. Carlos A. Trombella, Wanda Dragheta Perussi de Jesus e José Augusto Lopes da Rocha, pela colaboração na parte prática.

-Ao técnico Valdir Melchior pela colaboração no uso do computador.

-À secretária Maria Helena Braga de Carvalho, pela ajuda e amizade.

-Ao Ítalo pelas cópias.

-Aos escritores Isaac Asimov e Arthur C. Clark por me mostrarem o caminho... 


\section{SUMÁRIO}

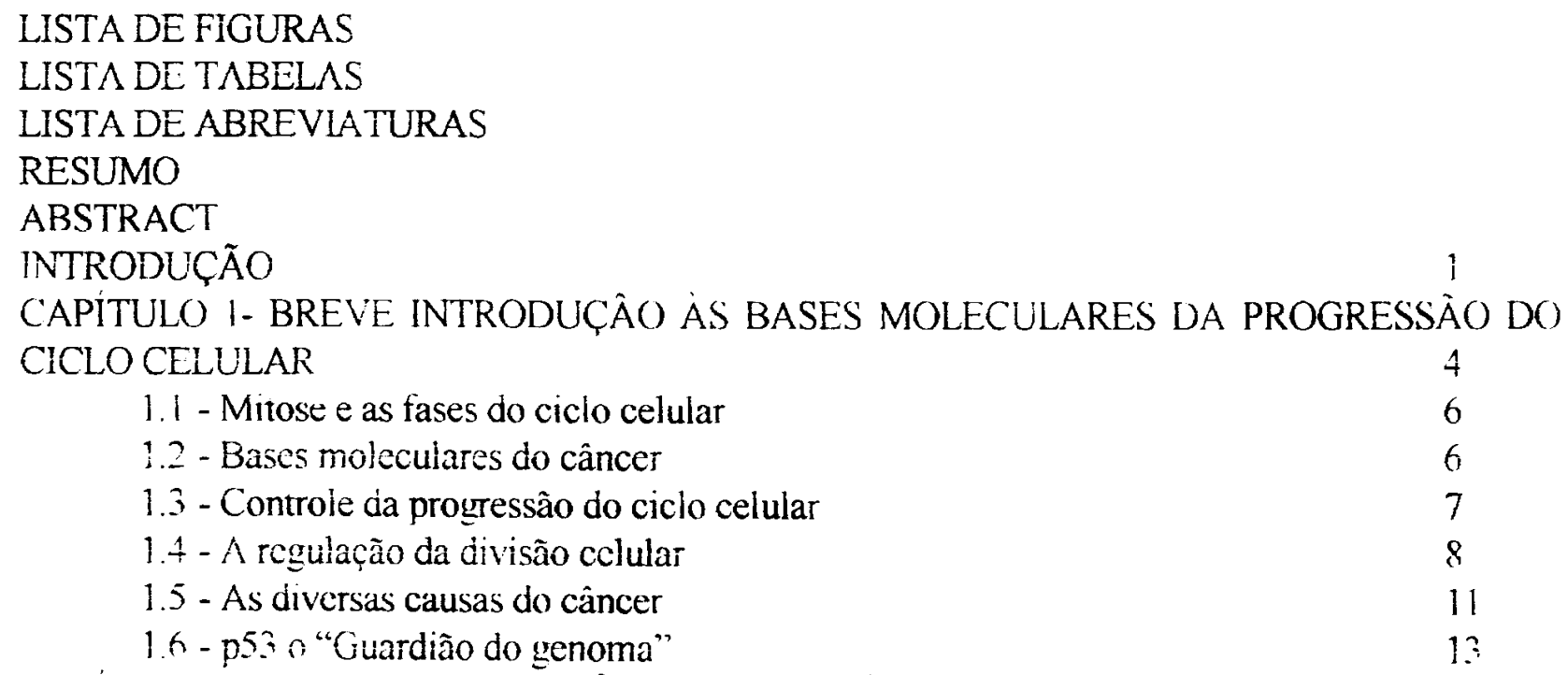

CAPITULO 2 - INTRODUÇÃO AOS METODOS PARA PURIFICAÇÃO DE MACROMOLECULAS BIOLOGICAS

2.1 - Introduçào a puriñcação de macromoleculas biolog̣cas 10

2.2 - Cromatografia 16

$\begin{array}{ll}2.2 .1 \text { - Cromatografia de troca ionica } & 17\end{array}$

2.2.2 - Filtração em gel 23

2.2 .3 - Cromatografia de afinidade 25

2.3 - Cromatografia liquida de alto desempenho 26

2.4 - Sistema convencional para purificação de macromoléculas biológicas 26

2.5 - Determinaçâo espectrofotométrica das quantidades de proteinas e ácidos nucléicos

27 - Purificacìo dis CDK? 28

CAPITULO : - CRISTALIZAČ̃O DF MACROMOLECULAS BIOLOGICAS

$3.1-$ Introdução

3.2 - Prncipios gerais para cristalizaçào de macromolecuias biologicas

3.2 .1 - Pureza da macromolécula biológica 35

3.2 .2 - Solubilidade e Supersaturação 3.5

3.2 .3 - Nucleaçầo, crescimento e cessaçâo de crescimento 36 ,

3.3 - Conceitos sobre solubilidade 36

3.4 - Solubilidade de macromoléculas biológrcas 37

3 S- S Sallmy-me Salme-out 39

3.6-Digramas de fases de macromoleculas biologicas 42

3.7 - Mecanismos de crescimento de cristal.

3.8 - Análice macroscopica des mecanismos de crescimento de cristais

3.-Crescimerio de cristals de macromoleculas biologicas no espaço to

3. Tecmeas de crisulizaça de macromoleculas hiolomicas

3.i : - I metoco da matriz esparsa (Fatorial) 48 
3.11.1 - Aplicação do método da matriz esparsa $\quad 50$

3.12 - O método da matriz esparsa passo a passo 51

3.12.1 - Regras gerais para a aplicação do método da matriz esparsa 52

3.12.2 - Experimento inicial de cristalização usando o método da matriz esparsa $\quad 52$

3.12 .3 - Melhoria das condições de cristalização 53

3.12.4 - Exemplo de cristalização de uma macromolécula biológica 54 CAPÍTULO 4 - DIFRAÇÃO DE RAIOS-X

4.1- Introdução $\quad 55$

4.2- Espalhamento Thomson $\quad 55$

4.3- Espalhamento Compton $\quad 56$

4.4- Espalhamento por elétrons 56

4.5- Fator de espalhamento atômico $\quad 57$

4.6- Espalhamento de raios-X por uma molécula 59

4.7- Espalhamento de raios-X por um cristal $\quad 60$

4.8- Espaço recíproco $\quad 62$

4.9- Lei de Friedel 66

$\begin{array}{ll}\text { 4.10- Densidade eletrônica } & 67\end{array}$

4.11- O problema da fase 68

CAPÍTULO 5 - PREPARO E COLETA DE DADOS DE DIFRAÇÃO DE RAIOS X DOS CRISTAIS DE CDK2 EM COMPLEXO COM INIBIDORES

5.1 - Introdução $\quad 69$

$\begin{array}{ll}\text { inibidores } & 69\end{array}$

5.2 - Embebição (soaking) e co-cristalização de complexos binários de CDK2 com dois

5.3 - Montagem dos cristais do complexo CDK2-Roscovitine 71

$\begin{array}{ll}5.4 \text { - Danos por radiação } & 72\end{array}$

$\begin{array}{ll}5.5 \text { - Crio-cristalografia } & 73\end{array}$

5.6 - Sistema de coleta de dados R-AXIS IC $\quad 78$

$\begin{array}{lr}5.6 .1 \text { - Ânodo rotatório } & 80\end{array}$

5.6.2 - Cristal monocromador $\quad 80$

5.6.3 - Espelhos focalizadores $\quad 81$

$\begin{array}{ll}5.6 .4 \text { - Colimador } & 81\end{array}$

5.6.5 - Câmara de oscilação

$\begin{array}{ll}5.6 .6 \text { - Placa de imagem } & 89\end{array}$

5.7 - Coleta e processamento de dados usando o R-AXIS IIC 90

$\begin{array}{ll}\text { 5.7.1 - Alinhamento do cristal } & 92\end{array}$

5.7.2 - Coleta e processamento das imagens Still 93

5.7.3 - Coleta e integração das imagens de oscilação 96

$\begin{array}{ll}5.7 .4 \text { - Escalonamento das imagens } & 100\end{array}$

5.8 - Resolução 103

5.9 - Informações sobre a coleta de dados dos cristais de CDK2-DFP e CDK2-Roscovitine

CAPÍTULO 6 - ESTRUTURAS DA CDK2 HUMANA EM COMPLEXO COM DOIS INIBIDORES $\quad 104$

$\begin{array}{ll}6.1 \text { - Introdução } & 104\end{array}$

6.2.1 - Substituição molecular 104 
6.2.2 - Determinação da estrutura do complexo CDK2-DFP

6.3.1 - Refinamento da estrutura do complexo CDK2-DFP

6.3.2 - Refinamento da estrutura do complexo CDK2-Roscovitine 118

6.4 - Conformação geral da proteína e mecanismo catalítico 120

6.5 - Conformação do inibidor DFP no bolsão de ligação 125

6.6 - Conformação do inibidor Roscovitine no bolsão de ligação 131

6.7 - Complementaridade geométrica 131

CAPÍTULO 7 - CONCLUSÃO

7.1 - Introdução 135

7.2 - Interação CDK2 e DFP 135

7.3 - Interação CDK2 e Roscovitine 137

7.4 - Comparações entre os cinco ligantes de CDK2 137

7.5 - Considerações finais $\quad 142$

REFERÊNCIAS BIBLIOGRÁFICAS 144

APÊNDICE 1 - CONDIÇÕES DE CRISTALIZAÇÃO DO MÉTODO DA MATRIZ ESPARSA APÊNDICE 2 - ARQUIVOS DE TOPOLOGIA USADOS NO REFINAMENTO DO DFP APÊNDICE 3 - ARQUIVOS DE TOPOLOGIA USADOS NO REFINAMENTO DO ROSCOVITINE 


\section{LISTA DE FIGURAS}

Figura 1.1. As fases do ciclo celular 4

Figura 1.2. As fases da mitose $\quad 5$

Figura 1.3. Diagrama simplificado da participação dos complexos de ciclina com CDK nas diferentes fases do ciclo celular 7

Figura 1.4. Etapas na ativação e desativação do complexo CDK2-Ciclina A 10

Figura 1.5. Etapas na ativação e desativação do complexo CDC2-Ciclina B

Figura 1.6. Etapas na ativação e desativação da p53 14

Figura 2.1. Ilustração da troca iônica 18

Figura 2.2. Separação por troca iônica 19

Figura 2.3. Misturador de gradiente, usado para gerar gradientes lineares 21

Figura 2.4. Fórmula quimica dos trocadores iônicos baseados em celulose 22

Figura 2.5. Diagrama esquemático mostrando a evolução do processo de filtração em gel 23

Figura 2.6. Coluna de afinidade 25

Figura 2.7. Diagrama esquemático mostrando os componentes básicos de um sistema de purificação de macromoléculas biológicas

Figura 3.1. Passos envolvidos na resolução de uma estrutura tridimensional por difração de raios X

Figura 3.2. Fenômeno de salting-in $\quad 40$

Figura 3.3. Contribuição dos efeitos eletrostático e hidrofóbico sobre a solubilidade S 41

Figura 3.4. Descrição esquemática de um diagrama bidimensional da solubilidade de uma macromolécula biológica 44

Figura 3.5. Padrão das linhas de convecção de um fluido 46

Figura 3.6. Gotas de cristalização $\quad 48$

Figura 3.7. Montagem de uma gota de cristalização 50

Figura 4.1. Espalhamento de raios $\mathrm{X}$ por um elétron 57

Figura 4.2. Composição do vetor espalhamento $\mathbf{S}$

Figura 4.3. Posições atômicas em uma cela unitária 59 
Figura 4.4. Diagrama de Argand mostrando a soma vetorial 60

Figura 4.5. Diagrama de Argand ilustrando o espalhamento total de uma molécula 61

Figura 4.6. Diagrama de Argand ilustrando a soma vetorial quando a fase é múltiplo de $2 \pi \quad 62$

Figura 4.7. Esfera de Ewald $\quad 63$

Figura 4.8. Diferença de caminho ótico 66

Figura 5.1. Estrutura dos inibidores de CDK2 estudados nesta tese $\quad 70$

Figura 5.2. Capilar de quartzo $\quad 71$

$\begin{array}{ll}\text { Figura 5.3. Montagem do cristal } & 73\end{array}$

Figura 5.4. Diagrama esquemático de um sistema criogênico 75

Figura 5.5. Sistema criogênico instalado na University of California, Berkeley 76

Figura 5.6. Sistema criogênico instalado em Brookhaven, USA 77

Figura 5.7. Difratômetro R-AXIS II C

Figura 5.8. Ânodo rotatório $\quad 80$

Figura 5.9. Diagrama esquemático do espelho focalizador de raios $X$

Figura 5.10. Colimador de orificio mostrando o ângulo de maior divergência 83

Figura 5.11. Movimento de rotação $\quad 84$

Figura 5.12. Geometria da câmara de oscilação $\quad 86$

Figura 5.13. Porcentagem do espaço recíproco $\quad 88$

Figura 5.14. Espaço reciproco $\quad 89$

Figura 5.15. Sistema R-AXIS IIC 90

Figura 5.16. Perfil de integração das reflexões 99

Figura 6.1. Principais passos do algorítmo de substituição molecular $\quad 110$

Figura 6.2. Refinamento com X-PLOR 116

Figura 6.3. Mapa de densidade eletrônica para CDK2-DFP 117

Figura 6.4. Mapa de densidade eletrônica para CDK2-Roscovitine 119

Figura 6.5. Diagrama topológico da CDK2 121

Figura 6.6a. Estrutura da CDK2-ATP 122

Figura 6.6b. Superficie de acessibilidade ao solvente do complexo CDK2-ATP 123

Figura 6.7. Diferenças conformacionais entre CDK2-ATP e CDK2-ATP Ciclina A 124

$\begin{array}{ll}\text { Figura 6.8. Estrutura do complexo CDK2-Ciclina A } & 125\end{array}$ 
Figura 6.9a. Estrutura do complexo CDK2-DFP 126

Figura 6.9b. Estrutura do complexo CDK2-Roscovitine 127

Figura 6.10a. Bolsão de ligação de ATP $\quad 128$

Figura 6.10b. Superposição das moléculas de ATP e DFP 128

Figura 6.11. Contatos entre CDK2 com ATP (a) e CDK2 com DFP (b) 130

Figura 6.12. Bolsão de ligação de ATP 132

Figura 6.13. Contatos entre CDK2 e Roscovitine 133

Figura 6.14. Superficie de acessibilidade ao solvente para CDK2-Roscovitine 134

Figura 7.1. Superficie de acessibilidade ao solvente para CDK2-DFP (GRASP) 139

Figura 7.2. Superficie de acessibilidade ao solvente para CDK2-Roscovitine(GRASP) $\quad 140$

Figura 7.3. Fórmula molecular dos cinco ligantes $\quad 141$ 


\section{LISTA DE TABELAS}

Tabela 2.1. Trocadores iônicos $\quad 22$

Tabela 2.2. Materiais comumente usados para filtraçâo em gel 24

Tabela 2.3. Lista de tampôes utilizados na purificação da CDK2 31

Tabeia 3.1. Parâmetros que afetam a cristalização de macromoléculas biologicas 34

Tabela 3.2. Parâmetros da matriz de cristalização 49

Tabela 5.1. Programas usados para controle e processamento de dados 91

Tabeia 5.2. Evolução da completeza dos dados do compiexo CDK2-DFP 100

Tabela 5.3. Resumo das informações sobre a coleta de dados 103

Tabeia 6.1. Unidades assimetricas a serem usadas para a procura rotacional 107

Tabela 6.2. Estatistica do refinamento 119

Tabela 7.1. Superficies de acessibilidade ao soivente 138 


\section{LISTA DE ABREVIATURAS}

ATP - Adenosina Tri-fosfato

CAK - CDK activating kinase, quinase ativadora de CDK.

CDC2 - Cell Division Cycle 2, Ciclo de Divisão Celular 2

CDC25 - Cell Division Cycle 25, Ciclo de Divisão Celular 25

CDK2 - Cyclin-Dependent Kinase 2, Quinase Dependente de Ciclina 2

CDK4 - Cyclin-Dependent Kinase 2, Quinase Dependente de Ciclina 4

CDKs - Cyclin-Dependent Kinases, Quinases Dependentes de Ciclina

Cip - Cyclin inhibitory protein, proteina inibidora de ciclina

CKI - CDK Inhibitor, Inibidores de CDKs (Proteinas inibidoras de CDKs)

DFP - Descloro-flavopiridol (inibidor de CDK2)

DNA - Deoxyribonucleic acid, ácido desoxyribonucléico.

INK4 - Inhibitory protein for CDK4, Proteína inibidora de CDK4.

IPA - Isopenteniladenina (inibidor de CDK2)

Kip - Kinase Inhibitory protein, proteina inibidora de quinases

PKA - cyclic AMP-dependent protein kinase, quinase dependente de AMP cíclico, onde AMP é a sigla para Adenosina Monofosfato. 


\section{RESUMO}

O ciclo celular é controlado pela atividade das quinases dependentes de ciclinas ( Ciclindependent kinases, $\mathrm{CDKs}$ ). As $\mathrm{CDKs}$ são inativas como monômeros, e a sua ativação necessita da ligação às ciclinas, uma familia diversa de proteínas cujos os niveis oscilam durante o ciclo celular, $\mathrm{e}$ fosforilação pela CAK ( CDK-activating kinase ) sobre um residuo de treonina específico. As CDKs são capazes de fosforilar muitas proteínas que estão envolvidas nos eventos do ciclo celular, incluindo histonas e proteinas supressoras de tumores como pRb. Além da função de regulação positiva das ciclinas e CAK, muitas proteinas inibidoras de CDKs (CDK inhibitors, CKIs) têm sido descobertas, tais como p16, p21 e p28. Visto que, a desregulação das ciclinas e/ou alteração ou ausência de CKIs têm sido associadas com muitos cânceres, há um forte interesse em inibidores químicos de CDKs que possam ter uma função importante na descoberta de novas familias de agentes anti-tumores.

Visto que, ATP é o autêntico co-fator da CDK2 este pode ser considerado como um "pseudocomposto lider" para a descoberta de inibidores de CDK2. Entretanto, há duas preocupações maiores a serem consideradas: compostos contendo adenina são ligantes comuns para muitas enzimas nas células, desta forma, qualquer derivado de adenina poderá inibir muitas outras enzimas nas células, segundo, qualquer composto altamente carregado como a ATP não será absorvido pelas células.

Nós descrevemos aqui as estruturas determinadas por difração de raios $\mathrm{X}$ da $\mathrm{CDK} 2$ em complexo com dois inibidores diferentes, descloro-flavopiridol(DFP) e Roscovitine. A estrutura do complexo binário CDK2-DFP foi resolvida por substituição molecular e refinada até um $\mathrm{R}_{\text {factor }}=20,3$ $\%$ e a estrutura da CDK2-Roscovitine foi refinada até um $\mathrm{R}_{\text {factor }}=18,0 \%$.

O descloro-flavopiridol é uma flavona com uma nova estrutura, comparável àquelas de flavonas polihidroxiladas. Estudos prévios mostraram que flavopiridol, um flavonóide, pode inibir cânceres de mama e de pulmão. O Roscovitine é um derivado de adenina e um potente inibidor de CDK2. Os dois inibidores são inibidores competitivos contra ATP e se ligam ao bolsão de ligação de ATP da CDK2. A comparação das estruturas tridimensionais de CDK2-DFP e CDK2-Roscovitine com a de CDK2-ATP mostraram que o bolsão hidrofóbico de ligação de adenina tem a abilidade surpreendente de acomodar estruturas moleculares diferentes daquelas da ATP. 


\begin{abstract}
Cell cycle progression is tightly controlled by the activity of ciclin-dependent kinases (CDKs). CDKs are inactive as monomers, and activation requires binding to cyclins, a diverse family of proteins whose levels oscillate during cell cycle, and phosphorilation by CDK-activating kinase (CAK) on a specific threonine residue. CDKs are able to phosphorylate many proteins that are involved in cell cycle events, including histones and tumor suppressor proteins like the retinoblastoma gene product $\mathrm{pRb}$. In addition to the positive regulatory role of cyclins and CAK, many negative regulatory proteins ( CDK Inhibitors, CKIs) have been discovered, such as p16, p21, and p28. Since deregulation of cyclins and/or alteration or absence of CKIs have been associated with many cancers, there is strong interest in chemical inhibitors of CDKs that could play an important role in the discovery of new family of antitumor agents.
\end{abstract}

Since ATP is the authentic cofactor of CDK2 it can be considered as a "pseudo-lead compound" for discovery of CDK2 inhibitors. However there are two major concerns: adenine containing compounds are common ligants for many enzymes in cells, thus, any adenine derivatives may inhibit many enzymes in the cells: second, any highly charged compounds such as ATP will prevent them from uptake by cells.

We report here the $\mathrm{x}$-ray structures of CDK2 in complex with two different inhibitors, deschloro-flavopiridol(DFP) and Roscovitine. The structure of the binary complex CDK2-DFP was solved by molecular replacement and refined to $\mathrm{R}_{\text {factor }}$ of $20.3 \%$ and the structure of CDK2-Roscovitine was refined to $\mathrm{R}_{\text {factor }}=18.0 \%$.

The deschloro-flavopiridol(DFP) is a flavone with a novel structure, compared to that of polyhydroxylated flavones. Previous studies have shown that flavopiridol, a flavonoid, can inhibit growth of breast and lung carcinoma cell lines. The Roscovitine is a adenine derivative and a potent CDK2 inhibitor. The two inhibitors are competitive inhibitors for ATP binding to CDK2 and bind to the ATP binding pocket of CDK2. The comparison of the three-dimensional structures of CDK2-DFP and CDK2-Roscovitine with the CDK2-ATP shows that the hydrophobic adenine-binding pocket has a surprising ability to accommodate molecular structures that are different from ATP. 
"I believe that the study of science, the learning of the scientific method by all people, will ultimately help the people of the world in the solution of our great social and political problems"

Linus Pauling 


\section{CAPÍTULO 1}

\section{BREVE INTRODUÇÃO ÀS BASES MOLECULARES DA PROGRESSÃO DO CICLO CELULAR}

\section{Introdução.}

O objetivo principal deste capítulo é apresentar brevemente algumas das proteínas envolvidas na progressão do ciclo celular, especialmente aquelas envolvidas na transição $\mathrm{G}_{1} / \mathrm{S}_{\text {e }} \mathrm{G}_{2} / \mathrm{M}$. O autor visa, desta forma, destacar a importância das Quinases Dependentes de Ciclina (Cyclin Dependent Kinase) na progressão do ciclo celular e mostrar a motivação biológica que levou ao estudo estrutural das CDKs. Sem a ambição de ser completo e sim de servir como um indicativo da importância destas quinases na progressão do ciclo celular. O enfoque principal do capitulo está sobre o papel chave das CDKs nos processos de transição das fases do ciclo celular $\left(G_{1}\right.$ para $S$ e $G_{2}$ para $\left.M\right)$ e como a inibição destas quinases pode ser uma ferramenta útil na descoberta de novas drogas contra o câncer.

\subsection{Mitose e as fases do ciclo de divisão celular(Voet \& Voet, 1995).}

O ciclo celular é a seqüência de eventos que ocorre durante o tempo de vida da célula eucariótica. Ele é dividido em quatro fases distintas (Fig. 1.1).

1. Fase $G_{1}$ que cobre a maior parte do ciclo celular.

2. Fase S (para sintese) é o período onde ocorre a sintese de DNA (ácido desoxibonucléico).

3. Fase $\mathrm{G}_{2}$, durante esta fase a agora célula tetraplóide com $4 \mathrm{~N}$ cromossomos ${ }^{1}$, se prepara para a mitose, esta fase é relativamente curta em relação às outras fases do ciclo celular.

\footnotetext{
${ }^{1} \mathrm{O}$ número $\mathrm{N}$ representa o número de cromossomos únicos. uma célula diplóide possue $2 \mathrm{~N}$ cromossomos.
}

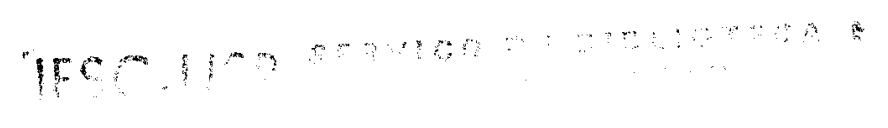


4. Mitose e divisão celular ocorrem no breve periodo da fase $\mathrm{M}$.

A mitose é dividida em prófase, metáfase, anáfase e telófase (Fig. 1.2). A prófase é caracterizada pelo espessamento e encurtamento dos cromossomos, e sua divisão em duas

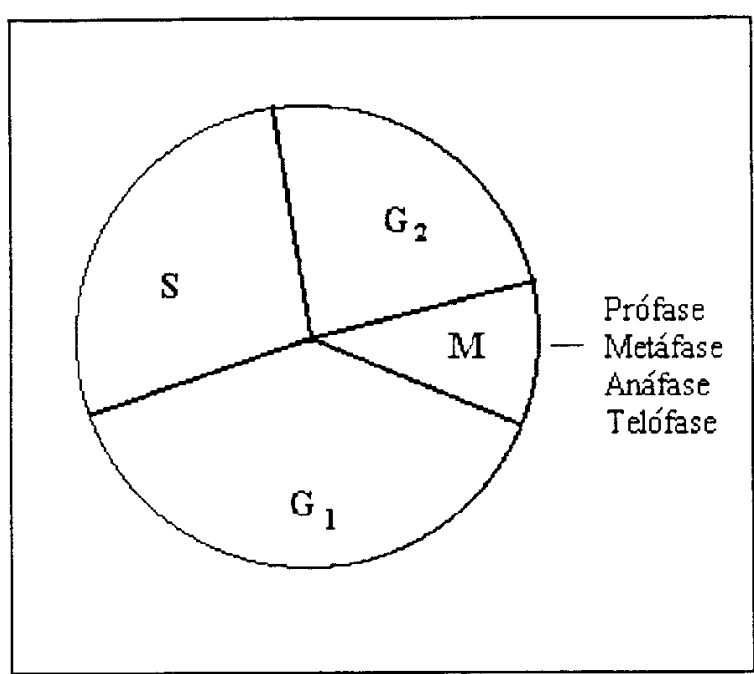

Figura 1.1. As fases do ciclo de divisão celular. cromatides (cada uma delas equivale ao cromossomo original). Na metáfase o centríolo se desloca para cada pólo celular e produz uma rede de fibras fusiformes. $\mathrm{Na}$ anáfase as fribras fusiformes separam as cromatides do equador da célula. Após a separação, as cromatides, agora verdadeiros cromossomos, reúnem-se no interior de um novo núcleo antes que o citoplasma se divida (telófase) e duas novas células sejam formadas. No final temos duas células-filhas diplóides, cada uma com o mesmo número, $2 \mathrm{~N}$, de cromossomos da célula-mãe. O ciclo celular para células em cultura ocupa tipicamente um período de 16 à 24 horas. Contudo, o ciclo celular para células diferentes de um mesmo organismo multicelular pode variar de 8 horas à mais de 100 horas. A maior parte desta variação ocorre na fase $G_{1}$. Além disso, há ainda células que nunca se dividem, tais como os neurônios; estas assumem um estado quiescente conhecido como fase $G_{0}$. 


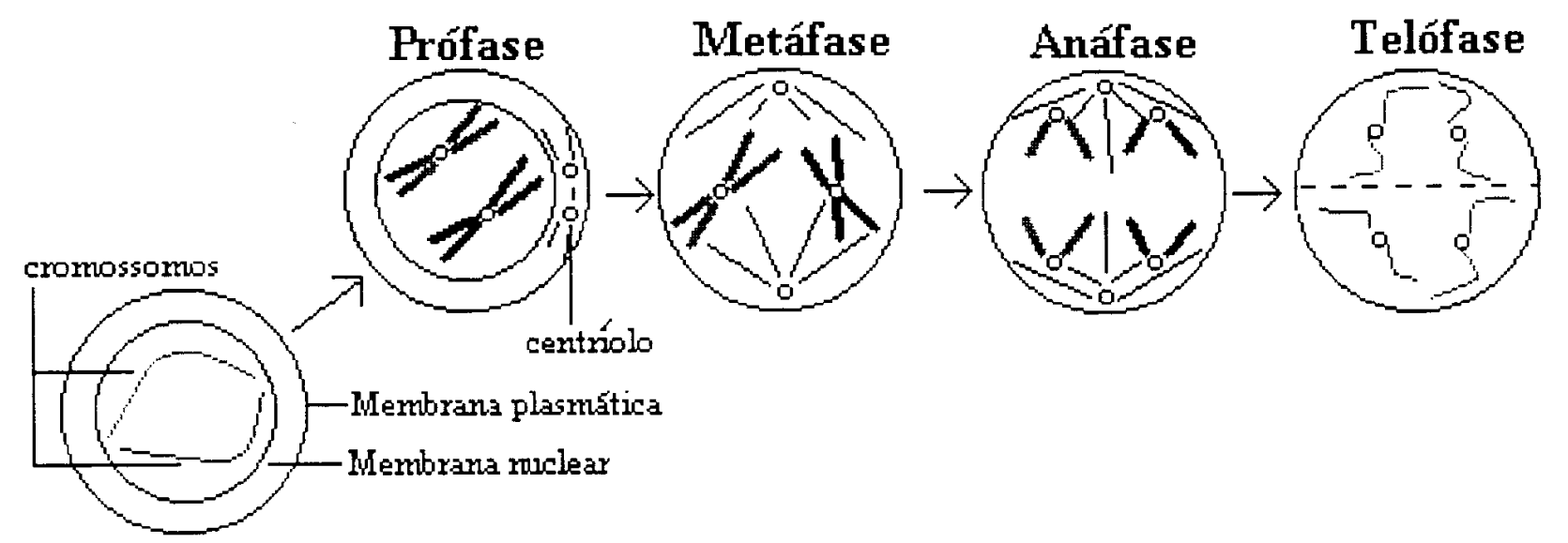

Célula-mãe

Figura 1.2. As fases da mitose.

\subsection{Bases moleculares do câncer (Voet \& Voet, 1995; Murray et al.,1993).}

As células do corpo normalmente permanencem sob desenvolvimento estritamente controlado. Desta forma, durante embriogênesis, as células devem se diferenciar, proliferar, migrar, e mesmo morrer num arranjo espacial preciso e obedecendo a uma seqüência temporal para produzir um organismo normal. Em adultos, as células de certos tecidos, tais como o epitélio intestinal e os tecidos formadores de sangue da medula, continuam a proliferar. Contudo, a maioria das células adultas do corpo permanecem quiescentes, isto é, na fase $G_{0}$ do ciclo celular.

Células ocasionamente perdem o controle de seu desenvolvimento e iniciam uma proliferação excessiva. Os tumores resultantes podem ser de dois tipos:

1. Tumores benignos, tais como verrugas e sinais, estes crescem pela simples expansão e geralmente permanecem encapsulados por uma camada de tecido.

2. Tumores malignos, ou cânceres crescem de uma maneira invasiva e se espalham num processo chamado metástase onde colonizam novos locais no corpo. Tumores malignos são quase que invariavelmete ameaças à vida, e são responsáveis por $20 \%$ das mortes nos Estados Unidos. 
O câncer, como um dos maiores problemas de saúde dos seres humanos, tem recebido uma enorme atenção biomédica nas últimas décadas. Há aproximadamente 100 tipos diferentes de cânceres, estando bem desenvolvidos os métodos para a detecção e tratamento, e a epidemologia do câncer tem sido caracterizada extensivamente. Mas nós estamos só começando a entender as bases moleculares desta coleção de doenças. Como o câncer pode ser considerado como resultante de um ciclo celular anormal, nós discutiremos alguns aspectos da progressão do ciclo celular.

\subsection{Progressão do ciclo celular (De Bondt et al., 1993).}

A progressão do ciclo celular é controlado em dois postos distintos, um anterior à replicação do DNA e outro anterior à mitose, em ambos os pontos o controle é exercido por CDKs (Cyclin-Dependent Kinases) (Fig. 1.3). Estas proteínas são inativas como monômeros e a sua ativação requer a ligação de ciclinas, uma vasta família de proteínas cujo a concentração oscila durante o ciclo celular. O início da replicação é controlado pelo complexo CDK2-Ciclina A, enquanto o início da mitose é controlado pelo complexo CDC2( Cell Division Cycle 2 )-Ciclina B. Além da ação das ciclinas sobre as CDKs, é necessário ainda a fosforilação das CDKs para que as mesmas se tornem ativas e possibilitem a progressão do ciclo celular. A fosforilação acontece sobre o residuo $\mathrm{Thr}$ 160 no caso da CDK2 e sobre Thr 161 no caso da CDC2. Os detalhes moleculares desta ativação serão discutidos adiante. 


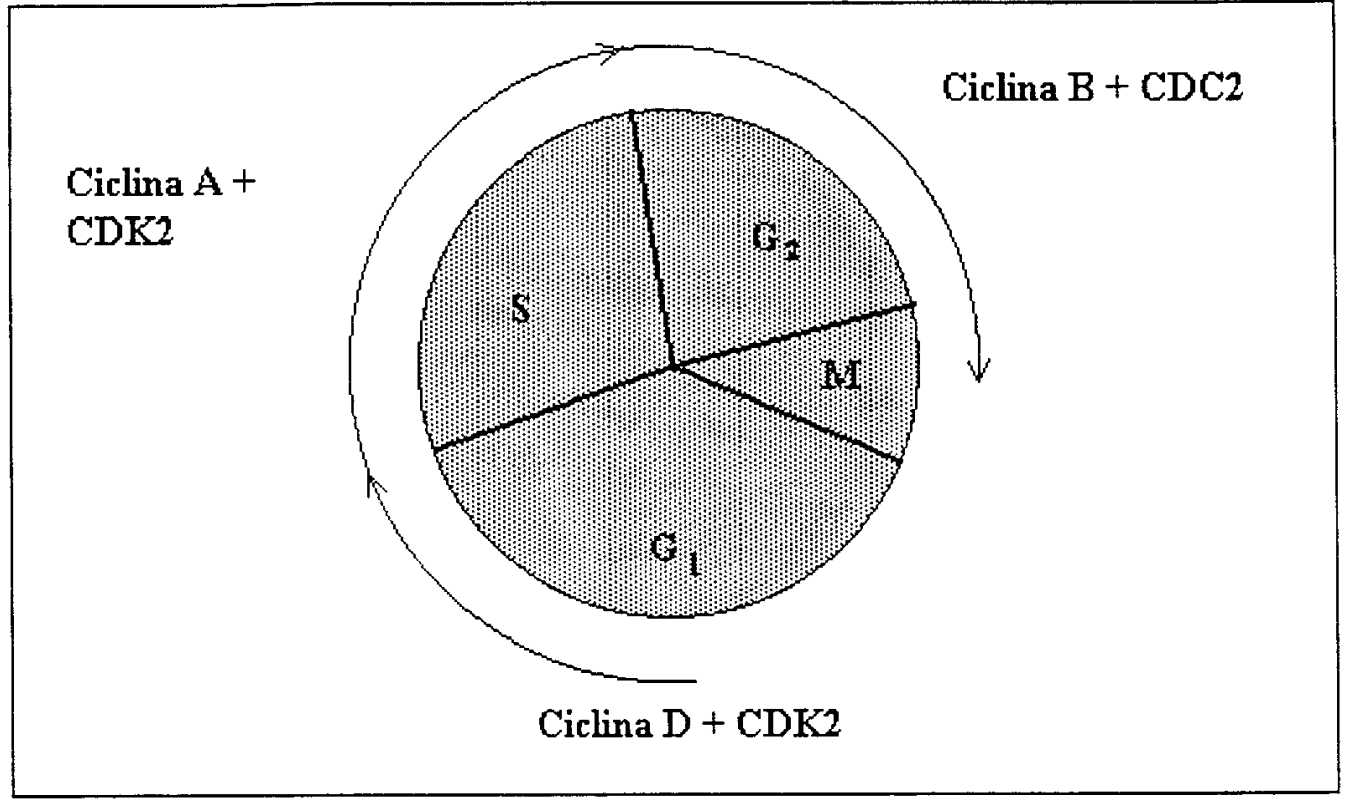

Figura 1.3. Participação das CDKs no ciclo celular.

\subsection{A regulação da divisão celular (Voet \& Voet, 1995; De Bondt et al., 1993).}

Quais são os eventos moleculares que controlam a iniciação da mitose (divisão celular)? As primeiras pistas para a elucidação deste processo vieram dos estudos de embriões de invertebrados marinhos, que revelaram que uma classe de proteínas, chamadas de ciclinas, se acumulavam constantemente por todo o ciclo celular e então desapareciam abruptamente, pouco antes da anáfase da mitose (Fig. 1.2). Embriões de mariscos têm dois tipos de ciclinas, ciclina A e ciclina B, os quais são distinguiveis a partir de suas seqüências de amino ácidos e pelos padrões de acumulação durante o ciclo de divisão celular, ou seja, as ciclinas A e B, se acumulam durante diferente partes do ciclo celular (Fig. 1.3.). Proteinas homólogas a estas ciclinas de mariscos têm sido encontradas em muitos eucariontes, o que não é surpresa, visto que, todas as células eucarióticas seguem o mesmo padrão de ciclo celular (Fig. 1.1. e Fig. 1.2.).

A ciclina A se combina com uma proteina de $34-\mathrm{kD}$ chamada quinase dependente de ciclina 2, CDK2 (Cyclin-Dependent Kinase 2), cuja a seqüência de amino-ácidos indica claramente que se trata de uma proteina da familia das Ser/Thr quinases e que são altamente conservadas de levedura à humano. Estas quinases são os reguladores centrais do ciclo celular. Elas agem fosforilando uma variedade de proteínas nucleares, entre elas histonas $\mathrm{H} 1$, muitas proteinas de oncogenes, e proteinas envolvidas na desmontagem do 
núcleo celular e rearranjo do citoesqueleto. Isto possivelmente inicia uma seqüência de eventos que culmina com a replicação do DNA, no caso das CDK2, e com a mitose no caso da CDC2. Consideraremos estes dois casos independentemente.

A ligação da ciclina A à CDK2 forma um complexo parcialmete ativo, todavia, esta não é suficiente para a ativação completa da CDK2. A proteína CDK2 é uma fosfoproteina também, ou seja, ela necessita ser fosforilada para se tornar ativa. A CDK2 pode ser fosforilada nos resíduos Thr 14, Tyr 15 e Thr 160. Sua ativação é completa somente quando Thr 14 e Tyr 15 estão desfosforiladas e Thr 160 está fosforilada. Os resíduos Thr14, Tyr15 ocupam o bolsão de ligação de ATP ( Adenosina Tri-fosfato) na CDK2, conforme foi identificado na estrutura resolvida por difração de raios X (De Bondt et al., 1993). Um cenário simplificado da participação da CDK2 no ciclo celular (Fig. 1.4.) está descrito a seguir:

1. A célula entra na fase $G_{1}$ do ciclo de divisão celular sem a presença da ciclina $A$ e com CDK2 defosforilada. Uma proteina conhecida com quinase ativadora de CDK, CAK (CDK Activating Kinase) fosforiliza o residuo Thr160 da CDK2.

2. A célula está ainda na fase $G_{1}$ e os resíduos Thr14 e Tyr15 são fosforilados. A recém sintetizada ciclina $\mathrm{A}$ se liga à $\mathrm{CDK} 2$. O resultado é o complexo binário $\mathrm{CDK} 2$-ciclina A triplamente fosforilado. Este complexo é enzimaticamente inativo, pois os residuos Thr14 e Tyr15 evitam à ligação de ATP ao complexo CDK2-ciclina A. Desta forma, o sistema como um todo parece ser desenhado para manter CDK2 inativa enquanto ciclina A se acumula durante a fase $\mathrm{G}_{1}$ do ciclo celular.

3. Uma desfosforilação rápida e específica dos resíduos Thr14 e Tyr15 na fronteira $G_{1} / S$ é executada pela fosfatase CDC25 (Cell Division Cycle 25). Esta desfosforilação inicia a replicação do DNA, a fase $\mathrm{S}$ do ciclo de divisão celular, ou seja, a fosfatase $\mathrm{CDC} 25$ ativa o complexo CDK2-ciclina $\mathrm{A}$.

4. A ciclina A é proteolizada rapidamente num processo mediado por ubiquitina, seguida pela desfosforilação da Thr160 da CDK2. Isto deixa CDK2 inativa, e o ciclo celular está agora na fase $\mathrm{G}_{2}$. 
Estes eventos estão mostrado na figura 1.4. Um processo semelhante ocorre para a mitose:

1. A célula entra na fase $G_{1}$ com ciclina B ausente e a CDC2 (Cell Division Cycle 2) totalmente desfosforilada. Ocorre então a fosforização do resíduo Thr161 da CDC2.

2. A CDC2 é fosforilada também nos resíduos Thr14 e Tyr15 e a recém sintetizada ciclina $\mathrm{B}$ se liga à $\mathrm{CDC} 2$. Este complexo é inativo, e ciclina $\mathrm{B}$ continua a se acumular durante toda a fase $\mathrm{S}$.

3. A desfosforilação dos resíduos $\operatorname{Thr} 14$ e $\operatorname{Tyr} 15$ na fronteira $\mathrm{G}_{2} / \mathrm{M}$ ativa o complexo CDC2-ciclina B e inicia a mitose.

4. A ciclina B é proteolizada e CDC2 é desfosforilada no resíduo Thr161. Isto acaba com a atividade da $\mathrm{CDC} 2$, a célula, agora dividida, retorna à fase $\mathrm{G}_{1}$ do ciclo de divisão celular.

Todos as estapas para a ativação da $\mathrm{CDC} 2$, acima descritas, estão ilustradas na figura 1.5 .

\subsection{As diversas causas do câncer (Voet \& Voet, 1995).}

A maioria dos cânceres são causados por agentes que danificam o DNA ou interferem com sua replicação ou reparo. Estes incluem uma grande variedade de substâncias feitas pelo homem outras que ocorrem normalmente na natureza, conhecidas como substâncias cancerígenas. Outro agente causador de danos ao DNA é radiação que possua energia suficiente para quebrar certas ligações químicas. Por exemplo, quando uma célula é exposta à radiação ultravioleta (200-300nm), como no caso de células epiteliais expostas por longo tempo ao Sol, temos a formação de um anel de ciclobutil entre os resíduos adjacentes de timina na mesma fita de DNA. Tais dimeros de pirimidina distorcem localmente os pares de base da estrutura, de forma que, a replicação e a transcrição ficam comprometidas. Além destes agentes, acima mencionados, temos também vírus que induzem a formação de tumores malignos em seu hospedeiros. 


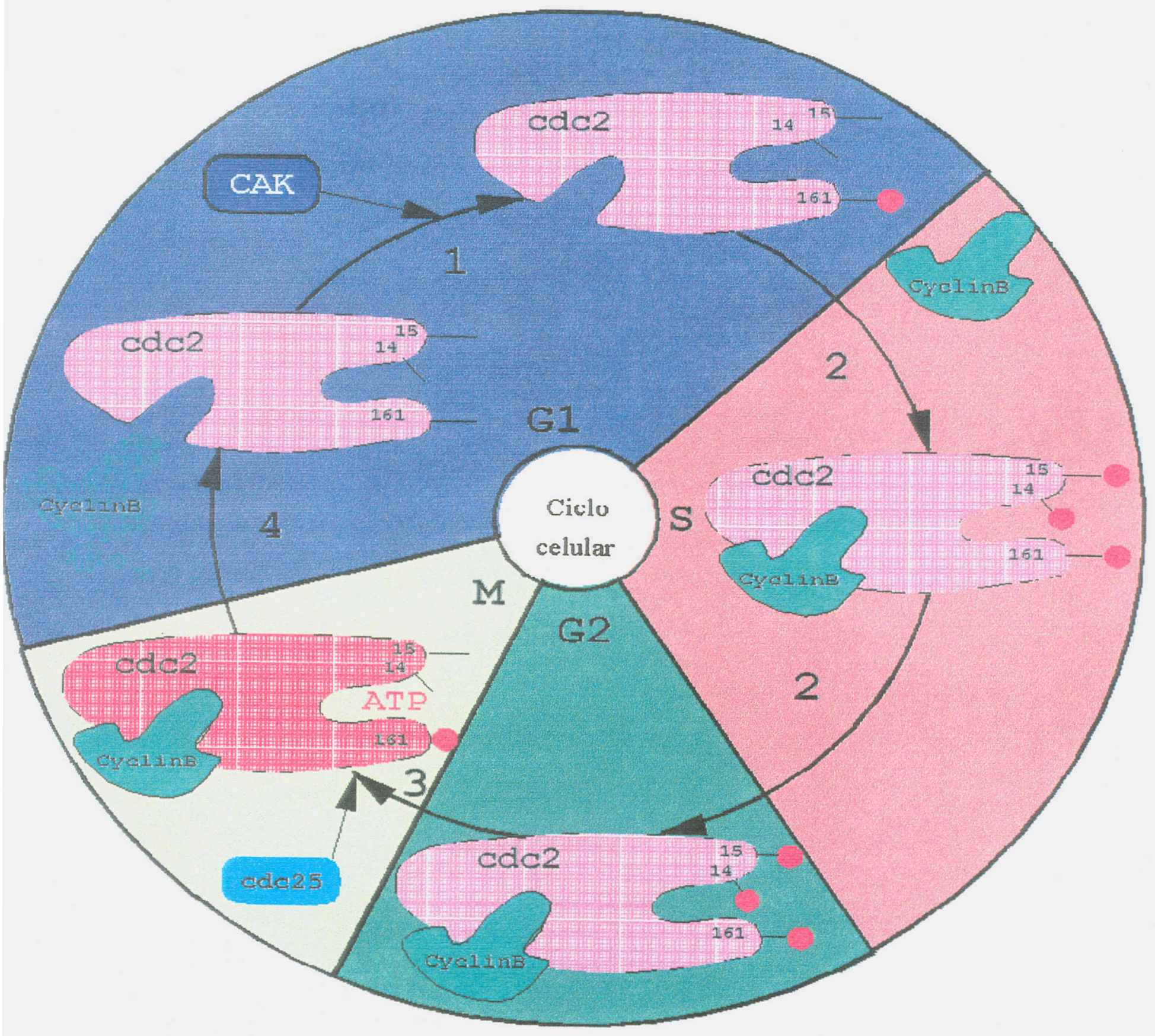

Figura 1.5. Principais etapas na ativação e desativação do complexo CDC2-Ciclina B. 


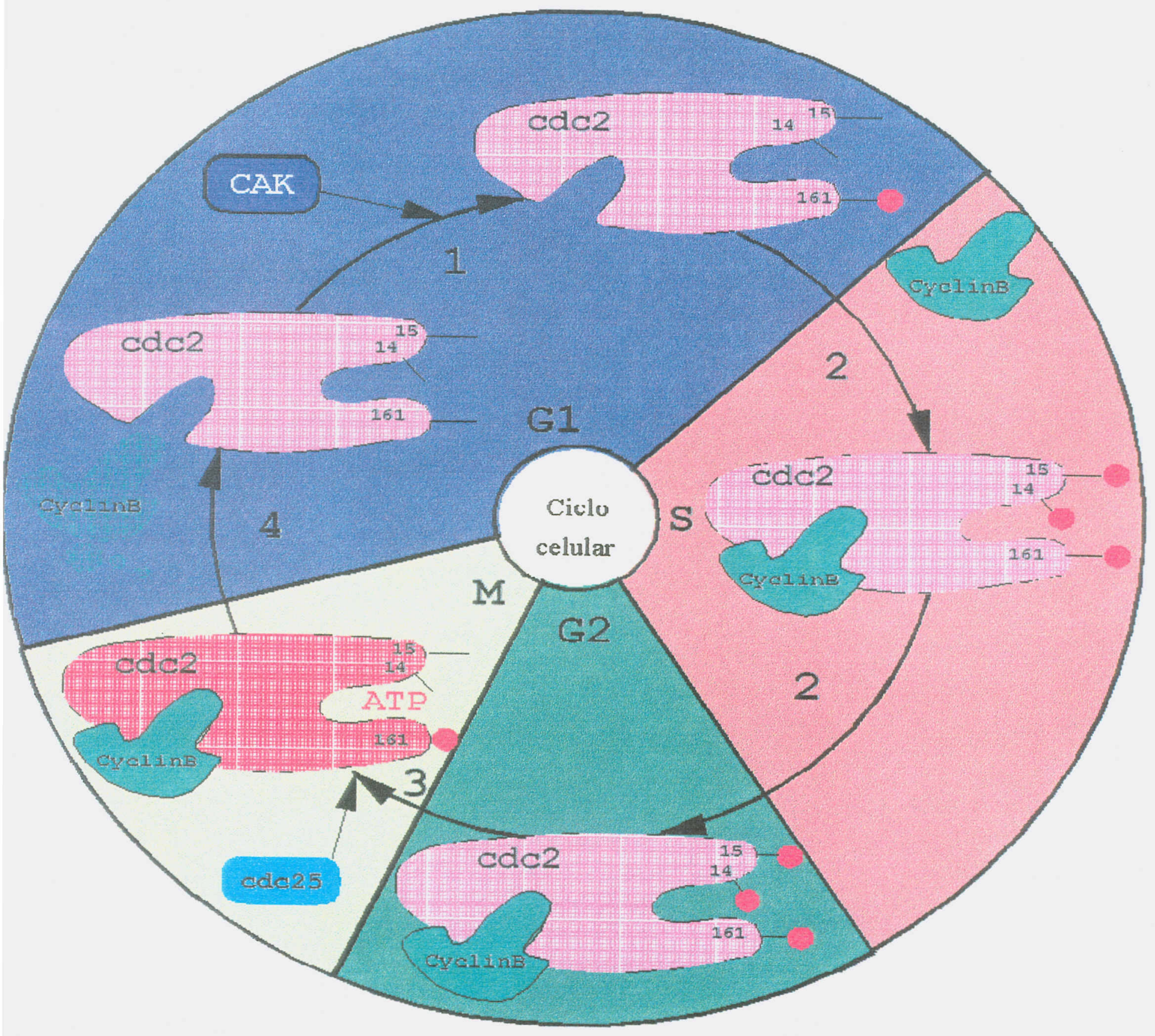

Figura 1.5. Principais etapas na ativação e desativação do complexo CDC2-Ciclina B. 
1.6. p53 o "Guardião do Genoma" (Voet \& Voet, 1995; Cho, et al., 1994).

A idéia que o gene $p 53$ poderia agir como supressor de tumores surgiu primeiramente quando foi descoberto que mutações no gene $p 53$ ocorriam invariavelmente em indivíduos com uma rara doença hereditária conhecida como síndrome de LiFraumeni, que causa uma alta susceptibilidade a uma variedade de tumores malignos, particularmente câncer de seio, que geralmente se desenvolve antes dos 30 anos. O produto deste gene é uma fosfoproteína nuclear de $53-\mathrm{kD}$ e que é encontrada mutada em aproximadamente $50 \%$ dos cânceres humanos.

A fosfoproteína p53 se liga especificamente às fitas duplas de DNA. Experimentos mostraram que a p53 é na verdade um poderoso ativador de transcrição. $\mathrm{Na}$ realidade, todas as formas de p53 com mutações que estão implicadas no câncer, não se ligam ao DNA. Então, por que p53 é um supressor de tumores? A pista vem da observação de que células expostas à radiação ultra-violeta ou às substâncias cancinorgênicas que danificam o DNA induzem a acumulação de p53 normal. A proteína p53 age como um "guardião do genoma", monitorando a integridade do mesmo. Se o genoma está danificado p53 se acumula, e ativa a trancrição do gene, $P i c 1$, cujo produto é uma proteína de $21-\mathrm{kD}$ que se liga e inibe CDKs. Tal inibição da atividade de CDK2, leva a célula a ficar presa na fase $\mathrm{G}_{1}$, o que dá tempo para o reparo do genoma, visto que, a replicação não teve início. Se o reparo do DNA não é bem sucedido, a p53 pode ativar o suicídio da célula, um processo chamado apoptose, com o objetivo de prevenir a proliferação de células com o genoma danificado. Todos estes passos estão ilustrados na figura 1.6. A estrutura resolvida por difração de raios $\mathrm{X}$ do complexo p53-DNA (Cho et al., 1994) mostrou que dois resíduos da proteína p53 que apareciam mutados na maioria dos casos de câncer, os residuos Arg248 e Arg273, estão em contato direto com o DNA, o que explica sua importância, pois estes resíduos são necessários para que a p53 se ligue ao DNA e ative a transcrição da proteína, p21, inibidora de CDK2. 


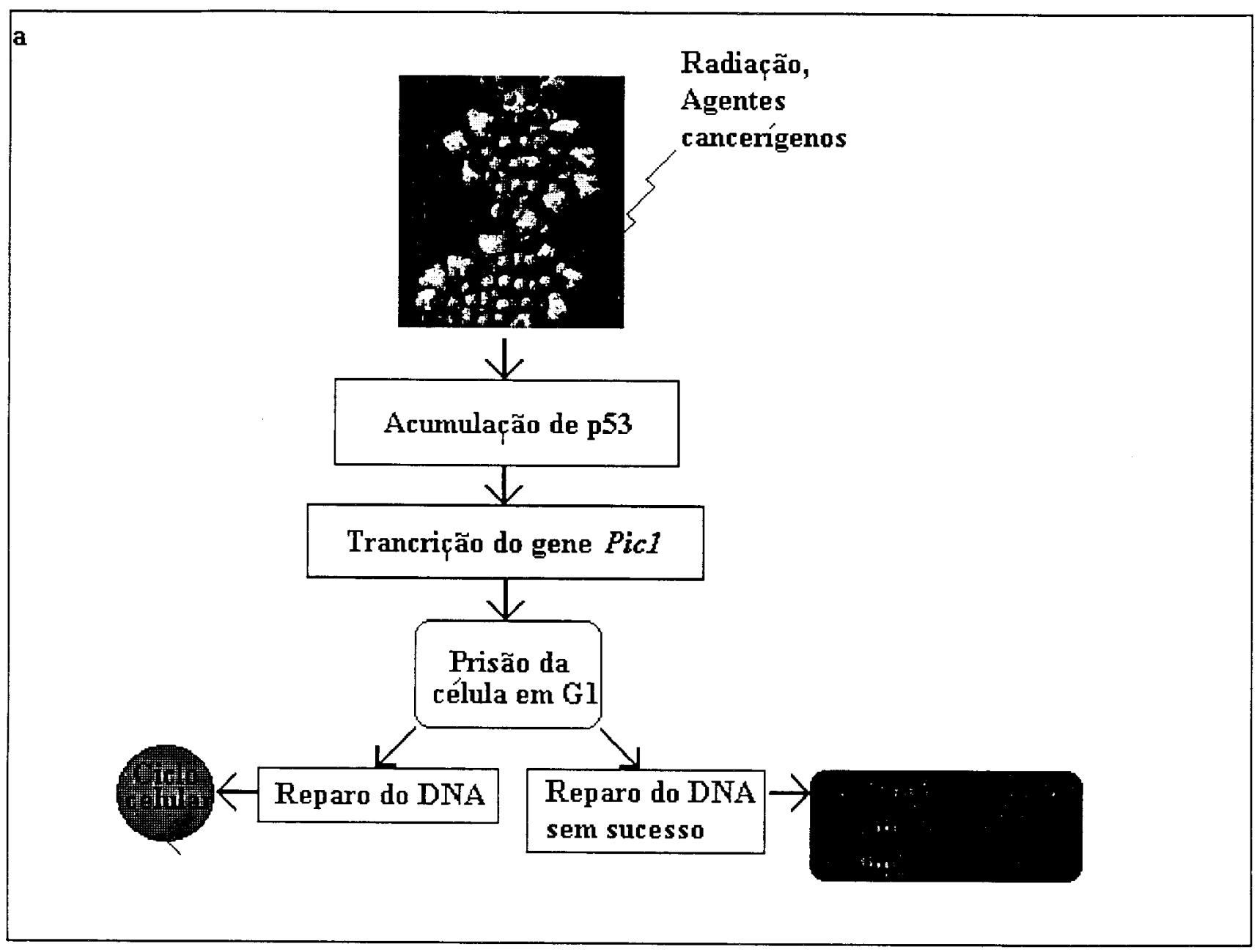

Figura 1.6. Principais passos na ativação e desativação da $p 53$.

Diversas outras proteínas inibidoras de CDKs, além da p21, têm sido identificadas. Estas proteinas podem ser divididas em duas famílias, levando-se em conta as similaridades de seqüência e função. A família das Kip/Cip (Kinase inhibitory protein Cyclin inhibitory protein) que incluen p21 (Harper, J. W. et al., 1993), p27 (Toyoshima \& Hunter, 1994) e p57 (Russo, A. A. et al., 1996), se ligam aos complexos CDK-Ciclina, com preferência por complexos envolvidos na passagem da fase $G_{1}$ para $S$. Estas proteínas inibidoras podem se ligar à CDK ou Ciclina isoladas, mas possuem mais alta afinidade pelos complexos CDK-Ciclina. A outra família denominada INK+ (INhibitory protein for $c d K 4$ ), incluem as proteinas p15, p16, p18 e p19, e inibem CDK4 e uma isoforma, 
chamada CDK6, e também podem ser ligar à CDK e a Ciclina isoladas, ou ao complexo CDK-Ciclina D ( Sherr \& Roberts, 1995).

Os membros da família Kip/Cip contém uma região de 65 amino-ácidos com boa homologia entre eles ( $38-44 \%$ de identidade) no N-terminal, esta região é necessária e suficiente para se ligar e inibir complexos de CDK-Ciclina. Os carboxi-terminais dos membros desta familia de proteína inibidoras não são conservados entre eles (Sherr \& Roberts, 1995).

Visto que, a ausência de uma proteina inibidora de CDKs pode levar à formação de tumores cancerígenos, começou-se a procurar inibidores químicos que pudessem fazer a função inibidora das proteínas p21, p57 etc.. 


\section{CAPÍTULO 2 \\ INTRODUÇÃO AOS MÉTODOS PARA PURIFICAÇÃO DE MACROMOLÉCULAS BIOLÓGICAS}

\subsection{Introdução à purificação de macromoléculas biológicas.}

No estudo estrutural de macromoléculas biológicas uma etapa muito importante anterior à cristalização é a purificação. Sendo que, na maioria das vezes, este processo de purificação da macromolécula tem de ser elaborado e/ou aperfeiçoado, ou simplesmente reproduzido pelo biocristalográfo. Para o estudo estrutural por difração de raios X são necessários muitas vezes, vários miligramas de material puro, o que faz com que o processo de purificação, uma vez otimizado, seja executado repetidamente, para a produção de relativamente grandes quantidades da macromolécula biológica. No meu estudo da CDK2 eu realizei o processo de purificação da mesma proteína dezenas de vezes e após cada preparação tínhamos material para novos experimentos de cristalização. Neste capítulo apresentaremos alguns dos métodos mais utilizados na purificação de proteínas e ácidos nucléicos. Como exemplo de alguns dos métodos discutidos neste capítulo apresentamos o processo de purificação da CDK2 humana.

\subsection{Cromatografia (Voet \& Voet, 1995; Kleinsmith \& Kish, 1995).}

A principal técnica para separação de macromoléculas biológicas é a cromatografia. O termo cromatografia engloba um vasto espectro de procedimentos que separam moléculas baseados nas diferenças dos respectivos modos em que elas se distribuem entre duas fases. O termo cromatografia foi utilizado pela primeira vez em 1903 pelo botânico russo Mikhail Tswett quando este estudava a separação de pigmentos de uma folha vegetal.

Métodos modernos de separação de moléculas presentes em uma mistura baseiamse em procedimentos cromatográficos. Em todos eles uma mistura de substâncias a ser fracionada é dissolvida em um líquido ou gás, conhecido como fase móvel. A solução resultante atravessa uma coluna formada de uma matriz sólida porosa conhecida como fase estacionária, que pode conter um líquido associado à mesma. As interações dos solutos individuais com a fase estacionária agem de forma a afetar a velocidade de 
migração da fase líquida através da matriz de uma forma que varia com as propriedades de cada soluto. Se a mistura que está sendo fracionada é injetada na columa em um banda estreita, ou seja, um volume pequeno em relação ao volume da coluna, as diferentes forças que retardam cada componente da mistura injetada causam uma distribuição das velocidades de migração de cada componente da mistura através da coluna, o que, eventualmente, irá separar a mistura em bandas de substâncias puras.

Os diversos métodos cromatográficos disponiveis são classificados de acordo com as suas fases móvel e estacionária. Por exemplo, na cromatografia gás-líquido as fases móvel e estacionária são gasosa e líquida, respectivamente, enquanto que na cromatografia líquido-líquido as fases são líquidos imiscíveis, um dos quais está ligado a uma matriz sólida inerte. Os métodos cromatográficos podem ainda ser classificados de acordo com a interação dominante entre a fase estacionária e as substâncias que estão sendo separadas. Por exemplo, se a força de retardo é de caracter iônico, a técnica de separação é chamada de cromatografia de troca iônica. Outra técnica cromatográfica baseia-se nas diferentes velocidades de migração através da coluna devido aos diferentes tamanhos das moléculas presentes na mistura e tal técnica é conhecida com cromatografia de filtração em gel. Temos ainda uma técnica que se baseia na afinidade de uma dada macromolécula por um ligante, chamada cromatografia de afinidade. Estas três principais técnicas cromatográficas serão discutidas a seguir

\subsubsection{Cromatografia de troca iônica (Voet \& Voet, 1995; Kleinsmith \& Kish, 1995).}

Macromoléculas biológicas se ligam a trocadores iônicos devido à força eletrostática entre as cargas na superficie da macromolécula e os aglomerados de grupos carregados presentes nos trocadores iônicos. No processo de troca iônica, ions que estão ligados a uma matriz inerte e insolúvel devido à força eletrostática entre eles, são substituidos reversivelmente por ions presentes na solução:

$$
\mathrm{R}^{+} \mathrm{A}^{-}+\mathrm{B}^{-} \leftrightarrow \mathrm{R}^{+} \mathrm{B}^{-}+\mathrm{A}^{-}
$$

onde $\mathrm{R}^{+} \mathrm{A}^{-}$é o trocador aniônico na forma de $\mathrm{A}^{-}$e $\mathrm{B}^{-}$representa ânions em solução. Trocadores catiônicos similarmente possuem grupos carregados negativamente que de 
forma reversivel se ligam a cátions. Poliânions e policátions, por esta razão, se ligam a trocadores aniônico e catiônico, respectivamente. Para ilustrar a troca iônica consideremos, por exemplo, uma macromolécula de carga negativa em sua superficie, esta macromolécula está dissolvida em uma solução que possue íons positivos que se ligam à sua superficie neutralizando-a (figura 2.1a). Uma coluna de troca aniônica foi equilibrada com um tampão que contem ânions que se ligam à matriz da coluna (figura 2.1a). Quando a solução da macromolécula é aplicada à coluna a macromolécula desloca os ânions que estavam acoplados à coluna e ocupa um sítio no interior da matriz sólida da coluna (figura 2.1b). Se agora, que a macromolécula está ligada à coluna, for aplicado um tampão numa concentração salina maior teremos a liberação da macromolécula da coluna.

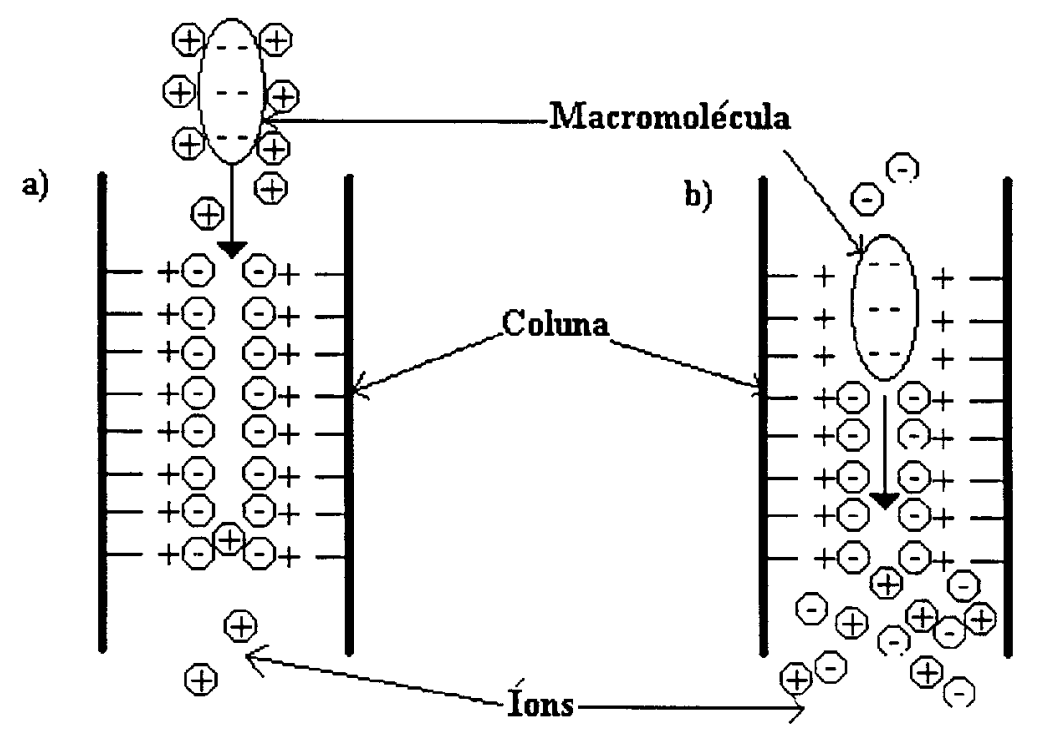

Figura 2.1. Ilustração da troca iônica. a) Macromolécula neutralizada pela ação de íons positivos presentes na solução, b) Macromolécula aprisionada na matriz porosa da coluna de troca aniônica. 


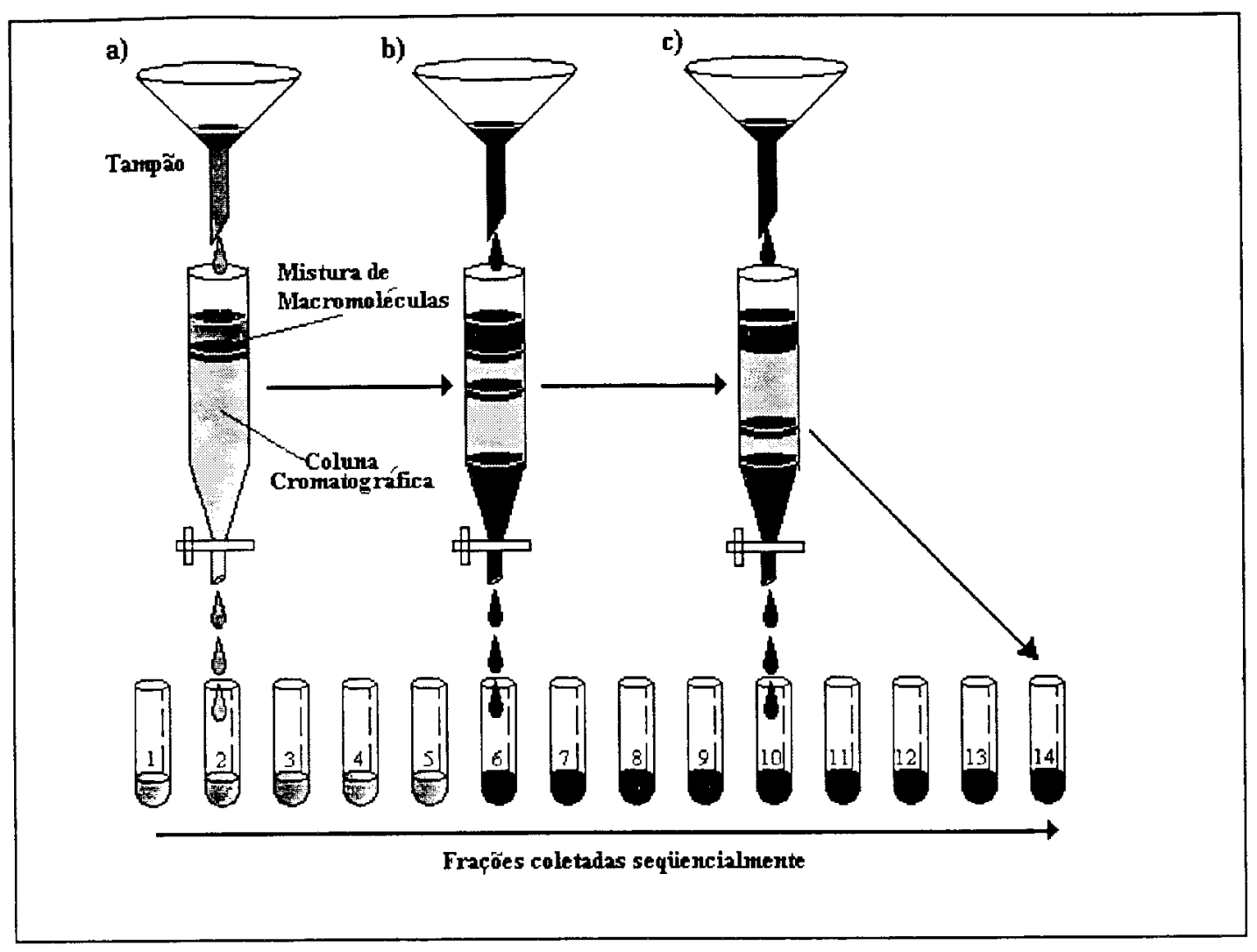

Figura 2.2. Diagrama esquemático ilustrando a separação de uma mistura de macromoléculas biológicas por meio de cromatografia de troca iônica, onde temos uma concentração salina crescente conforme nos movemos da esquerda para a direita, ou seja, a concentração salina do tampão na situação c) é maior que em b) que é maior que em a).

Proteínas e outros polieletrólitos podem possuir cargas positivas e negativas e, desta forma, podem se ligar a ambos tipos de colunas de troca iônica, dependendo de sua carga líquida. A afinidade com a qual um polieletrólito particular se liga a um dado trocador iônico depende do tipo e concentração de todos outros íons presentes na solução, devido à competição entre estes íons por sítios de ligação no trocador iônico. A afinidade de ligação de polieletrólitos que possuem grupos ácido-base é também altamente dependente do $\mathrm{pH}$, por causa da variação da suas cargas líquidas com o $\mathrm{pH}$.

$\mathrm{Na}$ purificação de uma dada macromolécula biológica o $\mathrm{pH}$ e a concentração salina da solução tampão no qual a macromolécula está dissolvida são escolhidos de maneira a imobilizar a macromolécula em um dado tracador iônico. A solução impura da 
macromolécula é aplicada a uma coluna no qual o trocador iônico foi inserido e posteriormente a coluna é lavada com esta solução tampão.

Cada macromolécula biológica se liga ao trocador iônico com afinidades diferentes, ou seja, a distribuição de cargas na superficie das macromoléculas lhes conferem diferentes afinidades por um dado trocador iônico. Assim, conforme a coluna, na qual foi aplicada uma mistura de macromoléculas, é lavada com tampão, um processo conhecido com eluição, temos que aquelas macromoléculas com relativamente baixa afinidade pelo trocador iônico presente na coluna se moverão mais depressa pela coluna do que aquelas que se ligam ao trocador iônico com maior afinidade (figura 2.2). Isto ocorre porque o progresso de uma dada macromolécula através da coluna é retardado em relação ao solvente devido às interações entre as macromoléculas e o trocador iônico. Desta forma, as macromoléculas que se ligam com maior afinidade ao trocador iônico podem ser eluídas mudando-se o tampão para um com mais alta concentração salina (e/ou um $\mathrm{pH}$ diferente), um processo conhecido por eluição por passos. Com o uso de um coletor de frações a purificação de uma dada macromolécula pode ser efetuada por meio da seleção da frações com a macromolécula desejada.

O processo de purificação pode ser melhorado usando o método de eluição por gradiente. Neste método a concentração salina e/ou pH é modificado continuamente conforme a coluna é eluída de forma a liberar sequencialmente as várias macromoléculas que estão ligadas à coluna. Diversos tipos de gradientes tem sido aplicados com sucesso na purificação de macromoléculas biológicas, sendo mais usado o gradiente linear, no qual a concentração salina varia linearmente com o volume da solução liberada. Um dipositivo simples para gerar tal gradiente está ilustrado na figura 2.3. Com este dispositivo temos que a concentração da solução que está saindo da câmara de mistura, c, é dada por,

$$
c=c_{2}-\left(c_{2}-c_{1}\right) f
$$

onde $c_{1}$ é a concentração inicial na câmara de mistura, $c_{2}$ é a concentração na câmara do reservatório e f é a fração restante do volume total das soluções presentes no início em ambas as câmaras, ou seja, no final do experimento $f$ tende a zero e a concentração c tende a $c_{2}$. Gradientes lineares são os mais comuns, entretanto outros tipos de gradientes 
podem ser gerados usando duas ou mais câmaras com formas diferentes, ou ainda, usando-se dipositivos programáveis.

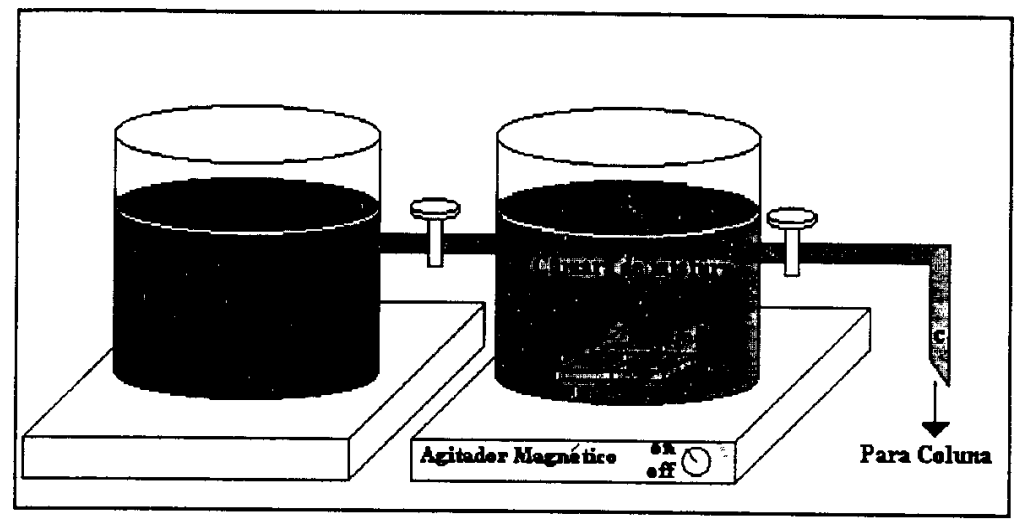

Figura 2.3. Misturador de gradiente, usado para gerar gradientes lineares.

Trocadores iônicos consistem de grupos carregados covalentemente ligados a uma matriz de suporte. A natureza química dos grupos carregados determinam o tipo de íons que podem se ligar ao trocador iônico e a força com a qual eles se ligam. As propriedades químicas e mecânicas da matriz de suporte determinam as características do fluxo, a acessibilidade iônica e a estabilidade do trocador iônico.

Muitas classes de materiais, conhecidos como resinas, são usadas como matrizes de suporte para cromatografia de troca iônica. Entre estes materiais temos celulose e alguns géis. A tabela 2.1 mostra alguns dos trocadores iônicos mais usados.

Os trocadores aniônicos mais comumente usados são o dietil aminoetil- (DEAE-), o hidroxipropil dietil aminoetil- (quaternário) Q- e o trimetil aminoetil- (TMAE-), estes grupos se acoplam diretamente ao grupo hidroxila da matriz. Trocadores catiônicos são divididos em três categorias: fracos, com carboximetils (CM-); fortes, com grupos sulfonados (S- e SP-), e fosfatos. Este último, embora aja como trocador cationnico, também possue ação de afinidade, pois pode interagir especificamente com ácidos nucléicos e com enzimas que se ligam a fosfatos (figura 2.4).

Os trocadores iônicos do tipo gel podem ter os mesmos grupos carregados usados com celulose. A vantagem dos trocadores do tipo gel é que eles combinam as 
propriedades de separação da filtração em gel (seção 2.2.2) com aquelas dos trocadores iônicos.

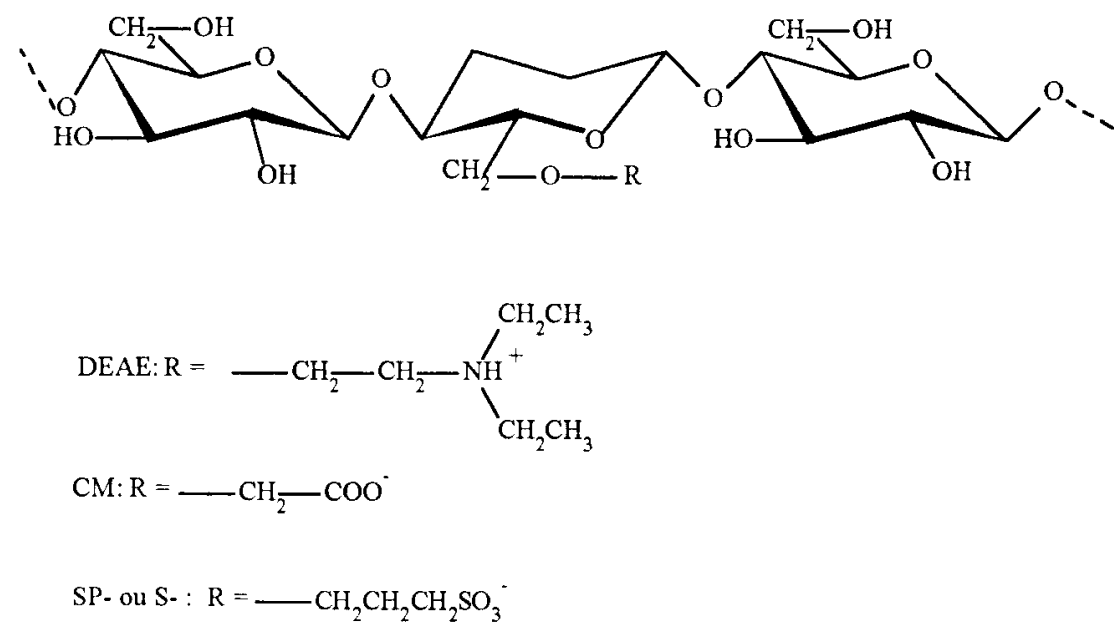

Figura 2.4. Fórmula química dos trocadores iônicos baseados em celulose.

Tabela 2.1. Alguns dos trocadores iônicos mais usados na purificação de macromoléculas biológicas.

\begin{tabular}{|c|c|c|c|}
\hline Nome & Tipo & Grupo ionizável & Uso \\
\hline DEAE-Celulose & Básico & Dietil aminoetil & $\begin{array}{l}\text { Usada na separação de } \\
\text { proteinas ácidas e neutras bem } \\
\text { como ácidos nucléicos. }\end{array}$ \\
\hline CM-Celulose & Ácido & Carboximetil & $\begin{array}{l}\text { Usada na separação de } \\
\text { proteinas básicas e neutras. }\end{array}$ \\
\hline P-Celulose & Ácido & $-\mathrm{PO}_{3} \mathrm{H}_{2}$ & Usada para proteinas básicas. \\
\hline DEAE-Sephadex & Básico & Dietil aminoetil & $\begin{array}{l}\text { Usada na separação de } \\
\text { proteinas ácidas e neutras bem } \\
\text { como ácidos nucléicos. }\end{array}$ \\
\hline CM-Sephadex & Ácido & Carboximetil & $\begin{array}{l}\text { Usada na separação de } \\
\text { proteinas básicas e neutras. }\end{array}$ \\
\hline Bio-Gel CM 100 & Ácido & Carboximetil & $\begin{array}{l}\text { Usada na separação de } \\
\text { proteinas básicas e neutras. }\end{array}$ \\
\hline
\end{tabular}




\subsubsection{Filtração em gel (Voet \& Voet, 1995; Kleinsmith \& Kish, 1995).}

$\mathrm{Na}$ cromatografia de filtração em gel, que é também chamada de peneira molecular, as moléculas são separadas de acordo com o seu tamanho e forma. A fase estacionária nesta técnica é composta de contas poliméricas ou de vidro que contém poros de dimensões moleculares. As moléculas maiores que não conseguem penetrar nos poros fluem mais rapidamente pela coluna do que as moléculas menores que passam pelos poros e são retardadas temporariamente (figura 2.5). A massa molecular da menor molécula que não penetra nos poros das contas de um dado gel é chamado de limite de exclusão do gel. Este parâmetro é, de certa forma, dependente da forma da molécula, visto que uma molécula alongada possue uma chance menor de entrar em um dado poro do que uma molécula esférica com o mesmo volume.

a)

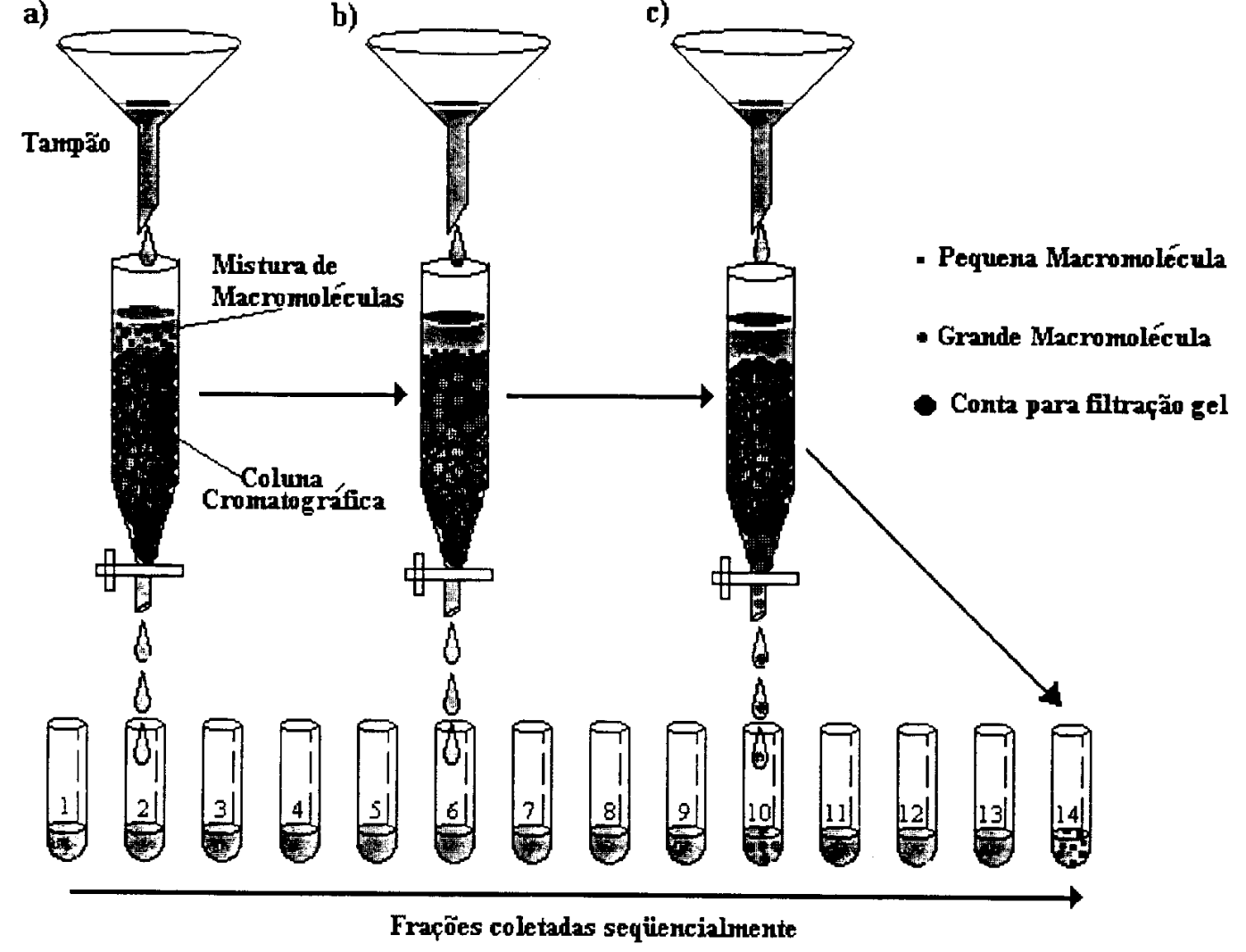

Figura 2.5. Diagrama esquemático mostrando a evolução do processo de filtração gel.

O comportamento de uma molécula em uma coluna de filtração em gel particular pode ser caracterizado quantitativamente. Seja $V_{x}$ o volume ocupado pelas contas, $V_{0} o$ 
volume do solvente que cercam as contas (volume nulo) e $V_{t}$ o volume total da coluna, que é a soma de $\mathrm{V}_{\mathrm{x}} \operatorname{com} \mathrm{V}_{\mathrm{o}}$. Temos que $\mathrm{V}_{\mathrm{o}}$ é tipicamente de aproximadamente $35 \%$ de $\mathrm{V}_{\mathrm{t}}$. $\mathrm{O}$ volume de eluição de um dado soluto, $\mathrm{V}_{\mathrm{e}}$, é o volume do solvente necessário para eluir o soluto da coluna após o mesmo ter entrado em contato com o gel. O volume nulo de uma coluna pode ser medido facilmente tomando-se o volume de eluição de um soluto cuja massa molecular é maior que o limite de exclusão do gel. O comportamento de um soluto particular em um dado gel é portanto caracterizado pela relação $V_{\mathrm{e}} / \mathrm{V}_{\mathrm{o}}$, o volume de eluição relativo, uma quantidade que é independente do tamanho da coluna usada. A maioria dos materiais mais usados como géis cromatográficos são o dextran ( um polímero de glucose produzido pela bactéria Leuconostoc mesenteroides), agarose ( um polímero que alterna D-galactose e 3,6-anidro-L-galactose de algas vermelhas) e poliacrilamida (tabela 2.2.). A agarose na forma comercial de Sepharose é também comumente usada em colunas de troca iônica (DEAE-Sepharose e S-Sepharose).

Tabela 2.2. Alguns dos materiais comumente usados para filtração gel.

\begin{tabular}{lll}
\hline Nome & Tipo & $\begin{array}{l}\text { Faixa do limite de exclusão } \\
\text { (kD) }\end{array}$ \\
Sephadex G-10 & Dextran & $0,05-0,70$ \\
Sephadex G-25 & Dextran & $1-5$ \\
Sephadex G-50 & Dextran & $1-30$ \\
Sephadex G-100 & Dextran & $4-150$ \\
Sephadex G-200 & Dextran & $5-600$ \\
Bio-Gel P-2 & Poliacrilamida & $0.1-1.8$ \\
Bio-Gel P-6 & Poliacrilamida & $1-6$ \\
Bio-Gel P-10 & Poliacrilamida & $1.5-20$ \\
Bio-Gel P-30 & Poliacrilamida & $2.4-40$ \\
Bio-Gel P-100 & Poliacrilamida & $5-100$ \\
Bio-Gel P-300 & Poliacrilamida & $60-400$ \\
Sepharose 6B & Agarose & $10-4000$ \\
Sepharose 4B & Agarose & $60-20000$ \\
Sepharose 2B & Agarose & $70-40000$ \\
& & \\
\hline
\end{tabular}

\subsubsection{Cromatografia de afinidade (Lodish et al., 1995, Kleinsmith \& Kish, 1995b).}


Um terceiro tipo de coluna de cromatografia, chamada coluna de afinidade, baseiase na abilidade de uma molécula se ligar especificamente a uma outra molécula. Este procedimento é um dos tipos mais seletivos de cromatografia, pois utiliza uma matriz com grupos químicos que se ligam especificamente à molécula que se deseja purificar. Devido a sua seletividade a cromatografia de afinidade pode ser usada para purificar proteínas presentes em uma mistura complexa de moléculas. Nesta técnica, uma molécula conhecida como ligante, que se liga especificamente à molécula que se deseja isolar, é covalentemente ligada a uma matriz inerte e porosa tal como agarose.

a)

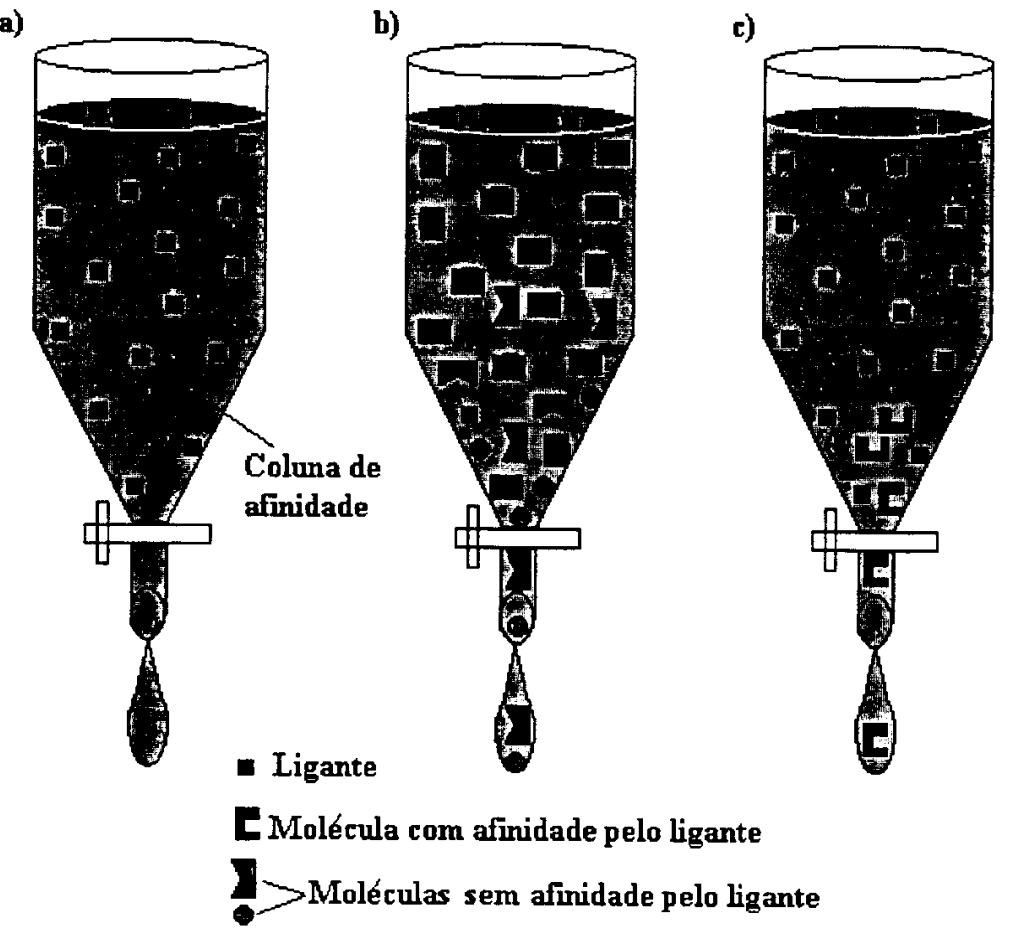

Figura 2.6. Coluna de afinidade. a) Coluna com ligante, b) uma solução contendo três moléculas diferentes são inseridas na coluna, as moléculas sem afinidade pelo ligante são eluídas, c) uma mudança no tampão libera a molécula acoplada ao ligante.

Quando uma solução impura de moléculas é injetada na coluna, a molécula que se deseja purificar se prende ao ligante, enquanto outras moléculas que não possuem especificidade pelo ligante imobilizado na coluna são eluídos com o tampão. A molécula a 
ser purificada pode então ser recuperada numa forma altamente purificada mudando-se as condições de eluição de forma que a molécula seja liberada da coluna. A mudança nas condições de eluição pode ser dar por meio de mudança de $\mathrm{pH}$, concentração salina ou saturação de ligante (figura 2.6). A grande vantagem da cromatografia de afinidade é que nesta técnica se exploram as propriedades bioquímicas únicas da molécula que se deseja purificar ao invés de explorar as pequenas diferenças físico-químicas entre as moléculas que as outras técnicas se utilizam.

\subsection{Cromatografia líquida de alto desempenho (Kleinsmith \& Kish, 1995).}

A maioria dos tipos de coluna de cromatografia são lentas, devido ao tempo que os fluidos levam para passar pela matriz da coluna. Além da incoveniência este atraso prejudica a resolução, pois permite que as moléculas que estão sendo purificadas se espalhem pela coluna durante o processo de purificação. Na cromatografia líquida de alto desempenho (High-performace liquid chromatography, HPLC) bombas de alta pressão são usadas para forçar o fluido através da coluna numa vazão bem maior do que as usadas na cromatografia convencional. Este processo requer o uso de colunas metálicas e matrizes especiais. Usando tal sistema, separações que tomariam horas podem ser realizadas em minutos e com uma resolução melhor. Contudo o uso de bombas e controladores de alta pressão elevam o preço de tais sistemas.

\subsection{Sistema Convencional para Purificação de Macromoléculas Biológicas.}

Para o uso das colunas cromatográficas discutidas na seção 2.2 se faz necessária a montagem de um sistema que possibilite a injeção controlada da mistura de macromoléculas a ser purificada, bem como a deteção e coleta das mesmas. Um sistema com os componentes básicos para o procedimento de purificação está ilustrado na figura 2.7. Neste sistema temos o misturador de gradiente, a bomba peristáltica, a coluna, o detetor de Ultravioleta (UV), o registrador e o coletor de frações. O misturador de gradiente e a coluna já foram discutidos. A bomba peristáltica permite controlar o fluxo de entrada na coluna. Este tipo de bomba normalmente dispõe de um seletor de fluxo que permite ao usuário definir a vazão com que se deseja que a amostra seja injetada na 
coluna. O detetor de UV junto com o registrador permitem ao usuário acompanhar a evolução do processo de purificação. Medindo-se, por exemplo, a variação absorbância de radiação UV no comprimento de onda de $280 \mathrm{~nm}$ com o tempo, pode-se monitorar a eluição da proteína que esta sendo purificada. $O$ coletor de frações pode ser calibrado de forma a coletar em diferentes tubos as diferentes macromoléculas presentes na mistura injetada.

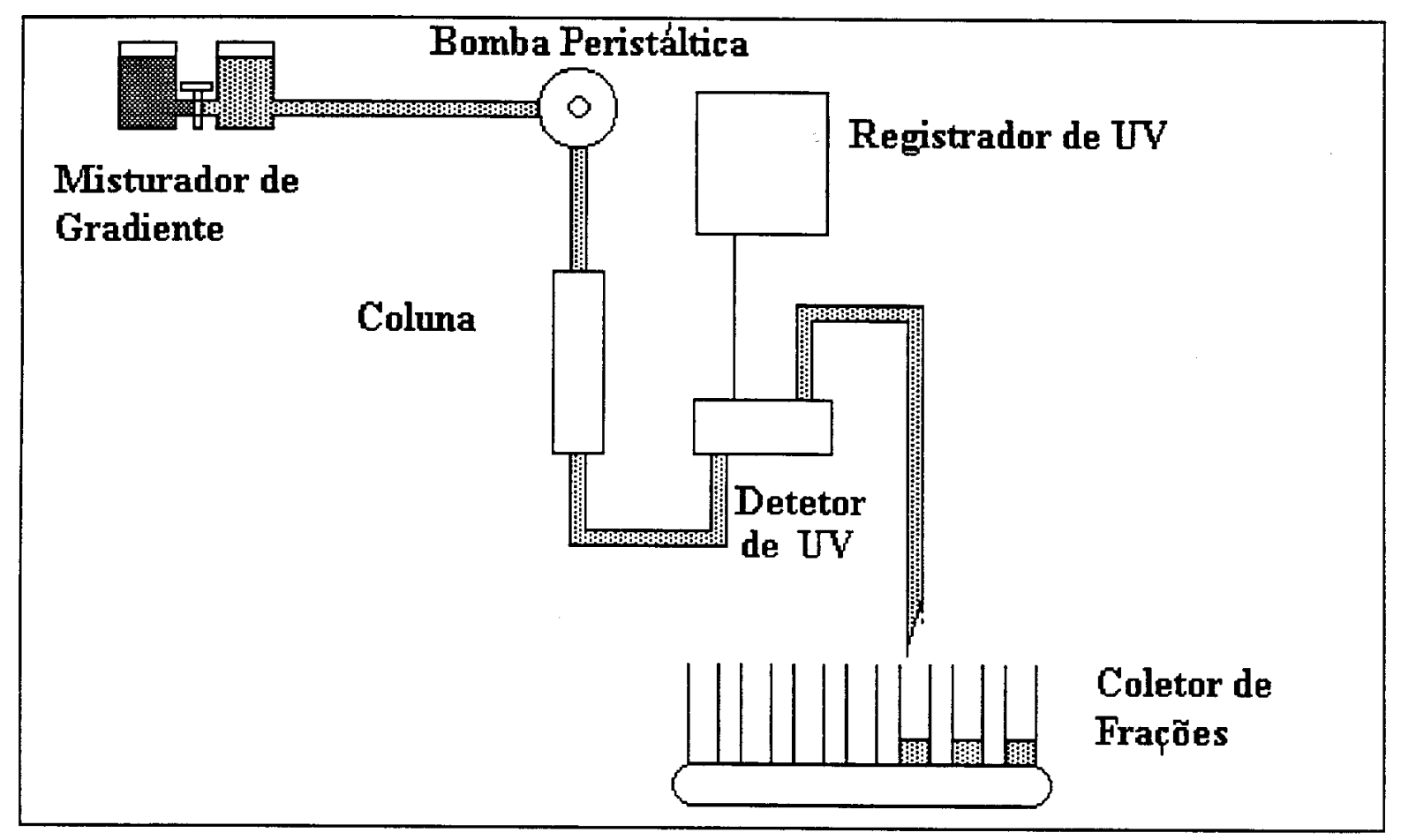

Figura 2.7. Diagrama esquemático mostrando os componentes básicos de um sistema para purificação de macromoléculas biológicas.

2.5. Determinação espectrofotométrica das quantidades de proteínas e ácidos nuclẻicos.

Ao final do processo de purificação de uma macromolécula biológica se faz necessário medir a quantidade de material obtido, para isto, pode-se usar métodos espectrofotométricos. Para se aplicar este método é necessário o conhecimento do coeficiente de extinção (E) da macromolécula. No caso de proteínas, o coeficiente de 
extinção molar teórico (absortividade molar) é dado pelo conteúdo de triptofano e tirosina usando-se a seguinte expressão:

$$
\varepsilon_{280 \mathrm{~nm}}=5690 \mathrm{n}_{\mathrm{x}}+1280 \mathrm{n}_{\mathrm{y}}
$$

onde $\mathrm{n}_{\mathrm{x}}$ é o número de triptofanos e $\mathrm{n}_{\mathrm{y}} \mathrm{o}$ número de tirosinas presentes na cadeia polipeptídica. Desta forma, a concentração (c ) de uma proteína de massa molecular conhecida, $\mathrm{M}_{\mathrm{r}}$, pode ser obtida a partir de:

$$
\mathrm{c}(\mathrm{mg} / \mathrm{ml})=\mathrm{A}_{280 \mathrm{~nm}} \times \mathrm{M}_{\mathrm{r}} / \varepsilon_{280 \mathrm{~nm}}
$$

onde $\mathrm{A}_{280 \mathrm{~nm}}$ é a absorbância de radiação de comprimento de onda de $280 \mathrm{~nm}$ da amostra para um caminho ótico de $1 \mathrm{~cm}$ (Tinoco, Sauer \& Wang, 1995).

Para quantificar a quantidade de DNA ou RNA as leituras devem ser efetuadas em comprimentos de onda de $260 \mathrm{~nm}$. As leituras em $260 \mathrm{~nm}$ permitem o cálculo da concentração de ácido nucléico presente numa amostra pura. Com um caminho ótico de $1 \mathrm{~cm}$ uma absorbância de 1 corresponde a aproximadamente $50 \mu \mathrm{g} / \mathrm{ml}$ de DNA duplo ou $40 \mu \mathrm{m} / \mathrm{ml}$ de RNA.

\subsection{Eletroforeses (Kleinsmith \& Kish, 1995).}

A Eletroforesis em gel é o meio mais usado para se visualizar o conteúdo macromolecular de uma amostra. Eletroforesis é um grupo de técnicas relacionadas que utilizam um campo elétrico para separar moléculas eletricamente carregadas. A amostra que está sendo analisada é colocado na parte de cima de um gel e uma voltagem é aplicada para induzir a migração das moléculas carregadas. As moléculas movem-se através do gel com velocidades que dependem da carga e tamanho da molécula. As bandas resultantes do material são então visualizadas por técnicas de coloração.

A eletroforeses de DNA e RNA é realizada com géis feitos de poliacrilamida ou agarose. Ambos contêm poros através dos quais as moléculas de ácidos nucléicos passam durante a eletroforeses. Visto que, todos os ácidos nuclëicos são contruídos a partir de nucleotídeos que contêm grupos fosfato negativamente carregados, as diferenças em carga 
elétrica não são importantes na determinação do comportamento de ácidos nucléicos durante a eletroforeses. Entretanto, ácidos nucléicos diferem em tamanho, e esta diferença influencia a maneira pela qual eles se movem através dos poros do gel. As moléculas maiores são retardadas, conforme elas passam através dos poros pequenos do gel e desta forma os ácidos nucléicos maiores movem-se mais devagar que os ácidos nucléicos menores durante a eletroforeses. O resultado é que a eletroforeses em gel separa ácidos nucléicos de acordo com a diferença em tamanho, com o menor ácido nucléico se movendo mais rápido em direção à parte inferior do gel.

Ácidos nucléicos que foram fracionados por eletroforesis em gel podem ser visualizados de diversas formas. Se o ácido nucléico é marcado com isótopos radioativos, uma autorradiografia é feita colocando-se um filme sensível a raios X sobre o gel para se localizar as bandas radioativas. Géis contendo DNA podem também ser coloridos usandose usando-se substâncias fluorescentes que fluorescem intensamente quando expostas a radiação UV.

Ao contrário de ácidos nuclécicos, a carga elétrica das proteínas variam significantemente de proteína para proteína e a eletroforeses é por esta razão influenciada por diferenças em carga e tamanho. Entretanto, uma técnica de uso geral chamada eletroforeses em gel de SDS poliacrilamida permite que proteínas sejam separadas basedas somente em seus tamanhos (massas moleculares), como ocorre com ácidos nucléicos. Nesta técnica as proteínas são primeiro tratadas com SDS, um ânion que envolve a superficie da proteina. Isto dissocia as proteinas em suas cadeias polipeptídicas. A alta carga negativa das moléculas de SDS ligadas à proteína mascaram qualquer carga inerente da proteína. Desta forma, todas as proteinas possuem a mesma relação carga/massa, e o único parâmetro que influencia a mobilidade eletroforética é o tamanho da proteína (massa molecular). Como no caso dos ácidos nucléicos, as proteínas menores se movem mais depressa através dos poros do gel de poliacrilamida durante a eletroforeses. Temos, desta forma, uma separação baseada em diferenças de tamanho (massa molecular) das proteinas.

As misturas de proteínas que foram fracionadas por eletroforeses em gel podem ser visualizadas por coloração com prata ou com um corante, o azul Coomassie, ou ainda por autorradiografia, se as proteínas são marcadas radioativamente. 


\subsection{Purificação da CDK2.}

Para ilustrar algumas das principais técnicas utilizadas na purificação de macromoléculas biológicas, que foram discutidas neste capítulo, apresentaremos o protocolo resumido de purificação da CDK2, aos interessados nos detalhes da purificação da CDK2 indica-se a referência Rosenblatt et al, 1993. Apresentaremos os tampões e colunas utilizados e em seguida o procedimento para purificação. O material a ser purificado é o extrato obtido após a quebra e ultracentrifugação das células de inseto Sf9 que foram infetadas com baculovírus contendo o gene da CDK2. Na purificação da CDK2 são utilizadas três colunas, sendo duas de troca iônica, a DEAE-Sepharose $(2,5 \times 5 \mathrm{~cm}$; $25 \mathrm{ml})$ e a S-Sepharose $(2,5 \mathrm{~cm} \times 1,5 \mathrm{~cm} ; 7,4 \mathrm{ml})$ e uma de afinidade a ATP-Agarose (1x2,5cm; 2ml, Sigma A-2767), as dimensões de cada coluna estão entre parênteses após o nome da mesma. Os tampões utilizados estão listados na tabela 2.3.

Para se equilibrar as duas colunas de troca iônica (DEAE-Sepharose e SSepharose) injeta-se o tampão HN1000E (aproximadamente $30 \mathrm{ml}$ ) em ambas colunas e após injeta-se $30 \mathrm{ml}$ de tampão $\mathrm{HN} 25 \mathrm{E}$ na coluna DEAE-Sepharose e $30 \mathrm{ml}$ de tampão HN50E na coluna S-Sepharose. A vazão durante este processo de equilíbrio deve ser de $1 \mathrm{ml} / \mathrm{min}$. Injeta-se todo o extrato das células Sf9 após ultracentrifugação do mesmo (Rosenblatt et al., 1993) na coluna DEAE-Sepharose com uma vazão de $1 \mathrm{ml} / \mathrm{min}$, coletase todo o fluxo que sai da coluna em um tubo (tubo 1). Lava-se a coluna com $10 \mathrm{ml}$ de tampão HN25E e coleta-se no mesmo tubo 1. O volume total esperado no tubo 1 quando se usa $450 \mathrm{ml}$ de células Sf9 infectadas( com aproximadamente $2 \times 10^{6}$ células por $\mathrm{ml}$ ) é de aproximadamente $45 \mathrm{ml}$. Feito isto a coluna DEAE-Sepharose é lavada com 30ml de tampão HN1000E, para remoção de impurezas e então lavada com $30 \mathrm{ml}$ de tampão HN25E e armazenada para uso futuro. Elevamos a concetração salina do tubo 1 contendo CDK2 obtida com o uso da coluna DEAE-Sepharose para $50 \mathrm{mM}$ de $\mathrm{NaCl}$. Injetamos agora o conteúdo deste tubo 1 na coluna S-Sepharose com uma vazão de $1 \mathrm{ml} / \mathrm{min}$. Coletamos todo o volume que sai da coluna S-Sepharose em um novo tubo (tubo 2), que deve conter a CDK2. Lavamos a coluna S-Sepharose com $30 \mathrm{ml}$ de tampão HN1000E para extrair impurezas e em seguida lavamos com $30 \mathrm{ml}$ de tampão HN25E com $0,02 \%$ de

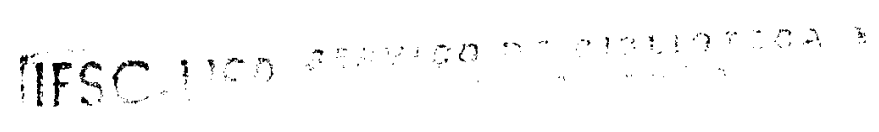


azida para ser armazenada. Até o momento as colunas foram montadas em uma configuração bem simples, sem o coletor automático de frações e sem o misturador de gradiente. Para o uso da última coluna, ATP-Agarose, temos o sistema montado como mostrado na figura 2.7. Injeta-se todo o volume do tubo 2 na coluna ATP-Agarose com uma vazão fixada em $0,3 \mathrm{ml} / \mathrm{min}$ e coleta-se o fluxo que sai da coluna em um novo tubo (tubo 3). A CDK2 está agora ligada à coluna de afinidade ATP-Agarose. Inicia-se então a eluição por gradiente linear, para a extração da CDK2. O misturador de gradiente usa $c_{2}=1 \mathrm{M}\left(25 \mathrm{ml}\right.$ de tampão HN1000EG) e $c_{1}=0 \mathrm{mM}$ ( $25 \mathrm{ml}$ de tampão HNOEG) (equação 2.2). O coletor de frações é calibrado de forma que cada fração coletada tenha um volume de $1 \mathrm{ml}$. A CDK2 usualmente está presente nas frações de 6 a 19. Com uma média de $10 \mathrm{mg}$ de $\mathrm{CDK} 2$ pura em cada preparação. Esta CDK2 é inativa, visto que, o monômero é inativo, mas pode ser totalmente ativada quando complexada com ciclina A e misturada com CAK. Os testes de atividades são feitos contra histona H1 (Rosenblatt et al, 1993).

Tabela 2.3. Lista de tampões utilizados na purificação de CDK2.

\begin{tabular}{|c|c|}
\hline Identificação & Composição \\
\hline \multirow[t]{3}{*}{ HN25E } & 10mM HEPES $\mathrm{pH} 7,4$ \\
\hline & $25 \mathrm{mM} \mathrm{NaCl}$ \\
\hline & lmM EDTA e $1 \mathrm{mM}$ DTT \\
\hline \multirow[t]{3}{*}{ HN50E } & 10mM HEPES $\mathrm{pH} 7,4$ \\
\hline & $50 \mathrm{mM} \mathrm{NaCl}$ \\
\hline & $1 \mathrm{mM}$ EDTA e $1 \mathrm{mM}$ DTT \\
\hline \multirow[t]{3}{*}{$\mathrm{HN} 1000 \mathrm{E}$} & 10mM HEPES $\mathrm{pH} 7,4$ \\
\hline & $1000 \mathrm{mM} \mathrm{NaCl}$ \\
\hline & $1 \mathrm{mM}$ EDTA e $1 \mathrm{mM}$ DTT \\
\hline \multirow[t]{3}{*}{ HNOEG } & $10 \mathrm{mM}$ HEPES $\mathrm{pH} 7,4$ \\
\hline & $10 \%$ Glicerol \\
\hline & $1 \mathrm{mM}$ EDTA e $1 \mathrm{mM}$ DTT \\
\hline \multirow[t]{4}{*}{ HN1000EG } & 10mM HEPES $\mathrm{pH} 7,4$ \\
\hline & $1000 \mathrm{mM} \mathrm{NaCl}$ \\
\hline & $10 \%$ Glicerol \\
\hline & $1 \mathrm{mM}$ EDTA e $1 \mathrm{mM}$ DTT \\
\hline
\end{tabular}




\section{CAPÍTULO 3}

\section{CRISTALIZAÇÃO DE MACROMOLÉCULAS BIOLÓGICAS}

\subsection{Introdução (Ducruix \& Giegé,1992).}

O principal objetivo da cristalização de uma macromolécula biológica, tal como proteína, ácido nucleíco ou vírus, é o estudo estrutural destas macromoléculas, por métodos de difração de raios $\mathrm{X}$. Tal estudo estrutural é fundamental para o entendimento molecular de vários mecanismos biológicos.

Os cristais de macromoléculas biológicas são diferentes dos cristais de pequenas moléculas em vários aspectos. Eles diferem em tamanho, cristais de macromoléculas são normalmente bem menores, dificilmente excedem $1 \mathrm{~mm}^{3}$ em volume. Uma outra diferença é que cristais de macromoléculas biológicas são bem mais frágeis e possuem um alto conteúdo de solvente. A fragilidade dos cristais de macromoléculas biológicas é uma conseqüência das fracas interações entre as macromoléculas biológicas dentro da rede cristalina e do alto conteúdo de solvente nestes cristais ( de $20 \%$ a mais de $80 \%$ ). As ligações fracas que mantêm a estrutura cristalina destas macromoléculas biológicas são do tipo hidrofôbico e ligação de hidrogênio. Por esta razão, os cristais de macromoléculas biológicas devem ser mantidos em um ambiente saturado de solvente, caso contrário, a desidratação conduzirá à quebra destas ligações fracas e consequente destruição dos cristais. O alto conteúdo de solvente, contudo, tem conseqüências úteis, pois os canais de solvente nos cristais de macromoléculas biológicas permitem a difusão de pequenas moléculas, uma propriedade usada na preparação de derivados isomorfos e de complexos binários de proteína e ligante. Uma outra característica dos cristais de macromoléculas biológicas são as grandes dimensões de suas celas unitárias, se comparadas com as dimensões das celas unitárias das pequenas moléculas. Cristais de macromoléculas biológicas podem ter parâmetros de cela unitária de até algumas dezenas de milhares de ångstrons (Usha., et al, 1984). 


\subsection{Princípios gerais para cristalização de macromoléculas biológicas (Ducruix \&}

Giegé, 1992).

Uma das partes mais críticas na resolução da estrutura de uma macromolécula biológica é a cristalização da mesma. Os principais passos envolvidos na resolução da estrutura a nivel atômico de uma macromolécula biológica estão mostrados na figura 3.1.

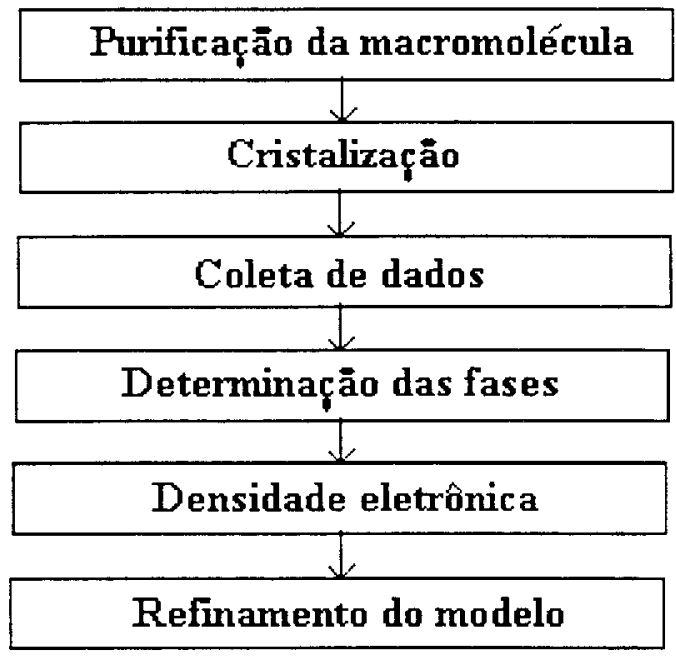

Figura 3.1. Passos envolvidos na resolução de uma estrutura tridimensional por difração de raios $X$

E entre todos estes passos a cristalização é o menos entendido. Biocristalização, como qualquer cristalização, é um processo de múltiplos parâmetros, que envolve os três passos clássicos da cristalização, que são: nucleação, crescimento e cessação de crescimento (cessation of growth). O que faz com que o processo de cristalização de macromoléculas biológicas seja diferente é que o processo envolve um número de parâmetros (Tabela 3.1), muito maior do que aquele envolvido no crescimento de cristais de pequenas moléculas, e as propriedades fisico-químicas peculiares destes compostos. Por exemplo, a estabilidade ótima das macromoléculas biológicas em um meio aquoso está restrita a uma faixa estreita de $\mathrm{pH}$. Mas a principal diferença entre crescimento de cristais de pequenas moléculas e cristais de macromoléculas biológicas é a flexibilidade conformacional e a versatilidade química dessas macromoléculas $\mathrm{e}$, consequentemente, sua maior sensibilidade às condições externas 
Tabela 3.1. Parâmetros que afetam cristalização (e/ou solubilidade) de macromoléculas biológicas

\section{Parâmetros físico-químicos intrínsecos:}

- Supersaturação (Concentração das macromoléculas e precipitantes)

- Temperatura, pH (Flutuações destes parâmetros)

- Tempo (Cinética do equilibrio e crescimento)

- Força iônica e pureza das substâncias químicas utilizadas

- Difusão e convecção (gels e microgravidade)

- Volume e geometria das amostras ( superfície das câmaras de cristalização)

- Partículas sólidas, efeitos de parede e interface

- Efeitos de densidade e viscosidade ( diferenças entre cristal e líquido-mãe)

- Pressão, campos elétricos e magnéticos

- Vibrações e som (ondas acústicas)

- Seqüência de eventos (experimentalista versus robô)

\section{Parâmetros bioquímicos e biofísicos:}

- Sensibilidade das conformações aos parâmetros físicos (temperatura, pH, força iônica,...)

- Ligação de substratos, cofatores, ions metálicos e outros íons

- Aditivos específicos ( agentes redutores, detergentes não iônicos, poliaminas,...)

- Envelhecimento da amostra (degradação e desnaturação)

\section{Parâmetros biológicos:}

- Pequena quantidade da maioria das macromoléculas biológicas

- Fontes biológicas e estado fisiológico dos organismos ou células

\section{Pureza das macromoléculas:}

- Contaminantes macromoleculares

- Heterogeneidades da seqüência de amino-ácidos

- Heterogeneidade conformacional 
Para um planejamento racional das condições de cristalização é necessário o controle dos parâmetros físicos e biológicos. A seguir descreveremos três dos principais parâmetros a serem controlados num experimento de cristalização de uma macromolécula biológica.

\subsubsection{Pureza da macromolécula biológica.}

Devido ao fato que as macromoléculas são extraídas de complexas misturas biológicas, tais como as células, a purificação é um passo importante para a cristalogênesis. Pureza, entretanto, não é uma condição primordial para a cristalização, visto que, cristais de macromoléculas biológicas podem algumas vezes ser obtidos de misturas de macromoléculas, onde temos uma ou mais macromoléculas biológicas como contaminante. Mas, tais cristais, são na maioria das vezes bem pequenos, ou então, crescem como massas policristalinas, que não são adequadas para estudos cristalográficos por difração de raios $\mathrm{X}$. Para o uso de técnicas de difração de raios X é necessário o uso de cristais com a menor dimensão por volta de $0,2 \mathrm{~mm}$, contudo com uso de fontes de raios $\mathrm{X}$ bem intensa, tais com síncrotrons, tem sido possível a resolução de estruturas de macromoléculas biológicas cujos cristais apresentavam dimensões menores que $0,1 \mathrm{~mm}$. Como regra geral, pode-se dizer que, a baixa pureza da macromolécula biológica é a causa mais comum da falta de sucesso na cristalização da mesma.

\subsubsection{Solubilidade e supersaturação.}

Para crescer cristais de qualquer composto, as moléculas ou ions têm de ser trazidos a um estado de supersaturação, um estado que é termodinamicamente instável, no qual pode se desenvolver numa fase amorfa ou cristalina quando este retornar ao equilibrio. Supersaturação pode ser alcançada pela evaporação lenta do solvente ou pela variação de alguns dos parâmetros listados na tabela 3.1. Disto segue que, o conhecimento das solubilidades macromoleculares é um pré-requisito para o controle das condições de cristalização. Assim, como as bases teóricas da solubilidade são ainda controversas, especialmente no que tange efeitos dos sais, os dados sobre a solubilidade quase sempre se originam de determinações experimentais. Nos últimos anos, métodos quantitativos 
permitiram tais determinações, usando pequenas quantidades de proteína (Mikol \& Giegé, 1989; Ries-Krautt \& Ducruix, 1989). O principal resultado destes métodos foi a demonstração experimental da complexidade do comportamento da solubilidade, enfatizando a importância da determinação de diagramas de fase para o planejamento racional de experimentos de crescimento de cristais de macromoléculas biológicas.

\subsubsection{Nucleação, crescimento e cessação de crescimento (cessation of growth).}

Devido ao fato que proteínas e ácidos nucléicos necessitam $\mathrm{pH}$ e força iônica definidas para a sua estabilidade e função, cristais de macromoléculas biológicas têm de ser crescidos a partir de soluções aquosas complexas. A cristalização começa com a fase de nucleação (i.e. a formação dos primeiros agregados ordenados) que é seguida pela fase de crescimento. As condições para se atingir a nucleação são algumas vezes dificeis de se repetir, e desta forma os procedimentos de semeação (seeding) com um material cristalino pré-formado se faz necessário. Em muitos casos este é o único método para se obter resultados reprodutíveis. A nucleação requer um estado de supersaturação maior do que aquele da fase de crescimento. A velocidade da cristalização aumenta com a supersaturação, desta forma nucleação e crescimento deveriam ser desacoplados, o que quase nunca é realizado concientemente.

A cessação de crescimento (cessation of growth) de uma macromolécula biológica pode ter diversas causas, desconsiderando as triviais, como remoção da macromolécula do meio de cristalização, temos causas tais como, defeitos de crescimento, envenenamento das faces, ou envelhecimento da macromolécula.

\subsection{Conceitos sobre solubilidade (Ducruix \& Giegé, 1992).}

Para se cristalizar uma macromolécula biológica em um dado solvente, é necessário levar a solução a um estado de supersaturação. Uma macromolécula biológica segue as mesmas leis da termodinâmica, como qualquer outro tipo de molécula ( inorgânica ou orgânicas) no que se refere à supersaturação, nucleação, e crescimento de cristais (Boistelle \& Astier, 1988). Todavia, macromoléculas biológicas apresentam peculiaridades, porque as interações necessárias para solubilizá-las num solvente são 
similares, e podem ser competitivas com as interações intermoleculares que são responsáveis pela estrutura tridimensional da macromolécula.

\subsection{Solubilidade de macromoléculas biológicas (Ducruix \& Giegé,1992).}

Em geral, a solubilidade de um composto químico em um solvente, a uma dada temperatura, é definida como a quantidade de composto dissolvida em uma solução em equilibrio com um excesso de composto não dissolvido; e.g. à $25^{\circ} \mathrm{C}$, o sal sulfato de amônia se dissolve até que sua concentração atinja 4,1 moles por litro de água, o excesso permanece não dissolvido. Mais sal pode ser dissovido quando se eleva a temperatura, e quando a temperatura é trazida de volta a $25^{\circ} \mathrm{C}$, a solução atinge à supersaturação. $\mathrm{O}$ excesso de sal cristalizará, até que a concentração do sal atinja seu valor de solubilidade à $25^{\circ} \mathrm{C}(4,1$ moles por litro de água).

No caso de macromoléculas biológicas, a solubilidade é definida também pelas características do solvente. Como o solvente consiste usualmente de água a qual foram adicionadas diversas substâncias químicas para levar a solução até um dado pH (tampão), força iônica (sais), e eventualmente outros aditivos, estes compostos podem afetar a solubilidade da macromolécula biológica das seguintes formas:

(a) diretamente, pela interação com diferentes grupos funcionais da macromolécula e, eventualmente, modificando a conformação da macromolécula. Trabalhar em diferentes condições de tampão e sais é como trabalhar como uma macromolécula diferente do ponto de vista fisico-químico.

(b) indiretamente, através da modificação das propriedades fisico-químicas do solvente; e.g. variação do $\mathrm{pH}$ modifica a carga líquida da proteína e desta forma a natureza do polieletrólito. Além disso, se pontes salinas estão envolvidas na estrutura tridimensional, estas podem se quebrar e a macromolécula pode modificar sua conformação.

Uma macromolécula biológica é um polímero de amino ácidos ou nucleotídeos, os quais estão enovelados em uma estrutura tridimensional:

- principalmente por interações dipolo-dipolo, ligações de hidrogênio (e.g. $\mathrm{C}=\mathrm{O}{ }^{\cdots+} \mathrm{H}-\mathrm{N}$ ), 
e por interações de van der Waals;

- por algumas ligações covalentes ( pontes S-S);

- eventualmente por pontes salinas ( e.g. $-\mathrm{COO}^{-\cdots+} \mathrm{H}_{3} \mathrm{~N}-$ ) entre residuos carregados.

Proteínas apresentam as cadeias laterais hidrofóbicas preferencialmente no seu interior enquanto as cadeias laterais hidrofilicas se localizam principalmente na sua superficie. Desta forma as proteínas podem sem consideradas como polieletrólitos capazes de se dissolverem em água.

A estabilidade das macromoléculas biológicas em solução baseia-se na competição das interações solvente-soluto com interações intramoleculares as quais são necessárias para manter a estrutura da macromolécula. O balanço das interações que controlam a solubilidade e/ou a conformação de uma macromolécula podem ser modificadas por (von Hippel \& Schleich, 1969):

(a) Temperatura. Um aumento da temperatura aumenta a desordem das moléculas de solvente e permite também que conformações da macromolécula de mais alta energia livre total se formem.

(b) $\mathrm{pH}$. Como a temperatura, variações no $\mathrm{pH}$ afetam ambos soluto e solvente. Todavia, alteranções das concentrações de $\mathrm{H}^{+}$e $\mathrm{OH}^{-}$são minoritárias se comparadas com a protonação e desprotonação de grupos da macromolécula.

(c) Sais. Sais podem agir de diferentes formas. (i) Eles são responsáveis pela força iônica, e desta forma afetam as interações eletrostáticas da macromolécula por meio de blindagem de cargas. (ii) Eles podem formar interações eletrostáticas diretas com residuos carregados na superficie das macromoléculas. (iii) Sais podem agir através de interações monopolo-dipolo com grupos dipolares da macromolécula biológica.

(d) Competidores de ligações de hidrogênio. Moléculas que possuem um potencial para formarem ligações de hidrogênio competem a alta concentração $(>4 \mathrm{M})$ com ligações de hidrogênio da água e ligações de hidrogênio intramoleculares na proteína.

(e) Aditivos hidrofóbicos. Eles podem agir diretamente com partes hidrofóbicas da macromolécula e podem também alterar a estrutura do solvente. Detergentes nãoiônicos agem desta forma (McPherson, et al., 1986). 
(f) Solventes orgânicos. A adição de solventes orgânicos implica na modificação da constante dielétrica e consequentemente variações em diversas interações.

\subsection{Salting-in e salting-out (Drenth, 1994; Ducruix \& Giegé,1992).}

A dependência da solubilidade da proteína com a concentração salina foi estudada em termos dos fenômenos de salting-in e salting-out (Green, 1932). O aumento da solubilidade de uma macromolécula biológica a baixa concentração salina $(<0,5 \mathrm{M})$ é chamada salting-in. Este fenômeno é explicado pelas interações eletrostáticas não especificas entre a macromolécula carregada e as espécies iônicas do sal. Segundo a teoria de Debye-Hückel para soluções iônicas, um aumento na força iônica reduz a atividade dos íns em solução e aumenta a solubilidade do composto iônico. Uma forma alternativa de se tratar este fenômeno é considerar o salting-in como o resultado da competição entre grupos carregados na superficie da macromolécula e os íons em solução. Na ausência de íns de solvente a macromolécula precipita devido à atração de Coulomb entre cargas opostas em diferentes partes da macromolécula. Se os íons são adicionados à solução eles blindam os grupos carregados na macromolécula e aumentam a sua solubilidade (figura 3.2).

Outra forma de precipitar uma macromolécula é feito pela adição de sal (salting$o u t)$, este serve para imobilizar as moléculas de água, desta forma aumentando a concentração efetiva da macromolécula, ou seja, diminuindo a sua solubilidade. No fenômeno de salting-out a solubilidade da macromolécula biológica é governada principalmente por efeitos hidrofôbicos. De acordo com a equação linear empírica de Cohn-Green a solubilidade da macromolécula numa situação de salting-out decresce da seguinte forma:

$$
\log S=\beta-K_{S} m, \text { ou } \log S=\beta-K_{s^{\prime}}^{\prime} \mu
$$

onde $\mathrm{S}$ é a solubilidade da macromolécula biológica, $\beta$ o intercepto para $\mathrm{m}=0$, é uma constante para altas concentrações salinas e é função da carga líquida da macromolécula e altamente dependente do $\mathrm{pH}$ da solução ( no ponto isoelétrico $(\mathrm{pI}), \beta$ tende a zero). A 
magnitude de $\beta$, bem como a distribuição de cargas, variam com a temperatura. $K_{S}$ é $K_{S}$ ' são constantes de salting-out. São independentes da temperatura e $\mathrm{pH}$, mas dependem da natureza dos sais presentes na solução. A molaridade é indicada por $\mathrm{m}$. $\mathrm{E}$ a força iônica por $\mu$, esta força leva em conta a valência $Z_{i}$ de todos os íons presentes na solução. $A$ expressão da força iônica é dada por:

$$
\mu=1 / 2 \Sigma\left(m_{i} Z_{i}\right)
$$

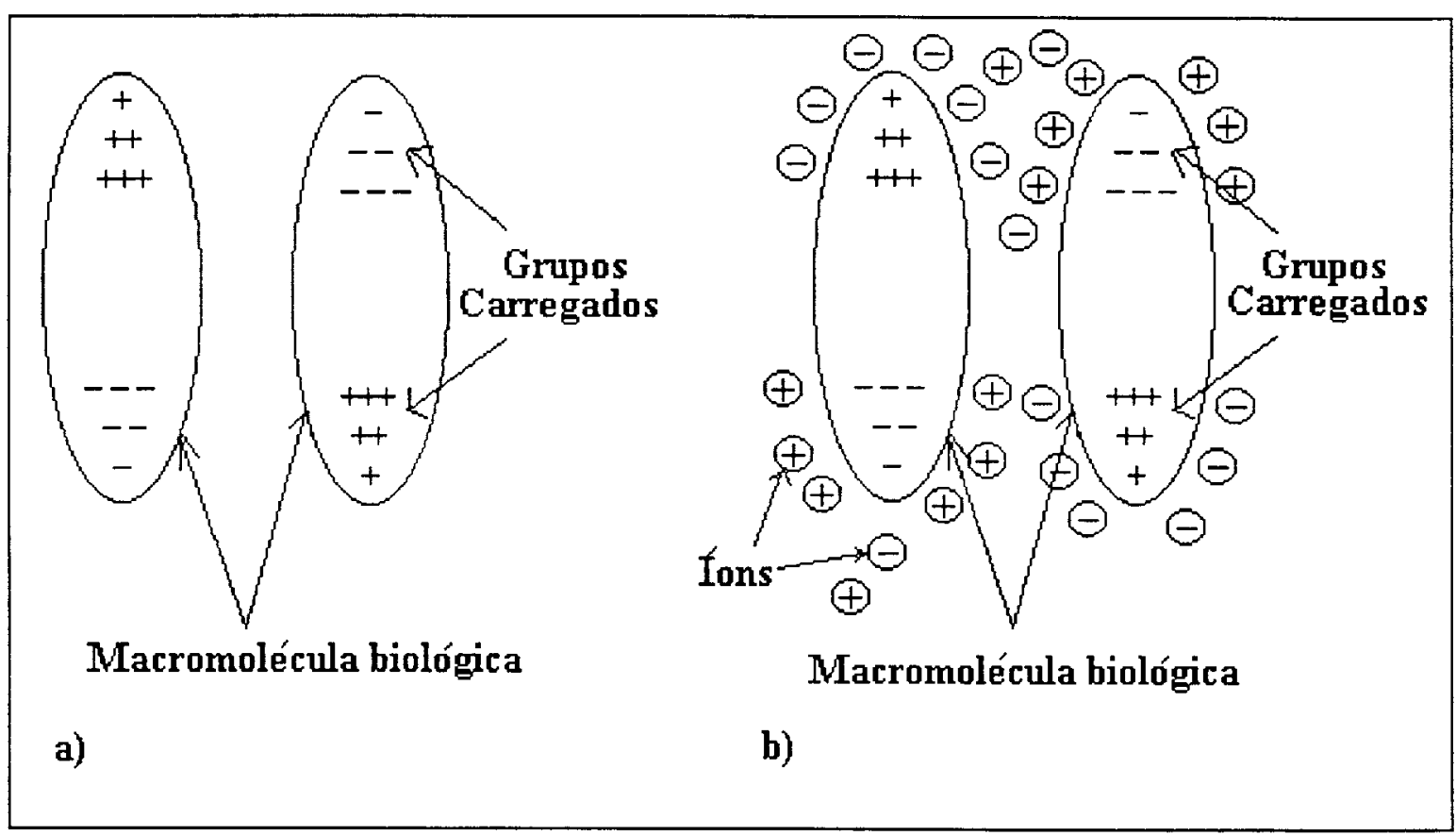

Figura 3.2. Fenômeno de salting-in. a) Macromolécula biológica sem a presença de íons dissolvidos na solução. A atração eletrostática entre os grupos carregados em duas os mais macromoléculas causa a aglomeração e precipitação. b) A adição íons em solução blindam a interação eletrostática entre as macromolécula, aumentando a solubilidade.

Um composto adicionado a um sistema macromolécula biológica + água (soluto+solvente) pode se ligar à macromolécula ( ligação preferêncial) ou ser excluído (exclusão preferencial). A interação líquida do salting-out é exclusão preferencial, mesmo que moléculas possam se ligar à macromolécula biológica.

A variação da solubilidade das macromoléculas biológicas (S) na faixa completa de concentração salina reflete o efeito de ambas interações, eletrostática e hidrofóbica, a 
primeira sendo predominante a baixas concentrações salinas e a segunda a altas concentrações salinas como mostrado na figura 3.3. Isto é expressado pela seguinte equação (Green, 1932):

$$
\log S=\log S_{o}+k_{i} C^{1 / 2}-k_{o} C
$$

onde $\mathrm{k}_{\mathrm{i}}$ e $\mathrm{k}_{\mathrm{o}}$ são as constantes de salting-in e salting-out respectivamente; $\mathrm{S}_{\mathrm{o}}$ é a solubilidade da macromolécula biológica em água pura; e C a concentração molar salina

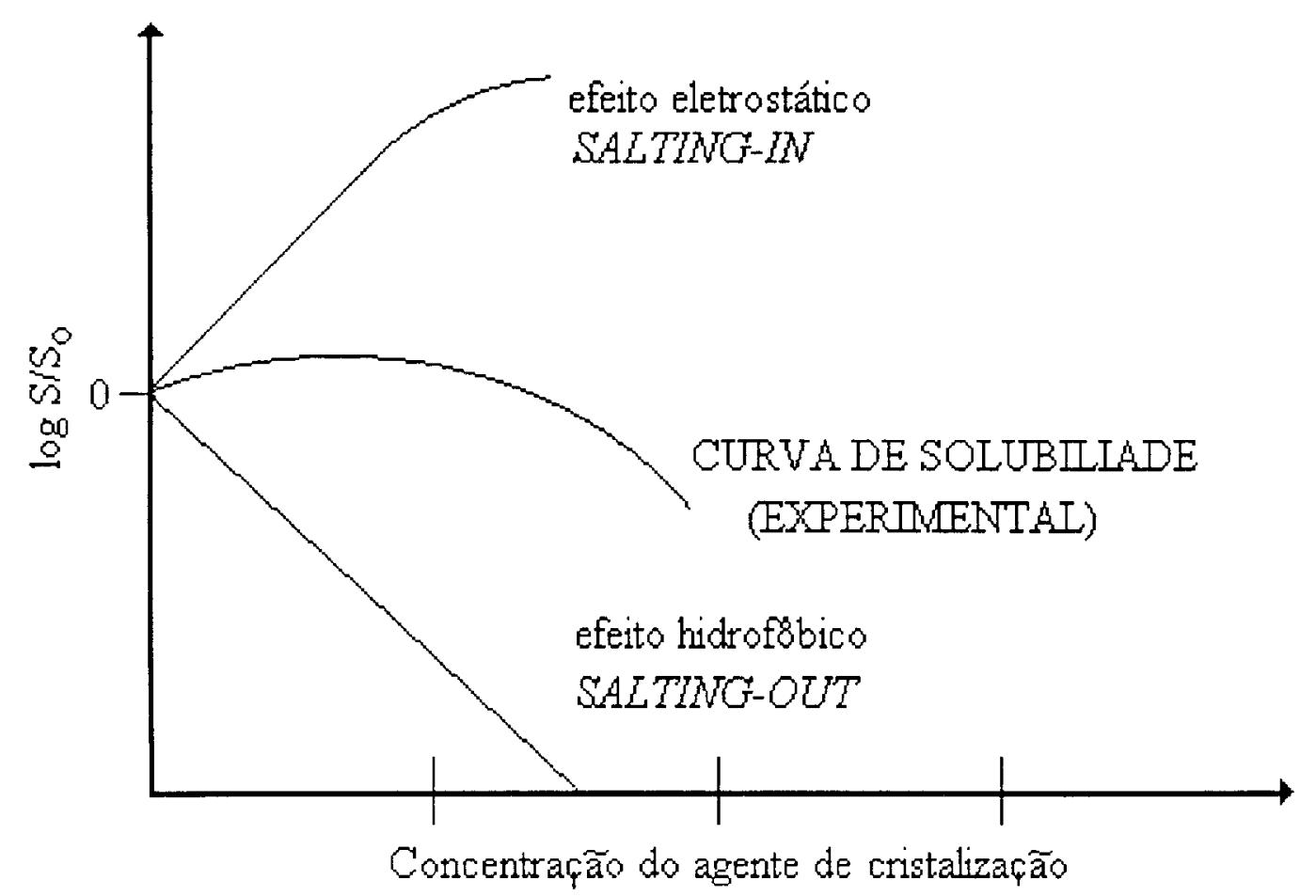

Figura 3.3. Contribuição dos efeitos eletrostático e hidrofóbico sobre a solubilidade $S$, normalizada em relação à solubilidade em água pura $\mathrm{S}_{0}$.

\subsection{Diagramas de fase de macromoléculas biológicas (Ducruix \& Giegé,1992b).}

Como a solubilidade de uma macromolécula biológica depende de diversos parâmetros (veja tabela 3.1), um diagrama bidimensional é uma representação desta solubilidade ( $\mathrm{mg} / \mathrm{ml}$ ou $\mathrm{mM}$ de macromolécula em solução) como função de dois 
parâmetros, com todos outros sendo mantidos constantes. Um diagrama deste tipo está representado na Figura 3.4, e compreende as seguintes zonas:

(a) A curva de solubilidade (S) separa as zonas supersaturadas e hiposaturadas. Em um experimento onde as concentrações do agente de cristalização e da macromolécula biológica correspondem às condições da curva $S$, a solução saturada da macromolécula está em equilíbrio com a macromolécula cristalizada. Isto corresponde à situação ao final do processo de crescimento do cristal a partir de uma solução supersaturada, ou da dissolução de cristais em uma solução hiposaturada.

(b) Abaixo da curva de solubilidade (S) a solução está hiposaturada e a macromolécula biológica nunca irá cristalizar.

(c) Acima da curva de solubilidade (S), a concentração da macromolécula biológica é maior que a concentração no equilíbrio para uma dada concentração salina. Isto corresponde a uma zona de supersaturação. Dependendo da cinética para se atingir o equilíbrio e do nível de supersaturação, esta região pode ser dividida em três zonas: (i) A zona de precipitação é onde o excesso de macromolécula imediatamente se separa da solução em um estado amorfo.(ii) A zona de nucleação é onde o excesso da macromolécula biológica se separa sob a forma cristalina. Próxima à zona de precipitação, a cristalização pode ocorrer com um "chuveiro" (shower) (uma grande quantidade de cristais) que podem ser confundidos com precipitado amorfo, pois os cristais apresentam dimensões bem reduzidas assemelhando-se, muitas vezes, a um pó.(iii) $\mathrm{Na}$ zona metaestável uma solução supersaturada pode não nuclear, ou seja, pode não gerar cristais, por um longo período de tempo, a menos que a solução seja mecanicamente pertubada ou uma semente (um pequeno cristal) seja introduzida, processo conhecido como semeadura (seeding). Classicamente este processo se divide em macrossemeadura (macroseeding), onde um cristal de dimensões "macroscópicas" é introduzido à uma solução na zona metaestável, e microssemeadura (microseeding), onde normalmente vários cristais bem pequenos são inseridos numa solução na zona metaestável, contudo esta diferenciação entre macro e micro é um tanto arbitrária, sendo que o principal é que se tem uma ou mais sementes inseridas numa solução com

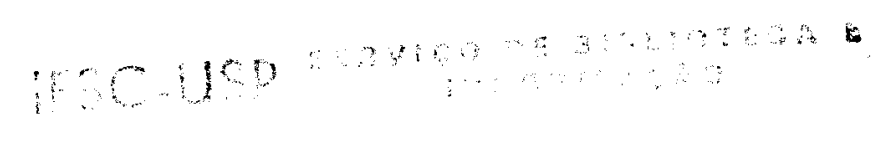


a macromolécula biológica na zona metaestável. Esta zona corresponde, idealmente, ao crescimento de cristais sem a nucleação de novos cristais.

Uma solução saturada contém uma quantidade de soluto tal que não pode haver crescimento ou dissolução se cristais são adicionados à solução, ou seja, qualquer ponto sobre a curva (S) no diagrama de fases esquemático mostrado na figura 3.4. Isto corresponde ao equilibrio termodinâmico entre as duas fases (líquido é sólido). $\mathrm{O}$ potêncial químico $(\mu)$ de cada espécie química, i, é a mesma em ambas as fases (cristal e solução):

$$
\mu_{\mathrm{ic}}=\mu_{\mathrm{is}}=\mu_{\mathrm{io}}+R T \ln \gamma c_{i}
$$

onde $\mu_{\mathrm{io}}$ é o potencial químico padrão, $\gamma$ é o coeficiente de atividade, e $c_{i}$ a concentração da espécie química i. Isto é verdadeiro para qualquer espécie química ( macromolécula, água etc...). A supersaturação é alcançada quando o potencial químico do soluto em solução é maior que o do cristal. Isto pode ser atingido através da variação de alguns dos parâmetros que afetam a solubilidade (Tabela 3.1). A supersaturação é a força motriz para a cristalização; e é definida como a diferença do potencial químico entre a solução e o cristal. Entretanto, as aproximações mais comuns são as relações $c / c_{s}$ e $\left(c-c_{s}\right) / c_{s}$ onde $c$ é a concentração da proteína e $c_{s}$ a concentração do soluto em uma solução saturada, ou seja, um ponto sobre a curva de solubilidade(S) da figura 3.4. Estas quantidades têm a vantagem de serem adimensionais. Deve-se notar que o valor da supersaturação (definido como a relação entre a concentração de macromolécula biológica $c$ e a solubilidade $c_{s}$ ) realmente encontrada nos experimentos de cristalização de macromoléculas biológicas ficam na faixa de 2 a 10 . Esta faixa é bem mais alta que aquela encontrada para crescimento de cristais de pequenas moléculas. 


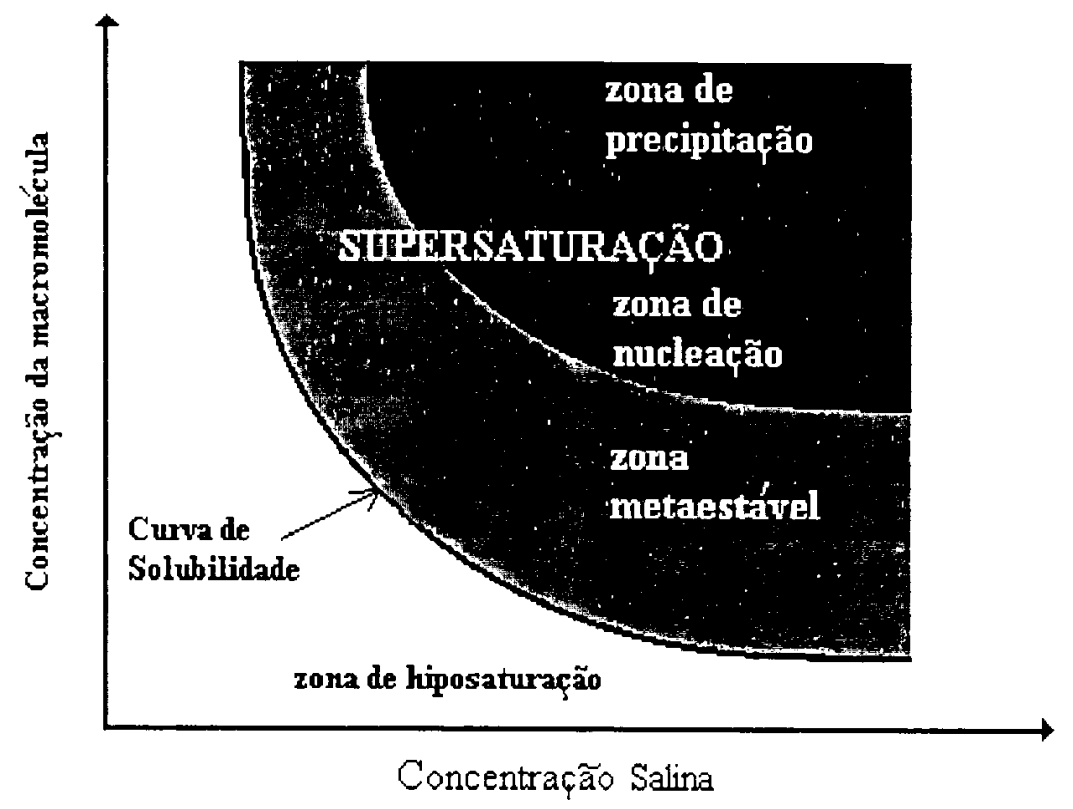

Figura 3.4. Descrição esquemática de um diagrama bidimensional da solubilidade de uma macromolécula biológica.

\subsubsection{Mecanismos de crescimento de cristais (Ducruix \& Giegé,1992).}

$\mathrm{Na}$ teoria de crescimento de cristais se divide o processo de crescimento tradicionalmente em dois passos: transferência de massa da solução para a interface cristal/solução; inclusão da molécula no cristal ( cinética da interface).A transferência de massa é governada pela difusão e convecção devido ao gradiente de densidade ou agitação (se existir). A inclusão das moléculas na rede pode ser atribuida a diversos mecanismos. Dois deles parecem ser relevantes no crescimento de macromoléculas biológicas. Um se refere ao crescimento de um cristal perfeito e o segundo ao crescimento em espiral.

No caso de uma face de um cristal perfeito, uma molécula se movendo na direção da superficie tem pouca chance de ser anexada à rede cristalina, devido ao baixo número de ligações que podem ser estabelecidas. Uma vez que as moléculas tenham formado um aglomerado bidimensional (núcleo) sobre uma superficie que excede um tamanho crítico, o crescimento irá prosseguir. Este núcleo bidimensional é então capaz de incorporar as moléculas que colidem com a superficie. Este modelo é o mais provável para a explicação do crescimento a altas concentrações. 


\subsection{Análise macroscópica dos mecanismos crescimento de cristais.}

Dependendo do modelo usado temos que a taxa de crescimento $(G)$ de uma face do cristal pode ser dada pela seguintes equações:

- Para uma nucleação bidimensional:

$$
\mathrm{G}=\mathrm{k}^{\prime}\left(\mathrm{c} / \mathrm{c}_{\mathrm{s}}\right)^{1 / 2} \exp (-\Delta \mathrm{G} / \mathrm{kT})
$$

onde k' é um coeficiente cinético, $\Delta \mathrm{G}$ é a energia livre de ativação da germinação de um aglomerado bidimensonal, $\mathrm{k}$ a constante de Boltzman e $\mathrm{T}$ a temperatura. Os outros parâmetros já foram definido previamente.

- Para o crescimento em espiral:

$$
\mathrm{G}=(1 / 2)\left(D \mathrm{~d}^{2} \mathrm{kT} \mathrm{c} / \gamma\right)\left[\ln \left(\mathrm{c} / \mathrm{c}_{\mathrm{s}}\right)\right]^{2}
$$

onde $\gamma$ é a energia livre da interface, d o diâmetro molecular e D o coeficiente de difusão.

Estas taxas de crescimento da face do cristal podem ser comparadas com as medidas experimentais de crescimento (Ducruix \& Giegé,1992), usando as equações (3.5) e (3.6)

\subsection{Crescimento de cristais de macromoléculas biológicas no espaço.}

Um dos mais interessante devenvolvimentos no crescimento de macromoléculas biológicas envolve o estudo do crescimento de cristais em ambientes de microgravidade A maior motivação atrás deste tipo de experimento é examinar os efeitos que o fluxo de conveç̧ão devido à diferença de densidade tem no crescimento de cristais. A natureza do fluxo de convecção, como visto na Terra, pode ser vista na figura 3.5. Conforme material é incorporado à suferficie do cristal, variações na densidade ocorrem na solução em torno do cristal. Sob influência da gravidade, a solução de baixa densidade em volta do cristal é aumentada, produzindo desta forma um padrão de linhas de convecção (figura 3.5). Este padrão é similar àquele gerado quando um fluido é aquecido (células de Bénard). A 
turbulência criada por esse padrão de fluxo de convecção pode influenciar o crescimento do cristal devido à criação de condições de crescimento não-uniformes através da superficie do cristal e devido a efeitos de turbulência dentro da solução. Sob condições de falta de peso, estes padrões de convecção são eliminados.

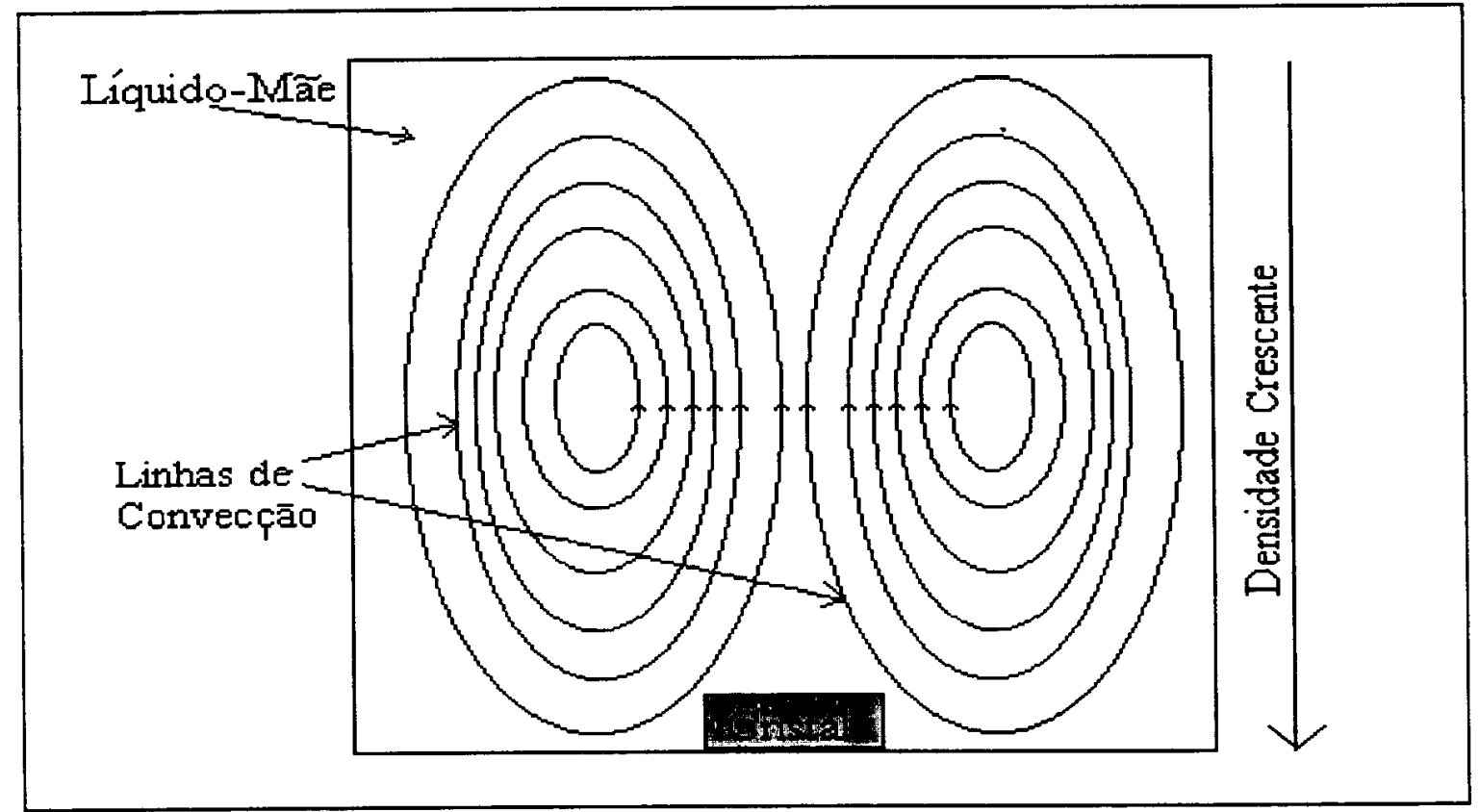

Figura 3.5. Padrão das linhas de convecção de um fluido nas condições da superficie da Terra.

Por esta razão a falta de peso, que se consegue durante um vôo orbital, fornece uma maneira direta de examinar a influência da convecção sobre o crescimento de cristais. Além disso, as condições da falta de peso podem servir para minimizar a sedimentação, que pode interferir com o crescimento uniforme dos cristais. Cristais podem, quando crescidos na Terra, se depositar no fundo do recipiente de cristalização ou ficar próximo a uma parede do reservatório de cristalização, o que limitará o crescimento naquela direção. Visto que os cristais de macromoléculas biológicas são extremamente frágeis, sendo estabilizados por ligações fracas, poderia se esperar que a formação de cristais seria especialmente afetada por flutuações no ambiente de crescimento, incluindo aquelas causadas pelos efeitos do campo gravitacional. 


\subsection{Técnicas de cristalização de macromoléculas biológicas (Ducruix \&}

\section{Giegé,1992).}

Existem muitas técnicas para a cristalização de macromoléculas biológicas, todas têm como objetivo trazer a solução da macromolécula biológica a um estado de supersaturação. As técnicas mais utilizadas são as difusão de vapor e diálise. Nós descreveremos aqui a técnica de difusão de vapor que atualmente é a mais utilizada. Esta técnica foi utilizada pela primeira vez na cristalização da tRNA. (Hampel et al., 1968). Uma gota contendo a macromolécula biológica a ser cristalizada em tampão com o agente de cristalização e aditivos é equilibrada contra um reservatório contendo a solução do agente de cristalização a uma concentração mais alta do que na gota. $O$ equilíbrio prossegue por meio da difusão das espécies voláteis (água e solventes orgânicos) até que a pressão de vapor na gota se iguale àquela do reservatório. Se o equilibrio ocorre por meio de troca da água ( da gota para o reservatório), isto leva a uma diminuição do volume da gota, e conseqüentemente a um aumento na concentração de todos os constituintes da gota de cristalização. Para espécies químicas com pressão de vapor maior que a pressão de vapor da água, a troca ocorre do reservatório para a gota. Os mesmos princípios se aplicam para gotas penduradas (hanging drops), gotas sentadas (sitting drops) e gotas sanduíches (sandwich drops).

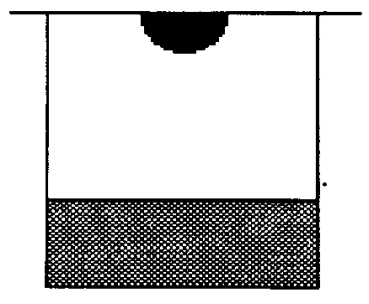

Hanging drop

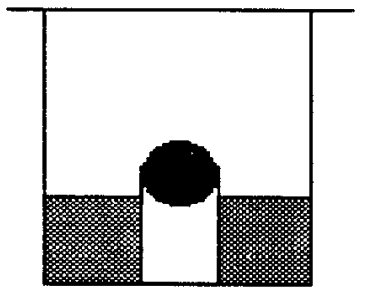

Sitting drop

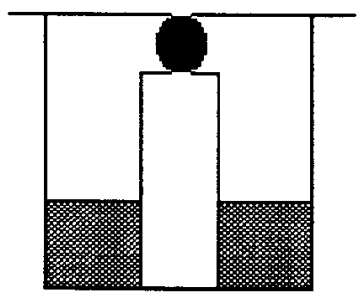

Sandwich drop

\section{Soluçào da macromolécula biológica}

\section{Reservatório com o agente de cristalizaçāo}

Figura 3.6. Representação esquemática da gota pendurada ( hanging drop), gota sentada ( sitting drop) e gota sanduíche (sandwich drop). 


\subsection{O Método da matriz esparsa (Fatorial).}

Com o aumento do número de macromoléculas biológicas cristalizadas com sucesso, tornou-se óbvio que muitas das condições de cristalização se assemelhavam, ou seja, havia uma concentração de resultados positivos de cristalização de macromoléculas biológicas usando-se um número limitado de precipitantes, tampões e aditivos. Isto levou à proposição de diversos métodos de cristalização (Carter \& Carter, 1979), onde um número limitado de condições de cristalização eram tentados, usando-se pequenas quantidades da macromolécula biológica, geralmente por volta de poucos miligramas. A partir da observação dos resultados preliminares destes experimentos era possivel determinar que tampão, aditivo e agente precipitante seriam os mais favoráveis e a partir dai proceder-se a sucessivos melhoramentos até se conseguir cristais adequados, ou ainda, em casos favoráveis, obter-se cristais adequados já na primeira tentativa com as condições padrões.

Dentro deste raciocínio a Dra. Jaru Jancarick da UC Berkeleley propôs o método da matriz esparsa ( Jancarick \& Kim, 1991) onde diversas condições diferentes são tentadas para se cristalizar a macromolécula biológica.

Visto que, o número de variáveis que afetam a cristalização, tais como, concentração, temperatura, $\mathrm{pH}$, força iônica, aditivos específicos e precipitantes, é grande e combinatória, o número total de possíveis condições de cristalização a serem testadas é tão grande que uma procura completa com todas as condições de cristalização em potencial seria inviável.

No método da matriz esparsa foram escolhidas três categorias de parâmetros que afetam a cristalização como varáveis principais, são estes: pH e materiais tampões, aditivos e agentes precipitantes. Para a variável $\mathrm{pH}$ e tampões foram escolhidos cinco diferentes pH's: 4,$6 ; 5,6 ; 6.5 ; 7,5$ e 8.5 , e para cada valor de $\mathrm{pH}$ foi escolhido o tampão químico que tinha provado ser o mais adequado para a cristalização de proteínas no passado. A escolha de aditivos também foi baseada na experiência passada de muitos laboratórios. Para os agentes precipitantes foram escolhidos quatro tipos: 2-propanol 
como agente volátil, 2-metil-2,4-pentanediol (MPD) e polietileno glicol (PEG) como agentes não-voláteis e vários agentes de salting-out. Todos estão listados na tabela 3.2.

Tabela 3.2. Parâmetros da matriz de cristalização (Jancarik \& Kim, 1991)

\begin{tabular}{|c|c|c|c|}
\hline \multicolumn{4}{|c|}{ Agentes precipitantes } \\
\hline Não-Voláteis & Sais & Voláteis & Mistura \\
\hline MPD & Tartarato de Na,K & 2-Propanol & Sulfato de $\mathrm{NH}_{4}+\mathrm{PEG}$ \\
\hline PEG 400 & Fosfato de $\mathrm{NH}_{4}$ & & 2-Propanol + PEG \\
\hline PEG 4000 & Sulfato de $\mathrm{NH}_{4}$ & & \\
\hline \multirow[t]{6}{*}{ PEG 8000} & Acetato de $\mathrm{Na}$ & & \\
\hline & Sulfato de $\mathrm{Li}$ & & \\
\hline & Formiato de $\mathrm{Na}$ & & \\
\hline & Fosfato de $\mathrm{Na}, \mathrm{K}$ & & \\
\hline & Citrato de $\mathrm{Na}$ & & \\
\hline & Formiato de $\mathrm{Mg}$ & & \\
\hline Faixa de $\mathrm{pH}$ : & 4,$6 ; 5,6 ; 6,5 ; 7,5 \mathrm{e}$ & & \\
\hline \multicolumn{4}{|c|}{$\begin{array}{l}\text { Aditivos: Cloreto de Ca. Citrato de } \mathrm{Na} \text {, Cloreto de } \mathrm{Mg} \text {. Acetato de } \mathrm{NH}_{4} \text {, Sulfato de } \mathrm{NH}_{4} \text {, Acetato de } \mathrm{M} \\
\text { Acetato de } \mathrm{Zn} \text { e Acetato de Ca. }\end{array}$} \\
\hline
\end{tabular}

Por tentativa e erro a matriz multimensional foi simplificada eliminando-se as condições que podem ser parcialmente representada por resultados de outras condições, as 58 condições finais estão mostradas no apêndice 1 .

\subsubsection{Aplicação do Método da Matriz Esparsa.}

Após preparar as 58 diferentes soluções, nós usamos o método de hanging drops, para testar as condições de cristalização. Colocamos $0,7 \mathrm{ml}$ de cada uma destas soluções em cada um dos reservatórios de uma caixa plástica Limbro (Limbro modelo 76-033-05). Estas caixas foram originalmente desenhadas para cultura de células e possuem 24 reservatórios. É necessário o uso de três caixas Limbro, sendo que a terceira terá só 10 reservatórios são usados, o restante dos reservatórios da terceira caixa podem ser usados 
em experimentos futuros. Teremos então 58 reservatórios com $0,7 \mathrm{ml}$ de cada uma das soluções de cristalização.

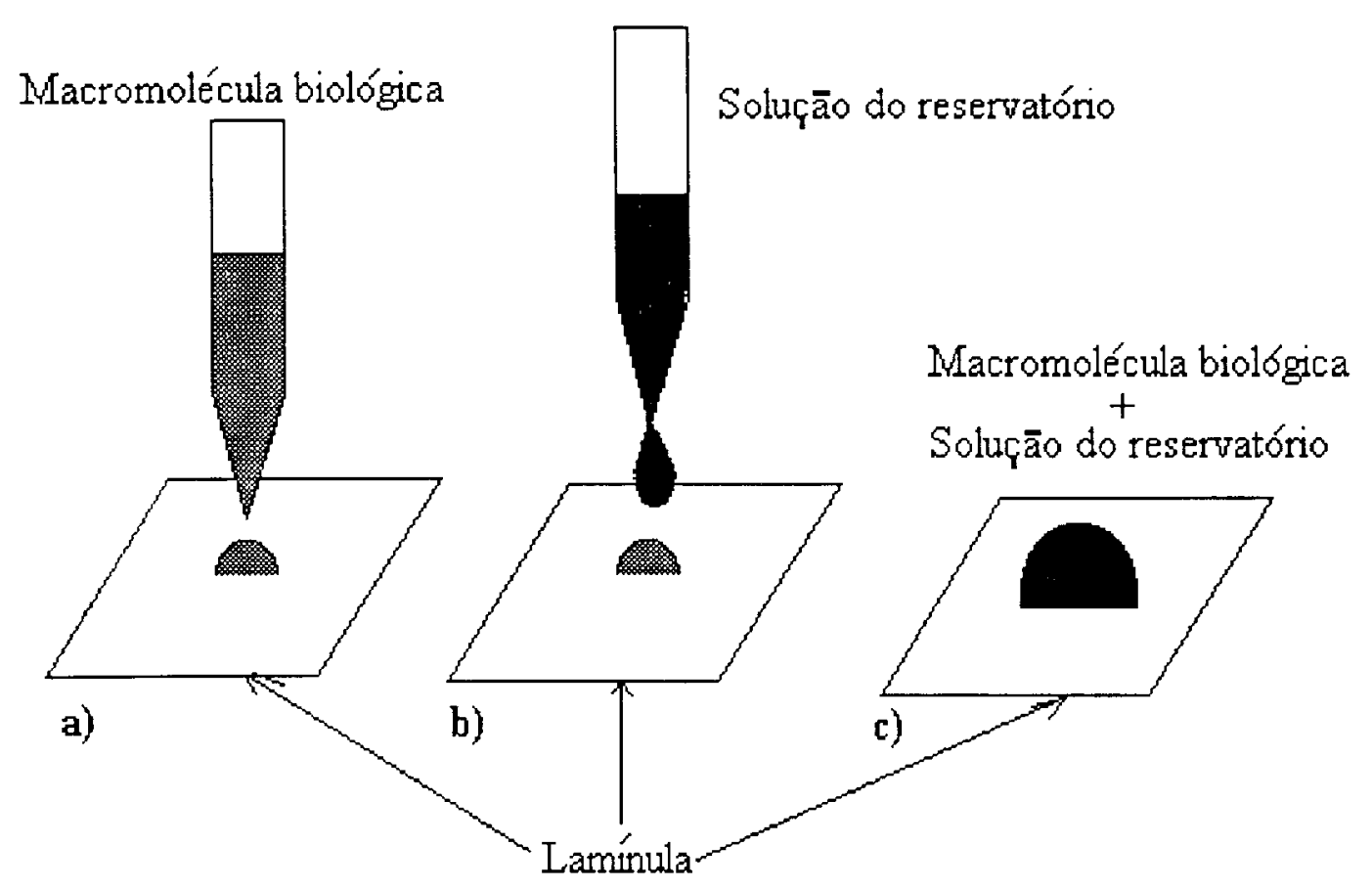

Figura 3.7. Seqüência de eventos para a montagem de uma gota de cristalização: a)

Coloca-se $1-2 \mu l$ da solução da macromolécula biológica sobre a lamínula de vidro. b) Adiciona-se 1-2ul da solução do reservatório à gota com a solução da macromolécula biológica. c) Ao final temos uma gota $(2+2)$ com a solução de macromolécula biológica mais a solução do reservátorio.

Colocamos, em seguida, 1-2 $\mu \mathrm{l}$ da solução da macromolécula biológica em uma lamínula de vidro de $22 \times 22 \mathrm{~mm}$ que foram siliniconizadas com 1\% Prosil-28 ( PCR Inc., Gainseville, Florida. U.S.A) e 1-2 $\mu$ da solução do reservatório listada no apêndice 1. (figura. 3.7). Cobrimos cada um dos reservatórios das caixas Limbro com as respectivas lamínulas de vidro onde temos $1-2 \mu$ de solução da macromolécula biológica mais $1-2 \mu l$ de solução do reservatório, usando uma graxa de vácuo para vedar os reservatórios com as lamínulas de vidro. Este tipo de composição é o que convencionou chamar-se de gota $(2+2)$. Nesta situação, teremos uma concentração menor de precipitante na gota, do que no reservatório. E a difusão de vapor d'água se procederá da gota para o reservatório No caso em que as espécies químicas do reservatório possuam pressão de vapor menor que a pressão de vapor d'água, isto fará com que a concentração da solução de

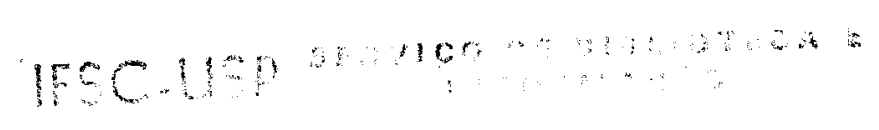


macromolécula biológica bem como das outras espécies químicas presentes na gota aumente, o que em casos favoráveis levará a macromolécula biológica a uma condição de supersaturação favorável à formação dos primeiros agregados cristalinos ( zona de nucleação). Tal composição $(2 \mu l+2 \mu l)$ pode ser mudada, bem como o volume inicial da gota, contudo em um experimento de cristalização deve-se ter em mente o uso racional da macromolécula biológica, principalmente nos experimentos preliminares de cristalização, de forma que, grandes volumes de gotas de cristalização devem ser evitados nos experimentos preliminares.

Na proposição original do método recomenda-se que a macromolécula biológica a ser cristalizada seja dissolvida em água ou no seu tampão original e trazida a uma concentração de aproximadamente $10 \mathrm{mg} / \mathrm{ml}$. Um parâmetro que pode causar problemas é a concentração inicial de $10 \mathrm{mg} / \mathrm{ml}$, pois muitas macromoléculas biológicas não conseguem atingir tal concentração sem precipitar, neste caso recomenda-se usar a mais alta concentração possível próxima a $10 \mathrm{mg} / \mathrm{ml}$.

\subsection{O Método da matriz esparsa passo a passo.}

O uso constante do método da matriz esparsa no Laboratório de Bio-cristalografia da UC Berkeley levou à confecção de um conjunto de regras básicas utilizadas nos experimentos de cristalização de uma nova macromolécula biológica. Tais regras e procedimentos foram desenvolvidos pela Dra. Jaru Jancarick, as quais descreveremos a seguir, pois podem ser de grande utilidade em qualquer projeto de cristalização de uma nova macromolécula biológica.

\subsubsection{Regras Gerais para Aplicação do Método da Matriz Esparsa.}

a) Nunca deixe qualquer gota de cristalização "clara", ou seja, sem precipitado amorfo ou cristais, após a aplicação do método da matriz esparsa, pois tal procedimento não lhe fornece qualquer tipo de informação. Assim, uma semana após ter-se preparado o primeiro experimento de cristalização usando-se as condições descritas anteriormente ( seção 3.11), aumente a concentração do precipitante no reservatório de todas as gotas que não apresentaram cristais nem precipitado. Isto deve ser feito em passos de 
5\% a cada três dias, ou seja, aumenta-se a concentração do precipitante no reservatório $5 \%$ acima da concentração anterior a cada três dias, até que se consiga cristais ou precipitado amorfo. $O$ aumento da concentração de precipitante no reservatório causa uma quebra do equilíbrio termodinâmico que foi provavelmente atingido após uma semana de feito o experimento de cristalização. Tal procedimento pode levar a macromolécula biológica à condição de supersaturação e nucleação.

b) O procedimento de "Esperar e Ver" funciona melhor que o procedimento "Use todo o material (macromolécula biológica) agora", porque no primeiro procedimento você obtem um retorno do primeiro experimento de cristalização o que permite o uso de menores quantidades de material nos próximos experimentos. Por esta razão sempre espere uma semana antes de fazer um outro experimento de cristalização com a mesma macromolécula biológica

\subsubsection{Experimento Inicial de Cristalização Usando o Método da Matriz Esparsa.}

Passo 1) Se a macromolécula biológica tiver de ser transportada mantenha-a em gelo (sem congelá-la) e adicione glicerol até $50 \%$ em volume e armazene-a em $-20^{\circ} \mathrm{C}$. Use o necessário para o experimento de cristalização inicial, geralmente entre 1 e $2 \mathrm{mg}$ é o suficiente, e coloque o restante de volta a $-20^{\circ} \mathrm{C}$. A fim de eliminar o glicerol da solução estoque, toma-se o volume desejado da macromolécula biológica em glicerol e adiciona-se um volume igual do tampão, então dialisa-se contra o tampão.

Passo 2) concentre a proteína no mesmo tampão e acrescente DTT, ou EDTA se necessário. Se existe $\mathrm{NaCl}$ no tampão é melhor eliminá-lo, desde que o $\mathrm{NaCl}$ não seja necessário para a solubilidade da macromolécula biológica.

Passo 3) Faça o fatorial à $4^{\circ} \mathrm{C}$ e a temperatura ambiente, se houver material suficiente.

Passo 4) Examine a gotas imediatamente após montado o experimento de cristalização e anote: a) o número das gotas com precipitado.

b) a presença de "sujeiras".

c) a presença de microcristais. 
Passo 5) Confira as gotas diariamente por uma semana, fazendo as mesmas anotações do passo 4. E verifique também o surgimento de algum bom cristal. É importante verificar como a macromolécula biológica se comporta com o tempo em cada gota de cristalização.

Passo 6) Supondo que pequenos cristais se formaram em uma ou mais gotas do experimento inicial de cristalização, deve-se concentrar esforços nos melhores cristais e tentar a melhoria das condições de cristalização dos mesmos. Os procedimentos para a melhoria das condições de cristalização serão mostrado a seguir.

\subsubsection{Melhoria das Condições de Cristalização.}

Consideremos o seguinte cenário onde temos pequenos cristais obtidos nos experimentos iniciais, com ou sem precipitado amorfo acompanhando-os. Para a melhoria dos cristais e eliminação do precipitado amorfo seguimos os seguinte passsos:

Passo 1) Abaixe a concentração da macromolécula e tente as mesmas condições em que obteve os primeiros cristais. Tente varias concetrações, por exemplo se os primeiros cristais foram conseguidos com a concentração de $10 \mathrm{mg} / \mathrm{ml}$ tente $9,8,7,6$ e $5 \mathrm{mg} / \mathrm{ml}$.

Espere por uma semana e se não houver melhora nos cristais,

Passo 2) Mantenha a concentração da macromolécula biológica constante e abaixe a concentração do agente precipitante.

Espere por uma semana e se não houver melhora nos cristais,

Passo 3) Adicione $0,2 \mathrm{M} \mathrm{NaCl}$ ao reservatório. Se a gota de cristalização ficar completamente "clara" (sem precipitado ou cristais) após uma semana, aumente a concentração do precipitante em incrementos de $5 \%$ a cada 3 dias. Se a gota continuar sem cristais ou precipitado $0,2 \mathrm{M}$ de $\mathrm{NaCl}$ foi demasiado, tente novamente com $20 \mathrm{mM}$ $\mathrm{NaCl}$ o mesmo procedimento.

A eliminação do precipitado, se presente, é importante visto que o mesmo age como sitio de nucleação e complica a manipulação futura do cristal.

$\mathrm{Se}$ não houve melhoria nos cristais pode-se tentar microssemeadura (microseeding) caso tal tentativa não funcione pode-se tentar variar a temperatura, caso o experimento foi realizado a $4^{\circ} \mathrm{C}$, deve-se tentar em temperatura ambiente e vice-versa 


\subsubsection{Exemplo de Cristalização de Uma Macromolécula Biológica.}

Como exemplo da aplicação do método da matriz esparsa para a cristalização de macromoléculas biológicas consideremos a cristalização da CDK2. A Cinase CDK2 foi cristalizada em 1993 no laboratório de bio-cristalografia da UC Berkeley ( Rosenblatt, et al., 1993). Uma solução de CDK2 foi concentrada a $10 \mathrm{mg} / \mathrm{ml}$ por diálise contra um tampão 20mM Hepes (pH 7,4) com 1mM EDTA. A solução concentrada de CDK2 foi montada num experimento de hanging drops, como descrito anteriormente, usando as 58 condições de cristalização descritas no apêndice 1 , e gota de $2 \mu l$ de proteína mais $2 \mu \mathrm{l}$ de solução do reservatório. Os experimentos de cristalização foram mantidos numa câmara fria a $4^{\circ} \mathrm{C}$. Os primeiros cristais apereceram após 24 horas de montado o experimento nas condições número $16(0,1 \mathrm{M}$ Hepes $1,5 \mathrm{M}$ Sulfato de $\mathrm{Li})$ e $36(0,1 \mathrm{M}$ Tris $8 \%$ PEG 8k), em ambas condições os cristais eram de dimensões reduzidas sendo que os melhores eram os que foram cristalizados na presença de Hepes. Seguimos esta condição para as tentativas de melhoria. Como tínhamos uma grande concentração de pequenos cristais resolvemos reduzir a concentração de precipitante, Sulfato de Li e tentamos as concetrações de 1,0M, $0,8 \mathrm{M}, 0,5 \mathrm{M}, 0,1 \mathrm{M}$. Os melhores cristais apareceram para a concetração de $0.1 \mathrm{M}$ de Sulfato de Li. Diminuímos a concetração ainda mais $(0,05 \mathrm{M}, 0,01 \mathrm{M})$ e tentamos também sem Sulfato de Li. Os melhores cristais foram conseguidos sem sulfato de Li. Em resumo a condição refinada para a cristalização ficou sendo $0.1 \mathrm{M}$ Hepes $(\mathrm{pH} 7,4)$ no reservatório. 


\section{CAPÍTULO 4 \\ DIFRAÇÃO DE RAIOS X}

\subsection{Introdução.}

Neste capítulo discutiremos alguns tópicos relacionados à difração de raios $\mathrm{X}$, destacando alguns conceitos básicos relevantes para estudos cristalográficos. Descartaremos discussões sobre a simetria do retículo direto, sendo que para interpretação da difração usaremos o espaço recíproco. Inicialmente consideraremos o espalhamento por elétrons (Thomson e Compton) depois analisaremos o espalhamento por átomos, até a consideração final da difração por um cristal. A seguir definiremos espaço recíproco e introduziremos o conceito de esfera de Ewald. Finalmente formulamos o problema da fase que será a base para a discussão dos métodos de resolução de estrutura.

\subsection{Espalhamento Thomson (Woolfson, 1970, Cullity, 1956).}

$\mathrm{O}$ campo elétrico oscilante associado ao feixe de raios $\mathrm{X}$ que incide sobre um elétron, obriga este elétron a oscilar em torno da sua posição de equilibrio. Sabemos que toda partícula carregada acelerada emite radiação. Assim o elétron, submetido a um campo elétrico oscilante, emite uma onda eletromagnética, que possue o mesmo comprimento de onda da radiação incidente (espalhamento elástico). A intensidade do feixe de raios $\mathrm{X}$ espalhado por um elétron de carga -e e massa m a uma distância $r$ do elétron é dada por,

$$
\mathrm{I}=\mathrm{Io} \frac{\mathrm{e}^{4}}{\mathrm{r}^{2} \mathrm{~m}^{2} \mathrm{c}^{4}}\left(\frac{1+\cos ^{2} 2 \theta}{2}\right)
$$

onde $\mathrm{I}_{\mathrm{o}}$ é a intensidade do feixe incidente e $2 \theta$ o ângulo de espalhamento da radiação, sendo a onda eletromagnética plana e polarizada.

\subsection{Espalhamento Comptom (Woolfson, 1970, Cullity, 1956).}

Há uma forma completamente diferente pela qual um elétron pode espalhar raios $\mathrm{X}$, conhecida como efeito Compton. Esse efeito ocorre quando raios X incidem sobre elétrons livres ou fracamente ligados e pode ser melhor entendido a partir da teoria corpuscular da luz. 
Assim a partir da conservação do momento e da energia da colisão do fóton com o elétron, obtemos a expressão abaixo,

$$
\Delta \lambda=0.0243(1-\cos 2 \theta)(\AA)
$$

onde $2 \theta$ é o ângulo de espalhamento e $\Delta \lambda$ é a diferença entre o comprimento de onda da radição espalhada e incidente. Assim temos que a radiação espalhada possue um comprimento de onda maior que o da radiação incidente (espalhamento inelástico), devido a transferência de energia do fóton para o elétron.

Experimentalmente encontra-se que a radiação espalhada pelos materiais consiste de duas partes. A primeira parte é aquela associada ao espalhamento Thomson e possue o mesmo comprimento de onda da radiação incidente; a segunda parte tem um comprimento de onda maior que a radiação incidente, com o aumento do comprimento de onda sendo dependente do ângulo de espalhamento.

\subsection{Espalhamento por elétrons (Cantor \& Schimmel, 1980).}

Para analisar o espalhamento de raios $\mathrm{X}$ por elétrons vamos considerar a geometria de um experimento típico de espalhamento, como aquele mostrado na figura 4.1. Nele temos um feixe raios $\mathrm{X}$ colimado incidindo sobre um elétron, localizado na origem do sistema de coordenadas

Um vetor unitário, $\mathbf{s}_{0}$, descreve a direção da radiação incidente. A direção de espalhamento é indicada por outro vetor unitário, s, e o ângulo de espalhamento é $2 \theta$. $\mathrm{Na}$ figura 4.2 , temos o vetor de espalhamento $S$, que é dado pela expressão,

$$
\mathbf{S}=\frac{\mathbf{s}-\mathbf{s}_{0}}{\lambda}
$$

A partir da figura 4.2 , vemos que o módulo $\mathbf{S}$, é função do ângulo de espalhamento, como segue,

$$
\mathbf{S}=\frac{2|\operatorname{sen} \theta|}{\lambda}
$$


$\mathrm{O}$ valor do módulo de $\mathbf{S}$ pode variar de 0 a $2 / \lambda$. Desta forma, o vetor $S$ está descrito num espaço onde cada eixo de seu sistema de coordenadas tem dimensão do recíproco da distância. Este espaço de coordenadas é chamado espaço recíproco.

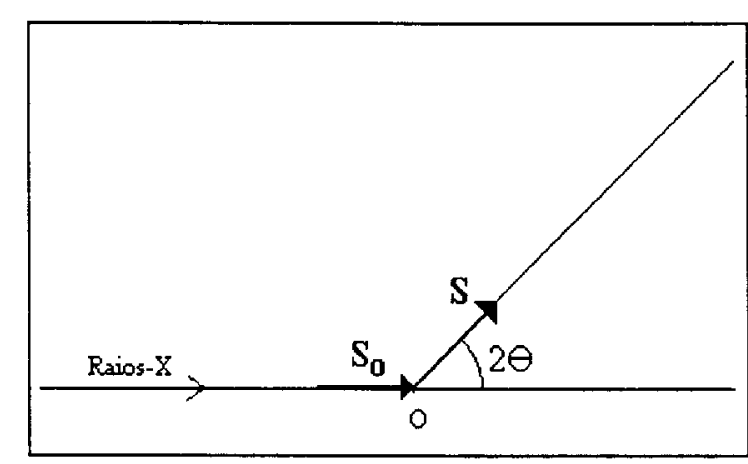

Figura 4.1. Espalhamento de raios $\mathrm{X}$ por um elétron.

\subsection{Fator de espalhamento atômico (Cantor \& Schimmel, 1980, Azároff, 1968).}

Considerando que um elétron isolado espalha raios X com intensidade I, seria de se esperar, que num átomo de $\mathrm{Z}$ elétrons teríamos uma intensidade $\mathrm{ZI}$. Porém, devido às distâncias entre os elétrons num átomo serem da ordem do comprimento de onda do raio $\mathrm{X}$, as ondas que eles espalham interferem umas com outras, de forma que só teremos uma intensidade ZI na direção de incidência do raio X. Para o espalhamento em outras direções temos interferência

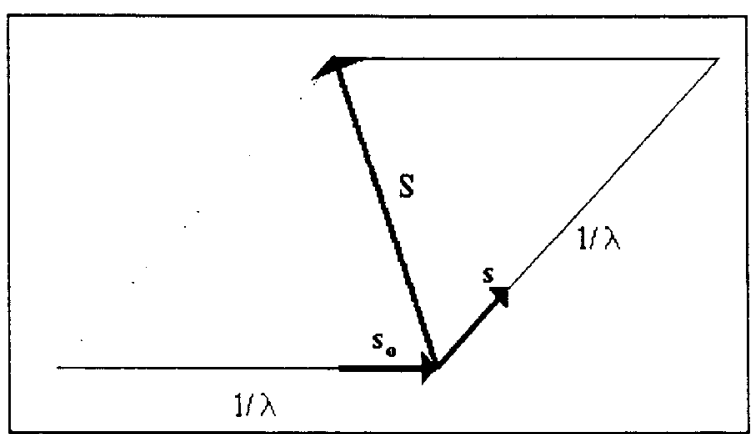

Figura 4.2. Composição do vetor de espalhamento $\mathbf{S}$.

parcialmente destrutiva, de maneira que,

a amplitude total cai com o aumento do ângulo de espalhamento. $O$ fator de espalhamento atômico é definido como a relação entre a amplitude espalhada por um átomo $\left(E_{a}\right)$ e a amplitude espalhada por um elétron $\left(E_{e}\right)$ isolado, sob condições idênticas,

$$
f=\frac{E_{a}}{E_{e}}
$$

O valor máximo de fé $\mathrm{Z}$ (número atômico do átomo) e ocorre quando os elétrons espalham em fase, na direção de incidência $(2 \theta=0)$.

O fator de espalhamento atômico também depende do comprimento de onda da 
radiação incidente. Para um valor fixo de $\theta$, f será menor para comprimentos de onda mais curtos, visto que, a diferença de caminho será maior com relação ao comprimento de onda, levando a uma maior interferência.

Considerando um átomo esférico com o seu centro coincidente com a origem do sistema de coordenadas, temos que, a onda total espalhada por um pequeno volume dv numa posição $\mathbf{r}$ relativa à onda espalhada na origem terá uma amplitude proporcional a $\rho(r) d v$ e uma fase $2 \pi r . S$, ou seja, a amplitude da onda espalhada será igual a $\rho(\mathbf{r}) \exp (2 \pi i r . S) d v$.

Consequentemente a onda total espalhada por um átomo é calculada pela soma das ondas espalhadas pelos elementos de volume $\mathrm{dv}$

$$
f(\mathbf{S})=\int_{\text {voldo atomo }} \rho(\mathbf{r}) \exp (2 \pi \mathbf{r} . \mathbf{S}) \mathrm{dv}
$$

A expressão acima representa o fator de espalhamento atômico. Curvas do espalhamento atômico para diversos átomos estão tabeladas no Volume III das Internartional Tables for $X$ Ray Crystallography.

\subsection{Espalhamento de raios}

$X$ por uma molécula

(Blundell \& Johnson,

1976; Lipson \& Taylor, 1958).

Vamos analisar agora o espalhamento de raios $\mathrm{X}$ de um conjunto de átomos colocados em

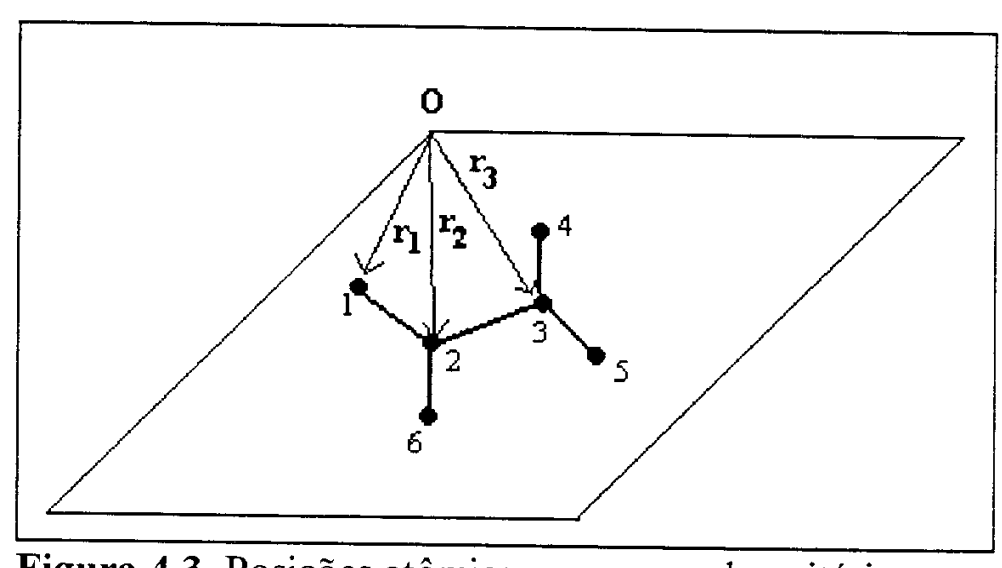

Figura 4.3. Posições atômicas em uma cela unitária.

posições definidas pelos vetores posição $\mathbf{r}_{\mathbf{i}}$.

Consideremos o átomo 1 na figura 4.3 que está a uma distância $\mathbf{r}_{1}$ da origem $(\mathrm{O})$. Este deslocamento do centro do átomo significa que a distância $\mathbf{r}$ na equação (4.4) é substituida por $\mathbf{r}+\mathbf{r}_{1}$. Assim temos que o espalhamento do átomo 1 será dado pela seguinte expressão, 


$$
\begin{gathered}
\mathrm{f}_{1}=\underset{\text { vol.do atomo }}{\int} \rho(\mathbf{r}) \exp \left(2 \pi \mathrm{i}\left(\mathbf{r}_{\mathbf{1}}+\mathbf{r}\right) \cdot \mathbf{S}\right) \mathrm{dv}= \\
=\mathrm{f} 1^{\prime} \exp \left(2 \pi \mathbf{r}_{1} \cdot \mathbf{S}\right)
\end{gathered}
$$

onde,

$$
\mathrm{f}_{\mathrm{l}^{\prime}}=\underset{\text { vol.do atomo }}{\int} \rho(\mathbf{r}) \exp (2 \pi \mathrm{i} \mathbf{r} . \mathbf{S}) \mathrm{dv} .
$$

Expressões similares podem ser obtidas para os outros átomos.

A onda total espalhada por todos os átomos é dada pela soma vetorial das contribuições de cada átomo ( figura 4.4),

$$
\mathbf{G ( S )}=\sum_{j=1}^{N} f j \exp \left(2 \pi i \mathbf{r}_{\mathbf{j}} \mathbf{S}\right) \text {. }
$$


4.7. Espalhamento de raios X por um cristal (Blundell \& Johnson, 1976; Lipson \& Taylor, 1958).

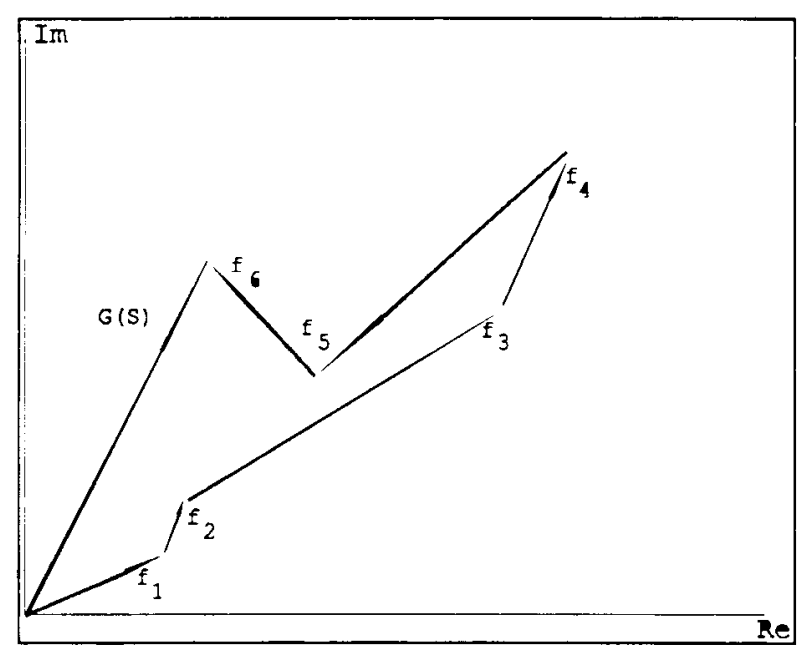

Figura 4.4. Diagrama de Argand mostrando a soma vetorial.
A fim de obter a expressão para o espalhamento por um cristal, primeiro consideramos o espalhamento de um cristal unidimensional, que é composto de um arranjo linear de celas unitárias com um espaçamento a entre elas. A amplitude total espalhadada pelo cristal será a soma das ondas espalhadas por cada cela unitária. A amplitude da onda espalhada pela primeira cela unitária relativa a origem é simplesmente $\mathbf{G}(\mathbf{S})$.

A amplitude espalhada pela segunda cela unitária relativa à mesma origem é $\mathbf{G}(\mathbf{S}) \exp (2 \pi \mathrm{ia.S})$, visto que, todas as distâncias estão deslocadas pelo vetor a. A amplitude da onda espalhada

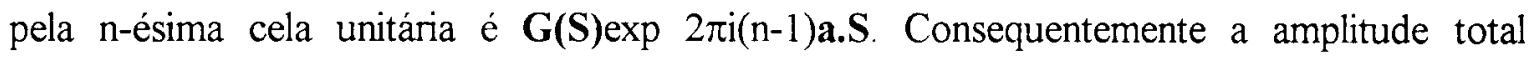
espalhada é,

$$
\mathbf{F}(\mathbf{S})=\sum_{n=1}^{T} \mathbf{G}(\mathbf{S}) \exp 2 \pi \mathrm{i}(\mathrm{n}-1) \mathbf{a} . \mathbf{S}
$$

onde $\mathrm{T}$ é o número total de celas unitárias.

A maneira que cada uma das contribuições individuais se somam pode ser vista na figura 4.5. A onda de cada cela unitária está fora de fase com sua vizinha por uma quantidade de $2 \pi$ a.S. Consequentemente, conforme o número de celas unitárias aumenta, a amplitude total espalhada, $\mathbf{F}(\mathbf{S})$, fica da mesma ordem de $\mathbf{G}(\mathbf{S})$, que para raios $X$ e muito pequena para ser observada (figura 4.5).

O espalhamento só será observado quando a diferença de fase entre as ondas espalhadas, por celas unitárias sucessivas, for um múltiplo inteiro de $2 \pi$ (figura 4.6 ), ou seja, 
$\mathbf{a} . \mathrm{S}=\mathrm{h}$, onde $\mathrm{h}$ é um número inteiro.

Sob estas circunstâncias as ondas se somam para formar uma onda espalhada mais intensa, que é proporcional em magnitude a $\mathrm{T} .|\mathbf{G}(\mathbf{S})|$. Em resumo, para uma rede unidimensional, só observamos espalhamento quando a.S $=\mathrm{h}$. Quando o problema é estendido para três dimensões, com uma cela unitária definida pelos vetores $\mathbf{a}, \mathbf{b}$ e $\mathbf{c}$, a condição para ocorrer a difração é que as condições $\mathbf{a} . \mathbf{S}=\mathrm{h}, \mathbf{b} . \mathbf{S}=\mathrm{k}$ e $\mathbf{c} . \mathbf{S}=1$ sejam simultaneamente satisfeitas. Estas condições correpondem às conhecidas equações de Laue.

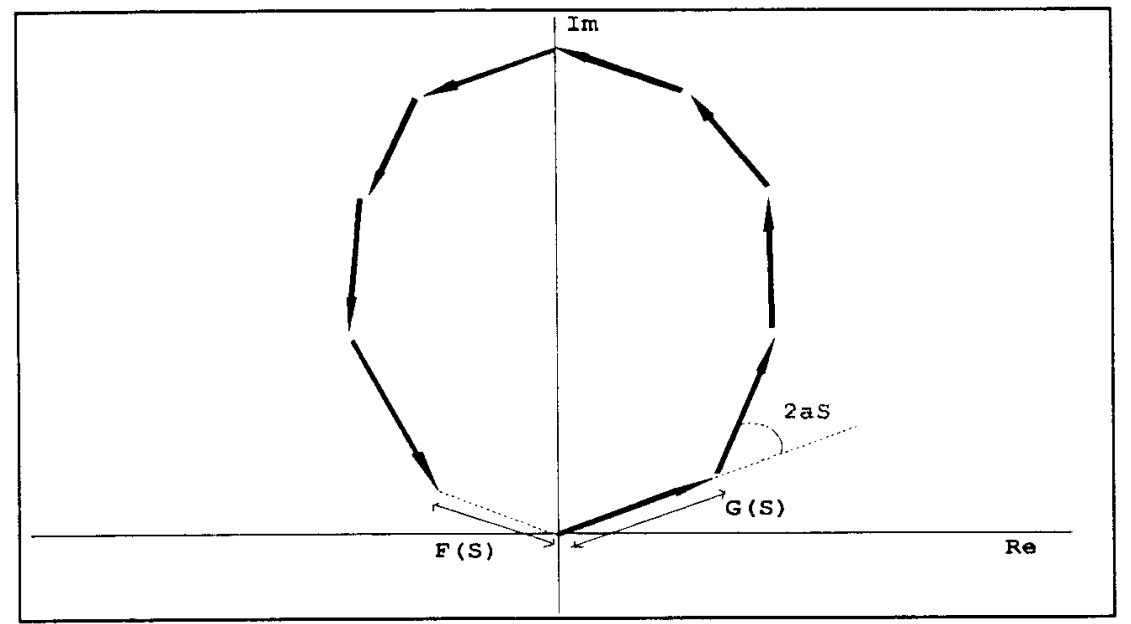

Figura 4.5. Diagrama de Argand ilustrando o espalhamento total de uma molécula num cristal.

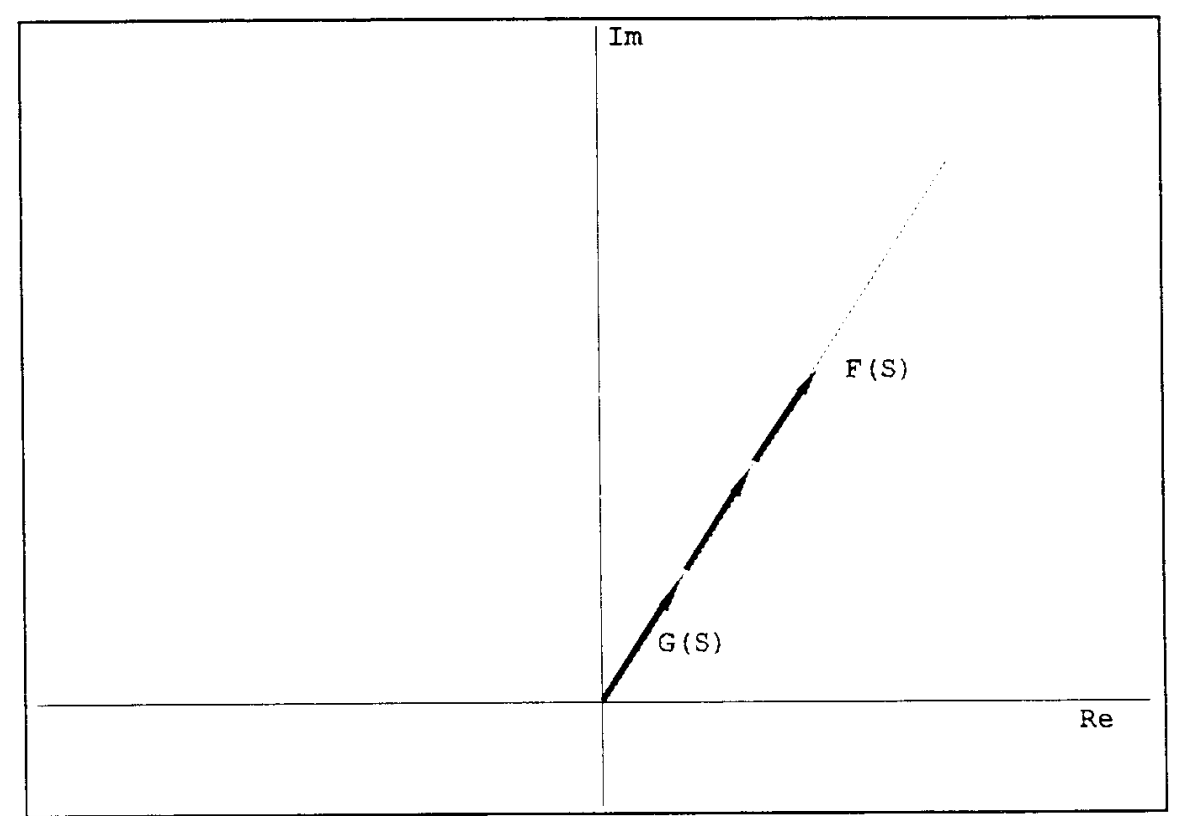

Figura 4.6. Diagrama de Argand, ilustrando a situação, onde a diferença de fase é um múltiplo inteiro de $2 \pi$. 
Assim podemos reescrever a amplitude total da seguinte forma,

$$
\mathbf{F}(\mathbf{S})=\sum_{\mathrm{j}=1}^{\mathrm{N}} f_{\mathrm{j}} \exp 2 \pi \mathrm{i}(\mathbf{r} . \mathbf{S}),
$$

onde: $\mathbf{r}_{\mathrm{j}}=\mathbf{a x}_{\mathrm{j}}+\mathbf{b y}_{\mathrm{j}}+\mathbf{c z}_{\mathrm{j}}$ e $\mathrm{x}_{\mathrm{j}}, \mathrm{y}_{\mathrm{j}}, \mathrm{z}_{\mathrm{j}}$ são as coordenadas fracionárias do j-ésimo átomo. Sendo que a constante de proporcionalidade, $\mathrm{T}$, foi omitida. As cooordenadas fracionárias $(\mathrm{x}, \mathrm{y}, \mathrm{z})$, são definidas como, $\mathrm{x}=\mathrm{X} / \mathrm{a}, \mathrm{y}=\mathrm{Y} / \mathrm{b}$ e $\mathrm{z}=\mathrm{Z} / \mathrm{c}$, onde: $\mathrm{X}, \mathrm{Y}, \mathrm{Z}$ são as coordenadas absolutas do átomo na cela unitária de eixos a,b e c.

Considerando as equações de Laue temos que,

$$
\begin{aligned}
r_{j} . S= & x_{j} a . S+y_{j} b . S+z_{j} c . S \\
& =h x_{j}+k y_{j}+z_{j},
\end{aligned}
$$

portanto,

$$
\mathbf{F}(\mathrm{hkl})=\sum_{j=l}^{N} \mathrm{f}_{\mathrm{j}} \exp 2 \pi \mathrm{i}\left(\mathrm{hx}_{j}+\mathrm{ky}_{\mathrm{j}}+\mathrm{lz}_{\mathrm{j}}\right)
$$

onde a.S, b.S e c.S foram substituidos por h,k,l no lado esquerdo da equação.

A equação (4.7) é conhecida como equação do fator de estrutura. Ela representa uma amostragem da transformada $G(S)$ nos pontos hkl do retículo recíproco. Se as posições de todos os átomos na cela unitária são conhecidas então o correspondente padrão de difração pode ser calculado. 


\subsection{Espaço recíproco (Cantor \& Schimmel, 1980).}

Para cada retículo cristalino é possível construir uma retículo recíproco, assim chamado porque muitas das suas propriedades são recíprocas às propriedades do retículo cristalino. Considerando um retículo cristalino que possua uma cela unitária definida pelos vetores $\mathbf{a}, \mathbf{b}, \mathbf{c}$ definimos uma cela unitária do retículo recíproco pelos vetores, $\mathbf{a}^{*}, \mathbf{b}^{*}, \mathbf{c}^{*}$ dados por:

$$
\begin{aligned}
\mathbf{a}^{*} & =\frac{1}{\mathrm{~V}}(\mathbf{b} \times \mathbf{c}), \\
\mathbf{b}^{*} & =\frac{1}{\mathrm{~V}}(\mathbf{c x a}), \\
\mathbf{c}^{*} & =\frac{1}{\mathrm{~V}}(\mathbf{a x} \mathbf{b}),
\end{aligned}
$$

onde $\mathrm{V}$ é o volume da cela unitária. Neste retículo recíproco podemos construir um vetor $\mathbf{H}$, desenhado a partir da origem até um ponto interno a este retículo, com coordenadas $h, k, 1$, e perpendicular ao plano do retículo cristalino cujos os índices de Miller são h,k,l, como mostra a figura 4.7. Este vetor pode ser expresso pela seguinte equação,

$$
\mathbf{H}=\mathrm{h} \mathbf{a}^{*}+\mathrm{kb}{ }^{*}+\mathrm{lc}
$$

Uma outra propriedade do vetor $\mathbf{H}$ que podemos destacar é que seu módulo é igual ao reciproco da distância interplanar,

$$
\mathrm{H}=\frac{1}{\mathrm{~d}(\mathrm{~h}, \mathrm{k}, \mathrm{l})}
$$

onde $d(h, k, l)$ é a distância interplanar $(h, k, l)$. 


\section{Para considerar as} condições em que ocorre a difração, devemos determinar a diferença de fase entre os raios espalhados em $\mathrm{A}_{1}$ e $\mathrm{A}_{2}$ (figura 4.8). Sendo $\delta$ a diferença de caminho ótico dos raios espalhados

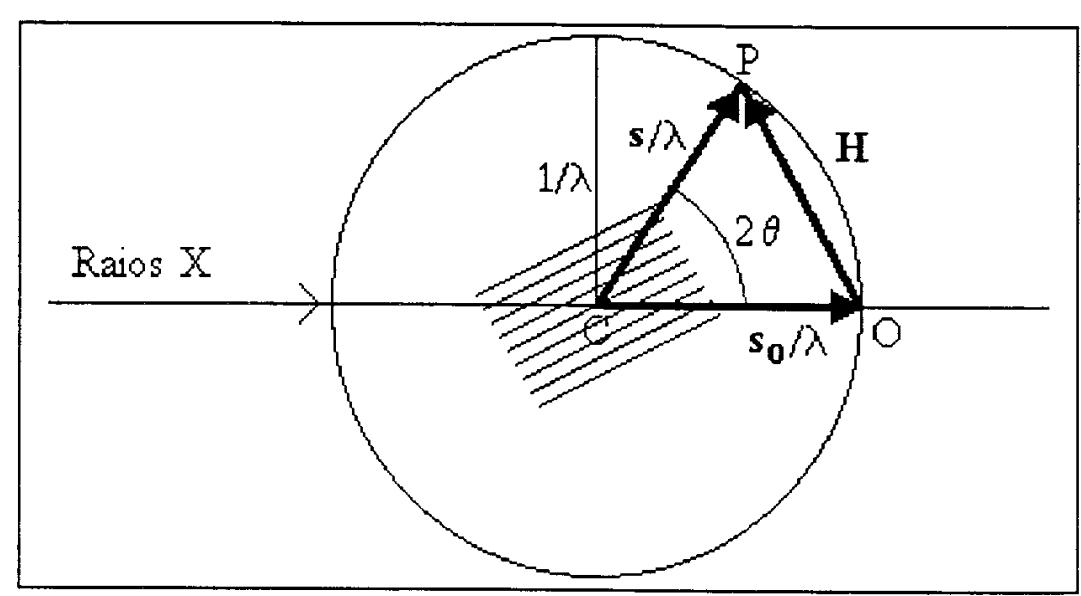

Figura 4.7. Esfera de Ewald.

por $A_{1}$ e $A_{2}$, r é o vetor posição dado por $\mathbf{r}=x \mathbf{a}+y \mathbf{b}+z \mathbf{c}$, então

$$
\delta=\mathbf{r}, \mathbf{s}-\mathbf{r} \cdot \mathbf{s}_{\mathbf{0}}=\mathbf{r} \cdot\left(\mathbf{s}-\mathbf{s}_{\mathbf{o}}\right)
$$

Assim temos a seguinte diferença de fase,

$$
\phi=\frac{2 \pi \delta}{\lambda}=2 \pi \frac{\mathbf{r} \cdot\left(\mathbf{s}-\mathbf{s}_{\mathbf{0}}\right)}{\lambda}=2 \pi \mathbf{r} . \mathbf{S}
$$

Relacionamos agora a difração com o retículo reciproco expressando o vetor $\mathbf{S}$ como um vetor desse retículo,

$$
\frac{\mathbf{s}-\mathbf{s}_{\mathbf{o}}}{\lambda}=\mathrm{h} \mathbf{a}^{*}+\mathrm{k} \mathbf{b}^{*}+\mathrm{l} \mathbf{c}^{*}
$$

Até este ponto nenhuma restrição foi feita aos índices $h, k, l$. Eles podem assumir qualquer valor, inteiro ou não, a diferença de fase fica então,

$$
\phi=2 \pi(\mathrm{xa}+\mathrm{yb}+\mathrm{zc}) .\left(\mathrm{h} \mathbf{a}^{*}+\mathrm{k} \mathbf{b}^{*}+\mathrm{l} \mathbf{c}^{*}\right) .
$$

A condição para a difração ocorrer(equações de Laue) é que o vetor $\mathbf{S}$ esteja sobre um ponto do retículo reciproco, 


$$
\mathbf{S}=\frac{\mathbf{s}-\mathbf{s}_{\mathbf{o}}}{\lambda}=\mathrm{h} \mathbf{a}^{*}+\mathrm{k} \mathbf{b}^{*}+\mathrm{l} \mathbf{c}^{*}
$$

onde h,k e l são inteiros (figuras 4.7 e 4.8).

As equações de Laue e Bragg podem ser derivadas da equação 4.17. As primeiras são obtidas a partir do produto escalar da equação pelos vetores a, b e c. Por exemplo,

$$
\text { a. } \mathbf{S}=\mathbf{a} \cdot\left(\mathrm{h}_{\mathbf{a}}{ }^{*}+\mathrm{k} \mathbf{b}^{*}+\mathrm{l} \mathbf{c}^{*}\right)=\mathrm{h}
$$

obtemos assim:

$$
\text { a. } \mathbf{S}=\mathrm{h}, \quad \mathbf{b} . \mathbf{S}=\mathrm{k}, \mathbf{c} . \mathbf{S}=1 \text {. }
$$

Conhecidas como equações de Laue (ou condições de Laue). Quando as três equações são satisfeitas, um feixe de raios $\mathrm{X}$ difratado será produzido.

Podemos considerar o feixe de raios $\mathrm{X}, \mathbf{s}$, como se fosse refletido por um conjunto de planos perpendiculares a $\mathbf{S}$. Na realidade a equação (4.17) estabelece que $\mathbf{S}$ seja

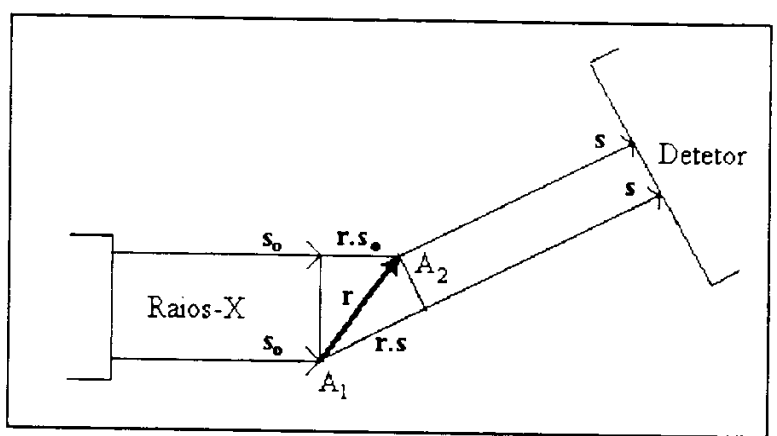

Figura 4.8. Diferença de caminho ótico perpendicular aos planos $(\mathrm{h}, \mathrm{k}, \mathrm{l})$. Sendo $\theta$ o ângulo entre $\mathbf{s}\left(\right.$ ou $\left.\mathbf{s}_{\mathbf{0}}\right)$ e esses planos. Assim temos que

$$
\frac{2 \operatorname{sen} \theta}{\lambda}=\left|\frac{\mathbf{s}-\mathbf{s}_{\mathbf{o}}}{\lambda}\right|=|\mathbf{H}|=\frac{1}{\mathrm{~d}(\mathrm{hkl})}
$$

ou

$$
\lambda=2 \mathrm{~d}(\mathrm{hkl}) \operatorname{sen} \theta
$$

As condições para difração expressas pela equação (4.17) podem ser representadas graficamente pela construção de Ewald, mostrada pela figura 4.7. O vetor $\mathbf{s}_{\boldsymbol{o}} \boldsymbol{\lambda} \lambda$ é desenhado paralelo ao feixe incidente. $\mathrm{O}$ ponto $\mathrm{O}$ é tomado como origem do retículo recíproco. Uma esfera de raio $1 / \lambda$ é desenhada em torno de C (esfera de Ewald). Assim a condição para 
ocorrer difração a partir dos planos $(h, k, 1)$ é que o ponto $P(h, k, l)$ toque a superficie da esfera de Ewald (figura 4.7), e a direção do feixe difratado (s/ $\lambda$ ) é encontrada juntando-se C a P.

\subsection{Lei de Friedel (Blundell \& Johnson, 1976)}

A lei de Friedel relaciona uma reflexão de índices hkl com a reflexão -h,-k,-l. A relação é deduzida da seguinte maneira,

$$
\mathbf{F}(h k l)=\sum_{j=1}^{N} f_{j} \exp 2 \pi i\left(h x j+k y_{j}+1 z j\right)
$$

e

$$
F(-h,-k,-l)=\sum_{j=1}^{N} f_{j} \exp 2 \pi i\left(-h x j-k y_{j}-l z j\right),
$$

portanto, temos que os módulos são iguais; $F(h k l)=F(-h,-k,-l)$. $E$ as fases(a) seguem a seguinte relação, $\alpha(\mathrm{hkl})=-\alpha(-h,-k,-1)$. Consequentemente o padrão de difração registrado será centrossimétrico $(I(h, k, l)=I(-h,-k,-1))$, mesmo que a estrutura não possua um centro de simetria. Devios da lei de Friedel ocorrem no caso de espalhamento anômalo e em tais casos as pequenas diferenças podem ser usadas para fornecer informações sobre a fase.

\subsection{Densidade eletrônica (Sherwood, 1976)}

O padrão de difração é a transformada de Fourier da densidade eletrônica da estrutura e inversamente a densidade eletrônica da estrutura é a transformada de Fourier do padrao de 
difração. Para mostrar isto, podemos reescrever a equação do fator de estrutura (equação 4.7)

em termos de uma integral sobre o volume da cela unitária(V)

$$
\begin{gathered}
\mathbf{F}(\mathbf{S})=\sum_{\mathrm{j}=1}^{\mathrm{N}} \mathrm{f}_{\mathrm{j}} \exp 2 \pi \mathrm{i}\left(\mathbf{r}_{\mathrm{j}} \cdot \mathbf{S}\right) \\
=\int_{\mathrm{V}} \rho(\mathbf{r}) \exp 2 \pi \mathrm{i}(\mathbf{r} \cdot \mathbf{S}) \mathrm{d} \mathrm{v},
\end{gathered}
$$

onde $\mathbf{S}$ é usado para representar a posição no espaço recíproco e $\rho(\mathbf{r})$ é densidade eletrônica. Multiplicando ambos os lados por (exp-2 $\left.2 \mathrm{i}\left(\mathbf{r}^{\prime} \cdot \mathbf{S}\right)\right)$ e integrando sobre o volume recíproco $\left(\mathrm{V}^{*}=1 / \mathrm{V}\right)$, temos que,

$$
\rho(\mathbf{r})=\int_{\mathbf{V}^{*}} \mathbf{F}(\mathbf{S}) \exp -2 \pi \mathrm{i}(\mathbf{r} \cdot \mathbf{S}) \mathrm{d} v^{*}
$$

onde $\mathrm{dv}^{*}$ é o elemento de volume no espaço recíproco.

A integração pode se substituida por uma somatória, visto que, $\mathbf{F}(\mathbf{S})$ não é contínuo e é diferente de zero somente nos pontos do retículo recíproco. Consequentemente,

$$
\rho(\mathrm{xyz})=\frac{1}{\mathrm{~V}} \sum_{h=-\infty}^{\infty} \sum_{k=-\infty}^{\infty} \sum_{l=-\infty}^{\infty} \mathbf{F}(\mathrm{hkl}) \exp -2 \pi \mathrm{i}(\mathrm{hx}+\mathrm{ky}+\mathrm{lz})
$$

Desta forma se os fatores de estrutura, $\mathbf{F}(\mathrm{hkl})$, são conhecidos para todas as reflexões, hkl, então a densidade eletrônica, $\rho(x y z)$, pode ser calculada para cada ponto xyz, na cela unitária. A densidade eletrônica representa a estrutura do cristal.

\subsection{O problema da fase (Blundell \& Johnson, 1976).}

Para calcular a densidade eletrônica é necessário o conhecimento do módulo, $\mathrm{F}(\mathrm{hkl})$, e 
da fase, $\alpha(\mathrm{hkl})$, do fator de estrutura. Isto é enfatizado quando reescrevemos a equação 4.22 , como segue,

$$
\rho(\mathrm{xyz})=\frac{1}{\mathrm{~V}} \sum_{h=-\infty}^{\infty} \sum_{k=-\infty}^{\infty} \sum_{l=-\infty}^{\infty} \mathrm{F}(\mathrm{hkl}) \exp \mathrm{i} \alpha(\mathrm{hkl}) \exp -2 \pi \mathrm{i}(\mathrm{hx}+\mathrm{ky}+\mathrm{lz})
$$

Durante um experimento de difração de raios $\mathrm{X}$, só se regitram as intensidades, sendo que toda a informação sobre a fase é perdida. Portanto é impossível determinar a estrutura diretamente das medidas do padrão de difração, visto que parte da informação está perdida. $O$ problema da determinação da fase é o problema básico em qualquer determinação de estrutura. 


\section{CAPÍtulO 5}

\section{PREPARO E COLETA DE DADOS DE DIFRAÇÃO DE RAIOS X DOS CRISTAIS DE CDK2 EM COMPLEXO COM INIBIDORES}

\subsection{Introdução.}

Discutiremos neste capítulo os métodos utilizados para a co-cristalização, embebição (soaking) e coleta de dados dos cristais de complexos binários de CDK2 com inibidores. Descreveremos os passos seguidos para a montagem e coleta de dados dos cristais utilizando-se o equipamento RAXIS-II C da Rigaku e apresentaremos os procedimentos utilizados para evitar danos por radiação no cristal.

\subsection{Embebição (soaking) e co-cristalização de complexos binários CDK2 com dois} inibidores (Azevedo et al., 1996, Kim et al., 1996).

Como foi discutido no capítulo 1 a quinase dependente de ciclina 2 (CDK2) é uma proteina central para o controle da progressão do ciclo celular e inibidores desta quinase apresentam atividade anti-cancerígena (Kaur et al., 1992). Contudo, ao iniciarmos este trabalho o entendimento da base molecular da interação entre a CDK2 com inibidores ainda estava por ser elucidado. Para se entender melhor o mecanismo de inibição da CDK2 se fazia necessária a determinação da estrutura tridimensional da CDK2 em complexo com seus inibidores. Para isto seguimos duas metodologias. A primeira de cocristalização da CDK2 com o inibidor e outra de soaking do inibidor nos cristais de CDK2. Os inibidores testados neste estudo estão mostrados na figura 5.1.

Para a co-cristalização usamos o método da matriz esparsa descrito na seção 3.11, sendo que antes de prepararmos as gotas de cristalização adicionávamos os inibidores a uma solução de CDK2 com concentração de $10 \mathrm{mg} / \mathrm{ml}(0,3 \mathrm{mM})$, uma hora antes de se montar os experimentos de cristalização. A concentração molar dos inibidores era de aproximadamente 3 vezes a concentração molar da proteína, ou seja, aproximadamente 1 mM. Procedemos assim para que se tivesse um boa concentração de CDK2 ligada ao inibidor nas gotas de cristalização. Além de se usar o método da matriz esparsa para cocristalizar CDK2 com inibidores, também utilizamos as condições originais de 
cristalização da CDK2 (Rosenblatt et al., 1993) para se tentar obter co-cristais. Tentamos obter co-cristais de CDK2 com todos os inibidores mostrados na figura 5.1. Na maioria dos experimentos com diferentes inibidores não se obteve co-cristais, com excessão dos co-cristais de CDK2-Roscovitine. Devido ao pouco sucesso dos experimentos de cocristalização procedemos aos experimentos de embebição.

Flavopiridol<smiles>C[NH+]1CCC(c2c(O)cc(O)c3c(=O)cc(-c4ccccc4Cl)oc23)C(O)C1</smiles>

$\mathbf{L 8 5 8 0 3 7}$<smiles>CCc1cc(=O)c2c(O)cc(O)c(C3CC[NH+](C)CC3O)c2o1</smiles>

Roscovitine

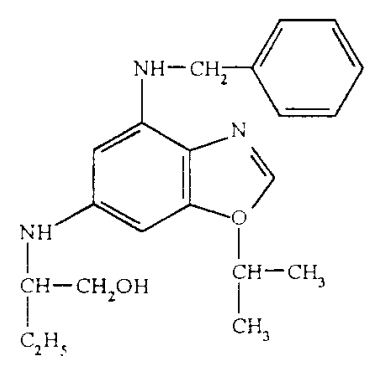

Descloro-flavopiridol (L868276)<smiles>C[NH+]1CCC(c2c(O)cc(O)c3c(=O)cc(-c4ccccc4)oc23)C(O)C1</smiles>

L857991<smiles>CCc1cc(=O)c2c(O)cc(O)c(C3CC[NH+](C)CC3O)c2o1</smiles>

2-(3-hidroxipropil amino)-6-benzil amino-9-isopropil purina

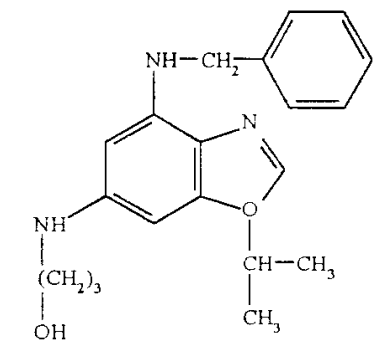

L868199<smiles>C[NH+]1CCC(c2c(O)cc(O)c3c(=O)cc(-c4ccc(Br)cc4)oc23)C(O)C1</smiles>

Butyrolactone

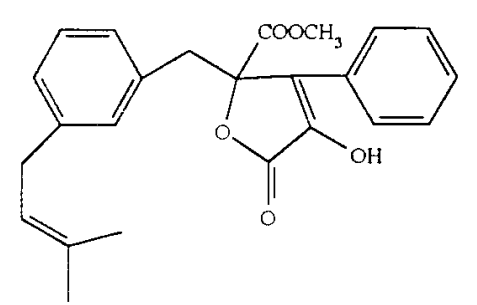

2-D,L-(2-hidroxipropil amino)-6-benzil amino-9-isopropil purina<smiles>CC(O)CNc1cc(NCc2ccccc2)c2ncoc2c1</smiles>

Figura 5.1. Estrutura dos inibidores de CDK2 estudados nesta tese. 
Anterior à embebição cristalizamos a CDK2 nas condições originais (Rosenblatt et al., 1993) e transferimos os cristais de CDK2 para gotas de cristalização de $20 \mu$ de uma solução $10 \mathrm{mM}$ de inibidor em tampão 0,2M Hepes ( $\mathrm{pH} 7,4)$, o mesmo tampão usado para cristalização de CDK2 (Rosenblatt et al., 1993). Usando esta concentração de inibidores tivemos que a maioria dos cristais de CDK2 se dissolviam, após poucos dias de exposição à solução de inibidores. Reduzimos a concentração molar dos inibidores para $1 \mathrm{mM}$ e assim foi possível coletar dados dos complexos de CDK2 com todos os inibidores mostrados na figura 5.1.

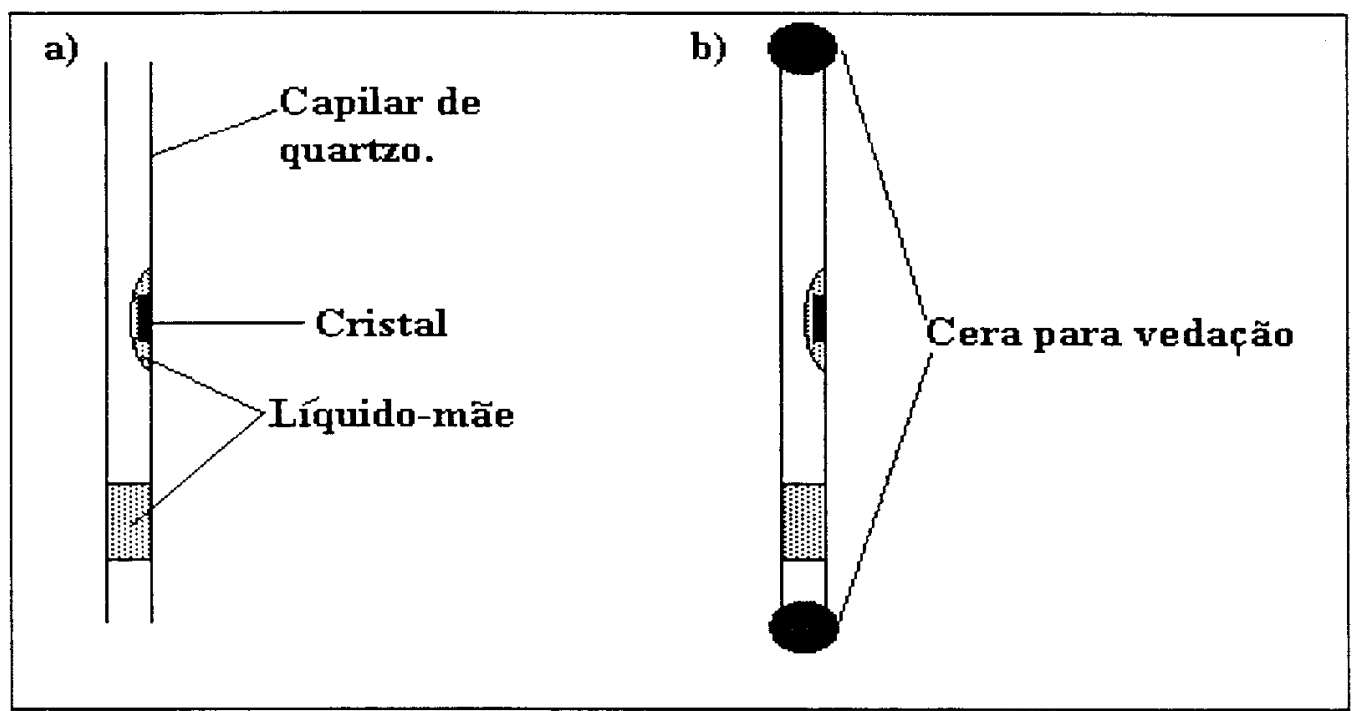

Figura 5.2. Capilar de quartzo. a) Capilar de quartzo após inserção do cristal e líquido-mãe, b) capilar após vedação com cera.

\subsection{Montagem dos cristais do complexo CDK2-Roscovitine.}

Os cristais de CDK2 de dimensões $(0,2 \mathrm{~mm} \times 0,3 \mathrm{~mm} \times 0,3 \mathrm{~mm})$ e forma de paralelepípedo ou cunha foram embebidos numa solução de 1,0 mM Roscovitine $(0,2 \mathrm{M}$ Hepes pH 7,4) por 48 horas, após este período selecionamos um cristal e por sucção este cristal foi inserido num capilar de quartzo de $0,5 \mathrm{~mm}$ de diâmetro. $\mathrm{O}$ excesso de líquidomãe em volta do cristal no interior do capilar pode ser eliminado usando-se pequenas fitas 
de papel absorvente, tomando-se cuidado para não se absorver todo o líquido-mãe em volta do cristal, o que poderia ressecá-lo. Este excesso de líquido é eliminado para evitar que o cristal se movimente durante a coleta de dados. Devido ao fato de que cristais de macromoléculas biológicas possuírem um alto conteúdo de solvente, entre $20 \%$ e mais de $80 \%$ (seção 3.1), se faz necessário que os cristais de macromoléculas biológicas sejam mantidos em um ambiente saturado de solvente, mesmo durante a coleta de dados de difração de raios $X$, caso contrário, os cristais ressecam e por fim perdem a cristalinidade. Para prevenir ressecamento dos cristais coloca-se um pouco do líquido-mãe da gota de onde se obteve o cristal no interior do capilar, sem contudo tocar o cristal com este líquido, como mostra a figura 5.2a. Uma vez inserido o cristal e o liquido mãe no capilar de quartzo é feita a vedação de ambas as extremidades do capilar para evitar a evaporação do líquido mãe (figura 5.2b). Esta vedação é feita derretendo-se uma pequena quantidade de cera em ambas as extremidades do capilar, tomando-se cuidado para não esquentar demais o capilar. Uma vez feito isto, o capilar com o cristal está pronto para ser colocado numa cabeça goniométrica e levado ao RAXIS-II C para a montagem, alinhamento e coleta de dados.

\subsection{Danos por radiação ( Drenth, 1994).}

Cristais de macromoléculas biológicas sofrem danos quando expostos aos raios $\mathrm{X}$. Os fótons de raios $\mathrm{X}$ causam a formação de radicais livres no cristal o que leva a reações químicas entre estes radicais e partes da macromolécula responsáveis pela estrutura cristalina, ou seja, ligações fracas, como ligações de hidrogênio e van der Waals, são quebradas. Para se minimizar estes danos causados pela radiação coleta-se dados dos cristais a baixa temperatura. Procedendo-se desta forma, minimizam-se os danos por radiação, possibilitando a coleta de dados por mais longos periodos. O procedimento de se coletar cristais a baixíssimas temperaturas, próximas ou iguais à temperatura do nitrogênio líquido, é conhecido como crio-cristalografia e tem se tornando de uso cada vez mais frequente, principalmente em fontes síncrotrons, devido a alta intensidade do feixe de raios $\mathrm{X}$ destas fontes. 


\subsection{Crio-cristalografia.}

A crio-cristalografia fornece um meio de aumentar a vida útil de alguns cristais de macromoléculas biológicas, o que permite a coleta de um conjunto completo de dados de difração usando-se um único cristal.

a)

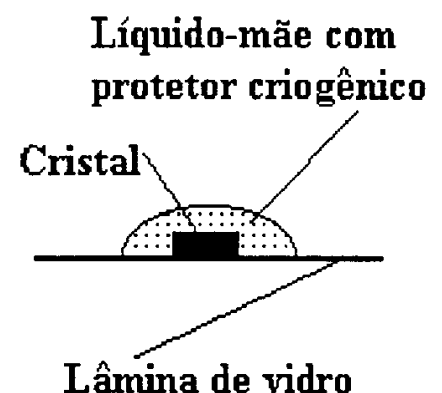

b)

Cabeça goniométrica

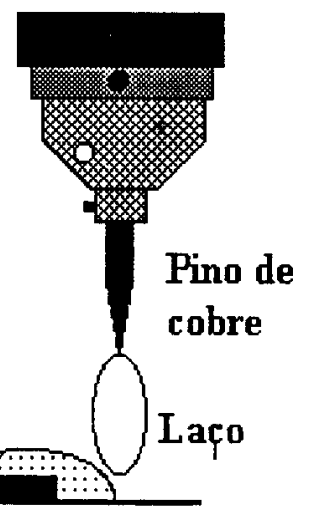

c)

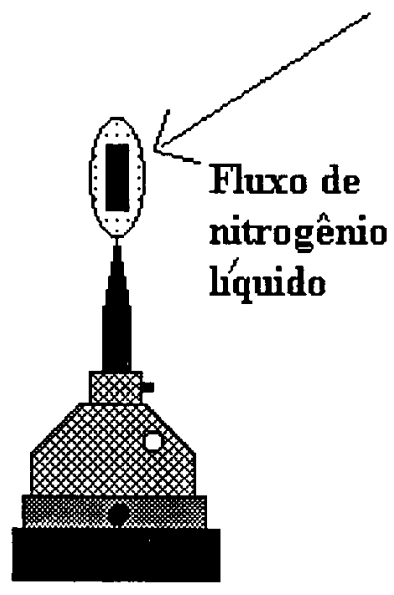

Figura 5.3. Montagem do cristal. a) Cristal imerso no líquido-mãe e protetor criogênico, b) cabeça goniométrica com o pino de cobre com laço pegando o cristal, c) cristal congelado no fluxo de nitrogênio líquido.

Contudo, para a coleta de dados de um cristal à baixíssimas temperaturas, se faz necessário o uso de um protetor criogênico, pois se o resfriamento do cristal se fizer no líquido mãe pode haver formação de gelo, o que é indesejável para a coleta de dados de difração de raios $X$, visto que, a presença de gelo irá acrescentar padrões de difração de policristais de gelo ao padrão de difração do cristal da macromolécula. Assim podemos dividir o processo de crio-cristalografia nos seguintes passos:

i) Tranfere-se o cristal para um protetor criogênico, que quando resfriado em nitrogênio líquido, não irá favorecer a formação de cristais de gelo (figura 5.3a). Os protetores criogênicos mais frequentemente usados são o etileno glicol, algumas vezes em 
combinação com PEG para aumentar a estabilidade do cristal, MPD, etanol e glicerol. Muitos destes solventes podem destruir o cristal, por isso, recomenda-se testar diversos protetores criogênicos. Pode-se também adicionar o protetor criogênico diretamente ao liquido-mãe com os cristais, em pequenos passos, até que se atinja uma concentração de aproximadamente $50 \%$ de protetor criogênico na gota. Mesmo este processo de se adicionar o protetor criogênico à gota de cristalização em pequenos passos pode destruir o cristal e um método alternativo é colocar uma gota de $1 \mu \mathrm{l}$ de protetor criogênico ao lado da gota com os cristais a serem congelados, e ligar as duas gotas com uma ponte feita com uma fita estreita ( por volta de $1 \mathrm{~mm}$ de largura, ou menor) de papel de filtro. A tensão superficial maior na menor gota de protetor criogênico irá empurrar lentamente o protetor criogênico através da ponte de papel de filtro até a gota de cristalização. Antes de se colocar o cristal diretamente no nitrogênio liquido, recomenda-se testar somente a solução do protetor criogênico mais líquido-mãe para se ter certeza que não haverá formação de gelo. Isto se faz pegandose uma pequena quantidade do líquido-mãe com protetor criogênico usando-se o laço (montado no pino de cobre) e inserindo-se o pino no nitrogênio líquido. Caso ocorra formação de gelo na solução do laço testada deve-se aumentar a concentração do protetor criogênico presente na gota de cristalização, e novamente testar no nitrogênio líquido, até que se consiga uma concentração de protetor criogênico suficiente para evitar a formação de gelo. Usando-se este procedimento evita-se o desperdício de um bom cristal, que poderia perder-se com a formação de gelo ao ser exposto ao nitrogênio liquido

ii) Uma vez tenha-se o cristal imerso no protetor criogênico apropriado, tranfere-se o cristal para um pino de cobre com um laço que irá manter o cristal (figura 5.3b). Este pino de cobre com o laço deve estar fixo numa cabeça goniométrica, e estar previamente alinhado com o feixe de raio $X$, para se evitar excesso de manuseio da cabeça goniométrica com o cristal em condições criogênicas. O laço, usado para prender o cristal, deve ser feito de um material que resista às baixas temperaturas. No Laboratório de Biocristalografica de Berkeley, usa-se uma fibra de pêlo de alpaca, mas 
outros tipos de fibras poliméricas podem ser usadas. A tensão superficial do protetor criogênico irá mater o cristal no laço, de forma que, podemos agora resfriá-lo.

iii) Um fluxo de nitrogênio líquido montado no equipamento de raios $\mathrm{X}$ (figura 5.4) fornece as condições de baixa temperatura necessárias para a coleta de dados. O fluxo de nitrogênio líquido é interrompido temporariamente para se posicionar a cabeça goniométrica, previamente alinhada, em seu suporte, e uma vez posicionada, libera-se o fluxo de nitrogênio líquido diretamente sobre o laço com o cristal, o que irá formar um gelo vítreo em torno do cristal. Tal processo de resfriamento é chamado flashfreezing (figura 5.3c). O gelo vítreo formado não produz padrão de difração, embora

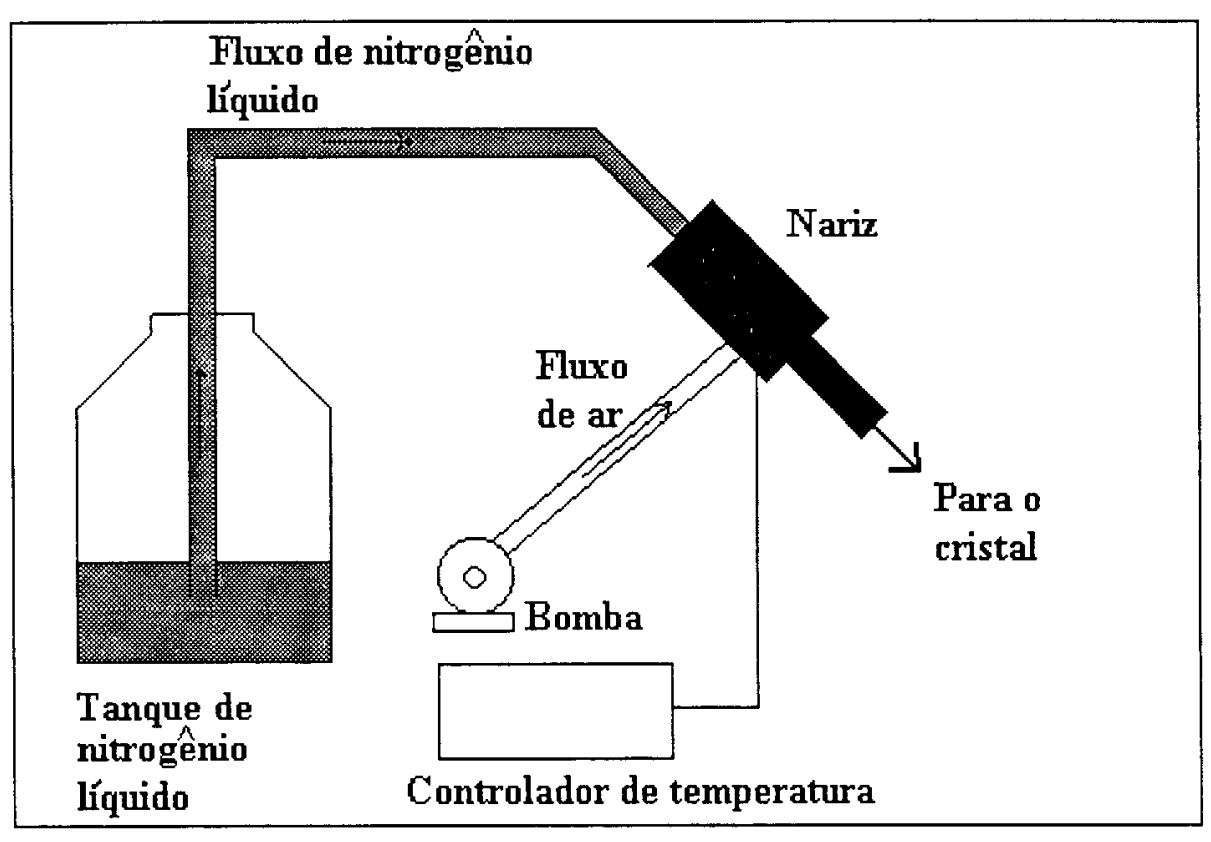

Figura 5.4. Diagrama esquemático de um sistema criogênico. possa absorver raios $\mathrm{X}$.

\section{O}

diagrama esquemático do equipamento criogênico está mostrado na figura 5.4. Nele temos o tanque de nitrogênio líquido, bomba, controlador de

temperatura, e nariz. A bomba injeta ar comprimido no nariz efetuando-se uma mistura ar mais nitrogênio líquido que irá determinar a temperatura do fluxo de saida do nariz. A composição desta mistura é controlada pelo controlador de temperatura. As figuras 5.5. e 5.6. mostram os sistemas de coleta de dados resfriados pelo sistema da OXFORD CRYOSYSTEMS nos laboratórios de Berkeley (fonte convencional de ânodo rotatório) e Brookhaven (fonte sincrotron) 


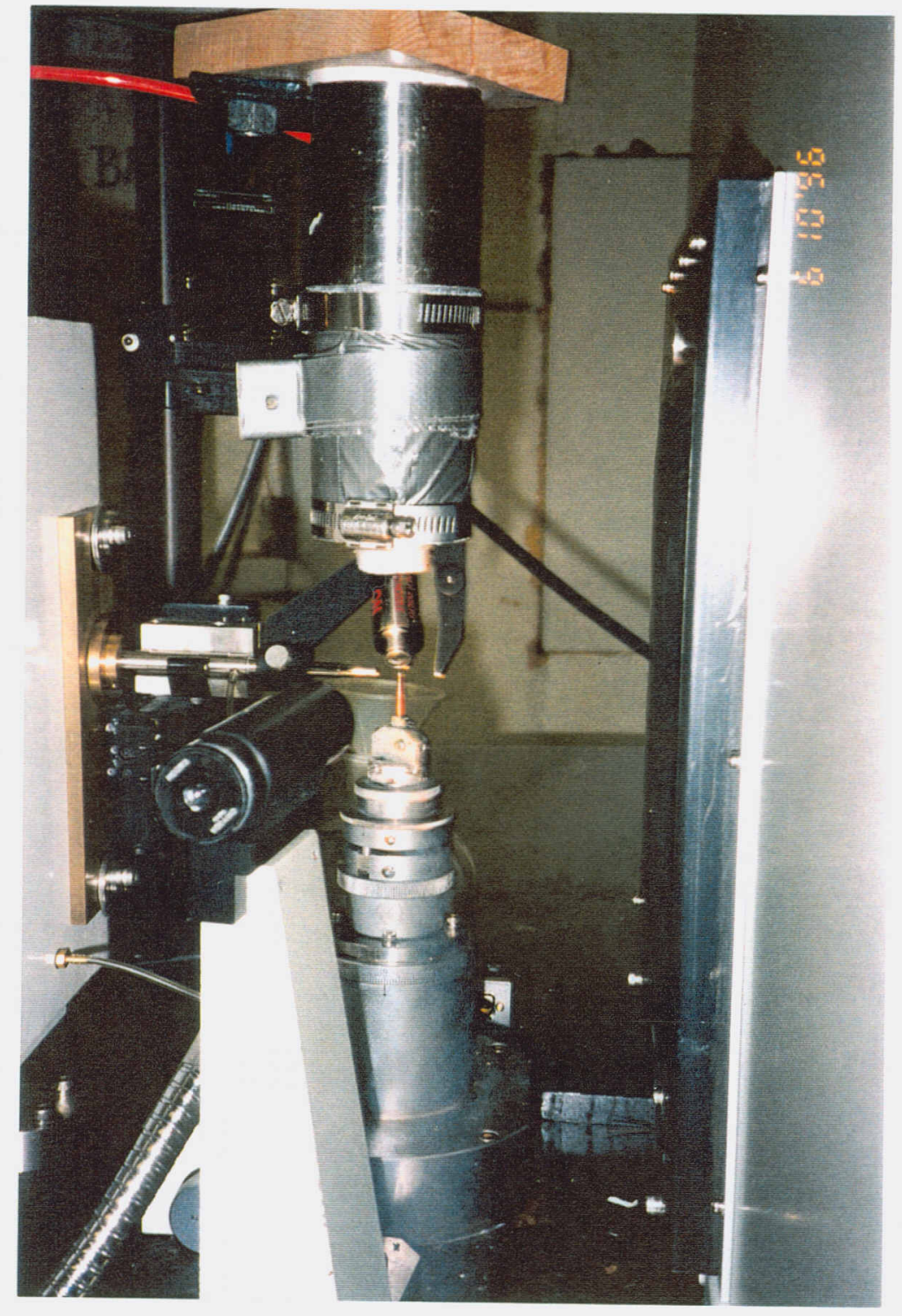

Figura 5.5. Sistema criogênico instalado em Berkeley. Visão parcial do RAXIS-II C da Rigaku instalado na University of California at Berkeley USA com o nariz do sistema de 
regrigeração da OXFORD CRYOSYSTEMS próximo ao pino de cobre com o cristal(1996)

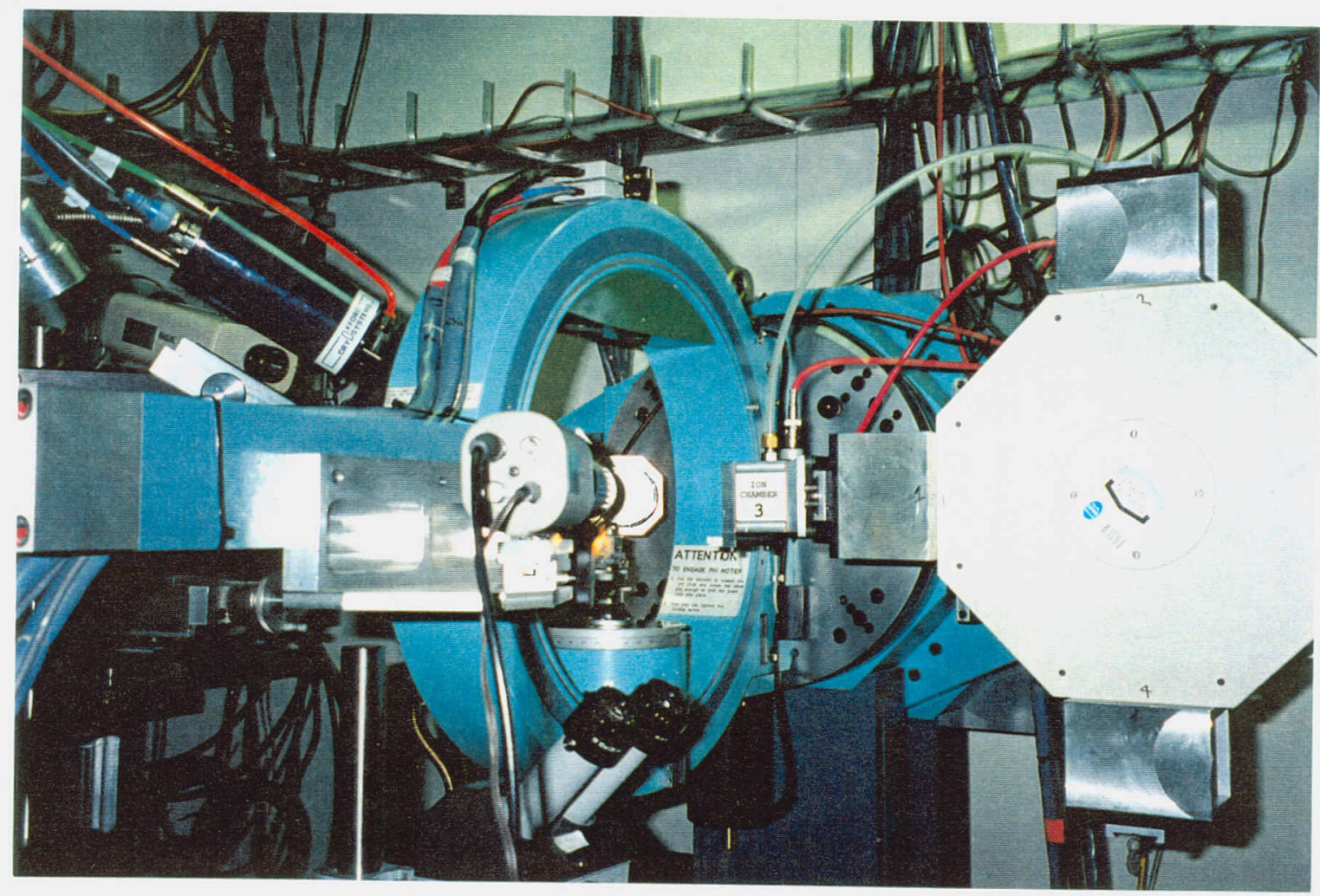

Figura 5.6. Sistema criogênico instalado em Brookhaven. Visão do sistema de refrigeração OXFORD CRYOSYSTEMS montado aa fonte de luz sincrotron em Brookhaven (USA) (1995).

Os dados de difração dos cristais de CDK2-Flavopiridol, CDK2-DFP, CDK2L868199, CDK2-L858037, CDK2-L857991 e CDK2-Butyrolactone foram coletados no 
sistema mostrado na figura 5.5., numa temperatura de $100 \mathrm{~K}$, usando $35 \%$ de MPD adicionado ao líquido-mãe como protetor criogênico. Também foram coletados dados de difração de raios X para os cristais de CDK2-Flavopiridol usando-se fonte síncrotron em Brookhaven ( figura 5.6)

\subsection{Sistema de coleta de dados RAXIS-IIC ( Sato et al., 1992).}

Para a coleta de dados dos cristais dos complexos binários de CDK2 com inibidores, usamos o sistema RAXIS-IIC instalado no laboratório de biocristalografia de Berkeley.

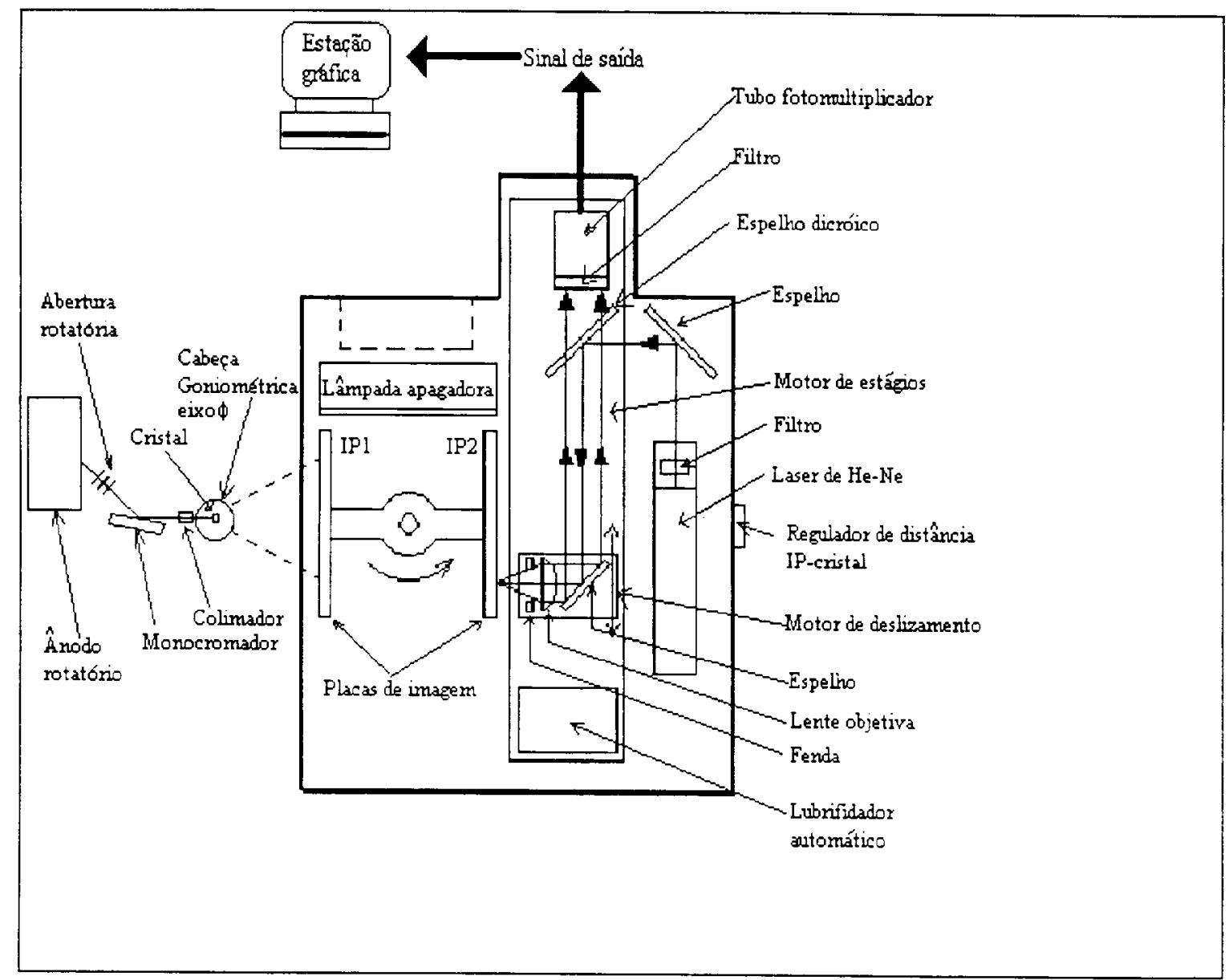

Figura 5.7. R-AXIS IIC. Diagrama esquemático do difratômetro R-AXIS IIC com sistema ótico colimador-monocromador (Sato et al., 1992) 
$\mathrm{O}$ sistema completo conta com uma fonte de raios $\mathrm{X}$ de ânodo rotatório, uma abertura rotatória sincronizada, um goniômetro (eixo $\phi$ ), um cristal monocromador, um colimador, duas placas de imagem( IP image plate) com 200 × $200 \mathrm{~mm}$, lâmpadas apagadoras, um laser He-Ne, uma fotomultiplicadora, e uma interface (SCSI) que liga o sistema a uma estação gráfica que controla o RAXIS-IIC. Um outro instrumento que pode ser adicionado ao R-AXIS IIC, além do sistema criogênico já descrito, é um conjunto de espelhos focalizadores. Este acessório é especialmente útil para coleta de dados de cristais com parâmetros de cela unitária muito grandes, maiores que $150 \AA$ (seção 5.6.3).

Um desenho esquemático do difratômetro R-AXIS IIC está mostrado na figura 5.7. A geometria de difração do sistema é basicamente aquela da câmara de oscilação de Arndt-Wonacott ( Arndt \& Wonacott, 1977), exceto que o cristal é girado em torno de um eixo vertical. Esta configuração deixa espaço livre para instalarem dispositivos para manter baixas temperaturas sobre a cabeça goniométrica. A abertura rotatória sincronizada é desenhada para responder rapidamente, dentro de 0,04 s, no início e no final da oscilação do ângulo $\phi$ do cristal, o que evita exposição não desejada antes e após o movimento do cristal.

A distância cristal-placa de imagem é variável, de 55 a $200 \mathrm{~mm}$. A unidade com as placas de imagem podem ser transladadas ao longo da direção do feixe incidente. A mais alta resolução possivel, usando-se radiação $\mathrm{Cu} \mathrm{K \alpha}$ é de $1,51 \AA$, quando a distância-cristal placa de imagem é de $55 \mathrm{~mm}$.

Uma imagem digitalizada ocupa aproximadamente 8 Mbyte e é transferida à estação de trabalho via uma interface SCSI ( Small Computer System Interface).

Uma par de placas de imagem (IP) é usado no sistema de maneira que enquanto uma IP está sendo lida, a outra IP está na posição de exposição registrando a próxima imagem. Após a exposição/leitura, as duas IPs são giradas de $90^{\circ}$ e a imagem latente residual que ainda está sobre a IP após a leitura é apagada usando-se lâmpadas apagadoras. O uso interligado de duas IPs possibilita uma coleta de dados quase continua, desde que, o tempo de exposição de uma imagem seja maior que o tempo de leitura da mesma.

As principais partes do goniômetro R-AXIS IIC estão descritas a seguir. 


\subsection{1. Ânodo rotatório (McRee, 1993).}

Os raios $\mathrm{X}$ são produzidos quando elétrons acelerados colidem contra um alvo metálico. Para se acelerar estes elétrons, num sistema de ânodo rotatório, usam-se altavoltagens, na faixa de $40 \mathrm{a} 50 \mathrm{kV}$ e correntes de até $160 \mathrm{~mA}$, o que leva a uma potência de até $8 \mathrm{~kW}$. Um fator limitante na construção de qualquer gerador de raios $\mathrm{X}$ é quanto calor pode ser dissipado do alvo metálico. No ânodo rotatório o feixe de elétrons incide sobre uma roda girante (figura 5.8), o que evita a concetração de calor em um único ponto, além

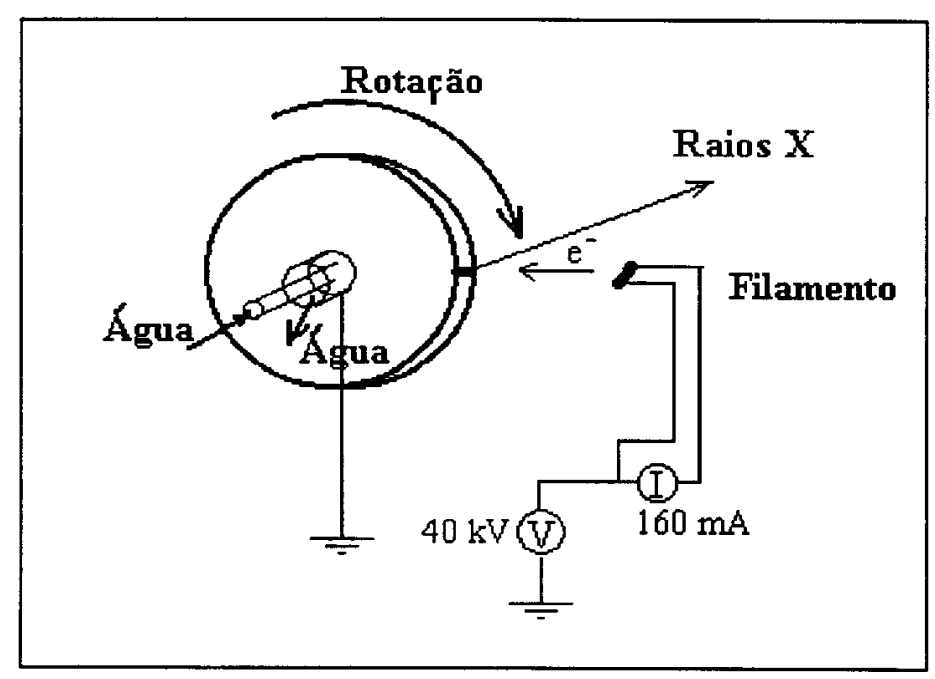
disso, exite um fluxo de água circulante para o resfriamento do alvo. O metal do alvo determina que comprimento de onda característico será emitido. O metal mais usado é o cobre, que emite raios $\mathrm{X}$ com comprimento de onda de $1,5418 \AA\left(\mathrm{CuK}_{\alpha}\right)$.

Figura 5.8. Diagrma esquemático de um ânodo rotatório.

\subsubsection{Cristal monocromador (Giacovazzo, 1992).}

$\mathrm{O}$ cristal monocromador é utilizado para se produzir um feixe de raios $\mathrm{X}$ com uma estreita distribuição de comprimentos de onda. A equação de Bragg (equação 4.21) mostra que quando radiação com diferentes comprimentos de onda incide sobre um cristal, feixes difratados são observados a diferentes ângulos de espalhamento $(\theta)$, conforme o comprimento de onda $\lambda$. Assim, selecionar um determinado ângulo de espalhamento, é equivalente a escolher um particular comprimento de onda do espectro 
incidente sobre o cristal. No sistema R-AXIS IIC usado neste trabalho utiliza-se cristal monocromador de grafite.

\subsubsection{Espelhos focalizadores (McRee, 1993).}

Raios X podem ser focalizados por deflexão a baixos ângulos usando-se espelhos curvos (figura 5.9). Dois espelhos são normalmente utilizados, um no plano horizontal e um no plano vertical. A maior vantagem destes espelhos é que os raios $\mathrm{X}$ podem se focalizados, aumentando o brilho, o que permite obter melhores conjuntos de dados para cristais com celas unitárias muito grandes $(>150 \AA)$, que possuem pontos de difração muito próximos. Um sistema que usa este tipo de espelhos focalizadores de raios $\mathrm{X}$ é comercializado pela MSC ( Molecular Structure Co.).

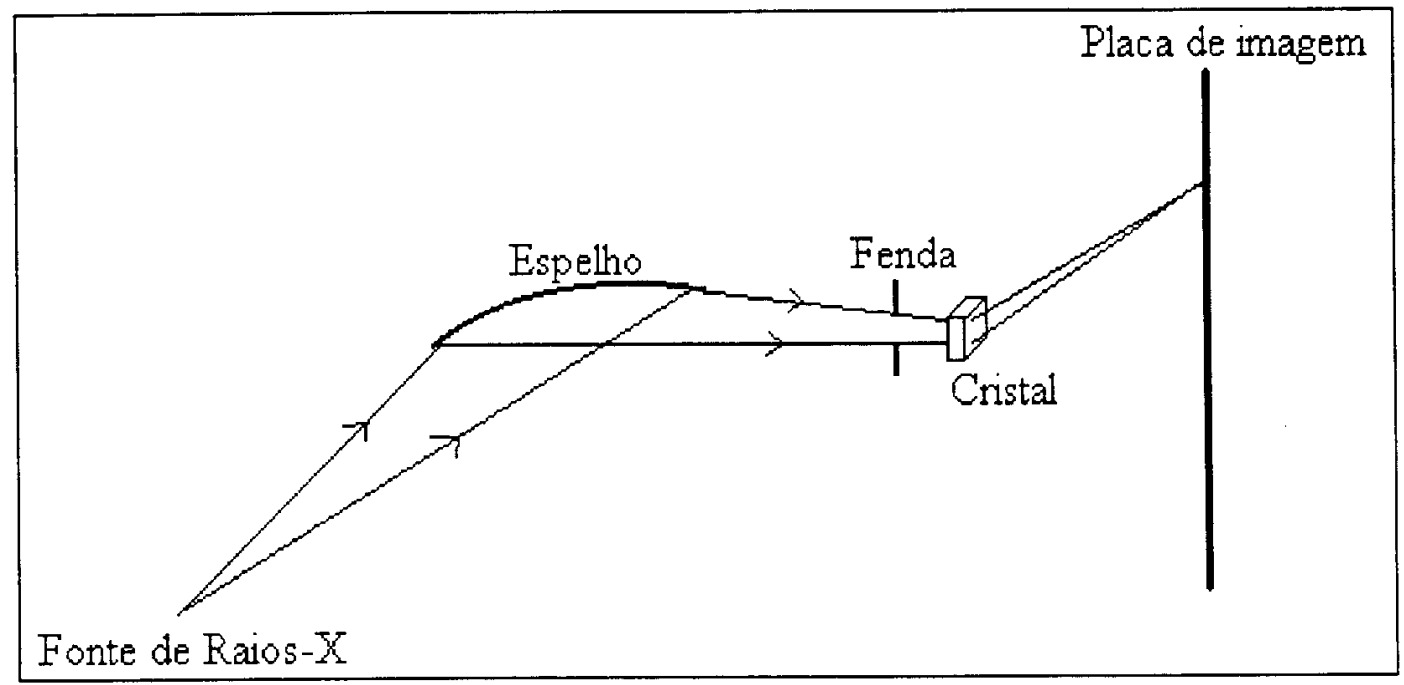

Figura 5.9. Diagrama esquemático do espelho focalizador de raios $X$. Os ângulos na figura estão exagerados para efeito de ilustração.

\subsubsection{Colimador (Giacovazzo, 1992a).}

A função dos colimadores é definir um feixe de raios $\mathrm{X}$ estreito que seja o mais paralelo possivel. 
Um colimador de orificio está mostrado na figura 5.10. Ele consiste de um cilindro com duas aberturas $\left(S_{1}\right.$ e $\left.S_{2}\right)$ que limitam o feixe e uma terceira $\left(S_{3}\right)$, que não afeta o tamanho do feixe definido pelas outras duas, mas elimina a radiação espalhada pela abertura mais distante da fonte de raios $X$ (abertura $S_{2}$ ). Colimadores cilíndricos de orificio são usados tipicamente com fontes convencionais de raios $\mathrm{X}$ (tubos selados ou ânodo rotatório) (seção 5.6.1), para definir um feixe que foi monocromatizado por uma cristal monocromador (seção 5.6.2) ou por um filtro. Tais colimadores nunca produzem um feixe idealmente paralelo, mas além do feixe paralelo produzem também feixes convergente e divergente, como mostrado na figura 5.10. Seja 1 a distância entre as aberturas $S_{1}$ e $S_{2}$ e d o diâmetro do colimador, o ângulo máximo de divergência do feixe, $\gamma$, é dado por:

$$
\tan \frac{\gamma}{2}=\frac{d / 2}{l / 2}=\frac{d}{l}
$$

e visto que o ângulo $\gamma$ é muito pequeno podemos usar a seguinte aproximação:

$$
\tan \frac{\gamma}{2} \cong \operatorname{sen} \frac{\gamma}{2} \cong \frac{\gamma}{2}=\frac{d}{l} \therefore \gamma=\frac{2 d}{l}
$$

onde o ângulo $\gamma$ é calculado em radianos.

Como exemplo, consideremos um colimador típico com as dimensões $d=0,5 \mathrm{~mm}$ e l $=50 \mathrm{~mm}$, usando a equação 5.1 , temos que o ângulo de divergência é:

$$
\gamma=\frac{2 \times 0,5}{50}=2 \times 10^{-2} \text { radianos } \text {. }
$$

Várias condições podem ser ajustadas para se otimizar a colimação do feixe de raios $\mathrm{X}$. As variáveis que podem ser ajustadas são os tamanhos do cristal e do foco do feixe de raios X, a distância cristal-foco e a distância cristal-detetor (Arndt \& Wonacott, 1977) 


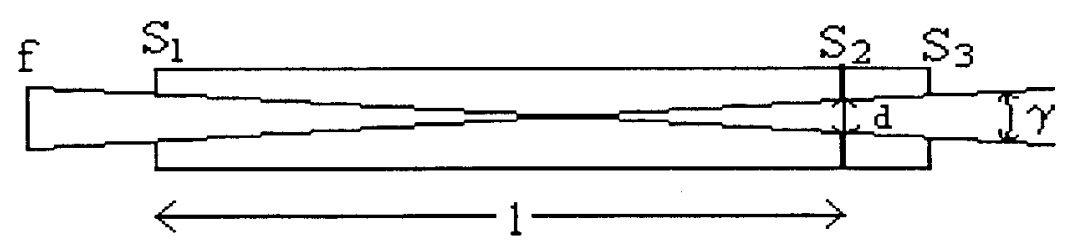

Figura 5.10. Colimador de orificio mostrando o ângulo de maior divergência $(\gamma)$.

\subsubsection{Câmara de oscilação (Giacovazzo, 1992).}

No método de oscilação o cristal oscila por pequenos ângulos (para frente e para trás) em torno de um eixo perpendicular ao feixe de raios $\mathrm{X}$, e as intensidade difratadas são registradas em um filme plano ou uma placa de imagem, como no caso do R-AXIS IIC. Usa-se pequenos ângulos de oscilação para evitar superposição de reflexões na placa de imagem. Uma unidade assimétrica do espaço recíproco do cristal é coletada usando-se sucessivas exposições. Assim, se for necessário coletar uma faixa completa de $90^{\circ}$, podese coletar 45 imagens de $2^{\circ}$ de oscilação cada, desde que não haja superposição usando-se oscilações de $2^{\circ}$.

$\mathrm{Na}$ análise da geometria da câmara de oscilação é mais conveniente deixar-se a rede reciproca fixa e permitir que a esfera de Ewald se mova (Giocovazzo, 1992 p.261). Quando o cristal é girado de um pequeno ângulo $\Delta \phi$, os dois círculos que resultam da intersecção da esfera de Ewald ao início e ao fim da rotação (figura 5.11a) com cada plano da rede reciproca, definem duas luas crescentes que contém todos os pontos da rede recíproca que produzirão pontos de difração sobre a placa de imagem. Desta forma, uma imagem de oscilação, contém reflexões vindas de todas as camadas recíprocas que interceptam a esfera de Ewald, como mostrado na figura 5.11b. As reflexões contidas em cada um dos pares de luas crescentes são provenientes do mesmo plano do retículo recíproco e por esta razão possuem um índice em comum. 
a)

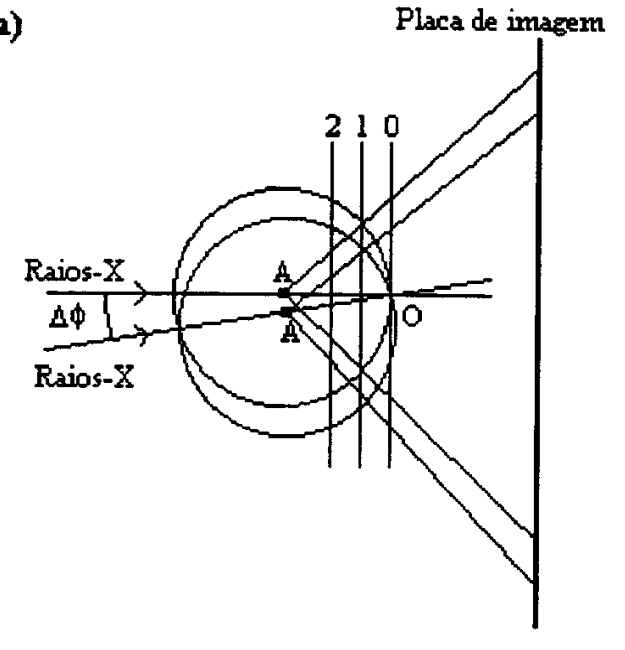

b)

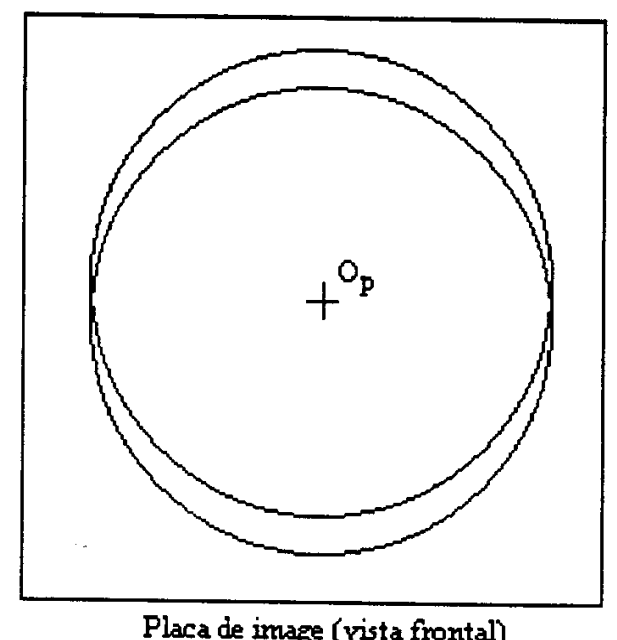

Figura 5.11. Movimento de rotação. a) No movimento de rotação temos que os planos do retículo reciproco estão fixos enquanto a esfera de Ewald gira em torno do ponto $\mathrm{O}$, b) A projeção da intesecção da esfera de Ewald com um plano da rede recíproca sobre a placa de imagem. (Giacovazzo, 1992. p.261, fig. 4.27)

Visto que os "pontos" do espaço recíproco possuem volume, chamaremos tais pontos de nódulos. Então, temos que, uma reflexão não estará totalmente registrada a menos que todo o volume do nódulo do espaço recíproco tenha passado pela esfera de Ewald. Qualquer reflexão, cujo o nódulo do espaço recíproco não tenha passado completamente pela esfera de Ewald, é chamada de reflexão parcialmente registrada, ou simplesmente, reflexão parcial. Considerando-se que os ângulos de oscilação empregados para coleta de dados de cristais de macromoléculas biológicas são bem pequenos, temos que, um número substancial de reflexões em uma dada imagem serão reflexões parciais. Estas reflexões têm de ser adequadamente identificadas e tratadas durante o processamento de imagens. As reflexões parciais registradas em imagens diferentes podem ser somadas produzindo um valor confiável para a intensidade da reflexão total.

Durante uma coleta de dados a câmara de oscilação tem de limitar o ângulo varrido em cada imagem de forma a evitar a superposição de reflexões diferentes na mesma imagem, ou seja, evitar que nódulos de diferentes planos do espaço recíproco produzam reflexões que se superponham numa mesma imagem. Quando tal superposição 
ocorre fica dificil distinguir que parte da intensidade medida é refente a cada reflexão. A expressão para o ângulo de oscilação máximo $\left(\Delta \phi_{\max }\right)$ é dado por:

$$
\Delta \phi_{\max }=\arctan \frac{\left|\mathbf{d}_{\mathbf{m i n}}\right|}{\mathbf{a}}-\Delta
$$

onde $\mathrm{d}_{\min }$ é a resolução máxima do conjunto de dados coletados, a é um eixo do cristal perpendicular ao eixo de rotação e $\Delta$ é a largura do ponto de difração. Como exemplo, consideremos um cristal ortorrômbico com os seguintes parâmetros de cela unitária, $\mathrm{a}=$ $73 \AA, \mathrm{b}=71 \AA, \mathrm{c}=54 \AA$ e com os pontos de difração com largura de $0,5^{\circ}$ e deseja-se coletar dados a uma resolução de $2,5 \AA$. O cristal está montado de tal forma que o eixo mais longo, a, está ao longo do eixo de rotação. Quando o sistema oscila com o eixo c no plano da placa de imagem, o ângulo de oscilação máximo é limitado pelo eixo b, de maneira que $\Delta \phi_{\max }=\arctan (2,5 / 71)-0,5^{\circ}=1,52^{\circ}$, e quando o eixo c é o limitante, o ângulo de oscilação máximo é $\Delta \phi_{\max }=2,15^{\circ}$. Em resumo podemos estabeler que o ângulo de oscilação máximo depende de três fatores:

i) Tamanho da cela unitária. Para celas unitárias maiores precisamos de ângulos de oscilaçoes menores. Somente os eixos do cristal que são perpendiculares ao eixo de rotação que são limitantes do ângulo máximo. O eixo ao qual o cristal é rotacionado não é limitante.

ii) O tamanho do nódulo de difração ou mosaicidade. A largura do nódulo de difração na direção de rotação é tipicamente de $0,1^{\circ}$ a $0,5^{\circ}$. A mosaicidade, que é expressa aproximadamente por esta largura, é a medida da ordem interna do cristal. Se um cristal possue baixa mosaicidade, o cristal é altamente ordenado e os pontos de difração serão mais estreitos. Cristais de alta mosaicidade terão pontos de difração mais largos devido à baixa ordem cristalina.

iii) Resolução. Quanto maior a resolução desejada menor é o ângulo máximo de oscilação permitido. O máximo de superposição dos pontos de reflexão ocorrerá na área da imagem perpendicular ao eixo de rotação e no ângulo máximo de difração.

Para a coleta de dados usando o R-AXIS IIC o operador pode definir o ângulo de oscilação, quando este já tiver as informaçoes sobre os parâmetros da cela unitária, orientação do cristal e grupo espacial. 


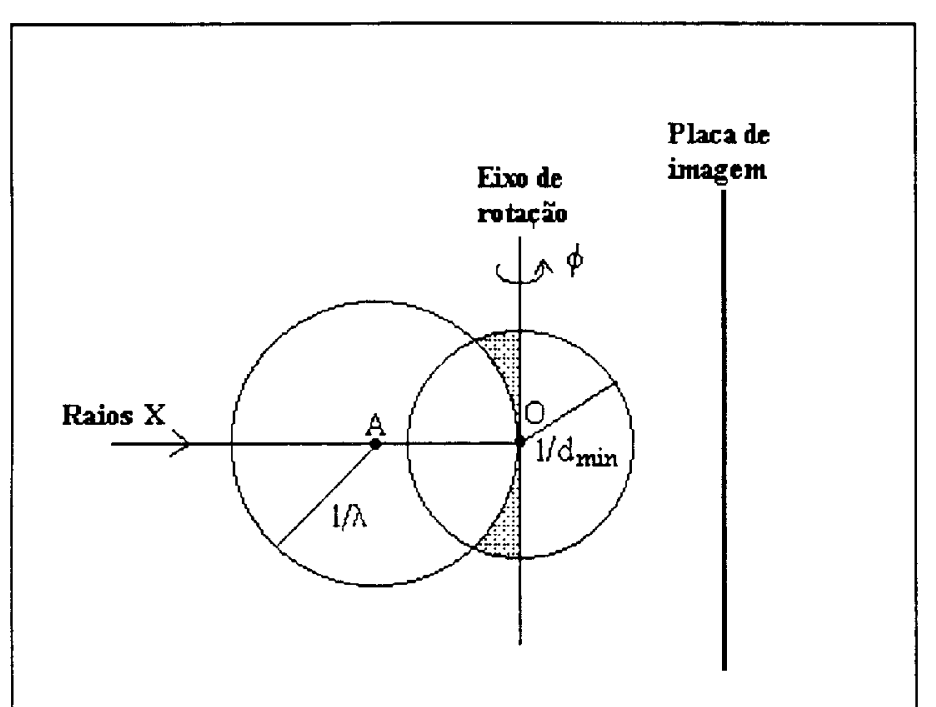

Figura 5.12. Geometria da câmara de oscilação. $\mathrm{Na}$ figura temos a esfera de Ewald (esfera maior) projetada sobre o plano definido pelo feixe raios $\mathrm{X}$ e o eixo de rotação. A região pontilhada representa o volume do espaço recíproco que é inacessivel no movimento do rotação.
$\mathrm{Na}$ figura 5.12 temos a esfera Ewald projetada sobre o plano determinado pelo feixe raios $\mathrm{X}$ e o eixo de rotação do cristal. A esfera limitante de raio menor representa a máxima resolução do conjunto de dados que será coletado no experimento de oscilação. A rotação máxima do cristal, ou seja, a soma das oscilações individuais, representada por uma rotação de $360^{\circ}$ da esfera de Ewald em torno do eixo de rotação, cobrirá o volume do espaço recíproco limitado pelo toróide gerado pela rotação da esfera de Ewald e deixará de fora o volume pontilhado da figura 5.12, esta é a região cega inacessível à geometria da câmara de oscilação. Esta região cega cresce com a resolução do dado a ser coletado. A figura 5.13 mostra um gráfico da porcentagem do espaço recíproco que não pode ser medido num experimento de oscilação como função da resolução (Arndt \& Wonacott, 1977).

Temos na figura 5.14 o volume total do espaço recíproco varrido conforme o cristal é girado de um ângulo total de $30^{\circ}, 90^{\circ}$ e $180^{\circ}$. A partir da figura 5.14 é evidente que mesmo para eixos de rotação sem simetria nunca é necessário rotacionar o cristal muito mais que $180^{\circ}$ para se cobrir todo o espaço recíproco, com exceção da região cega, não mostrada na figura 5.14. O volume que não foi coberto pela rotação de $180^{\circ}$ está em preto na figura $5.14 \mathrm{c}$ e seu tamanho depende da resolução desejada conforme pode ser visto na mesma figura. A partir da figura 5.14, está também claro, que a fim de minimizar o ângulo total de rotação, é desejável girar o cristal em torno do seu eixo cristalográfico de mais alta simetria. Levando-se em consideração as simetrias dos grupos espacias e a lei de Friedel (seção 4.9) temos que somente uma parte do espaço recíproco precisa ser 
varrida para se obter todos os dados possíveis para um dado cristal (estes são chamados dados únicos). Considerando o caso de cristais pertencentes ao sistema cristalino triclínico só é necessário medir metade dos dados, ou seja, uma rotação total de $180^{\circ}$ em torno de um eixo conveniente. Se temos um cristal hexagonal deveremos girar em torno do eixo c, desta forma, uma rotação total de $30^{\circ}$ será suficiente para cobrir uma unidade assimétrica do espaço recíproco no qual o único volume faltando será a região cega. Para um cristal ortorrômbico podemos rotacionar $90^{\circ}$ em torno que qualquer eixo conveniente, levandose em consideração a limitação da extenção de cada oscilação por imagem. Para outros sistemas cristalinos deve-se levar em conta que elementos de simetria estão presentes ( International tables for crystallography, Vol. A., 1983). Para se coletar todos os dados, desconsiderando-se a região cega, se faz necessário ainda uma rotação extra de $2 \theta$, onde $2 \theta$ é o ângulo de espalhamento para a mais alta resolução a ser coletada. Tal termo adicional se faz necessário devido à curvatura da esfera de Ewald (McRee, 1993).

Ainda considerando-se o eixo de rotação, temos que a simetria do cristal não é o único fator a se considerar na sua escolha. Um outro fator, igualmente importante, é o

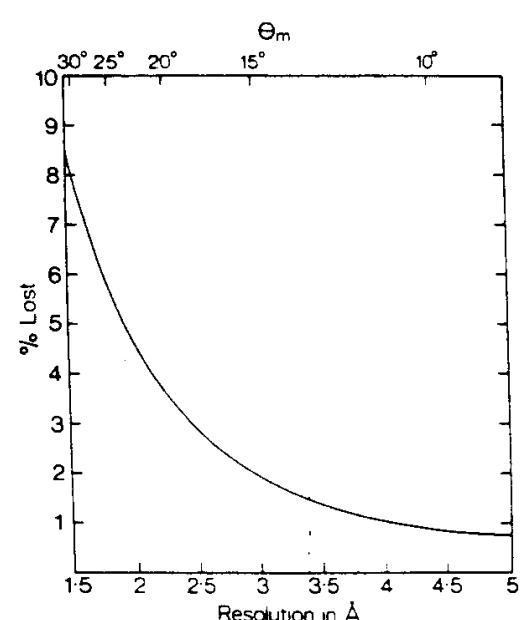

Figura 5.13. Porcentagem do espaço recíproco que não pode ser medido por rotação em torno de um único eixo, em função da resolução (Arndt \& Wonacott, 1977, pp81). tamanho dos parâmetros da cela unitária. Nós vimos que o intervalo máximo de oscilação por imagem (equação 5.2) é dependente da cela unitária. Assim seria ideal se girar o cristal em torno de seu maior parâmetro de cela, de forma que, este não seja o fator limitante na escolha da oscilação máxima por imagem. Um outro fator prático a ser considerado, que pode limitar a liberdade de escolha de um eixo de rotação, é a morfologia do cristal. Cristais que crescem em forma de uma placa muito fina, com o seu eixo de mais alta simetria perpendicular à placa, não podem ser facilmente montados, usando-se este como eixo de rotação. 


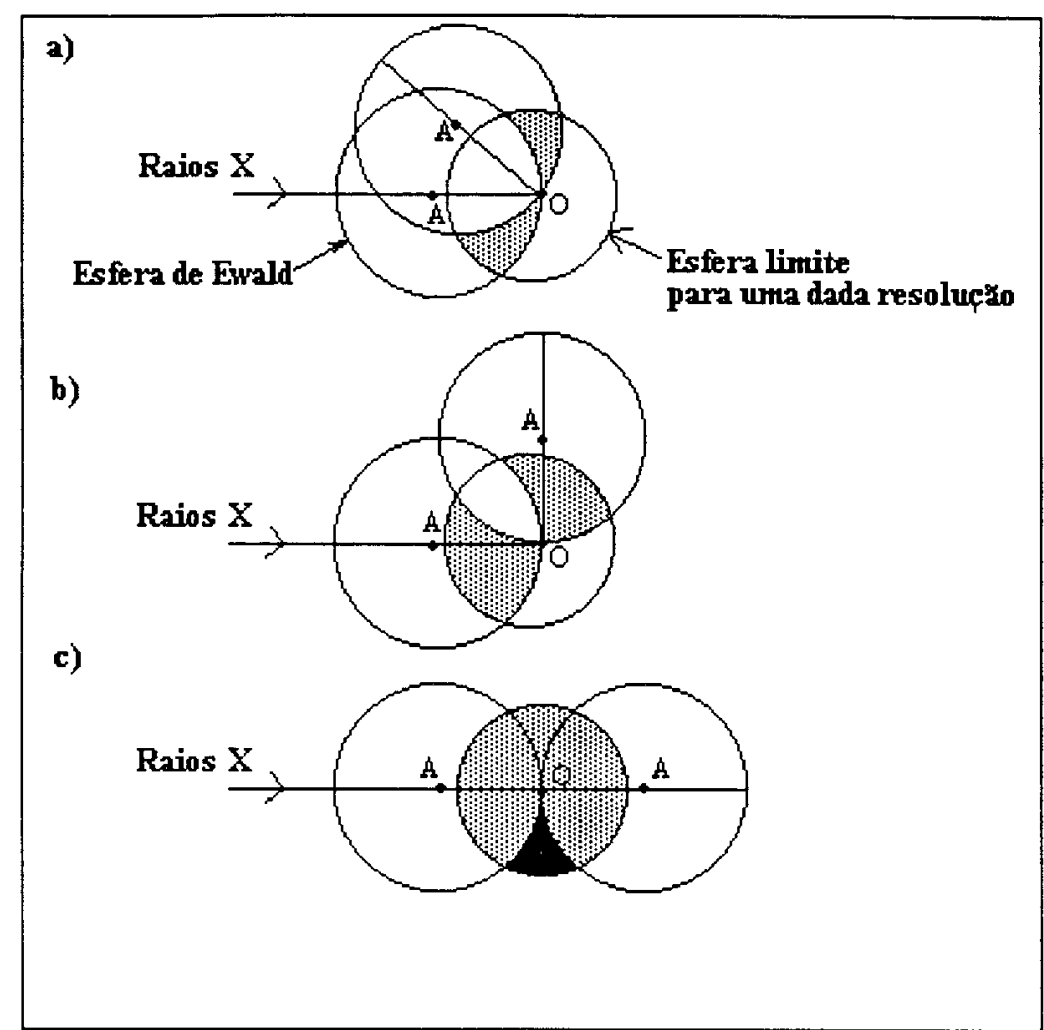

Figura 5.14. Espaço recíproco. Volume do espaço recíproco explorado por uma rotação de ângulo total de $30^{\circ}$ (a), $90^{\circ}$ (b) e $180^{\circ}$ (c ). Em cada caso a esfera limite corresponde a uma resolução escolhida que define o volume do espaço recíproco de interesse. $\mathrm{O}$ volume do espaço recíproco coberto em cada rotação completa é indicado em pontilhado.

\subsubsection{Placa de imagem (Drenth, 1994).}

As placas de imagem são feitas depositando-se uma fina camada de um material semicondutor, como o haleto de bário dopado com európio $\left(\mathrm{BaFBr}_{\mathrm{Eu}}{ }^{2+}\right.$ ), sobre uma base plana. Os fótons de raios $\mathrm{X}$, quando incidem sobre esta placa, excitam os elétrons no material semicondutor para um nível de energia mais alto, ou seja, alguns dos íons $\mathrm{Eu}^{2+}$ são transformados $\mathrm{em} \mathrm{Eu}^{3+}$, e os elétrons que são liberados são aprisionados nas vacâncias de $\mathrm{Br}^{\circ}$ introduzidas no cristal, formando os chamados centros $\mathrm{F}$. Parte desta energia é emitida, entretanto uma quantidade apreciável de energia é retida no material por elétrons aprisionados nos centros de cor. O centro $\mathrm{F}$ decai quando iluminado com um laser de $\mathrm{He}-$ $\mathrm{Ne}(633 \mathrm{~nm})$, produzindo luminescência em 390nm (azul) que é amplificada com uma fotomultiplicadora. A luz emitida é proporcional ao número de fótons de raios $\mathrm{X}$ ao qual 
aquela parte da placa foi exposta. Antes de se coletar uma nova imagem a placa é exposta a uma forte luz branca que a apaga. As placas de imagem usadas no sistema R-AXIS IIC (figura 5.7) possuem dimensões de $200 \mathrm{~mm}$ x $200 \mathrm{~mm}$ divididas em 1900 por 1900 pixels de dimensões de $105 \mu \mathrm{m}$ x $105 \mu \mathrm{m}$ cada um. Um outro componente do equipamento de coleta de dados que vale a pena ser mencionado é o aparador do feixe direto (beam stop), que evita que o feixe direto de raios $\mathrm{X}$ incida sobre a placa de imagem. Um sistema $\mathrm{R}$ AXIS IIC completo está mostrado na figura 5.15 idêntico ao que existe no Laboratório de Cristalografia de Proteínas do IFSC-USP.

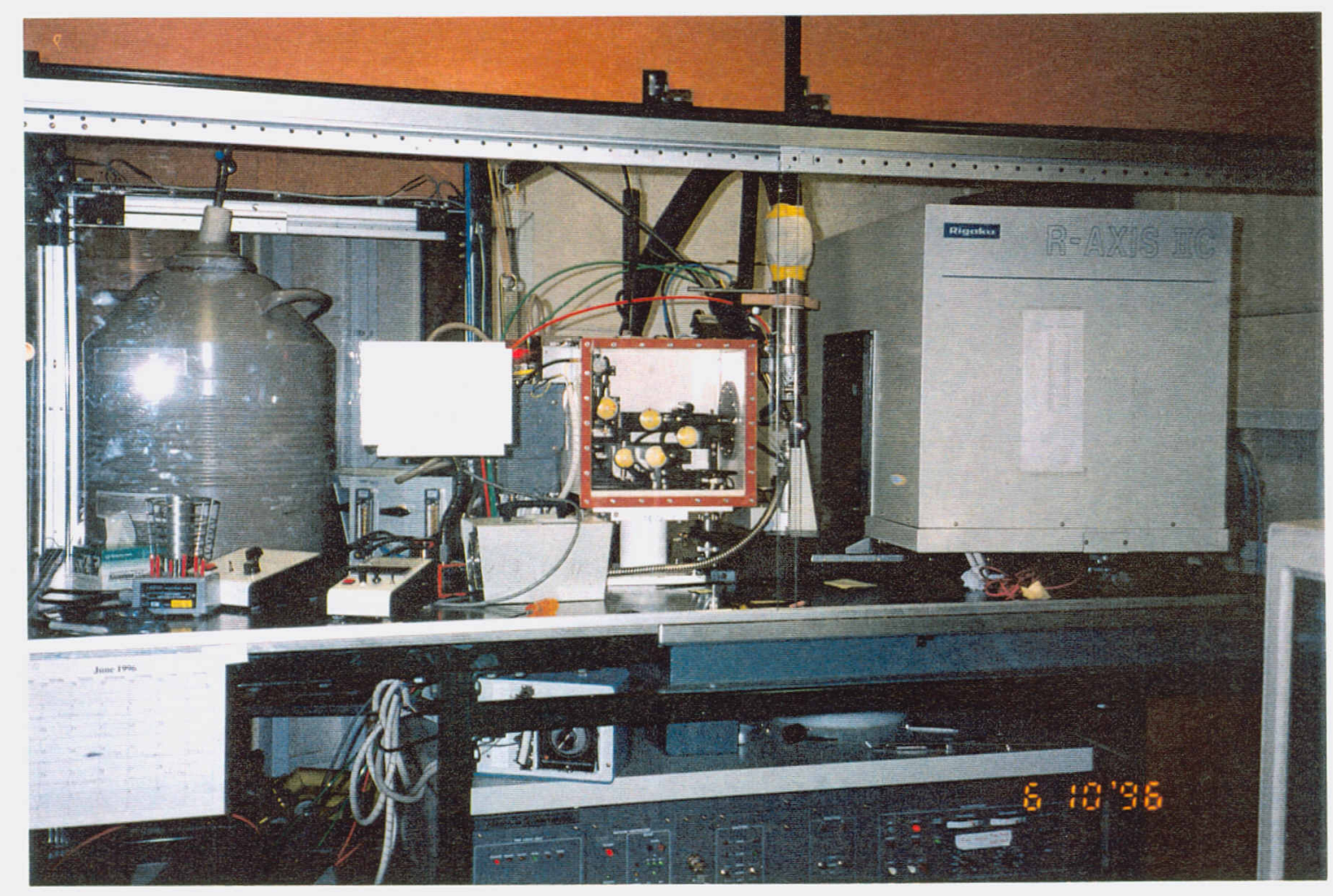

Figura 5.15. Sistema R-AXIS IIC da University of California at Berkeley, USA (1996).

\subsection{Coleta e processamento de dados usando o R-AXIS IC (Sato et al., 1992).}

Dois pacotes de programas são fornecidos junto com o equipamento R-AXIS IIC: um controla o difratômetro de placa de imagem mecanicamente, tira as imagens de raios X com o cristal imóvel (still) ou de oscilação e transfere as imagens para a estação de 
trabalho. O outro pacote de programas processa as imagens para se obter um conjunto de dados de difração. Ambos pacotes de programas são controlados via menus que são de fácil uso. A tabela 5.1.a lista os programas do pacote de controle e suas funções. $\mathrm{O}$ programa MEASUREMENT é o mais frequentemente usado durante a rotina de coleta de dados. Informações sobre o cristal, o gerador de raios $\mathrm{X}$ e as condições de coleta são inseridas pelo operador e as imagens still ou de oscilação são tiradas sob estas condições. O programa $M A N U A L$ é usado principalmente para se estabelecer as condições da máquina comandando-se cada função independentemente. Os outros programas são subsidiários. A tabela 5.1.b lista os programas de processamento de dados. Após as condições de trabalho serem estabelecidas pelo programa SETUP, o programa STILL analisa as imagens still para determinar a orientação do cristal, o programa OSCILL calcula as intensidades integradas das reflexões das imagens de oscilação e finalmente o programa SCALE determina os fatores de escala das imagens e faz a média das reflexões relacionadas por simetria para gerar um conjunto de reflexões independentes.

Tabela 5.1. Programas usados para o controle e processamento de dados (Sato et al., 1992).

\begin{tabular}{ll}
\hline (a) Programas para controle do difratômetro. & \\
INITIALIZE & Inicialização do sistema de hardware. \\
ALIGNMENT & Alinhamento do cristal. \\
MEASUREMENT & Coleta de uma série de imagens still ou de oscilação \\
MANUAL & Operação manual de cada parte do hardware. \\
DATAFILE & Coloca a informação da coleta de dados no cabeçalho do \\
& arquivo de imagem. \\
(b) Programas para processamento das imagens & \\
SETUP & Fornece ao programa as informações necessárias para sua \\
& operação. \\
STILL & Determina a matriz de orientação do cristal. \\
OSCILL & Indexa e calcula as intensidades das reflexões. \\
SCALE & Escalona as intensidades. \\
PLOT & Mostra os pontos de difração previstos e observados \\
& numa janela gráfica.
\end{tabular}


Para se estabelecer uma orientação do cristal usa-se o procedimento de autoindexação de Higashi ( Higashi et al., 1990), a partir do qual uma matriz de orientação é calculada para um cristal em posição qualquer, mesmo sem conhecimento prévio dos parâmetros da cela unitária. O método de ajuste do perfil de Rossmann é usado para se estimar as intensidade integradas para todas as reflexões. O método de Fox \& Holmes (1966) é usado para refinar os fatores de escala das imagens. E uma procedimento de pósrefinamento é disponível no programa SCALE ( Winkler, Schutt \& Harrison, 1979; Rossmann et al., 1979)

Os principais passos para a coleta de dados e processamento das imagens coletadas usando o equipamento da R-AXIS IIC da Rigaku Co., são apresentados a seguir.

\subsubsection{Alinhamento do cristal.}

Uma vez tenhamos o cristal montado numa cabeça goniométrica faz-se necessário a alinhamento deste cristal com o feixe de raios X. Tal alinhamento ótico é feita com o equipamento de raios $\mathrm{X}$ desligado, ou seja, sem que haja incidência de raios $\mathrm{X}$ tanto sobre o cristal quanto sobre o operador. O equipamento dispõe de um sistema ótico composto de uma luneta com "+", calibrada de tal forma que quando o cristal estiver sobre o centro deste " + ' estará alinhado com o feixe de raios $X$. Por alinhado entende-se que durante uma rotação de $360^{\circ}$ do eixo de rotação, o cristal esteja sempre sob o feixe de raios $\mathrm{X}$. O suporte da cabeça goniométrica permite translação vertical o que possibilita o posicionamento do cristal. Após este posicionamento passa-se ao ajuste do eixo de rotação. Considerando-se o cristal num ângulo inicial $\phi=0$, usam-se os ajustes de translação horizontal da própria cabeça goniométrica para se posicionar o cristal sobre o centro do "+" da luneta, feito isto, gira-se o cristal de $180^{\circ}$, e o colocamos novamente sobre o centro do " + ". Move-se agora para $\phi=90^{\circ}$, centra-se novamente o cristal, gira-se para $\phi=270^{\circ}$ e repete-se o processo. O cristal estará razoavelmente alinhado, quando girando-se $360^{\circ}$ o cristal fica sobre o centro do “+” durante toda a rotação. Caso contrário, procede-se ao ajuste fino repetindo o procedimento inicial. Caso o cristal tenha que ser mantido em condições criogênicas recomenda-se que o alinhamento se faça antes 
de se inserir o cristal no laço (figura 5.3), isto se faz, seguindo-se o mesmo processo de alinhamento descrito anteriormente, contudo, como não se tem o cristal ainda no laço, usa-se o centro do laço como referência para o alinhamento, uma vez que alinhamento tenha sido feito, pode-se proceder a colocação do cristal no laço e então confirmar-se o alinhamento. Normalmente só um pequeno ajuste fino se fará necessário posteriormente.

\subsubsection{Coleta e processamento das imagens Still (Arndt \& Wonacott, 1977, Fontes,} 1995).

Para a coleta das primeiras imagens de raios $\mathrm{X}$ é necessário antes que se estabeleçam a voltagem e a corrente que serão aplicadas ao ânodo rotatório. Na coleta de dados dos cristais de CDK2 em complexo com inibidores usou-se $50 \mathrm{kV}$ e $100 \mathrm{~mA}$. Outro parâmetro a ser ajustado é a distância cristal-placa de imagem (D). Esta distância será um dos determinantes da máxima resolução possível do conjunto de dados, quando mais próxima a placa de imagem do cristal maior é a resolução máxima possível. Contudo, se o cristal não difrata além de $3 \AA$, de nada adianta colocar a placa de imagem a uma distância de $55 \mathrm{~mm}$ para coleta de dados de $1,51 \AA$, seus dados terão resolução de $3 \AA$. Assim, quando nada se sabe sobre o cristal a ser coletado deve-se coletar uma única imagem still e então avaliar o poder de difração do cristal. Caso existam muitos pontos fortes de difração próximos à borda da imagem deve-se aproximar a placa de imagem ao cristal, caso contrário deve-se afastar. Um cuidado que se deve tomar ao estimar a resolução a partir de uma imagem still é a heterogenidade da morfologia do cristal. Cristais que crescem em forma de placa tendem a difratar mais em uma dada direção do que na outra, ou seja, caso se estime o poder de difração numa posição favorável pode-se ter uma superestimação do poder de difração do cristal como um todo.

Como todos os pontos de difração na placa de imagem serão localizados em relação às coordenadas do centro da placa de imagem é necessário a determinação destas coordenadas com boa precisão. Para se determinar o centro da placa de imagem se faz necessário um pequeno experimento antes da coleta das imagens still do cristal. Sem o cristal montado expõe-se a placa de imagem com o feixe direto, ou seja, sem o aparador de feixe ( beam stop ) por $0,1 \mathrm{~s}$. Tal exposição irá gerar um ponto preto sobre a placa de 
imagem e as coordenadas deste ponto é que serão consideradas como o centro da placa. Como este centro costuma variar um pouco conforme se varia a distância D é aconselhável determinar-se o centro para duas ou mais distâncias $\mathrm{D}$, e usar as coordenadas do centro que mais se aproximam das condições experimentais da coleta. Por exemplo, mediu-se as coordenadas do centro da imagem para duas distâncias, $D=100 \mathrm{~mm}$ e $\mathrm{D}=$ $200 \mathrm{~mm}$, e quando foi coletar-se dados usou-se uma distância D=120mm. Então deve-se usar as coordenadas do centro obtidas para a distância $\mathrm{D}=100 \mathrm{~mm}$, visto que, esta é a mais próxima de $120 \mathrm{~mm}$. Uma vez determinado as coordenadas do centro da placa de imagem pode-se usar este valor até que o filamento do ânodo rotatório se queime, quando novo valor para as coordenadas do centro deverá ser medido, visto que, toda vez que se substitui o filamento do ânodo rotatório pode-se variar o centro da placa de imagem.

As imagens still são imagens coletadas com o eixo de rotação (ângulo $\phi$ ) fixo, ou seja, sem oscilações durante a exposição de raios X. As informações obtidas com estas imagens permitem o cálculo da matriz de orientação do cristal em relação ao sistema de coordenadas do laboratório e os parâmetros da cela unitária, tal processo é chamado de auto-indexação. O algorítmo usado no programa STILL permite a indexação das imagens still, sem qualquer informação sobre os parâmetros da cela unitária do cristal, mas o algorítmo é altamente simplificado caso sejam conhecidos os parâmetros da cela unitária do cristal (Higashi, 1990). O processo de auto-indexação é equivalente a se achar três vetores de base a partir de um conjunto de vetores de espalhamento (S) observados experimentalmente. No algorítmo de processamento de imagens stills o primeiro passo é a localização dos pontos de difração em relação ao centro da placa de imagem, atribuindoas as coordenadas $(\mathrm{Y}, \mathrm{Z})$; estas juntamente a distância $\mathrm{D}$ podem ser expressas pelo vetor:

$$
\mathrm{X}=(\mathrm{D}, \mathrm{Y}, \mathrm{Z})
$$

Após isto, transforma-se o vetor $\mathbf{X}$ para o espaço recíproco, sendo chamado agora de $\mathbf{X}$ ' este pode ser expresso usando-se os indices de Miller (hkl) usando-se a seguinte equação matricial:

$$
\mathbf{X}^{\prime}=\mathbf{A} \mathbf{H}
$$


onde o ângulo de oscilação foi tomado como $\phi=0^{\circ}$, A representa a matriz de orientação cristalina que contém os três vetores de base a ser obtidos por este algoritmo e $\mathbf{H}$ um vetor do espaço recíproco de índices (hkl). Calcula-se a seguir, vetores diferença de $\mathbf{X}$ ' para uma resolução dada, e estes vetores $\left\{\mathbf{v}_{1}, \mathbf{v}_{2}, \ldots, \mathbf{v}_{\mathbf{n}}\right\}$ são ordenados segundo seus comprimentos. No passo seguinte os vetores são selecionados como vetores de base, usando-se os critérios:

$$
\begin{aligned}
& \text { ângulo }\left(\mathbf{v}_{1}, \mathbf{v}_{2}\right)>\mathrm{C}_{1} \\
& 90^{\circ} \text { - ângulo }\left(\mathbf{v}_{1} \times \mathbf{v}_{2}, \mathbf{v}_{\mathbf{3}}\right)>\mathrm{C}_{2}
\end{aligned}
$$

onde os valores típicos de $C_{1}$ e $C_{2}$ são $C_{1}=30^{\circ}$ e $C_{2}=\theta_{\max }$ (da coleta de dados). A partir destes vetores tem-se a matriz $\mathbf{A}$, que na realidade é uma escolha arbitrária ( pois, há outros valores possíveis de base que também são soluções) e na maioria das vezes é necessário uma redução para a cela apropriada. A matriz A pode ser refinada por mínimos quadrados, baseado no fato que os índices de Miller devem ser números inteiros. Tem-se, desta maneira, a matriz $\mathbf{A}$ e os parâmetros de rede a partir dos quais podem ser calculados os índices de Miller de cada reflexão usando-se a equação 5.4 .

No caso dos parâmetros de rede já conhecidos, deve-se orientar o cristal pelos três ângulos a partir dos eixos ortogonais $\phi_{x}, \phi_{y}, \phi_{z}$ (Arndt \& Wonacott, 1977 p.78). Da mesma maneira que no caso anterior, deve-se calcular a matriz $\mathbf{A}$ (definida acima), que pode ser obtida pelas contribuições dos parâmetros de rede e das operações de rotação que são dadas pela equação:

$$
\mathbf{A}=\mathbf{R} \mathbf{A}_{0}
$$

onde $\mathbf{R}$ é uma matriz de rotação que pode ser dada em termos das rotações em função de cada ângulo $\phi_{\mathrm{x}}, \phi_{\mathrm{y}}, \phi_{\mathrm{z}}$ (Arndt \& Wonacott, 1977 p.78), pela equação:

$$
\mathbf{R}=\mathbf{R}_{\mathbf{x}}\left(\phi_{\mathrm{x}}\right) \mathbf{R}_{\mathbf{y}}\left(\phi_{\mathrm{y}}\right) \mathbf{R}_{\mathrm{z}}\left(\phi_{\mathrm{z}}\right)
$$

e $\mathbf{A}_{\mathbf{0}}$ é dado pela matriz:

$$
\mathbf{A}_{\mathbf{0}}=\lambda \cdot\left(\begin{array}{ccc}
\mathrm{a}^{*} & \mathrm{~b}^{*} \cos \gamma^{*} & \mathrm{c}^{*} \cos \beta^{*} \\
0 & \mathrm{~b}^{*} \operatorname{sen} \gamma & -\mathrm{c}^{*} \operatorname{sen} \beta^{*} \cos \alpha \\
0 & 0 & 1 / \mathrm{c}
\end{array}\right)
$$


A matriz $\mathbf{A}_{\mathbf{o}}$ pode ser calculada pelos parâmetros de rede já conhecidos, e para calcular a matriz $\mathbf{A}$ o melhor procedimento é conhecido comparação de vetores (vectormatching procedure ). Este método consiste em indexar alguns vetores (entre 3 e 5) da lista de vetores diferença por comparação com vetores que são gerados dos parâmetros de rede conhecidos ( por meio da matriz $\mathbf{A}_{\mathbf{0}}$ ). Destes vetores e dos seu índices obtidos, a matriz $\mathbf{A}$ pode ser calculada a partir de uma equação equivalente à equação 5.4 ( onde esta é ponderada, baseado no fato que os índices de Miller tem que ser números inteiros). Desta maneira, obtém-se estas duas matrizes e usando-se as equações 5.6 e 5.7 pode-se calcular a orientação do cristal ( ângulos $\phi_{x}, \phi_{y}, \phi_{z}$ ) (Kabsch, 1988).

O programa, após o processo de indexação e determinação dos parâmetros de rede do cristal, faz um refinamento destes parâmetros incluindo os parâmetros da câmara (tais como, distância cristal-placa de imagem, coordenadas do centro da placa $\left(\mathrm{X}_{\mathrm{cen}}, \mathrm{Y}_{\mathrm{cen}}\right)$, ângulo ômega (deslocamento angular do eixo de rotação do cristal em relação ao eixo vertical de leitura da placa de imagem, etc).

Para o processo de auto-indexação é recomendado o uso de no mínimo duas imagens still coletadas a diferentes ângulos $\phi$, por exemplo $\phi=0^{\circ}$ e $\phi=90^{\circ}$. Estas imagens devem ter por volta de no mínimo 100 pontos de difração com boa intensidade, para que se possa obter uma boa estatística no processo de auto-indexação.

\subsubsection{Coleta e integração das imagens de oscilação (Higashi et al., 1990, Arndt \&} Wonacott, 1977, Fontes, 1995, Giacovazzo, 1992).

Com a orientação e os parâmetros de cela determinados deve-se prossseguir com a coleta de dados. Para isto deve-se definir o quanto cada imagem de oscilação irá oscilar $(\Delta \phi)$, o número de imagens a ser coletado e o tempo de exposição de cada imagem. Os aspectos a serem considerados para a seleção do $\Delta \phi$ já foram discutidos na seção $5.6 .5,0$ número de imagens deve ser tal que quando multiplicado pelo $(\Delta \phi)$ cubra uma região do espaço recíproco suficiente para conter uma unidade assimétrica (seção 5.6.5). Já o tempo de exposição deve ser determinado empiricamente através da observação de diversos fatores tais como, danos por radiação, resolução desejada, radiação de fundo, etc. Através do uso do programa OSCILL é possivel fazer-se uma simulação das condições da coleta 
de dados. O operador tem diponível para isto a opção simulation. Os parâmetros de entrada são $\Delta \phi$, o ângulo de início de coleta, o ângulo final de coleta e a resolução. $O$ programa usa as informações obtidas da autoindexação ( orientação do cristal e cela unitária) para fazer a simulação. A saída da simulação fornece o quanto de superposição e a porcentagem do conjunto de dados coletados acumulativamente em cada imagem, desta forma, o usuário pode ver ser a escolha das condições de coleta de dados feita por ele não estão gerando dados com muita superposição de pontos de difração e se o número de imagens é suficiente para uma boa completeza dos dados. A completeza é o número de reflexões únicas medidas dividida pelo número de reflexões únicas possíveis em uma dada resolução. Assim um conjunto de dados $92 \%$ completo à resolução de $2,33 \AA$ indica que $8 \%$ das reflexões únicas possíveis estão faltando. A quantidade de completeza necessária é dependente de diversos fatores, mas como regra geral temos que dados $80 \%$ completos são normalmente suficientes para a maioria dos propósitos. Dados faltando em uma única região do espaço recíproco são piores que dados faltando em posições aleatórias. Se existe alguma quantidade de dados em todas as direções, então uma completeza abaixo de $80 \%$ pode ser tolerada (McRee, 1993 ). Na tabela 5.2. temos a evolução da completeza dos dados do complexo CDK2-DFP com diferentes faixas de resolução. Nela vemos que para mais alta resolução há uma queda completeza. Isto se deve ao fato que, conforme aumentamos a resolução, temos menos reflexões suficientemente intensas para serem consideradas na estatística. A completeza acumulada do conjunto de dados é dada na terceira coluna, assim temos que estes dados são $91,8 \%$ completos.

Após a coleta das imagens de oscilação passa-se a etapa de se indexar cada ponto de difração sobre cada imagem de oscilação e se medir a intensidade dos mesmos. Para se medir as intensidades usando-se as placas de imagens leva-se em consideração que estas são divididas em pequenas áreas (pixels) e somam-se as intensidade registradas em cada pixel. Deve-se também levar em consideração a radiação de fundo presente. O programa calcula um perfil médio para as reflexões usando-se caixas centradas nas posições previstas para as reflexões usando-se a matriz de orientação. A caixa definida no programa OSCILL está mostrada na figura 5.16. Desta caixa, é retirada uma certa área na altura (NRY), largura (NRX) e diagonais (NCR), formando assim duas áreas na caixa, uma 
interna às linhas pontilhadas e outra externa. A intensidade medida na área externa é considerada como background (radiação de fundo) e a intensidade medida na área interna como reflexão mais radiação de fundo, assim a intensidade devida unicamente à reflexão é obtida a pela equação:

$$
\mathrm{I}(\mathrm{hkl})=\mathrm{I}(\text { área interna })-\mathrm{I}(\text { área externa }) \text {. }
$$

Os parâmetros da caixa do perfil NCR, NRX e NRY podem ser ajustadas pelo operador de forma a se ajustarem ao ponto de difração da sua coleta de dados.

$\mathrm{Na}$ realidade, o cálculo de um perfil médio para toda a imagem é feito somente na primeira etapa para a escolha da caixa pelo usuário; após esta escolha, o programa divide a imagem em cinco regiões, uma central e quatro periféricas, e é feito um refinamento independente de cada uma destas regiões, adequando-se as coordenadas do centro da imagem $\left(\mathrm{X}_{\mathrm{cen}}, \mathrm{Y}_{\mathrm{cen}}\right)$, a distância cristal-placa de imagem (D), o ângulo ômega e os parâmetros de distorção da câmara aos pontos de difração em termos dos índices de

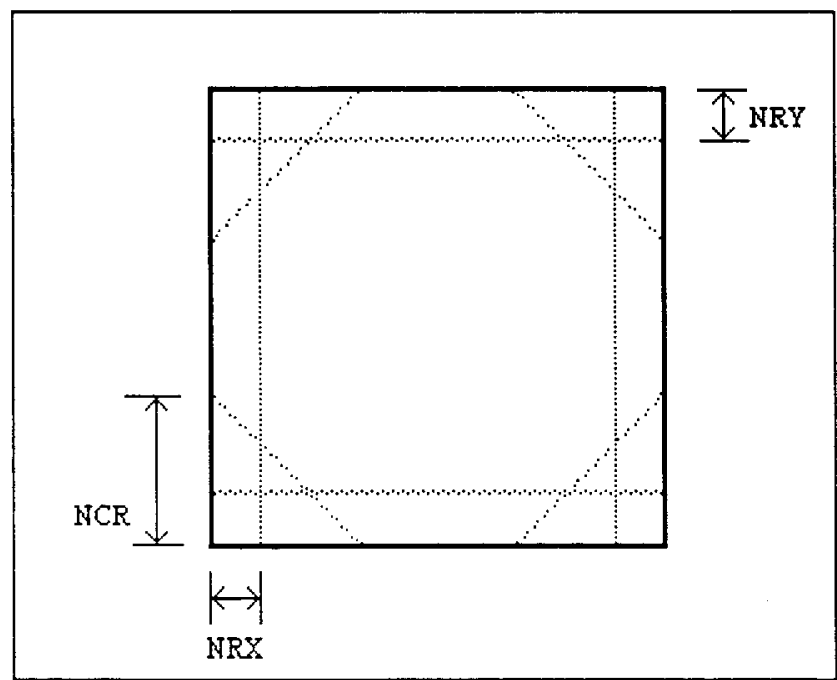

Figura 5.16. Perfil para integração das reflexões. Miller. Com este refinamento por regiões melhora-se a qualidade dos resultados, pois pode-se levar em consideração as características de cada região.

Para o uso das reflexões parciais pelo programa, é necessário primeiro que se saiba localizar quais são as reflexões parciais (Arndt \& Wonacott, 1977, pp87-89), e que estas estejam na mesma escala.

O programa faz ainda nesta etapa a correção de Lorentz (L) polarização (p). A correção de polarização surge devido ao fato que um elétron não espalha radiação ao longo de sua direção de oscilação. Para radiação não-polarizada esta correção é da seguinte forma 


$$
p=\frac{1}{2\left(1+\cos ^{2} 2 \theta\right)}
$$

A correção de Lorentz representa o tempo que uma reflexão gasta em condições de difração, enquanto está sendo girada através da esfera de Ewald. A expressão para correção de Lorentz (L) para a câmara de oscilação é da seguinte forma:

$$
\mathrm{L}=\frac{1}{\operatorname{sen} 2 \theta}
$$

onde $2 \theta$ é o ângulo de espalhamento.

No próximo passo o programa $S C A L E$ agrupa todas as reflexões integradas em um único arquivo (arquivo merge), estas reflexões ficam em ordem crescente dos índices de Miller.

Tabela 5.2. Evolução da completeza dos dados do complexo de CDK2-DFP coletadas a

\begin{tabular}{|c|c|c|c|}
\hline Resolução (Å) & $\begin{array}{l}\text { Completeza da faixa de } \\
\text { resolução (\%) }\end{array}$ & $\begin{array}{l}\text { Completeza } \\
(\%)\end{array}$ & acumulada \\
\hline 15,00 & 87,9 & 87,9 & \\
\hline 10,00 & 96,2 & 93,4 & \\
\hline 7,50 & 98,8 & 96,4 & \\
\hline 5,00 & 98,3 & 97,7 & \\
\hline 3,50 & 98,1 & 97,9 & \\
\hline 3,00 & 95,9 & 97,2 & \\
\hline 2,75 & 91,8 & 96,0 & \\
\hline 2,50 & 88,0 & 94,1 & \\
\hline 2,33 & 81,8 & 91,8 & \\
\hline
\end{tabular}
$2,33 \AA$ de resolução. 


\subsubsection{Escalonamento das imagens (Blundell \& Johnson, 1976, Fox \& Holmes, 1966).}

Dados de alta resolução para cristais de macromoléculas biológicas são coletados usando-se diversas imagens e, em muitos casos, cristais diferentes. Então, se faz necessário, que se aplique um fator de escala às diferentes imagens, ou conjunto de dados, baseando-se nas reflexões comuns entres as imagens ou conjuntos de dados. O método de Hamilton et al., (1965) tem se provado bem eficiente.

Seja I $(\mathbf{H})_{\text {I }}$ uma observação da intensidade da reflexão $\mathbf{H}$ para uma imagem, ou conjunto de dados. Nós precisamos de um conjunto de fatores de escala, $K_{i}$, para cada uma das imagens, ou conjunto de dados a ser aplicado à $\mathrm{I}(\mathbf{H})_{\mathrm{i}}$ de maneira que nós possamos determinar o melhor valor de minimos quadrados da intensidade $\mathrm{I}(\mathbf{H})$. Nas equações de mínimos quadrados (Blundell \& Johnson, 1976) é mais conveniente ter os parâmetros desconhecidos ( $\mathrm{K}_{\mathrm{i}} \mathrm{e} \mathrm{I}(\mathbf{H})_{1}$ neste caso) separados das observações de maneira que a função de minimização não é alterada quando todos $\mathrm{K}_{\mathrm{i}}$ são multiplicados por um algum fator de escala. Nós fazemos então a substituição $G_{i}=1 / K_{i}$ e resolvemos as equações em termos dos inversos dos fatores de escala. As equações observacionais ficam da seguinte forma:

$$
\phi(\mathbf{H})_{\mathrm{i}}=\sqrt{\mathrm{w}(\mathbf{H})_{\mathrm{i}}}\left(\mathrm{I}(\mathbf{H})_{\mathrm{i}}-\mathrm{G}_{\mathrm{i}} \mathrm{I}(\mathbf{H})\right)
$$

onde $\sqrt{\mathrm{w}(\mathbf{H})_{i}}$ é o peso da iésima observação e é proporcional ao inverso do desvio padrão de $\mathrm{I}(\mathbf{H})_{\mathrm{i}}$. Nós desejamos minimizar a seguinte função:

$$
\psi=\sum_{\mathbf{H i}=1}^{N} \phi(\mathbf{H})_{\mathrm{i}}^{2}
$$

onde $\mathrm{N}$ é o número de observações da reflexão $\mathbf{H}$. O melhor valor de mínimo quadrados de $\mathrm{I}(\mathbf{H})$ é encontrado a partir da condição $\partial \psi / \partial \mathrm{I}(\mathbf{H})=0$ ou:

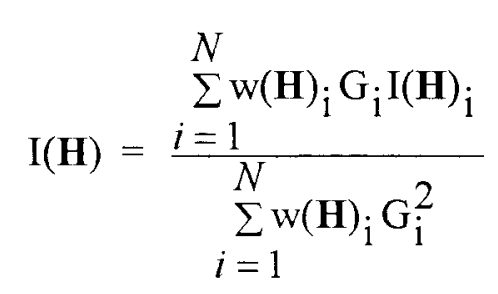

A solução das equações observacionais para os $G_{i}$ não é direta, visto que, com a substituição do valor acima de $\mathrm{I}(\mathbf{H})$, as equações tornam-se não-lineares em $\mathrm{G}_{\mathrm{i}}$. Usando-se 
procedimento para mínimos-quadrados não lineares, temos que, valores aproximados de $\mathrm{G}_{\mathrm{i}}$ ( =1 digamos) são inicialmente usados e as correções $\Delta \mathrm{G}_{\mathrm{i}}$ calculadas num processo iterativo. As equações observacionais são espandidas em séries de Taylor para valores de $\phi_{\mathrm{I}}$ em $\mathrm{G}_{\mathrm{i}}+\Delta \mathrm{G}_{\mathrm{i}}$, isto é, as equações observacionais ficam da seguinte forma:

$$
\phi(\mathbf{H})_{\mathrm{i}}=\sqrt{\mathrm{w}(\mathbf{H})_{\mathrm{i}}}\left(\mathrm{I}(\mathbf{H})_{\mathrm{i}}-\mathrm{G}_{\mathrm{i}} \mathrm{I}(\mathbf{H})\right)+\sum_{k=1}^{N} \frac{\partial \phi(\mathbf{H})_{\mathrm{i}}}{\partial \mathrm{G}_{\mathrm{k}}} \Delta \mathrm{G}_{\mathrm{k}}
$$

Desta forma $\mathrm{I}(\mathbf{H})$ e as derivadas parciais são calculadas com os valores aproximados de $G_{i}$ e as equações resultantes resolvidas para $\Delta G_{i}$ pelo procedimento usual de mínimos quadrados. Devido ao fato que os $\Delta \mathrm{G}_{\mathrm{i}}$ não são independentes, um deles deve ser colocado arbitrariamente igual a zero. Os $\mathrm{G}_{\mathrm{i}}$ são corrigidos por $\Delta \mathrm{G}_{\mathrm{i}}$ e o processo é repetido até que a correção seja muito pequena. A convergência é usalmente atingida após 10 ciclos de refinamento.

Este algorítmo está implementado no programa $S C A L E$. Este programa pode refinar também outros fatores dependentes da resolução, ou seja, uma função que é dada por $A \exp (-b(\operatorname{sen} \theta) / \lambda)$, onde $A$ e b são fatores de escala que podem ser calculados usando-se o mesmo algorítmo descrito acima.

O programa SCALE possue ainda uma rotina de pós-refinamento que permite o refinamento utilizando-se o método dos mínimos quadrados dos parâmetros calculados no início do refinamento, tais como, orientação do cristal, parâmetros de rede e da câmara, além da mosaicidade que ainda não foi refinada, e incluindo as reflexões parciais. Neste

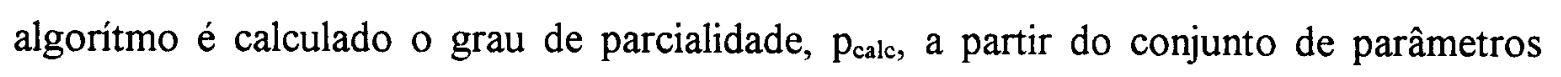
cristalinos, orientação do cristal e mosaicidade, e o grau de parcialidade observada, pobs, usando-se as seguintes equações:

$$
p_{\text {calc }}=3 q^{2}-2 q^{3}
$$

onde q é o grau de penetração na esfera de Ewald e é função dos parâmetros da cela unitária, orientação do cristal e mosaicidade ( Rossmann et al., 1979).

$$
p_{\text {obs }}=\frac{F_{h i}^{2}}{G_{i} F_{h}^{2}}
$$


onde $\mathrm{F}_{\mathrm{hi}}{ }^{2}$ é uma reflexão parcial de índices $\mathrm{hkl}, \mathrm{F}_{\mathrm{h}}$ é a melhor estimativa de uma reflexão completa hkl obtida da mesma imagem, ou de outras imagens e $G_{i}=1 / K_{i}$ é o inverso do fator de escala para a imagem $I$. Os valores de $p_{\text {calc }}$ e $p_{\text {obs }}$ são minimizados pela função $E$ como segue:

$$
\mathrm{E}=\sum \mathrm{w}\left(\mathrm{p}_{\text {calc }}-\mathrm{p}_{\mathrm{obs}}\right)^{2}
$$

onde a soma é feita sobre todas as reflexões parciais para as quais uma ou mais reflexões completas são também observadas e w é uma função peso. Quando é feita a minimização da função E faz-se na realidade o refinamento dos parâmetros da cela unitária, da orientação cristalina e mosaicidade em relação às reflexões parciais. Estes parâmetros podem ser refinados separadamente ou em conjunto. Uma vez o processo tenha convergido, pode-se usar os novos valores da orientação, parâmetros de cela e mosaicidade obtidos para se avaliar novamente as intensidades, e verificar se com os parâmetros obtidos com o pós-refinamento há uma melhora da qualidade dos dados.

Um índice simples usado para se verificar a qualidade de um conjunto de dados de difração é o $\mathrm{R}_{\text {sym }}$, que é definido pela seguinte equação:

$$
\mathrm{R}_{\text {sym }}=\frac{\sum_{i}\left|\langle\mathrm{I}\rangle-\mathrm{I}_{\mathrm{i}}\right|}{\sum_{i} \mathrm{I}_{\mathrm{i}}}
$$

onde $I_{i}$ são intensidades individuais, $<\mathrm{I}>$ é a intensidade média da reflexões relacionadas por simetria e a média é feita sobre todas as reflexões. Valores normais de $\mathrm{R}_{\text {sym }}$ são por volta de $5 \%$ e conjuntos de dados com valores de $\mathrm{R}_{\text {sym }}$ acima de $10 \%$ devem ser usados com extremo cuidado.

\subsection{Resolução (McRee, 1993)}

Um conceito que se tem usado bastante neste capítulo é o conceito de resolução. Este termo usualmente refere-se ao espaçamento interplanar (d) mínimo para o conjunto de dados em questão (equação 4.21). É assumido que o conjunto de dados é razoalvelmente completo a esta resolução. Um conjunto de dados com uma reflexão a 1,7 $\AA$ e todo o restante com um espaçamento (d) maior que $2,0 \AA$ é na verdade um conjunto de dados de resolução 2,0 $\AA$. As divisões entre alta, média e baixa resolução são um tanto 
arbitrárias, mas normalmente se aceita que um conjunto de dados com resolução de $2,5 \AA$ ou menos é de alta resolução, baixa resolução é para dados entre $4 \AA 100 \AA$, e média resolução dados em torno de $3,0 \AA$. Dados com um espaçamento (d) menor são ditos serem a uma resolução melhor.

Considerando-se um mapa de densidade eletrônica com pouco ruído a mínima distância que pode ser resolvida e de aproximadamente 0,92 da mais alta resolução. Assim, com um conjunto de dados de 1,6 $\AA$ os mapas que serão gerados terão resolução suficiente para se distinguir dois átomos de carbono que estajam separados por $1,5 \AA$.

\subsection{Informações sobre a coleta de dados dos cristais de CDK2-DFP e CDK2-}

\section{Roscovitine.}

Neste trabalho estudou-se a estrutura determinada por métodos da biocristalografia de dois cristais dos complexos CDK2-Descloroflavopiridol e CDK2Roscovitine. As principais informações referentes à coleta de dados estão na tabela 5.3.

Tabela 5.3. Resumo da informações sobre a coleta de dados usando o R-AXIS IIC.

\begin{tabular}{lll}
\hline Cristal & CDK2-DFP & CDK2-Roscovitine \\
Grupo Espacial & $\mathrm{P}_{1} 2_{1} 2_{1}$ & $\mathrm{P} 22_{1} 2_{1}$ \\
a $(\AA)$ & 71,30 & 72,31 \\
$\mathrm{~b}(\AA)$ & 72,03 & 73,07 \\
$\mathrm{c}(\AA)$ & 53,70 & 54,28 \\
Voltagem e Corrente $(\mathrm{kV} ; \mathrm{mA})$ & $50 ; 100$ & 50,100 \\
Comprimento de onda $(\AA)$ & $\mathrm{Cu} \mathrm{K}_{\alpha} 1,5418$ & $\mathrm{Cu} \mathrm{K}_{\alpha} 1,5418$ \\
Monocromatização & Cristal de Grafite & Cristal de Grafite \\
Número de cristais usados & 1 & 1 \\
Eixo aproximadamente paralelo & $\mathrm{a}$ & $\mathrm{a}$ \\
ao eixo de rotação & & \\
Resolução $(\AA)$ & 2,33 & 2,40 \\
Distância Cristal-IP (mm) & 120 & 120 \\
Ângulo de oscilação $\left({ }^{\circ}\right)$ & 2,0 & 2,0 \\
Tempo de exposição por imagem & 40 & 20 \\
(min) & & \\
Número de imagens & 46 & 45 \\
Ângulo total de rotação $\left({ }^{\circ}\right)$ & 92 & 90 \\
Número de medidas $(\mathrm{I} /(\mathrm{I})>1,0)$ & 35891 & 33067 \\
Número de reflexões únicas & 11430 & $1113+$ \\
Completeza & 91,7 & 88,5 \\
$\mathrm{R}_{\text {sym }}(\%)$ & 4.9 & 6,9 \\
& & \\
\hline
\end{tabular}


Também foram coletados dados de difração de raios $\mathrm{X}$ à baixa temperatura ( 100K), tanto em fontes síncrotrons (Stanford e Brookhaven) como em fontes convencionais, para os cristais dos complexos de CDK2 com os outros inibidores mostrados na figura 5.1. (excluindo-se roscovitine, que já havia sido resolvida com dados coletados a $4^{\circ} \mathrm{C}$ ) e os parâmetros de cela unitárias estavam bem próximos àqueles mostrados na tabela 5.3 para o complexo CDK2-DFP. Foram coletados e processados ao todo 35 conjuntos de dados de difração de raios $\mathrm{X}$ ( 5 conjuntos de dados para cada possivel complexo de CDK2 com inibidor), contudo, nenhum destes 7 complexos nos 35 conjuntos de dados de difração de raios $\mathrm{X}$, apresentou densidade eletrônica para o inibidor após resolvida e refinada a estrutura. Assim, omitimos a apresentação detalhada das informações sobre as coletas de dados de raios $\mathrm{X}$ destes cristais, visto que, os mesmos não nos forneceram informações experimentais a respeito da sua interação com CDK2. 


\section{CAPÍTULO 6.}

\section{ESTRUTURAS DA CDK2 HUMANA EM COMPLEXO COM DOIS INIBIDORES.}

\subsection{Introdução.}

A importância das Quinases Dependentes de Ciclina (CDKs) no controle da divisão celular as tornam um alvo promissor para o estudo de pequenas moléculas inibidoras que podem modificar o grau de proliferação das células. A descoberta de inibidores específicos de CDKs tais como os flavonas polihidroxiladas (Losiewicz et al., 1994), os derivados de adenina e outros (Meijer et al., 1991) abriu o caminho para a investigação e desenho de drogas anti-câncer. Um novo derivado de flavona, descloroflavopiridol (DFP), é um potente inibidor de CDKs e a forma clorada deste inibidor, o flavopiridol, está atualmente em fase 1 de testes clínicos como droga contra tumores cancerígenos de mama. Nós determinamos a estrutura de CDK2 em complexo com este inibidor e refinamos a estrututa até um $\mathrm{R}_{\text {fator }}$ de $20,3 \%$ (Azevedo, et al., 1996). Nós também determinamos a estrutura de CDK2 complexada com um inibidor derivado de adenina, o Roscovitine e sua estrutura foi refinada até um $\mathrm{R}_{\text {fator }}$ de $18,0 \%$. Para se resolver a estrutura do complexo CDK2-DFP usamos o método da substituição molecular, que apresentamos a seguir.

\subsubsection{Substituição molecular (McRee, 1993, Brünger, 1990, Brünger, 1992).}

O método de substituição molecular é um dos métodos disponíveis para se resolver o problema da fase ( seção 4.11). Neste método, uma estrutura conhecida homóloga é ajustada na cela unitária de uma estrutura desconhecida e as fases são usadas como uma primeira aproximação para as fases da estrutura desconhecida. Uma procura em seis dimensões (ou graus de liberdade) é necessária para se ajustar o modelo. Esta procura pode ser dividida em duas procuras, uma procura rotacional seguida por uma procura translacional. Tal procedimento colocado nos algorítmos de substituição molecular economiza um tempo considerável de CPU. Por exemplo, considere que a procura em uma dimensão toma $10 \mathrm{~s}$ de tempo de CPU, se dividirmos em duas procuras 
teremos um tempo total de $10^{3}+10^{3}=2000 \mathrm{~s}$, que é bem menor que o tempo de uma procura única nas seis dimensões $10^{6} \mathrm{~s}$, ou mais de 11 dias de CPU. O modelo inicial a ser usado na procura deve ser o mais próximo próximo possível da macromolécula que se quer resolver, no caso de proteínas, uma identidade superior ou igual a $50 \%$ entre o modelo e a estrutura a ser resolvida normalmente será suficiente. O maior problema com procuras usando-se modelos com baixa identidade é que uma vez que a solução seja obtida, as fases serão uma estimativa grosseira das fases verdadeiras, o que pode causar problemas durante o refinamento destas coordenadas. Em muito casos, o modelo representa somente parte da estrutura a ser resolvida, como no caso de complexos com duas ou mais proteinas diferentes, em que se possue modelo somente para um dos componentes do complexo (Russo et al., 1996).

A procura rotacional é feita no espaço de Patterson, este espaço é obtido por sintese de Fourier tomando-se como termos o quadrado dos fatores de estrutura e assim temos que a função de Patterson $\mathrm{P}(\mathbf{u})$ é da seguinte forma:

$$
\mathrm{P}(\mathbf{u})=\frac{1}{\mathrm{~V}} \sum_{\mathbf{H}}|\mathrm{F}(\mathbf{H})|^{2} \exp (2 \pi \text { i H.u })
$$

onde $\mathrm{V}$ é o volume da cela unitária, $\mathrm{F}(\mathbf{H})$ o fator de estrutura, $\mathbf{H}$ é um vetor posição do espaço recíproco e u um vetor posição no espaço de Patterson. Pode-se mostrar que no espaço de Patterson temos que os máximos correspondem aos vetores entre os átomos da cela unitária ao invés das posições absolutas dos átomos na cela unitária. Se considerarmos o mapa de Patterson de uma macromolécula em uma cela unitária, em geral, os vetores menores serão vetores intramoleculares, e os maiores os vetores intermoleculares. Como a função de Patterson é a transformada de Fourier de $\mathrm{F}(\mathbf{H})^{2}$ esta pode ser calculada a partir de um conjunto de dados de difração, sem nenhuma informação sobre a fase. Numa função de rotação (Rossmann \& Blow, 1962) nós queremos considerar somente os vetores intramoleculares, visto que, todos os vetores no mapa de Patterson começam na origem, os vetores mais próximos à origem serão, em geral, os intramoleculares. Escolhendo-se cuidadosamente o raio máximo no espaço de Patterson, onde será feita a procura rotacional, melhora-se as chances de se achar a rotação certa. $\mathrm{O}$ raio máximo no espaço de Patterson é um dos parâmetros de entrada para se efetuar a 
procura rotacional usando-se o programa X-PLOR (Brünger, 1992). Um outro parâmetro a ser escolhido é a faixa de resolução a ser usada no cálculo dos mapas de Patterson. Reflexões de mais alta resolução (acima de 3,5 $\AA$ ) diferem marcadamente, mesmo entre estruturas com alta homologia, visto que, tais reflexões trazem informações sobre os detalhes estruturais. Reflexões de baixa resolução refletem aspectos relacionados com a estrutura secundária. As reflexões com resolução abaixo de $10 \AA$ são influênciadas pelo empacotamento cristalino e pelo arranjo das moléculas de solvente, o que é mais dependente de um arranjo de empacotamento particular do que da estrutura individual da macromolécula. Desta forma, a faixa de resolução usada na procura rotacional é usualmente entre $10-3,5 \AA$, com a faixa de 8-4 $\AA$ sendo bem comum. Na prática várias faixas de resolução podem ser tentadas.

$\mathrm{Na}$ implementação do algorítmo de procura rotacional no programa X-PLOR temos as seguintes etapas. Primeiro o programa calcula um mapa de Patterson estacionário, chamado mapa P2, a partir das intensidades observadas usando transformada rápida de Fourier sobre uma grade especificada pelo usuário, em seguida o mapa de Patterson da estrutura modelo a ser rotacionado, chamado mapa P1, é calculado a partir das coordenadas do modelo inicial rotacionadas pela matriz $\mathbf{C}$. Os vetores de Patterson são rotacionados usando ângulos de Euler $\left(\theta_{1}, \theta_{2}, \theta_{3}\right)$ como definido por Rossmann \& Blow (1962), ou ângulos de Euler pseudo-ortogonais como definido por Lattman (Brünger, 1992), ou ainda ângulos polares esféricos ( $\psi, \phi, \kappa)$. Os ângulos de Lattman são relacionados aos ângulos de Euler por:

$$
\theta_{+}=\theta_{1}+\theta_{3} ; \theta_{.}=\theta_{1}+\theta_{3} \text { e } \theta_{2}=\theta_{2}
$$

Os ângulos $\theta_{2}$ são amostrados em um intervalo constante $\Delta$, definido pelo usuário, este ângulo será o passo com o qual será varrido uma unidade assímetrica da função de rotação. Seguindo a notação adotada por Lattman (Brünger, 1992), temos que o intervalo variável para $\theta_{+}$é dado por $\Delta / \cos \left(\theta_{2} / 2\right)$, e o intervalo variável para $\theta$. é dado por $\Delta / \operatorname{sen}\left(\theta_{2} / 2\right)$. Para os ângulos de Euler e polares esféricos, o intervalo de amostragem da função de rotação é constante $(\Delta)$ para as três variáveis angulares. Como já foi mencionado, a procura rotacional deve estar restrita a uma unidade assimétrica da função de rotação (Rao, Jih \& Hartsuck, 1980). O programa X-PLOR usa a convenção do artigo 
de Rao et al., em que a simetria do mapa rotacionado P1 é 1 (International tables for Xray crystallography, Vol. A, 1983), e a do mapa P2 é a simetria de Patterson do grupo espacial da estrutura a ser determinada. A tabela 6.1. mostra as unidades assimétricas a serem varridas na procura de rotação, quando o mapa P1 é mantido fixo e o mapa P2 rotacionado.

Tabela 6.1. Unidades assímetricas a serem usadas para a procura rotacional.

\begin{tabular}{|c|c|c|}
\hline Grupo de Patterson & $\theta_{1}, \theta_{2}, \theta_{3}$ & $\theta_{+}, \theta_{.}, \theta_{2}$ \\
\hline \multirow[t]{3}{*}{$\overline{1}$} & $0 \leq \theta_{1}<2 \pi$ & $0 \leq \theta_{+}<4 \pi$ \\
\hline & $0<\theta_{2} \leq \pi$ & \\
\hline & $0 \leq \theta_{3}<2 \pi$ & $0 \leq \theta_{-} \leq 2 \pi$ \\
\hline \multirow[t]{3}{*}{$2 / \mathrm{m}$ com $\mathrm{b}$ único } & $0 \leq \theta_{1}<2 \pi$ & $0 \leq \theta_{+}<4 \pi$ \\
\hline & $0<\theta_{2} \leq \pi / 2$ & \\
\hline & $0 \leq \theta_{3}<2 \pi$ & $0 \leq \theta . \leq 2 \pi$ \\
\hline \multirow[t]{3}{*}{$2 / \mathrm{m}$ com cúnico } & $0 \leq \theta_{1}<2 \pi$ & $0 \leq \theta_{+}<4 \pi$ \\
\hline & $0<\theta_{2} \leq \pi$ & \\
\hline & $0 \leq \theta_{3}<\pi$ & $0 \leq \theta_{-} \leq \pi$ \\
\hline \multirow[t]{3}{*}{$\mathrm{mmm}$} & $0 \leq \theta_{1}<2 \pi$ & $0 \leq \theta_{+}<4 \pi$ \\
\hline & $0<\theta_{2} \leq \pi / 2$ & \\
\hline & $0 \leq \theta_{3}<\pi$ & $0 \leq \theta_{-} \leq \pi$ \\
\hline \multirow[t]{3}{*}{$4 / \mathrm{m}$} & $0 \leq \theta_{1}<2 \pi$ & $0 \leq \theta_{+}<4 \pi$ \\
\hline & $0<\theta_{2} \leq \pi$ & \\
\hline & $0 \leq \theta_{3}<\pi / 2$ & $0 \leq \theta_{-} \leq \pi / 2$ \\
\hline \multirow[t]{3}{*}{$4 / \mathrm{mmm}$} & $0 \leq \theta_{1}<2 \pi$ & $0 \leq \theta_{+}<4 \pi$ \\
\hline & $0<\theta_{2} \leq \pi / 2$ & \\
\hline & $0 \leq \theta_{3}<\pi / 2$ & $0 \leq \theta_{-} \leq \pi / 2$ \\
\hline \multirow[t]{3}{*}{$\overline{3}$} & $0 \leq \theta_{1}<2 \pi$ & $0 \leq \theta_{\perp}<4 \pi$ \\
\hline & $0<\theta_{2} \leq \pi$ & \\
\hline & $0 \leq \theta_{3}<2 \pi / 3$ & $0 \leq \theta_{-} \leq 2 \pi / 3$ \\
\hline \multirow[t]{3}{*}{$\overline{3} / \mathrm{m}$} & $0 \leq \theta_{1}<2 \pi$ & $0 \leq \theta_{+}<4 \pi$ \\
\hline & $0<\theta_{2} \leq \pi / 2$ & \\
\hline & $0 \leq \theta_{3}<2 \pi / 3$ & $0 \leq \theta_{.} \leq 2 \pi / 3$ \\
\hline \multirow[t]{3}{*}{$6 / \mathrm{m}$} & $0 \leq \theta_{1}<2 \pi$ & $0 \leq \theta+<\pi \pi$ \\
\hline & $0<\theta_{2} \leq \pi$ & \\
\hline & $0 \leq \theta_{3}<\pi / 3$ & $0 \leq 0.5 \pi / 3$ \\
\hline \multirow[t]{3}{*}{$6 / \mathrm{mmm}$} & $0 \leq \theta_{1}<2 \pi$ & $0 \leq \theta<4 \pi$ \\
\hline & $0<\theta_{2} \leq \pi / 2$ & \\
\hline & $0 \leq \theta_{3}<\pi / 3$ & $U \leq \theta, \leq \pi / 3$ \\
\hline
\end{tabular}


Para cada orientação definida pela matriz de rotação $\mathbf{C}$ é calculada um função de rotação $\mathrm{RF}$ :

$$
\mathrm{RF}(\mathbf{C})=\int_{V} \mathrm{P}_{\text {obs }}(\mathbf{u}) \mathrm{P}_{\text {model }}(\mathbf{C . u}) \mathrm{d} \mathbf{u}
$$

onde $\mathrm{P}_{\mathrm{obs}}$ é a função de Patterson do cristal calculada a partir dos fatores de estrutura observados, $\mathrm{P}_{\text {model }}$ é a função de Patterson calculada do modelo após rotacionado pela matriz C, u é um vetor no espaço de Patterson e V é o volume da cela unitária do cristal cuja a estrutura é deconhecida. Esta função, RF, terá um máximo quando os picos das duas funções de Patterson se superpuserem, ao menos parcialmente. Quando isto acontecer teremos que as coordenadas do modelo rotacionadas pela matriz $\mathbf{C}$, serão as coordenadas da solução. O programa X-PLOR gera um arquivo de saida (rotation.rf) após terminada a procura rotacional, onde estão, listados os ângulos de Euler $\left(\theta_{1}, \theta_{2}, \theta_{3}\right)$ e o valor da função RF calculada para estas coordenadas angulares em ordem decrescente de RF, de forma, que o melhor modelo, nos casos favoráveis, é aquele encontrado na primeira linha do arquivo de saída. Contudo, este modelo pode passar por um passo posterior de refinamento, baseado na correlação de Patterson (PC). Neste método o modelo é tratado como um corpo-rígido e sua orientação (rotação mais translação) é refinada de forma a minimizar a função $\mathrm{E}_{\text {total }}\left(\mathbf{C}, \mathbf{C}_{\mathbf{i}}, \mathbf{t}_{\mathbf{i}}\right)$ definida como:

$$
\mathrm{E}_{\text {total }}=\left(1-\operatorname{PC}\left(\mathbf{C}, \mathbf{C}_{\mathbf{i}}, \mathbf{t}_{\mathbf{i}}\right)\right)
$$

onde a PC é o coeficiente de correlação entre $\left|E_{o b s}\right|^{2}$ e $\left|E_{\text {model }}\right|^{2}$ e é dada por:

$$
\operatorname{PC}\left(\mathbf{C}, \mathbf{C}_{\mathbf{i}}, \mathbf{t}_{\mathbf{i}}\right)=\frac{\sum \mathrm{ab}-\left(\sum \mathrm{a} \sum \mathrm{b}\right) / \mathrm{N}}{\left\{\left[\sum \mathrm{a}^{2}-\left(\sum \mathrm{a}\right)^{2} / \mathrm{N}\right]^{1 / 2}\right\}\left\{\left[\sum \mathrm{b}^{2}-\left(\sum \mathrm{b}\right)^{2} / \mathrm{N}\right]^{1 / 2}\right\}}
$$

com a $=\left|E_{\text {obs }}\right|^{2}$ e $b=\left|E_{\text {model }}\left(\mathbf{C}, \mathbf{C}_{\mathbf{i}}, \mathbf{t}_{\mathbf{i}}\right)\right|^{2}$ onde as somatárias são feitas sobre o conjunto de reflexões observadas. $E_{\text {obs }}$ representa os fatores de estrutura normalizados observados, e $E_{\text {model }}$ os fatores de estrutura nomalizados do modelo. Os fatores de estrutura normalizados são dados pela seguinte equação: 


$$
E(\mathbf{H})^{2}=\frac{|\mathrm{F}(\mathbf{H})|^{2}}{\varepsilon \sum_{\mathrm{j}=1}^{N} \mathrm{f}_{\mathrm{j}}^{2}}
$$

onde $\mathbf{H}$ é um vetor do espaço recíproco $\mathrm{f}_{\mathrm{j}}$ os fatores de espalhamento atômico (equação 4.4) e $\varepsilon$ é um inteiro que é geralmente 1, mas pode assumir outros valores para conjuntos especiais de reflexões em certos grupos espaciais (Stout \& Jensen, 1989 p. 254). O coeficiente de correlação (função PC) terá valores de -1 ( correlação inversa perfeita) passando por 0 (sem correlação) e com máximo de 1 ( correlação perfeita), assim a minimização da função $E_{\text {total }}$ leva à maximização da função $\mathrm{PC}$, ou seja, os parâmetros serão ajustados de forma que haja uma máxima correlação entre $\left|E_{\text {obs }}\right|^{2}$ e $\left|E_{\text {model }}\right|^{2}$. É também possivel, neste tipo de refinamento, se dividir a macromolécula em dois ou mais grupos e refinar cada orientação, $C_{i}$, e translação, $\mathbf{t}_{\mathbf{i}}$, individualmente. Todas as orientações listadas no arquivo rotation.rf são refinadas desta forma, e é gerado um novo arquivo de saida ( filter.list) que contém os resultados do refinamento PC ( Patterson Correlation), este arquivo lista as coordenadas angulares de Euler antes e após o refinamento PC bem como os coeficientes de correlação PC. O mais alto pico do arquivo, ou seja, o mais alto valor da função PC, fornece a melhor orientação para o modelo inicial. O próximo passo é achar a translação do modelo, ou seja, posicionar o modelo rotacionado na melhor posição possível dentro da cela unitária da estrutura a ser determinada.

O programa X-PLOR utiliza um algoritmo para a procura translacional onde os coeficientes de correlação (equação 6.5) são calculados entre $\left|E_{o b s}\right|^{2}$ e $\left|E_{\text {model }}\right|^{2}$, como na procura rotacional, só que agora o modelo inicial é aquele obtido para o mais alto pico do refinamento PC, e será transladado para diferentes pontos dentro da cela unitária, e para cada um destes pontos será calculado um coeficiente de correlação. O usuário definirá o passo a ser dado em cada uma das direções onde será feita a procura translacional. A região a ser varrida na procura de translação é definida por Hirshfeld, (1968) e é normalmente maior que a unidade assimétrica do grupo espacial da estrutura a ser determinada. Em casos favoráveis, pode-se definir uma região bem menor a ser varrida 
pela procura translacional, como no caso da resolução da estrutura do complexo CDK2DFP (Azevedo et al., 1996). No final da procura translacional tem-se um lista com os coeficientes de correlação calculados nos pontos espaçados em intervalos definidos pelo usuário dentro da região de interesse. O programa X-PLOR gera um arquivo (translatio.log) onde temos em cada linha as coordenadas ortogonais e fracionárias do ponto e o coeficiente de correlação calculado neste ponto, a lista está em ordem decrescente de coeficientes correlação, de forma que, a melhor solução é a primeira da lista. A figura 6.1. ilustra os principais passos do processo de substituição molecular como implementado no programa X-PLOR. Como último passo é realizado um refinamento de corpo-rígido da melhor solução, os procedimentos de refinamento de corpo-rígido, posicional e simulated annealing são descritos na seção 6.3 ..

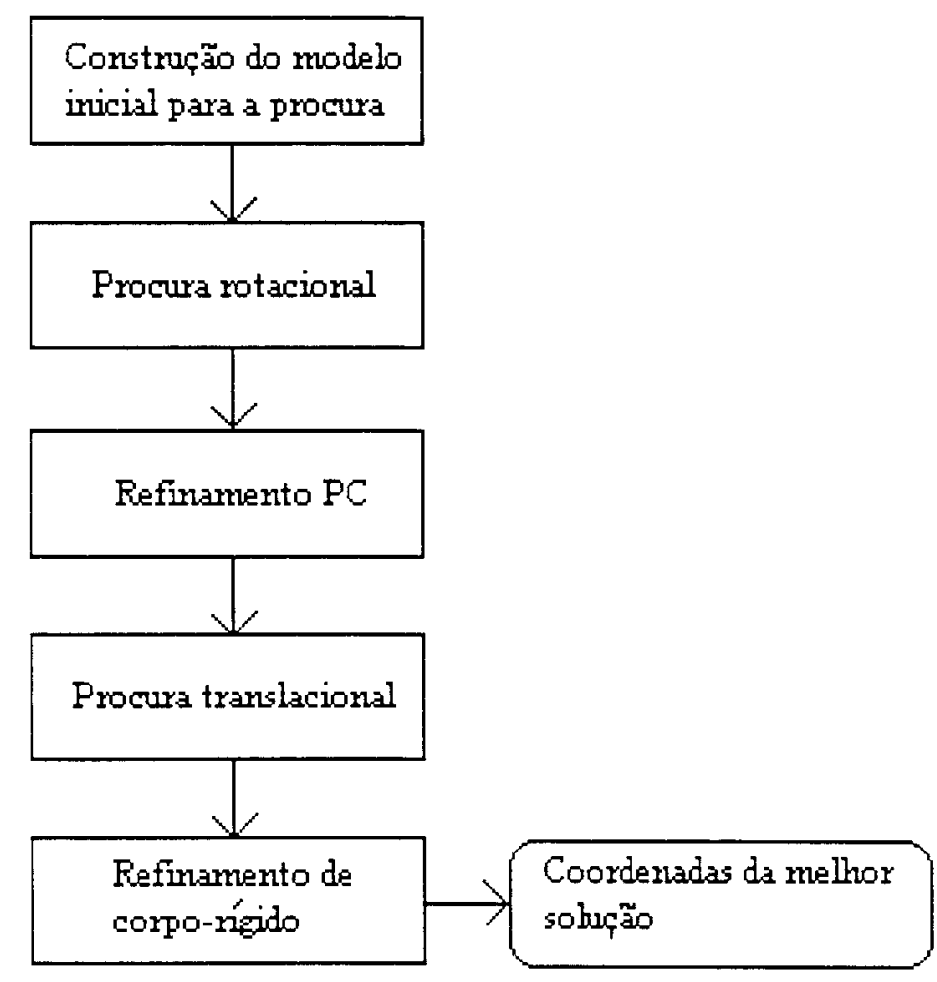

Figura 6.1. Substituição molecular. Principais passos do algoritmo de substituição molecular implementado no programa X-PLOR (Brünger, 1992). 


\subsubsection{Determinação da estrutura do complexo CDK2-DFP (Azevedo et al., 1996).}

Os cristais de CDK2-DFP eram do mesmo grupo espacial do cristal de CDK2 nativa ( $\mathrm{P} 2{ }_{1} 2_{1} 2_{1}$ ), mas como a coleta de dados do complexo foi feita à temperatura de $100 \mathrm{~K}$ os parâmetros da cela unitária variaram de $\mathrm{a}=73,14 \AA$, b=72,72 $\AA$ e $\mathrm{c}=54,25 \AA$ para $\mathrm{a}=71,30 \AA, \mathrm{b}=72,03 \AA$ e $\mathrm{c}=53,70 \AA$. Inicialmente tentamos refinar o modelo da CDK2 nativa sem as moléculas de água ( De Bondt et al., 1993) como um corpo rígido contra os dados experimentais do complexo CDK2-DFP usando o procedimento de refinamento por corpo-rígido do pacote de programas X-PLOR (Brünger, 1992). Tal tentativa não foi bem sucedida, o $\mathrm{R}_{\text {factor }}$ do complexo CDK2-DFP baixou de $52,3 \%$ para $46,7 \%$ com dados entre 8,0 a $3,0 \AA$, indicando que os cristais possuem um empacotamento diferente do cristal de CDK2 nativa. Para resolver a estrutura era necessário o uso do método de substituição molecular. Contudo, nós não esperávamos grandes diferenças entre as estruturas do complexo CDK2-DFP e da CDK2 nativa, visto que, o complexo CDK2DFP foi obtido embebendo-se os cristais de CDK2 nativa com uma solução do inibidor (seção 5.2). Assim, ao invés de usar o procedimento padrão de substituição molecular completo (figura 6.1), nós realizamos somente uma procura translacional como implementada no programa X-PLOR. Nós também restringimos a procura translacional a uma pequena parte da cela unitária, de $-0,05$ a 0,05 em $x$, y e $z$ em coordenadas fracionárias com passos de $0,8 \AA$, ao invés de realizar a procura tranlacional em metade de a, b e c, como definida por Hirshfeld, (1968) para a procura translacional do grupo espacial $\mathrm{P} 2{ }_{1} 2_{1} 2_{1}$. Tal procedimento economiza um tempo considerável de $\mathrm{CPU}$, e se provou eficaz neste caso. Se considerarmos, por exemplo, que é gasto $10 \mathrm{~s}$ de CPU para se varrer $10 \%$ de uma direção da cela unitária na procura translacional, ou seja, de $-0,05$ a 0,05 em coordenadas fracionárias, teremos então $10^{3} \mathrm{~s}$, para se varrer de $-0,05$ a 0,05 nas três direções $x, y$ e $z$. Se tivéssemos usado a região da cela unitária como definida por Hirshfeld, (1968) teríamos gasto um tempo de CPU de $(5 \times 10)^{3}$, ou $125 \times 10^{3}, 125$ vezes maior que o tempo de CPU gasto limitando-se a $-0,05$ a 0,05 em cada região. O mais alto pico encontrado na procura translacional com a região limitada ( de $-0,05$ a 0,05 em coordenadas fracionárias), estava em $x=-0,036, y=-0,007$ e $z=-0,007$, em coordenadas fracionárias. Neste estágio mapas de densidade eletrônica de $F_{o b s}-F_{c a l c}$, com as fases do 
modelo transladado sem as moléculas de água foram calculados. Tal mapa foi claro e mostrou uma densidade eletrônica nítida para o inibidor DFP ligado ao bolso de ligação de ATP. O próximo passo é o refinamento da estrutura, que descreveremos a seguir.

\subsection{Refinamento das coordenadas (McRee, 1993, Brünger, 1992, Brünger, 1991).}

Os principais passos para o refinamento das coordenadas de uma macromolécula usando o programa X-PLOR está mostrado na figura 6.2, e serão discutidos a seguir.

O primeiro passo, que não é um refinamento, é a geração das informações moleculares da estrutura que terá suas coordenadas refinadas. Estas informações são divididas em dois arquivos, um com a topologia da macromolécula e outro com os parâmetros químicos. As informações sobre a topologia incluem as massas dos átomos, as ligações (conectividade), os ângulos de ligação, os ângulos diédricos, os tipos de átomos, a carga elétrica, as ligações de hidrogênio etc... $\mathrm{O}$ arquivo de parâmetros químicos armazena as constantes a serem usadas no cálculo da função energia ( $\left.E_{\text {total }}\right)$, que será minimizada durante o refinamento. Estes dois arquivos são gerados a partir das coordenadas em formato PDB (Protein Data Bank) do modelo a ser refinado.

A seguir realiza-se o refinamento de corpo-rígido que é o processo de refinamento das posições de grupos rígidos de átomos contra as intensidades observadas. $\mathrm{O}$ modelo a ser refinado pode ser dividido em um ou mais grupos rígidos. Para cada grupo é possível refinar até seis parâmetros, três rotações e três translações. A função minimizada é definida na equação 6.7

O passo seguinte é o refinamento posicional que usa como modelo inicial as coordenadas de saida do refinamento de corpo-rígido. O programa X-PLOR usa o método do gradiente conjugado de Powell (1977). A função energia minimizada no algorítmo é dada por:

$$
\begin{aligned}
\mathrm{E}_{\text {total }}= & \mathrm{w}_{\mathrm{A}} \sum \mathrm{E}_{\text {cristal }}+\mathrm{w}_{\mathrm{B}} \sum \mathrm{E}_{\text {bond distances }}+{ }^{\mathrm{w}_{C}} \sum \mathrm{E}_{\text {bond angles }} \\
& +\mathrm{w}_{\mathrm{D}} \sum \mathrm{E}_{\text {Torsion angles }}+{ }^{\mathrm{w}_{\mathrm{E}}} \sum \mathrm{E}_{\text {non - bonded contacts }} \\
& +{ }_{\mathrm{w}} \sum \mathrm{w}_{\text {planar groups }}+{ }^{\mathrm{w}_{\mathrm{G}}} \sum \mathrm{E}_{\text {chiral volumes }}
\end{aligned}
$$


onde os termos ws são usados para um esquema de pesos relativo para os diferentes termos de energia. A energia do termo cristalográfico $E_{\text {cristal vem da diferença entre os }}$ fatores de estrututa observados $\left(F_{\text {obs }}\right)$ e os calculados $\left(F_{\text {calc }}\right)$. Os outros termos estereoquímicos são calculados considerando-se a diferença entre o valor real (aquele obtido da estrutura que está sendo refinada) e valores ideais, de forma que, quando átomos se desviam do valor ideal ocorre um aumento no termo da energia. Os valores ideais foram tabulados para proteínas e ácidos nucléicos por meio do exame da estrutura de pequenas moléculas de amino-ácidos, peptídios, nucleotídeos e outros compostos similares. O programa X-PLOR fornece arquivos com a geometria de todos amino-ácidos, alguns nucleotídeos e moléculas de água. As informações sobre nucleotídeos não convencionais, tais como aqueles encontrados nas estruturas de tRNA ( Blackburn \& Gait, 1996), não estão disponíveis no pacote X-PLOR, ao menos até a versão 3.1. A opção para refinamento destas estruturas é o programa CORELS ( Sussman, 1985). O programa $X-P L O R$ adiciona um termo eletrostático na função energia $E_{\text {total, para os grupos }}$ carregados presentes na macromolécula. Durante cada ciclo de refinamento o programa $\mathrm{X}$-PLOR calcula dois índices de discordância, definidos a seguir. $\mathrm{O} \mathrm{R}_{\mathrm{factor}}$ é definido como segue:

$$
\mathrm{R}_{\text {factor }}=\frac{\sum_{\mathbf{h}}\left|\mathrm{F}_{\text {obs }}(\mathbf{H})-\mathrm{F}_{\text {calc }}(\mathbf{H})\right|}{\sum_{\mathbf{h}} \mathrm{F}_{\mathrm{obs}}(\mathbf{H})}
$$

onde a somatória é feita sobre todas as reflexões $\mathbf{H}$, dentro da faixa de resolução definida no refinamento, $F_{\text {obs }}$ é o fator de estrutura observado e $F_{\text {calc }}$ o fator de estrutura calculado (equação 4.7) a partir das coordenadas do modelo que está sendo refinado. Este índice, $\mathrm{R}_{\text {factor, }}$ mostra a concordância entre os fatores de estrutura observados e calculados, e é mais baixo para as estruturas mais próximas aos dados experimentais. Contudo, diversos procedimentos de refinamento podem levar o $\mathrm{R}_{\text {factor }}$ a valores bem baixos (abaixo de $20 \%$ ). Entre estes procedimentos podemos citar o de aumentar o número de moléculas de água acima do necessário, que podem de forma artificial diminuir o $\mathrm{R}_{\text {factor }}$. Um outro índice de concordância, bem mais robusto, entre os fatores de estrutura observados e calculados é chamado de $\mathrm{R}_{\text {free }}$. Este índice é calculado da mesma forma que o $\mathrm{R}_{\text {factor }}$ só que usa somente 
parte das reflexões do conjunto de dados, digamos $10 \%$ das reflexões são deixadas fora do refinamento. Os valores de $\mathrm{R}_{\text {factor }} \mathrm{e} \mathrm{R}_{\text {free }}$ podem ser calculados para cada ciclo de refinamento de forma que é possível acompanhar se o processo está convergindo para bons índices de concordância. Geralmente $\mathrm{R}_{\text {free }}$ abaixo de $35 \%$ são indicativos que a estrutura está de alguma forma correta, necessitando algum refinamento. Estrutura com $\mathrm{R}_{\mathrm{free}}$ muito acima de $35 \%$ após vários ciclos de refinamento indicam que grande parte da estrutura está errada, necessitando grande inspeção, para o seu refinamento.

Uma vez que o refinamento posicional tenha convergido, o passo seguinte é o refinamento de simulated annealing ou de dinâmica molecular. Se o modelo inicial não difere muito da estrutura real o refinamento posicional normalmente converge para a solução correta, entretanto, se as distâncias entre os átomos no modelo e na estrututa real são muito grandes o refinamento posicional pode ficar aprisionado em um mínimo local. Para sair do mínimo local, usa-se a técnica de dinâmica molecular, que permite a superação de barreiras energéticas da função $E_{\text {total }}$ (Brünger, 1991). Na dinâmica molecular o comportamento dinâmico de um sistema de partículas, neste caso átomos, é simulado.

O cálculo da dinâmica molecular começa com a atribuição de velocidades aos átomos da macromolécula, estas velocidades são derivadas de uma distribuição de Maxwell a uma dada temperatura. Num tempo, $t=0 \mathrm{~s}$, os átomos estão em uma

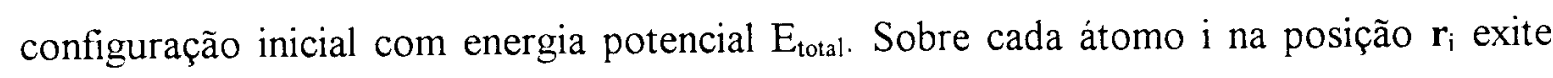
uma força $f_{i}$ agindo que é a derivada da energia potencial, $f_{i}=-\partial E_{\text {total }} / \hat{c} \mathbf{r}_{\mathrm{i}}$. Da mecânica Newtoniana temos, $f_{i}=m_{i} d^{2} \mathbf{r}_{i} / d t^{2}$ e a aceleração $d^{2} r_{i} / d t^{2}$ para o átomo $i$ de massa $m_{i}$ pode ser calculada e então aplicada. Após um curto intervalo de tempo $\Delta \mathrm{t}$, na faixa de femtosegundos ( $1 \mathrm{fs}=10^{-15} \mathrm{~s}$ ), o processo é repetido com os átomos em novas posições. Se o número de passos for suficiente, entre $10^{3}$ e $10^{4}$ passos, um novo mínimo da energia potencial $E_{\text {total }}$ será atingido. Teremos também conseguido informações sobre o comportamento dinâmico dos átomos na estrutura, o que revela partes flexiveis presentes na macromolécula. Se a temperatura do sistema é elevada a um valor mais alto, mais átomos terão velocidades maiores e uma energia cinética mais alta e poderão superar barreiras energéticas

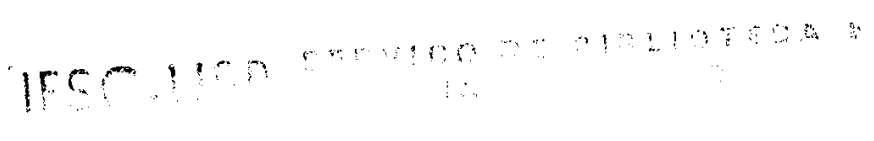


A idéia básica da dinâmica molecular, como um método superior de refinamento, é elevar a temperatura do sistema alta o suficiente, entre 1000 e $4000 \mathrm{~K}$, e então resfriá-lo lentamente para que a energia se aproxime do mínimo. A seguir se processa mais alguns passos de refinamento posicional.

A coordenadas refinadas são usadas agora para gerar mapas de densidade eletrônica ( equação 4.22). No estudo dos complexos CDK2 com inibidores usamos dois tipos de mapas de densidade eletrônica, os mapas $F_{o b s}-F_{c a l c}$, onde $F_{o b s}$ é o fator de estrutura observado e $F_{\text {calc }}$ o fator de estrutura calculado, as fases $\alpha_{\text {calc }}$ são aquelas calculadas a partir do modelo refinado. Este tipo de mapa é particularmente útil na localização de partes da estrutura que não fazem parte do modelo, tais como ligantes e moléculas de águas, que não estão ainda na estrutura do modelo refinado. Foi a partir deste tipo de mapa que localizamos os inibidores ligados ao sítio de ligação de ATP na estrutura de CDK2. A densidade eletrônica é calculada usando-se a equação 4.22 e o algorítmo da transformada de Fourier Rápida (Drenth, 1994), o fator de estrututa $F(h k l)$ da equação 4.22 é substituído pela diferença, $\left(\left|F_{\text {obs }}\right|-\left|F_{\text {calc }}\right|\right) \exp \left(2 \pi i \alpha_{\text {calc }}\right)$. O outro tipo

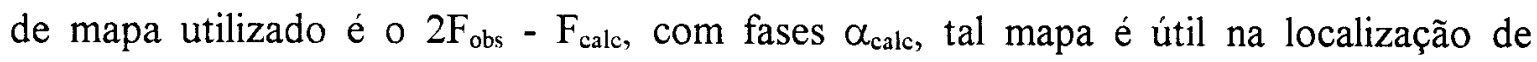
pequenos desvios das cadeias laterais e para a observação do aspecto geral da estrutura. Tal visualização é feita com a superposição das coordenadas do modelo refinado com o mapa de densidade eletrônica em terminais gráficos utilizandos pacotes de programas tais como FRODO ( Jones, 1978) e O ( Jones et al., 1991). Após os ajustes feitos no modelo, novo ciclo de refinamento deve ser realizado, até que se tenham adicionado todos os ligantes e todas moléculas de água ao modelo e o $\mathrm{R}_{\text {frec }}$ e o $\mathrm{R}_{\text {factor }}$ tenham convergido. 


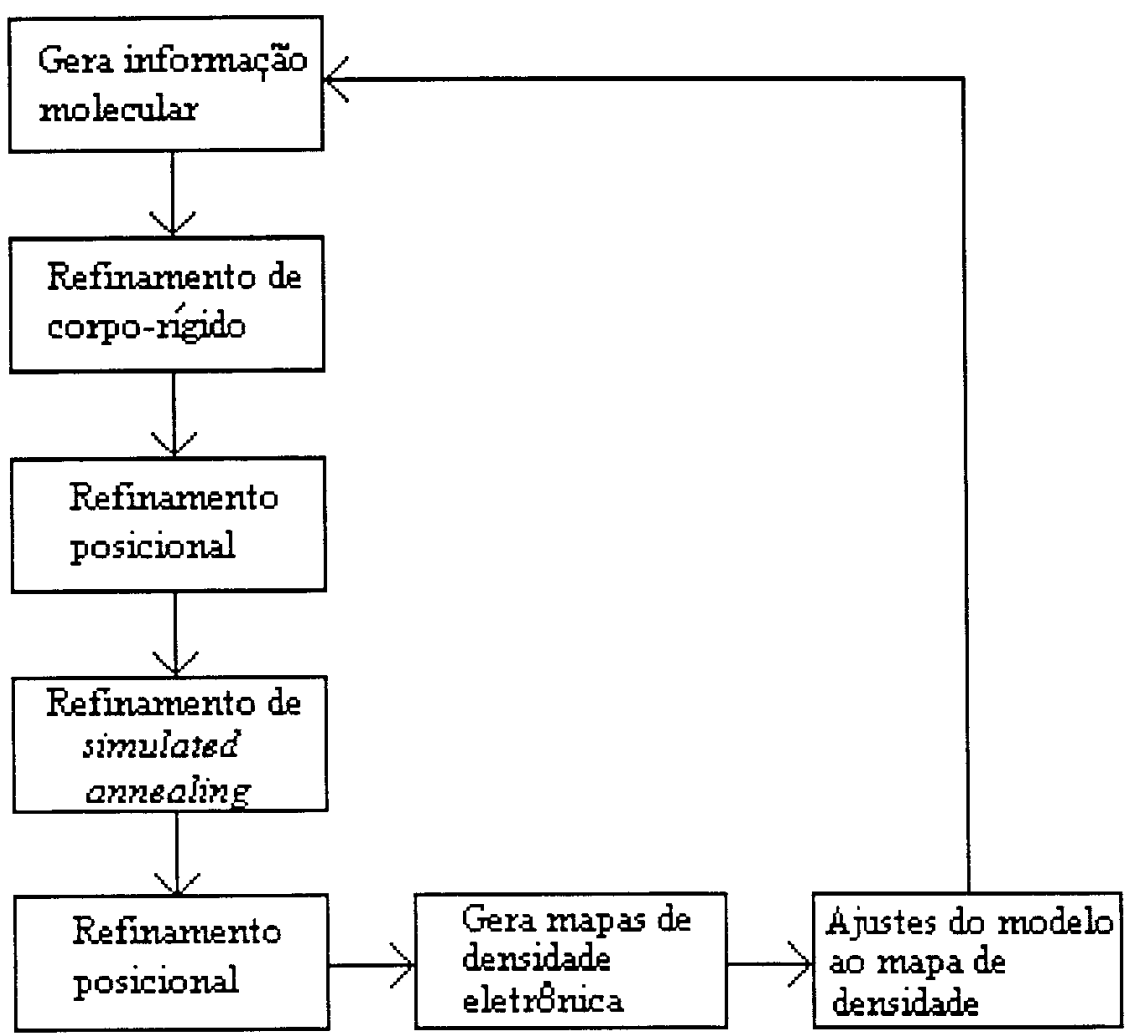

Figura 6.2. Diagrama em blocos do processo de refinamento usando o programa X-PLOR ( Brünger, 1992).

\subsubsection{Refinamento da estrutura do complexo CDK2-DFP ( Azevedo et al., 1996).}

Após o modelo inicial ter sido encontrado na procura translacional este foi submetido a 40 ciclos de refinamento de corpo-rígido que fizeram com que o $\mathrm{R}_{\text {factor }}$ caísse de $33,4 \%$ para $31,2 \%$, para dados entre 8,0 e $3,0 \AA$, o $R_{\text {free }}$ caiu de $35,3 \%$ para $33,7 \%$. O próximo passo de refinamento foram 120 ciclos de refinamento posicional, onde o $\mathrm{R}_{\text {factor }}$ caiu para $25,6 \%$ e o $\mathrm{R}_{\text {free }}$ para $31,1 \%$. Usamos estas coordenadas para o refinamento de simulated annealing (Brünger, 1991), com temperatura inicial de $3000 \mathrm{~K}$ e passos de 0,5 fs. Para isto usamos o supercompudador CRAY do Lawrence Berkeley National Laboratory, pois tais rotinas de refinamento tomam grande tempo de CPU em workstations. $\mathrm{O}_{\mathrm{factor}}$ ao final do refinamento era de $23,2 \%$ e $\mathrm{R}_{\text {free }}$ de $30,3 \%$, para dados de 8,0 a 2,33 $\AA$. Mapas de densidade eletrônica $F_{\text {obs }}-F_{\text {calc }}$ foram gerados e mostraram uma densidade eletrônica no bolsão de ligação de ATP. Construímos um modelo para o inibidor usando o programa INSIGHT II (os arquivos de topologia e parâmetros químicos 
do modelo do inibidor estão no apêndice 2), e ajustamos este modelo à densidade eletrônica usando o programa FRODO ( Jones, 1978). A figura 6.3. mostra o inibidor ajustado ao mapa, com algumas das cadeias laterais próximas do inibidor. O refinamento continuou com ciclos alternados de refinamento posicional e ajuste das cadeias laterais da CDK2. As moléculas de água foram posicionadas em picos do mapa de diferença de densidade eletrônica maiores que $3 \sigma(\rho)$. O modelo final tem um $\mathrm{R}_{\text {factor }}$ de $20,3 \%$ e um $\mathrm{R}_{\text {free }}$ de $28,8 \%$, com boa estereoquímica (tabela 6.2).

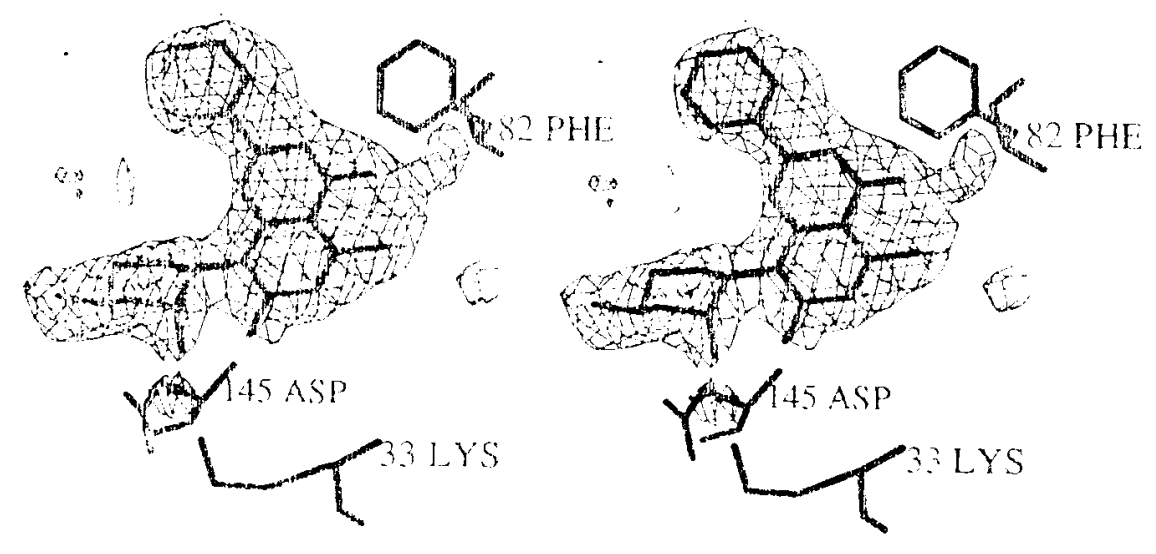

Figura 6.3. Mapa de densidade eletrônica para CDK2-DFP. Vista estereoscópica da densidade eletrônica para o inibidor Descloro-flavopiridol no mapa de diferença de densidade eletrônica $\left(\mathrm{F}_{\mathrm{o}}-\mathrm{F}_{\mathrm{c}}\right)$ após refinamento de simulated annealing. Os mapas estão contornados em 2,5 $\sigma(\rho)$ e mostrados usando o programa O (Jones et al., 1991).

Os desvios entre o modelo refinado e a geometria ideal para ângulos e distâncias de ligação foram calculados usando o programa X-PLOR (Brünger, 1992). Superposições entre proteinas baseadas nos carbonos $\alpha$ foram feitas com o programa LSQKAB do pacote CCP4 (Collaborative Computational Project No. 4). Ligações de hidrogênio e contatos de van der Waals foram conferidos com o programa 
CONTACSYM ( Sheriff et al., 1987). O limite máximo para ligações de hidrogênio e pontes salinas foi de $3,4 \AA$, e de $4,11 \AA$ para os contatos de van der Waals, dependendo do tipo de átomo, e usando-se os raios de van der Waals padrões. A acessibilidade do solvente para resíduos individuais foi calculada usando-se o programa MS ( Connolly, 1983) com um raio de 1,7 $\AA$ para a sonda de solvente.

\subsubsection{Refinamento da estrutura do complexo CDK2-Roscovitine.}

Para o estudo estrutural do complexo CDK2-Roscovitine foram conseguidos cocristais e cristais por soaking. Como os cristais obtidos por soaking difratavam a mais alta resolução do que os co-cristais utilizamos os primeiros para a coleta de dados de difração de raios $\mathrm{X}$. Os cristais de CDK2-Roscovitine não apresentavam danos por radiação tão forte quanto aquele apresentado pelos cristais de CDK2-DFP, por isso, fez-se a coleta de dados a $4^{\circ} \mathrm{C}$. O refinamento de corpo-rígido das coordenadas da CDK2 nativa sem as moléculas de água contra os dados do complexo CDK2-roscovitine, fez com que o $\mathrm{R}_{\text {factor }}$ do complexo caísse de $48 \%$ para $26 \%$ e o $\mathrm{R}_{\text {free }}$ fosse de $35 \%$ para $31 \%$ com dados de 8,0 a $3,0 \AA$. O refinamento do modelo prosseguiu com refinamento posicional e refinamento por simulated annealing, fazendo com que o $\mathrm{R}_{\text {factor }}$ caísse de $26 \%$ para $21 \%$ e o $\mathrm{R}_{\text {free }}$ de $31 \%$ para $29 \%$. Neste estágio mapas de diferença de densidade eletrônica $F_{\text {obs }}$ - $\mathrm{F}_{\text {calc }}$ foram calculados. Estes mapas mostraram uma densidade clara para o roscovitine ligado ao bolsão de ligação de ATP do estrutura de CDK2 (figura 6.4). O refinamento seguiu com ciclos alternados de ajuste da estrutura ao mapa $2 \mathrm{~F}_{\text {obs }}-\mathrm{F}_{\text {calc }}$ usando os programas O (Jones et al., 1991) e FRODO ( Jones, 1978). O modelo do inibidor roscovitine foi construído usando-se o programa INSIGHT II (os arquivos de topologia e parâmetros químicos do modelo do inibidor estão no apêndice 3), e ajustado no mapa de densidade eletrônica. As moléculas de água foram posicionadas em picos do mapa de diferença de densidade eletrônica maiores que $3 \sigma(\rho)$. O modelo final tem um $\mathrm{R}_{\text {factor }}$ de $18 \%$ e um $\mathrm{R}_{\text {free }}$ de $27 \%$ com boa estereoquímica. 
Tabela 6.2. Estatística de refinamento das estruturas de CDK2 em complexo com DFP (Decloro-FlavoPiridol) e Roscovitine.

\begin{tabular}{lll}
\hline Complexo & CDK2-DFP & CDK2-Roscovitine \\
Resolução $(\AA)$ & $8,00-2,33$ & $8,00-2,40$ \\
$\mathrm{R}_{\text {fructor }}(\%)$ & 20,3 & 18 \\
$\mathrm{R}_{\text {free }}(\%)$ & 28,8 & 27 \\
Valores de $\mathrm{B}^{*}\left(\AA^{2}\right)$ & & \\
$\quad$ Cadeia principal & 31,0 & 20,6 \\
$\quad$ Cadeias laterais & 33,7 & 24,3 \\
$\quad$ Inibidor & 34,4 & 37,1 \\
$\quad$ Águas & 37,0 & 31,2 \\
Desvios médios observados em relação à & & \\
geometria ideal. & & 0,011 \\
$\quad$ Distâncias de ligação $(\AA)$ & 0,012 & 1,5 \\
Ângulos de ligação $\left({ }^{\circ}\right)$ & 1,7 & 82 \\
Número de moléculas de água & 84 & \\
& & \\
\hline
\end{tabular}

* Valores de B são os valores médios do fator de vibração térmica B (Stout \& Jensen, 1989 p. 189) para átomos diferentes de hidrogênio.

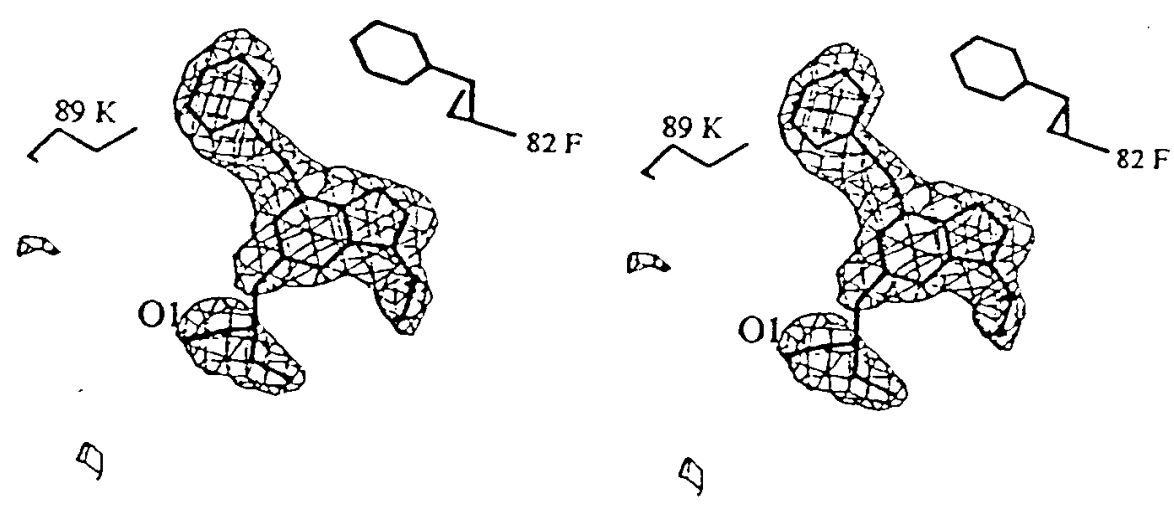

Figura 6.4. Mapa de densidade eletrônica para CDK2-Roscovitine. Vista estereoscópica da densidade eletrônica para o inibidor Roscovitine no mapa de diferença de densidade eletrônica $\left(\mathrm{F}_{\mathrm{o}}-\mathrm{F}_{\mathrm{c}}\right)$ após refinamento de simulated annealing. Os mapas estão contornados em $2,5 \sigma(\rho)$ e mostrados com O ( Jones et al., 1991). 


\subsection{Conformação geral da proteína e mecanismo de ativação.}

A estrutura da CDK2 dos dois complexos binários estudados nesta tese é quase idêntica às estruturas das CDK2s encontradas nas CDK2 nativa e CDK2-ATP (De Bondt et al., 1993), CDK2-Ciclina A ( Jeffrey et al., 1995) e CDK2-Ciclina A- p27 ( Russo et al., 1996). Como observada em várias estruturas de CDK2 a densidade eletrônica é fraca em duas regiões, entre os resíduos 36-47 e os resíduos 150-164. Estas regiões são de alta flexibilidade estrutural e foram omitidas do refinamento das coordenadas do complexos CDK2-DFP (Azevedo et al., 1996) e CDK2-Roscovitine.

A estrutura da CDK2 consiste de dois domínios ( diagrama topológico na figura 6.5). O menor, o N-terminal, consiste de uma folha de cinco fitas- $\beta$ antiparalelas $(\beta 1-\beta 5) \mathrm{e}$ uma única hélice- $\alpha(\alpha 1)$. O domínio maior, o C-terminal, contém um pseudo feixe de quatro hélices $(\alpha 2,3,4,6)$, algumas fitas- $\beta$ pequenas $(\beta 6-\beta 8)$, e duas hélices- $\alpha$ adicionais $(\alpha 5,7)$. O bolsão de ligação de ATP na estrutura da CDK2 ( figuras 6.6a, b) fica entre os dois domínios. $O$ núcleo da estrutura da $\operatorname{CDK} 2$ ( a folha- $\beta$ e o feixe de hélices ) é bem similar àquela da subunidade catalítica da PKA ( Knighton et al., 1991, Zheng et al., 1993), embora estas duas quinases possuam pouca identidade na sequência de amino ácidos ( por volta de $24 \%$ idênticas). Quando as duas quinases são superpostas, aproximadamente $44 \%$ dos átomos $\mathrm{C} \alpha$ na CDK2 estão a menos de $1,5 \AA$ das suas posições na PKA. Os átomos $\mathrm{C} \alpha$ de nove residuos invariantes encontados em todas as quinases ( Hanks \& Quinnm 1991) possuem posições em geral bem similares nas estruturas da CDK2 e PKA, isto corrobora que os núcleos catalíticos de todas quinases de eucariontes compartilham de considerável similaridade estrutural.

A comparação das estruturas da CDK2 em complexo com ATP ( figura 6.6a) com aquela do complexo ternário CDK2-Ciclina A e ATP (figura 6.8) ( Kim et al., 1996) mostra que há cinco diferenças conformacionais significantes para a ativação do complexo CDK2-Ciclina A (figuras 6.7a, b): (1) os dois domínios da CDK2 estão mais abertos no complexo ternário CDK2-Ciclina A-ATP, o que leva o laço-P ( $P$-loop) para próximo do N-terminal; (2) A conformação do trifosfato da molécula de ATP e os resíduos que o cercam são diferentes; (3) uma hélice- $\alpha$ curta ( $\alpha$ L12) da CDK2 se torna fita- $\beta$ quando ocorre a ligação da Ciclina A; (4) O laço-T (T-loop) que contém o resíduo Thr160, que é

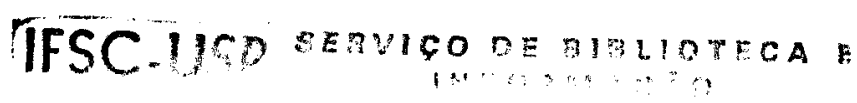


fosforilado para que a CDK2 se torne ativa, se reorienta completamente na estrutura do complexo ternário e (5) o motivo "PSTAIRE" da CDK2, também chamado de hélice de ligação de ciclina, muda sua localização e orientação no complexo ternário. Estas diferenças estão mostradas esquematicamente nas figuras $6.7 \mathrm{a}, \mathrm{b}$. Em resumo, podemos destacar que a ligação da Ciclina A à CDK2 provoca mudanças conformacionais na hélice PSTAIRE da CDK2, que realinha os resíduos do sítio ativo, junto com o movimento do laço-T da CDK2, que remove o bloqueio do bolsão de ligação de ATP. As interações do laço-T da CDK2 com a Ciclina A também expõe a Thr160, o que faz a Thr160 um substrato mais acessivel para a fosfolilação realizada pela CAK.

Não há grandes diferenças entre as orientações dos domínios dos complexos de CDK2 com os inibidores ( DFP e Roscovitine) e CDK2-ATP. Os inibidores se ligam na região entre os dois domínios, onde também se liga a molécula de ATP (figuras 6.9.a, b)

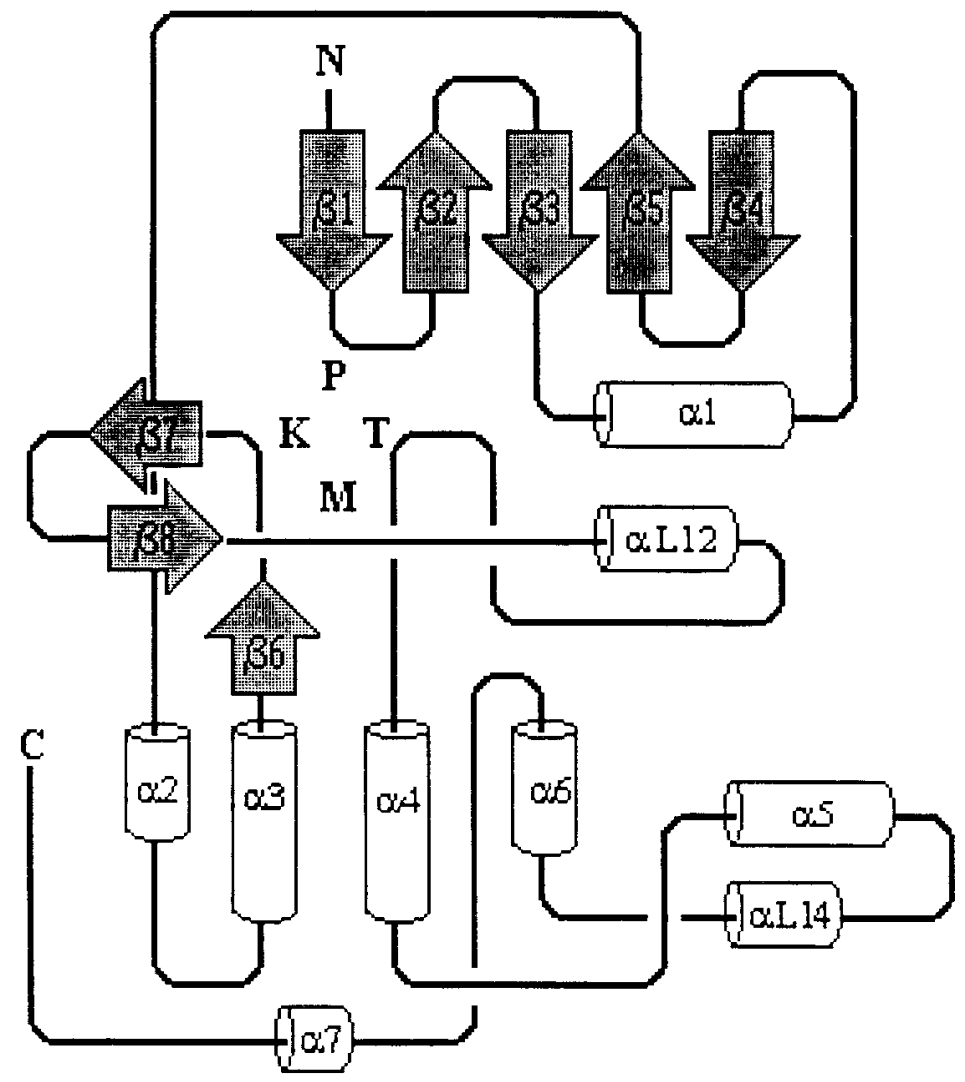

\section{Elementos de estrutura secundária :}

Fita- $\beta$

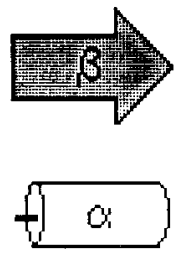

Hélice- $\alpha$

Elemento de ligação (coill)

Figura 6.5. Diagrama topológico dos elementos de estrutura secundária da CDK2. 


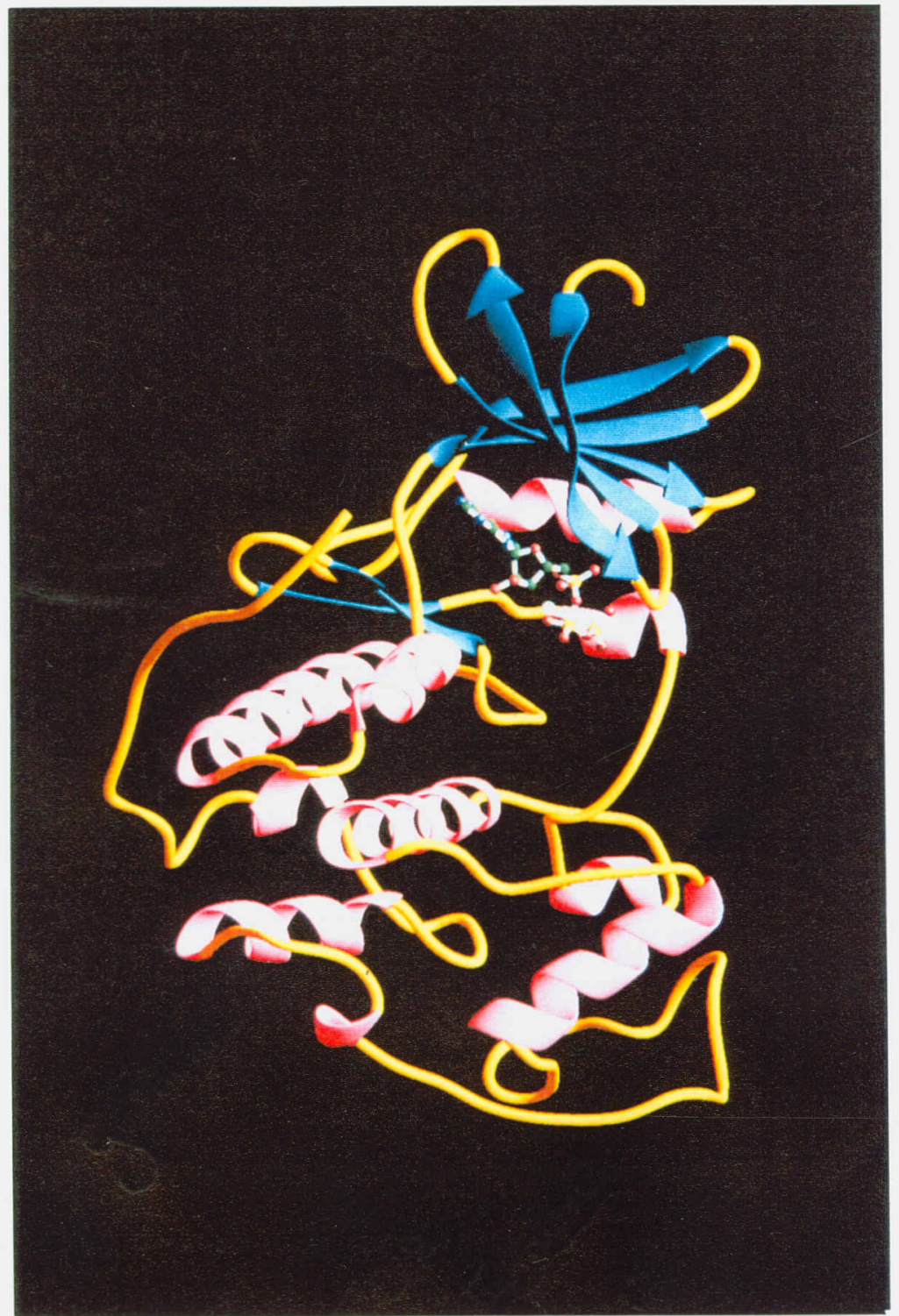

Figura 6.6. Estrutura da CDK2-ATP. a)Estrutura secundária da CDK2 complexada com ATP. A molécula de ATP se liga entre os dois domínios da CDK2. As fitas- $\beta$ são mostradas em azul-claro, as hélices- $\alpha$ em rosa e o restante em amarelo. 


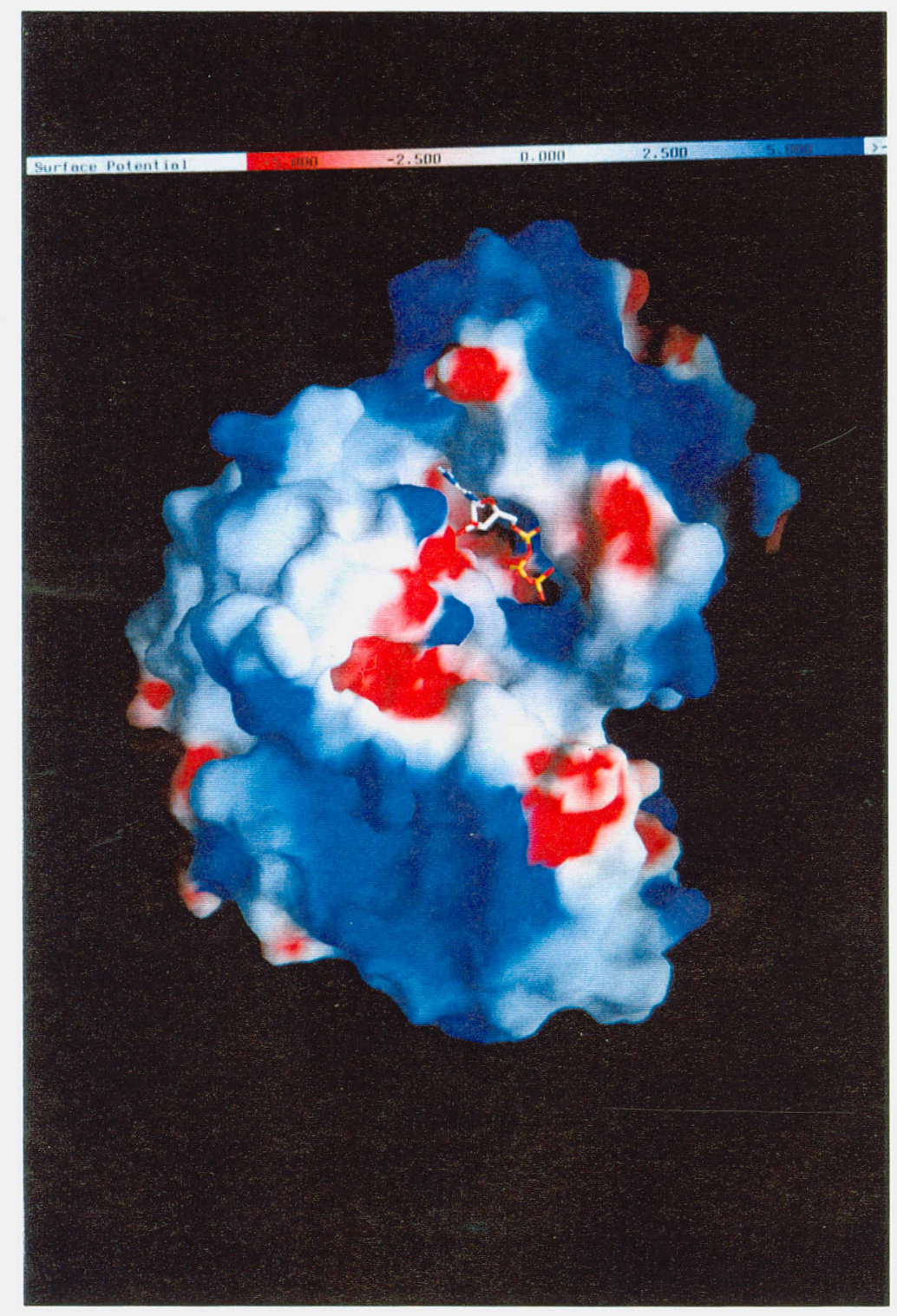

Figura 6.6. (Continuação) b) Superficie de acessibilidade ao solvente da CDK2 as áreas em azul indicam concentração de carga positiva, as áreas vermelhas indicam concetração de carga negativa e as áreas brancas são neutras. O fosfato- $\gamma$ da molécula de ATP se liga numa região de cargas positivas. A orientação da molécula de CDK2 nesta figura é similar àquela da 6.6a. Este desenho foi gerado com o programa GRASP (Nicholls, Sharp \& Honig, 1991). 

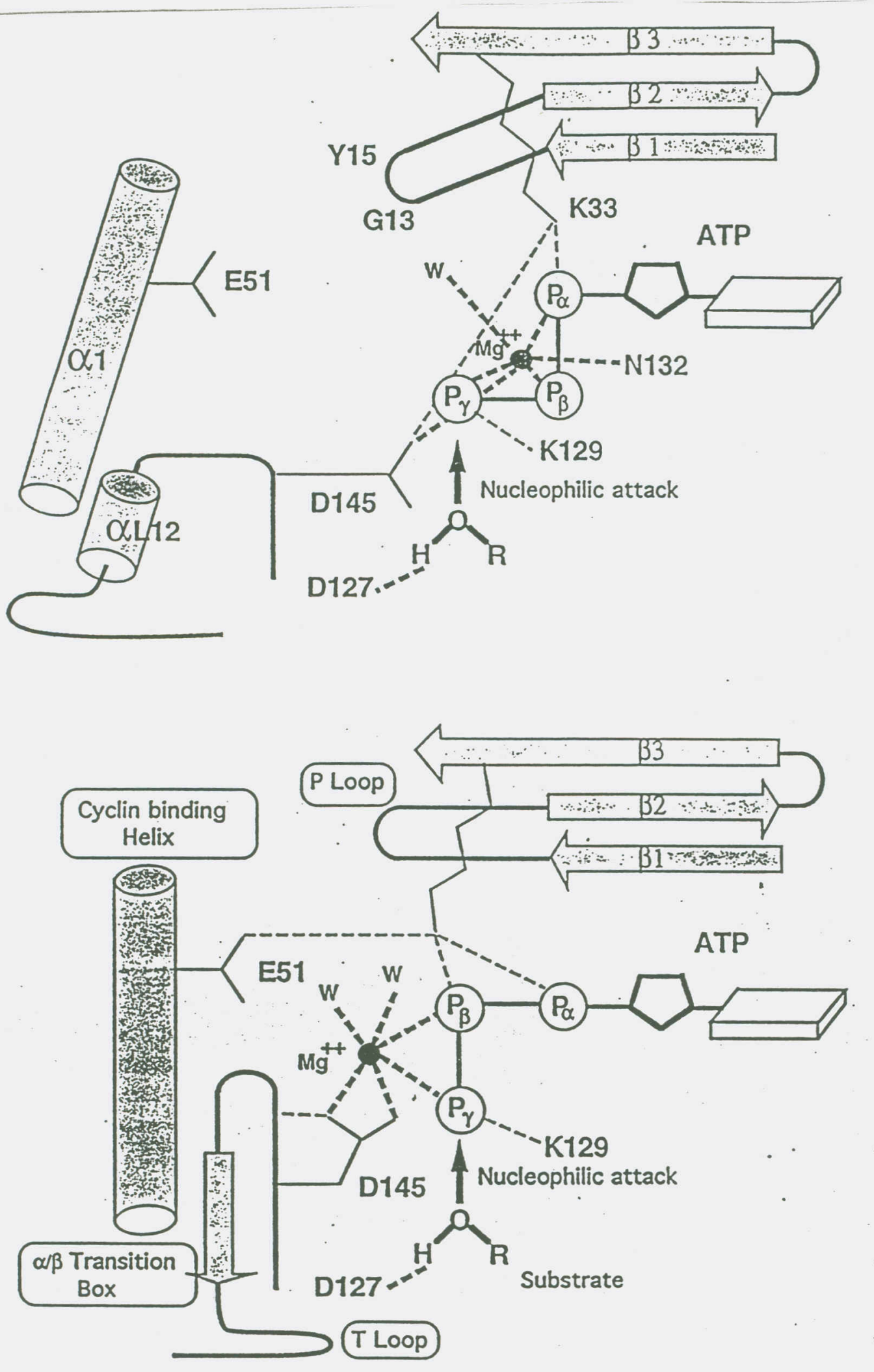

Figura 6.7. Mudanças na estrutura do complexo CDK2-Ciclina A. Desenho esquemático das cinco regiões que possuem diferenças conformacionais entre as estruturas (a) do complexo binário CDK2-ATP e (b) do complexo ternário CDK2-ATP-Ciclina A 


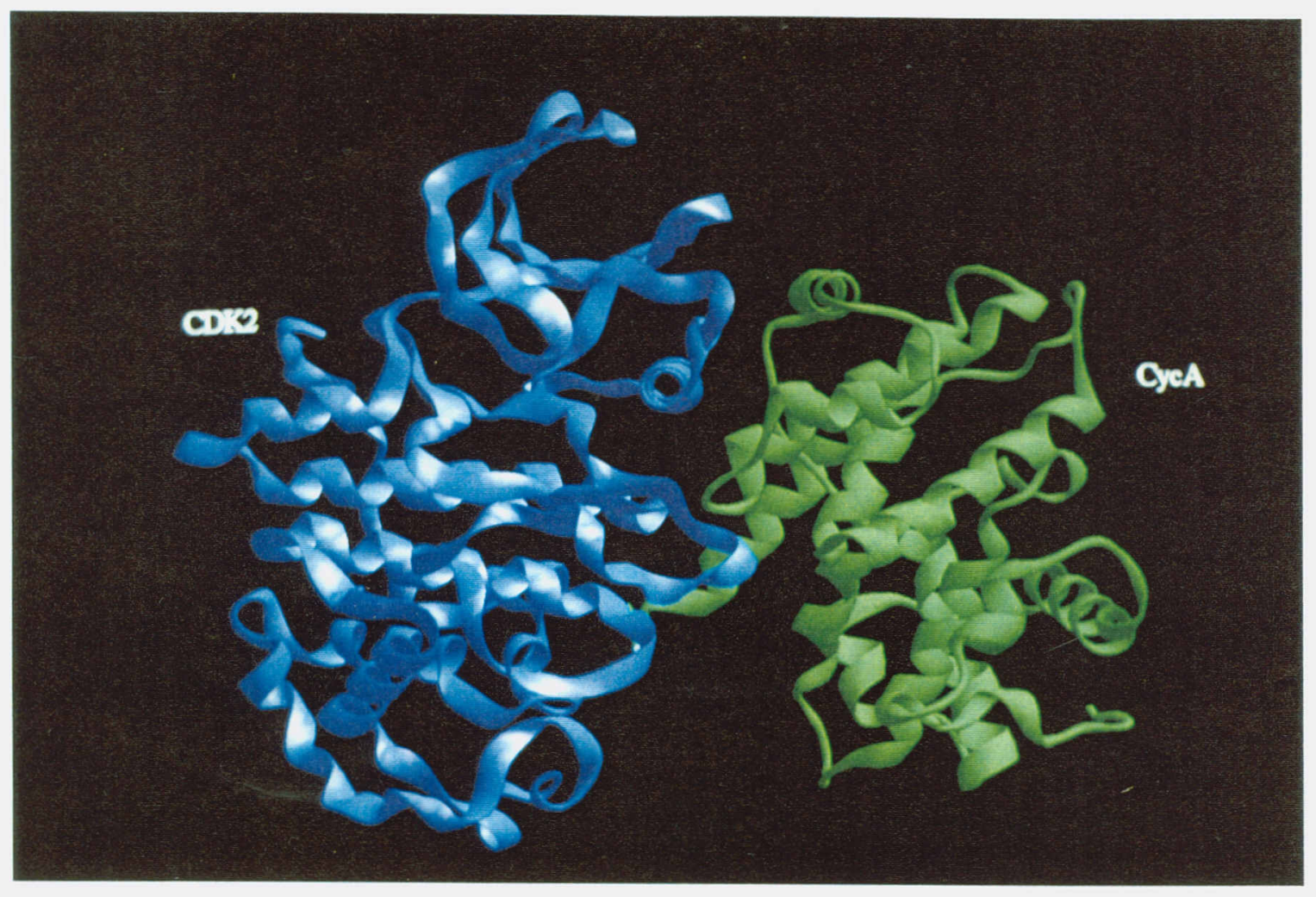

Figura 6.8. Diagrama esquemático do complexo CDK2-Ciclina A. A Ciclina A está em verde e a CDK2 em azul.

\subsection{Conformação do inibidor DFP e do bolsão de ligação (Azevedo et al., 1996).}

A densidade eletrônica para a maioria do átomos do inibidor DFP é clara e forte (figura 6.4 ) O DFP se liga no bolsão de ligação de ATP da CDK2, com o anel benzopiran do DFP ocupando aproximadamente a mesma região do anel de adenina da molécula de ATP na estrutura do complexo CDK2-ATP (figura 6.10a). Os dois sistemas de anéis se superpõem no mesmo plano, mas o anel benzopiran no DFP está rotacionado aproximadamente $60^{\circ}$ com relação à adenina da molécula de ATP (figura 6.10b). Nesta orientação, os oxigênios $\mathrm{O} 5$ e $\mathrm{O} 4$ da molécula de DFP estão próximos às posições do amino grupo N6 e do átomo N1 na adenina, respectivamente. No complexo CDK2-DFP o anel fenil da molécula de DFP está apontando para fora do bolsão de ligação de ATP e ocupa uma região não ocupada por nenhuma das partes da molécula de ATP na estrutura CDK2-ATP. O anel piperidinil do DFP ocupa o bolsão do fosfato- $\alpha$ e lhe foi atribuída a 
conformação em cadeira, contudo, a conformação de bote não pode ser completamente descartada.

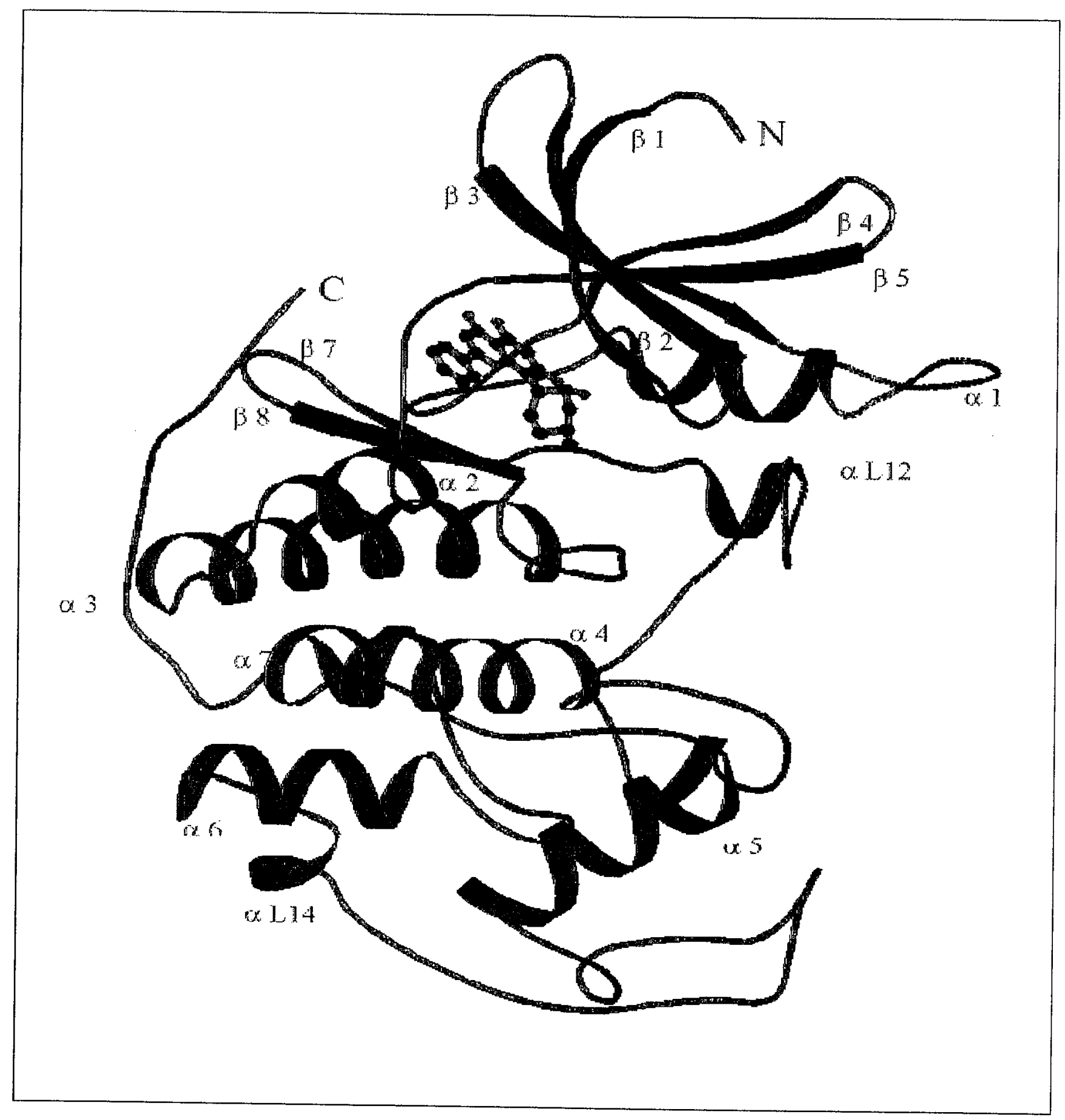

Figura 6.9.a) Diagrama esquemático da CDK2 com o inibidor Descloro-flavopiridol (DFP). 


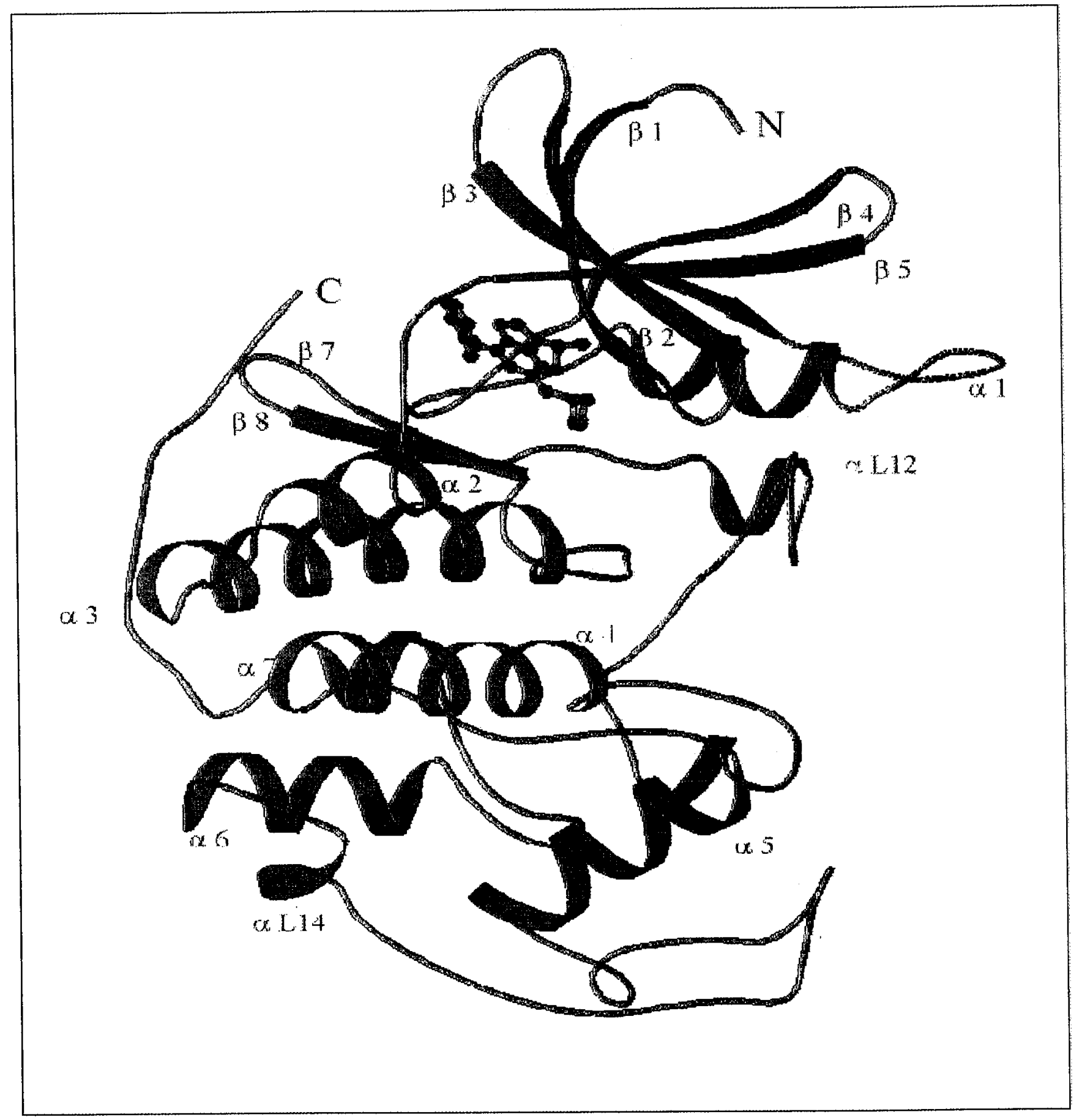

Figura 6.9.b) Diagrama esquemático da CDK2 com o inibidor Roscovitine. 
a)

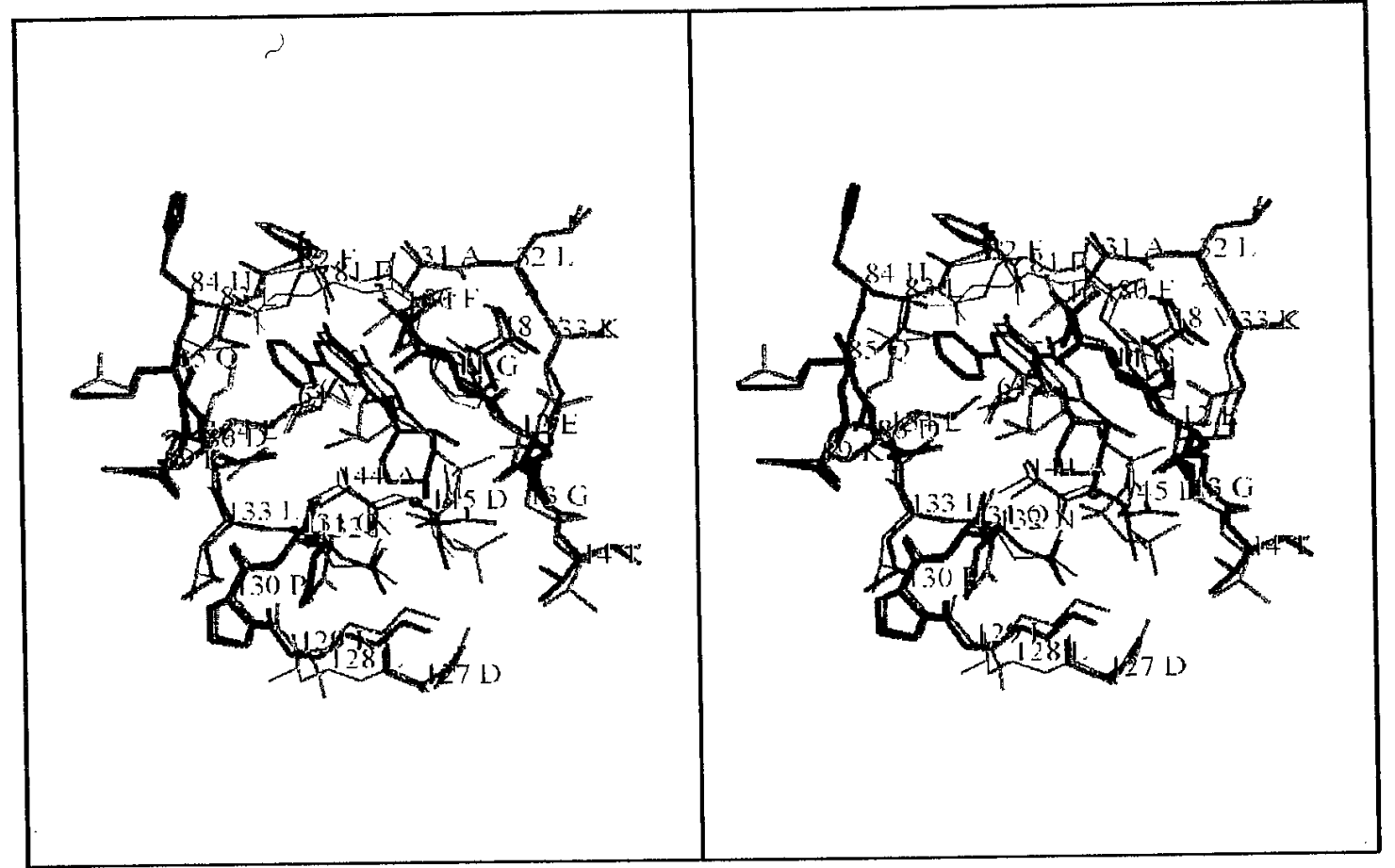

b)
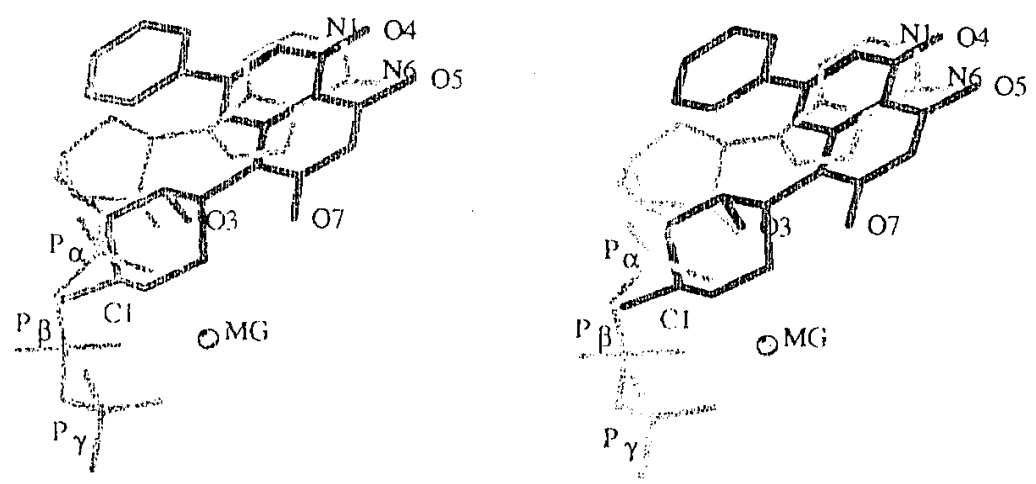

Figura 6.10. a) Superposição dos bolsões de ligação dos complexos CDK2-ATP (verde) e CDK2-DFP (azul), b) as moléculas de ATP (cinza) e DFP (preto) após a superposição dos carbonos- $\alpha$ da CDK2 dos dois complexos ( CDK2-ATP e CDK2-DFP). 
Na estrutura do complexo CDK2-ATP ( De Bondt et al., 1993), as interações da CDK2 com a molécula de ATP são caracterizadas predominantemente por interações hidrofóbicas e de van der Waals entre a proteína e a base adenina, e interações iônicas, ligações de hidrogênio e interações de van der Waals com a ribose e o trifostato da molécula de ATP ( figura 6.11a). No total há 26, 15 e 38 contatos entre CDK2 e a base adenina, ribose e fosfatos, respectivamente. $O$ anel de adenina está envolvido por um bolsão hidrofóbico formado pelo resíduos Ile10, Ala31, Val64, Phe80, Phe82 e Leu134 (figura 6.11a) e forma duas ligações de hidrogênio entre o nitrogênio N6 da adenina e o oxigênio do carbonil do Glu81, e entre o nitrogênio N1 e o nitrogênio da cadeia principal da Leu83. As mesmas ligações de hidrogênio são mantidas na estrutura da quinase dependente de AMP cíclica (PKA) (Zheng et al., 1993; Bossemeyer et al., 1993), e a ligação ao átomo N6 mostrou-se importante para a afinidade de ligação do ATP à quinase PKA (Hoppe et al., 1978).

$\mathrm{Na}$ estrutura do complexo CDK2-DFP, a molécula do inibidor é bem hidrofóbica, consequentemente a interação com CDK2 é caracterizada principalmente por interações hidrofóbicas e de van der Waals, com os mesmos resíduos hidrofóbicos da enzima que formam o bolsão para a base adenina na estrutura do complexo CDK2-ATP. Entretanto, há mais contatos entre a enzima e o anel benzopiran do DFP (34 contatos) que entre a enzima e a adenina da molécula de ATP ( 26 contatos) (figuras 6.11 a e b). Nós observamos 5 ligações de hidrogênio entre o DFP e a enzima, envolvendo os resíduos Lys33, Glu81, Leu83 e Asp145 e estes resíduos também formam ligações de hidrogênio no complexo CDK2-ATP. Há ainda 7 contatos de van der Waals com o anel piperidinil e 10 contatos com o anel fenil, o que eleva o número total de contatos entre a molécula de DFP e a enzima para 56. Muitos destes contatos entre DFP e CDK2 são feitos por somente três resíduos, Ile10, Leu83 e Leu134, que formam um total de 24 contatos com a molécula de DFP ( figura $6.11 \mathrm{~b}$ ), o que correponde a $43 \%$ dos contatos observados. 


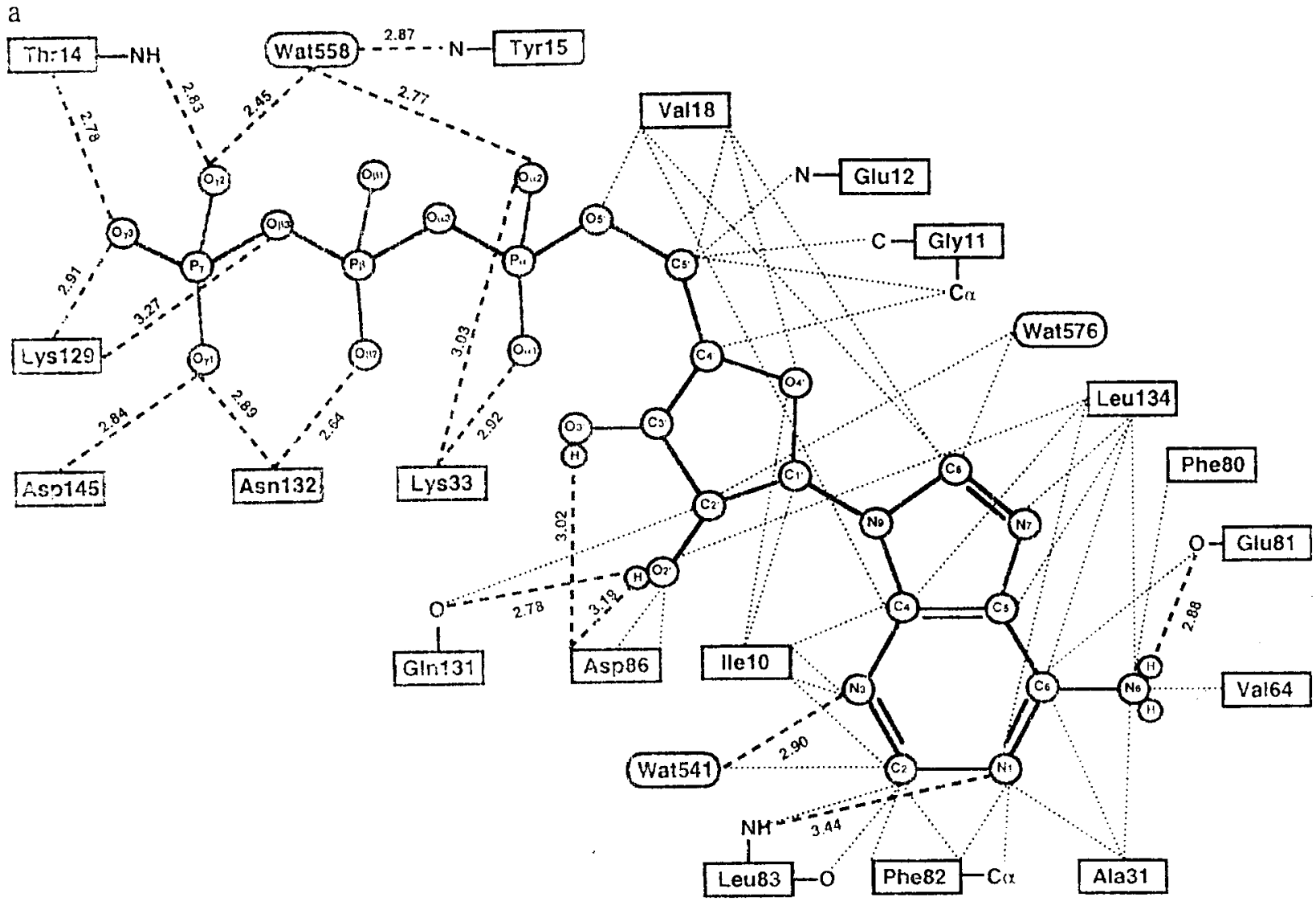

b

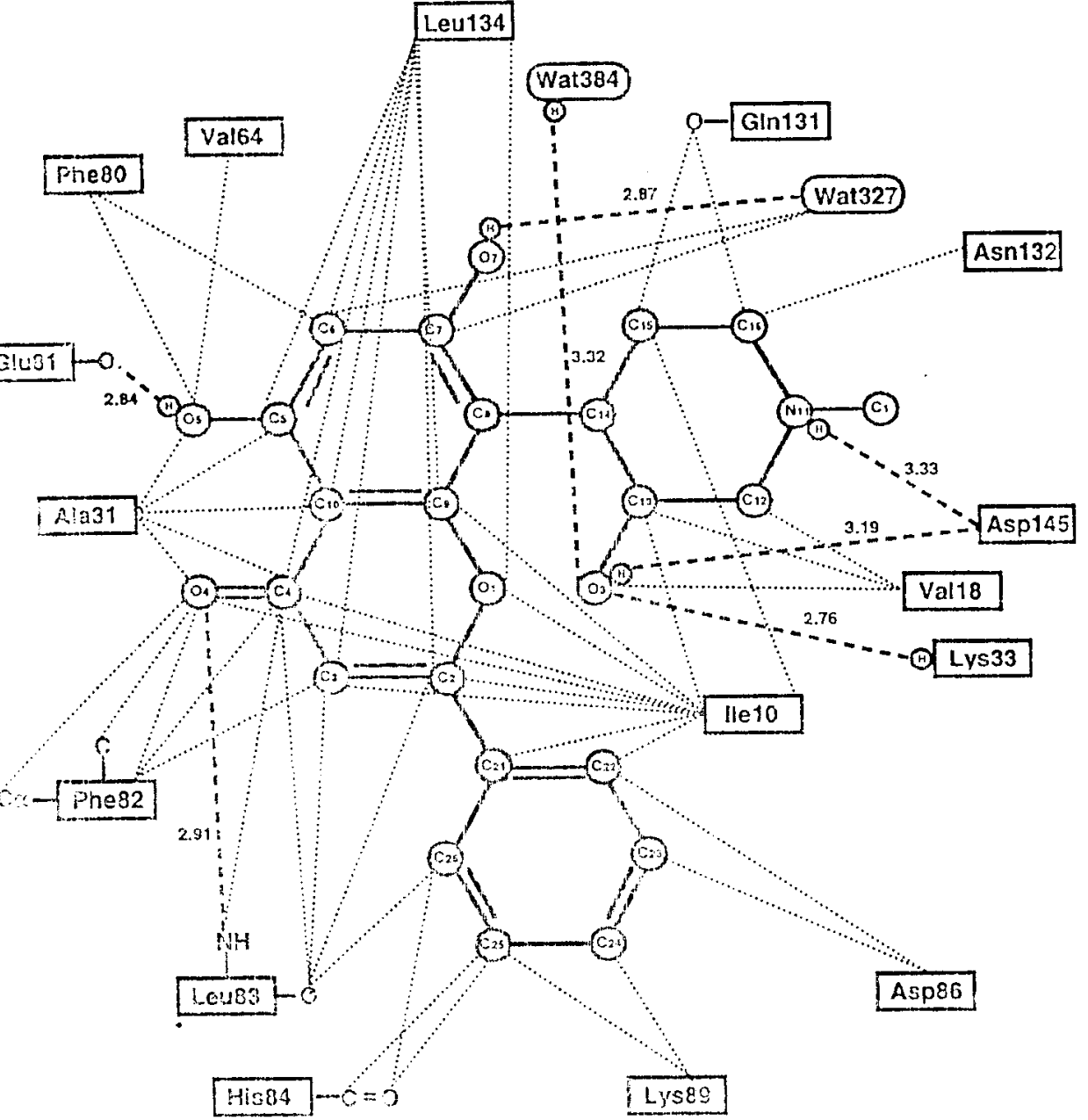

Figura

6.11.

Diagrama esquemático mostrando as interações de CDK2 com ATP (a) e DFP (b). Os contatos com as cadeias laterais da proteína são indicados por linhas conectando à respectiva caixa do residuo enquanto interações com átomos da cadeia principal são mostrados como linhas ligadas ao átomo especifico da cadeia principal. Contatos de van der Waals são indicados por linhas pontilhadas, e ligaçōes de hidrogênio por linhas tracejadas. Para o inibidor todos os contatos são mostrados enquanto para a molécula de ATP os contatos de van der Waals com os fosfatos foram omitidos para maior clareza da figura. As diatància indicadas estão em A. 


\subsection{Conformação do inibidor Roscovitine no bolsão de ligação.}

A densidade eletrônica para todos os átomos do inibidor Roscovitine é clara e forte (figura 6.4). A molécula de Roscovitine se liga ao bolsão de ligação de ATP, com o anel de adenina do Roscovitine ocupando aproximadamente a mesma região ocupada pelo anel de adenina da molécula de ATP. Os dois sistemas de anéis se superpõem aproximadamente no mesmo plano. Entretanto, o anel de adenina no complexo CDK2Roscovitine tem uma conformação diferente daquela da molécula de ATP com relação à proteína (figura 6.12). Nesta orientação, o átomo N7 da molécula de Roscovitine está próxima à posição do átomos $\mathrm{N} 1$ da adenina do ATP. $\mathrm{O}$ anel fenil da molécula de roscovitine aponta para fora do bolsão de ligação e ocupa uma região não ocupada pela molécula de ATP na estrutura de CDK2-ATP. Todas as interações atômicas entre CDK2 e roscovitine estão mostrada na figura 6.13, conforme gerado pelo programa LIGPLOT ( Wallace et al., 1995). São observadas três ligações de hidrogênio, sendo duas com a cadeia lateral do resíduo Leu83, no total temos 53 contatos entre o inibidor e a enzima.

\subsection{Complementaridade geométrica.}

A especificidade e a afinidade entre uma proteína e o seu ligante depende de ligações de hidrogênio direcionais e interações iônicas, e também de complementaridade de formas das superficies de acessibilidade ao solvente do ligante e da proteína ( Janin \& Chothia, 1990, Wilson \& Stanfield, 1993). A complementaridade de forma é melhor descrita como superficies de acessibilidade ao solvente que se contatam na estrutura proteína-ligante. Se a complementaridade é boa, o tamanho das superficies de acessibilidade da proteína e do seu ligante devem ser próximas. No complexo CDK2-ATP a superficie de acessibilidade da molécula de ATP $\left(352 \AA^{2}\right)$ e da CDK2 (435 $\left.\AA^{2}\right)$ mostram um bom ajuste. A molécula de ATP está quase totalmente inacessivel ao solvente (figura 6.6.b) e a sua superfície de acessibilidade é de $80 \%$ da superficie de acessibilidade da CDK2. Os valores correpondentes para o complexo CDK2-DFP são $301 \AA^{2}$ e $399 \AA^{2}$, para o DFP e CDK2, respectivamente. A superficie de acessibilidade do DFP é $75 \%$ da superficie de acessibilidade da CDK2. Para o complexo CDK2-Roscovitine, temos que a superficie de acessibilidade do roscovitine é de $326 \AA^{2}$ e a superficie de acessibilidade da 
CDK2 correspondente é de $419 \AA^{2}$, ou seja, a superficie de acessibilidade do inibidor Roscovitine é de $78 \%$ a superficie de acessibilidade da CDK2 presente no complexo CDK2-Roscovitine (figura 6.14).

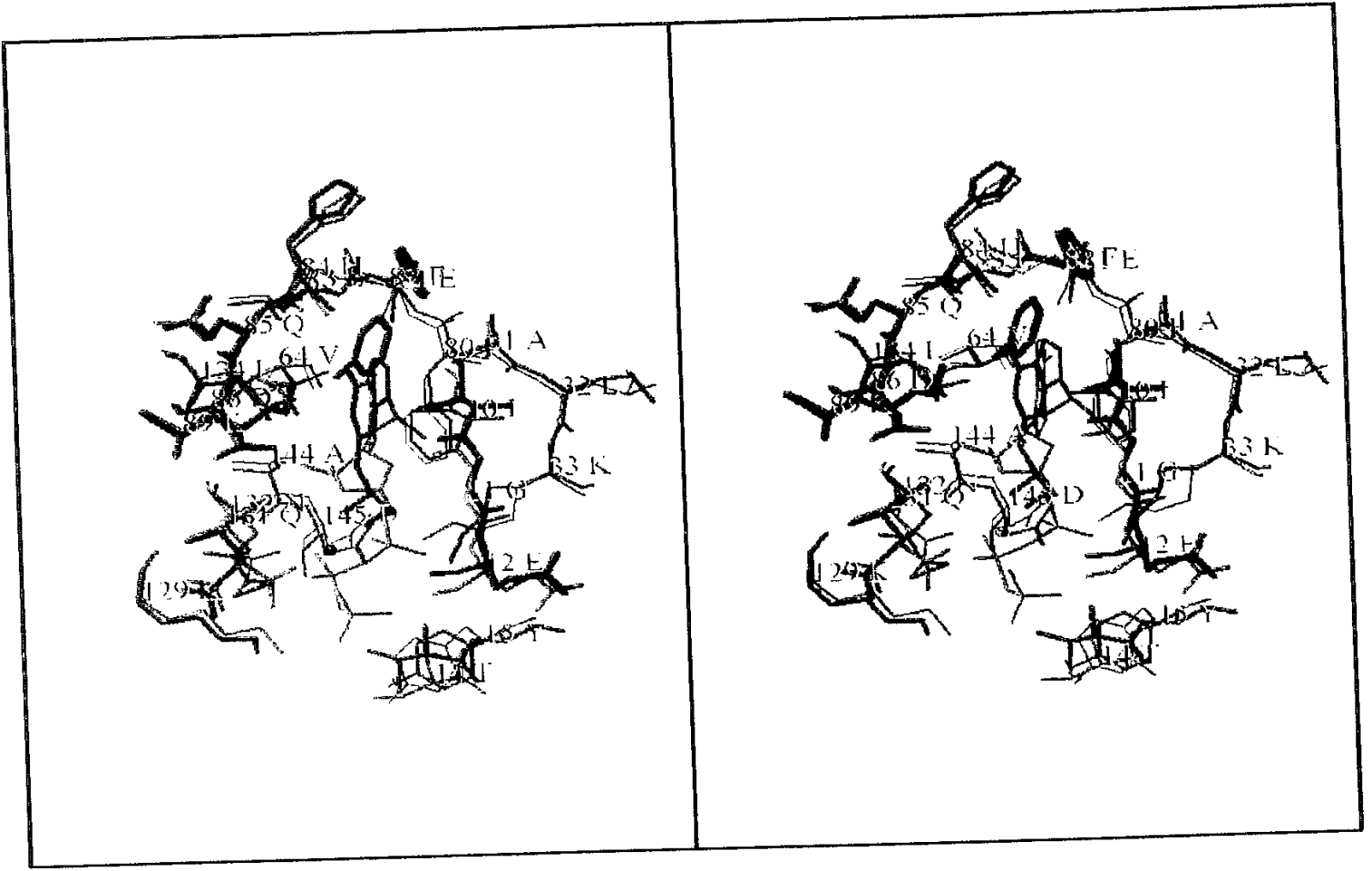

Figura 6.12. Superposição do bolso de ligação de ATP das estruturas dos complexos CDK2-ATP (verde) e CDK2-Roscovitine (azul). 


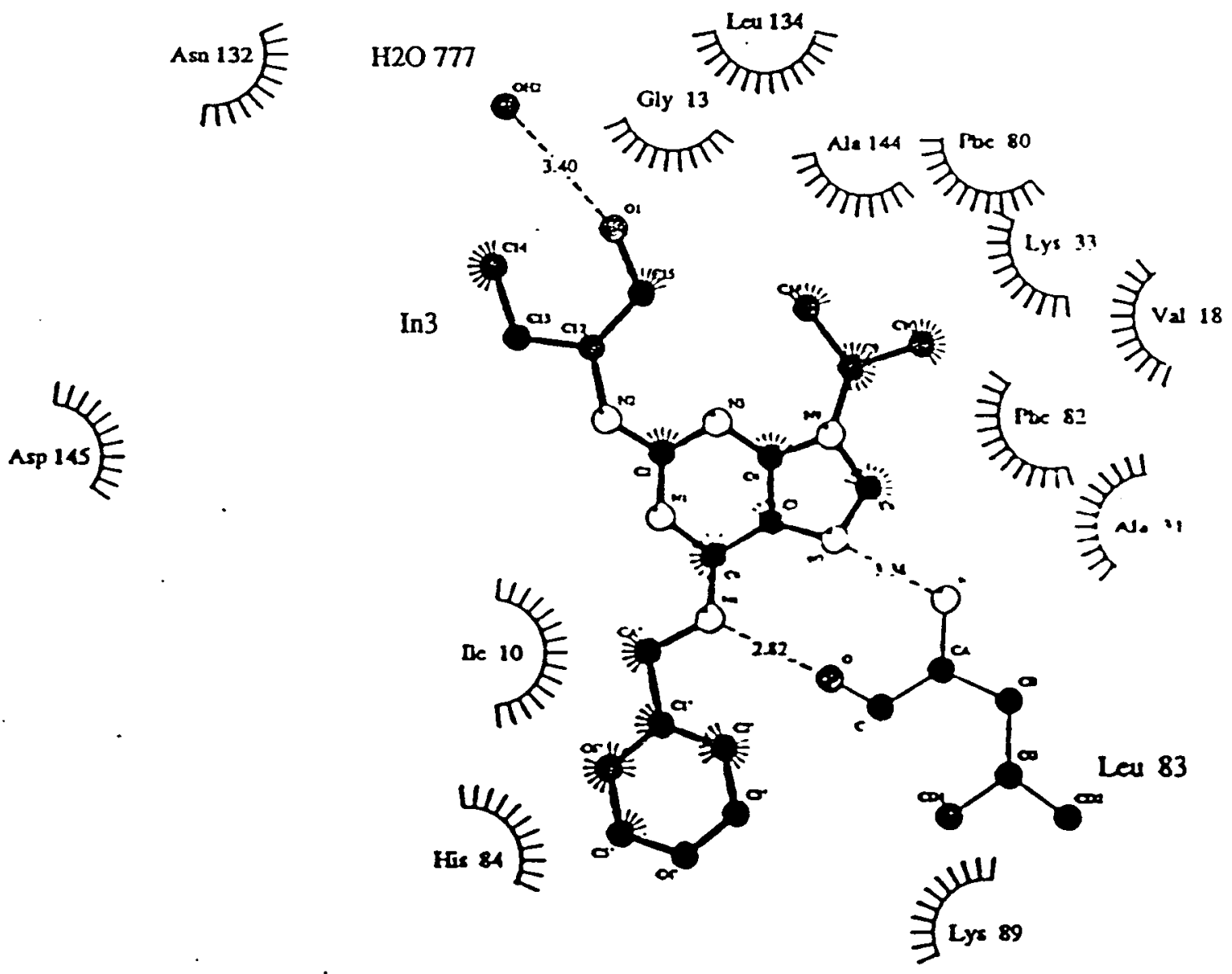

Key

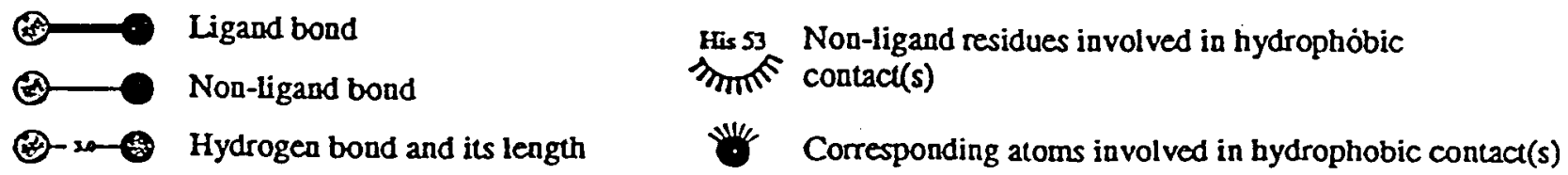

Figura 6.13. Contatos entre a molécula de Roscovitine e a enzima presentes no complexo CDK2-Roscovitine. 


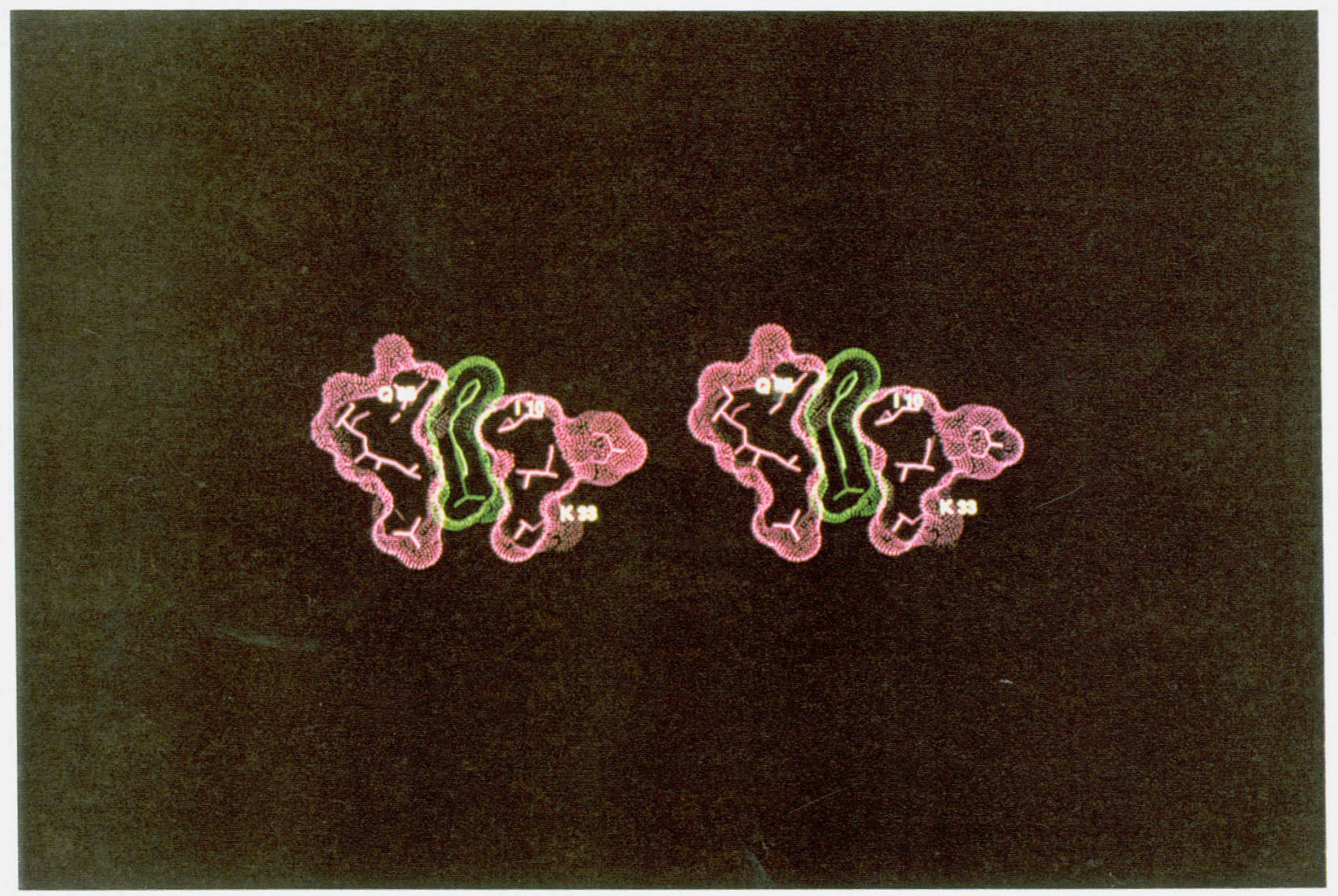

Figura 6.14. Visão estereográfica da superfície de acessibilidade ao solvente do complexo CDK2-Roscovitine. A superficie de acessibilidade ao solvente para o Roscovitine está desenhada em verde e para enzima em rosa. Para maior clareza da figura, só uma pequena faixa dos resíduos de CDK2 que contatam a molécula de Roscovitine são mostrados. Na figura podemos ver a boa complementaridade entre as duas superfícies, a do ligante e a da enzima. Vemos também que o anel fenil da molécula de Roscovitine está só parcialmente inserido na enzima. O desenho foi feito com o programa INSIGHT II. 


\section{CAPÍTULO 7 \\ CONCLUSÃO.}

\subsection{Introdução.}

A resolução da estrutura dos complexos binários da CDK2 humana com dois inibidores, o Descloro-flavopiridol (DFP) e o Roscivitine, forneceram informações para o entendimento a nível atômico do processo de inibição de CDK2 por estes dois inibidores e forneceram as bases para desenho de drogas mais específicas. A informação estrutural para estes dois complexos foi também importante para a comparação com outras estruturas de CDK2 com outros ligantes, que revelaram diversos aspectos comuns entre os diferentes ligantes. Até o momento foram determinadas as estruturas de CDK2 humana com cinco ligantes diferentes, incluindo-se os dois estudados nesta tese. Os outros três são, ATP ( De Bondt et al., 1993) e Olomoucime e Isopenteniladenina (Schulze-Gahmen et al., 1995) e mais recentemente a estrutura da CDK2-Ciclina A foi determinada com o inibidor de CDKs, p27, ligado ao complexo ( Russo et al., 1996) Temos ainda que, a metodologia não-convencional para a determinação da estrutura do complexo CDK2DFP, fica como modelo de procedimento para coleta de dados e determinação de estrutura a ser usado para problemas similares no estudo de outros complexos enzimaligante.

\subsection{Interação CDK2 e DFP.}

Um dos aspectos mais interessantes da estrutura do complexo binário CDK2-DFP é a posição ocupada pelo anel fenil da molécula de DFP, que está apontando para fora do bolsão de ligação de ATP (figuras 7.1. a e b). Esta região não é ocupada por nenhuma das partes da molécula de ATP na estrutura do complexo CDK2-ATP. O anel fenil contribui com dez contatos de van der Waals com a enzima. Os principais resíduos de contato são Leu83, His84 e Asp86. A posição do anel fenil da molécula de DFP é também responsável pela novo posicionamento da cadeia lateral do resíduo Lys89, que é afastado do bolsão de ligação de ATP na estrutura do complexo CDK2-DFP. 
A molécula de Flavopiridol (figura 5.1), que está correntemente em fase I de testes clínicos no National Cancer Institute, USA, possue um clorofenil no lugar do fenil da molécula de DFP. Esta modificação aumenta a inibição da CDK2 por um fator de 6 (Losiewicz et al., 1995). Este aumento é provavelmente devido aos novos contatos com os resíduos Leu10, Phe82 e Leu83 que a inserção de um átomo de cloro traz, que elevam o número total de contatos entre inibidor e enzima para 61. A observação que quando o grupo fenil da molécula de DFP é substituído por grupos menores, como etil ( inibidor L857991, figura 5.1) e propil ( inibidor L858037, figura 5.1), o poder de inibição cai por um fator de 6 ( Losiewicz et al., 1995), pode também ser entendido a partir da estrutura do complexo CDK2-DFP, visto que, tais grupos menores possuem um número menor de contatos com a enzima, do que aquele observado com inibidores que possuem o anel fenil ou clorofenil, DFP e Flavopiridol, respectivamente.

A atividade das quinases CDC2 e CDK2 são inibidas potentemente pelo inibidor flavopiridol ( $\mathrm{IC}_{50}=0,40 \mu \mathrm{M}$ ), onde $\mathrm{IC}_{50}$ é a quantidade de inibidor que deve ser adicionada à enzima para que sua atividade enzimática caia $50 \%$, no caso das quinases CDK2 e CDC2 os ensaios de atividade são realizados contra Histona H1 (Meijer et al., 1991; Veseley et al., 1994). Em contraste, o inibidor Flavopiridol não inibe de forma tão potente outras quinases, tal como PKA ( $\mathrm{IC}_{50}=145 \mu \mathrm{M}$ ) ( Losiewicz et al., 1994). Isto pode ser entendido por meio da comparação dos resíduos que fazem contato com a molécula de DFP na estrutura do complexo CDK2-DFP com resíduos equivalentes nas outras quinases. As maiores diferenças entre CDK2, CDC2 e PKA ocorrem nos resíduos que fazem contato com o anel fenil do inibidor DFP ( Ile10, Leu83, His84, Asp86 e Lys89). Na CDC2, que é inibida potentemente por Flavopiridol, estes resíduos são quase que totalmente conservados como ( Ile10, Leu83, Ser84, Asp86 e Lys89). Em contraste, na PKA, que não é potentemente inibida, nenhum residuo é conservado. Nós usamos o esquema de numeração das seqüências de amino-ácidos mostrados na referência De Bondt, H. et al., 1993 para as seqüências de CDK2 e CDC2, e a numeração adotada para a seqüência de PKA foi tirada da referência Serota \& Radzio-Andzelm, 1994. 


\subsection{Interação CDK2 e Roscovitine.}

A orientação do anel de purina da molécula de Roscovitine é similar à orientação do anel de purina do inibidor Olomoucine do complexo CDK2-Olomoucine ( SchulzeGahmen et al., 1995). Esta orientação é completamente diferente da orientação do anel de purina da molécula de ATP no complexo CDK2-ATP ( De Bondt, H. et al., 1993).

$\mathrm{O}$ anel fenil da molécula de Roscovitine, como observado para o anel fenil da molécula de DFP, ocupa uma região não ocupada por nenhuma parte da moléculade ATP no complexo CDK2-ATP, este anel fenil da molécula de Roscovitine está apontando para fora do bolsão de ligação de ATP e faz vinte contatos com a enzima, sendo que os principais resíduos de contato são os Ile10, Phe82 e His84, como observado na estrutura do complexo CDK2-Olomoucine ( Schulze-Gahmen, U. et al., 1995).

\subsection{Comparações entre os cinco ligantes de CDK2.}

Comparando-se as superficies de acessibilidade ao solvente como calculada com o programa MS (Connolly, 1983) para os cinco ligantes de CDK2 dos quais se possue informação estrutural ( figura 7.3), vemos que, os inibidores de CDK2 mais potentes, Roscovitine, DFP e Olomoucine, possuem uma alta complementaridade entre suas superficies de acessibilidade ao solvente, e uma baixa complementaridade para o inibidor menos potente ( IPA) ( tabela 7.1). Temos também que a comparação do número de contatos também concorda com o $\mathrm{IC}_{50}$, ou seja, inibidores potentes ( baixos $\mathrm{IC}_{50}$ ) possuem maior número de contatos com a enzima, enquanto o menos específico IPA (mais alto $\mathrm{IC}_{50}$ ), possue um número menor de contatos com a enzima ( tabela 7.1). 
Tabela 7.1. Superficies de acessibilidade ao solvente para os cinco inibidores dos quais se possuem informação estrutural.

\begin{tabular}{|c|c|c|c|c|c|}
\hline Ligante da CDK2 & $\begin{array}{l}\text { Área } \quad \text { de } \\
\text { acessibilidade ao } \\
\text { solvente na } \mathrm{CDK} 2 \\
\left(\AA^{2}\right) .\end{array}$ & $\begin{array}{l}\text { Área de } \\
\text { acessibilidade ao } \\
\text { solvente no inibidor } \\
\left(\AA^{2}\right) \text {. }\end{array}$ & $\begin{array}{l}\text { Complementaridade } \\
(\%) .\end{array}$ & $\begin{array}{l}\text { Número de contatos } \\
\text { entre } \mathrm{CDK} 2 \text { e } \\
\text { ligante }\end{array}$ & $\mathrm{IC}_{\mathbf{s o}}(\mu \mathrm{M})$ \\
\hline ATP & 435 & 352 & 81 & 79 & - \\
\hline Roscovitine & 419 & 326 & 78 & 55 & 0,4 \\
\hline DFP & 399 & 301 & 75 & 56 & 1,7 \\
\hline Olomoucine & 360 & 261 & 73 & 57 & 7,0 \\
\hline $\begin{array}{l}\text { Isopenteniladenina } \\
\text { (IPA) }\end{array}$ & 290 & 203 & 70 & 36 & 50 \\
\hline
\end{tabular}

${ }^{\circ}$ Complementaridade $=100 \times$ (superficie de acessibilidade ao solvente no ligante)/(superficie de acessibilidade ao solvente na enzima).

Um fator comum de destaque entre todos os cinco ligantes é que uma ligação de hidrogênio, envolvendo o amino grupo do resíduo Leu83, está presente nas estruturas de todos os complexos binários de CDK2 com ligantes, e mais ainda, tal ligação de hidrogênio é também observada no complexo de CDK2-Ciclina $\mathrm{A}$ com a proteína inibidora $\mathrm{p} 27$, tal informação deveria ser considerada quando se desenhar novos inibidores de CDK2, ou seja, a manuntenção de estruturas de inibidores de CDK2 que conservem a ligação de hidrogênio com o amino grupo da Leu83 da CDK2. 
a)
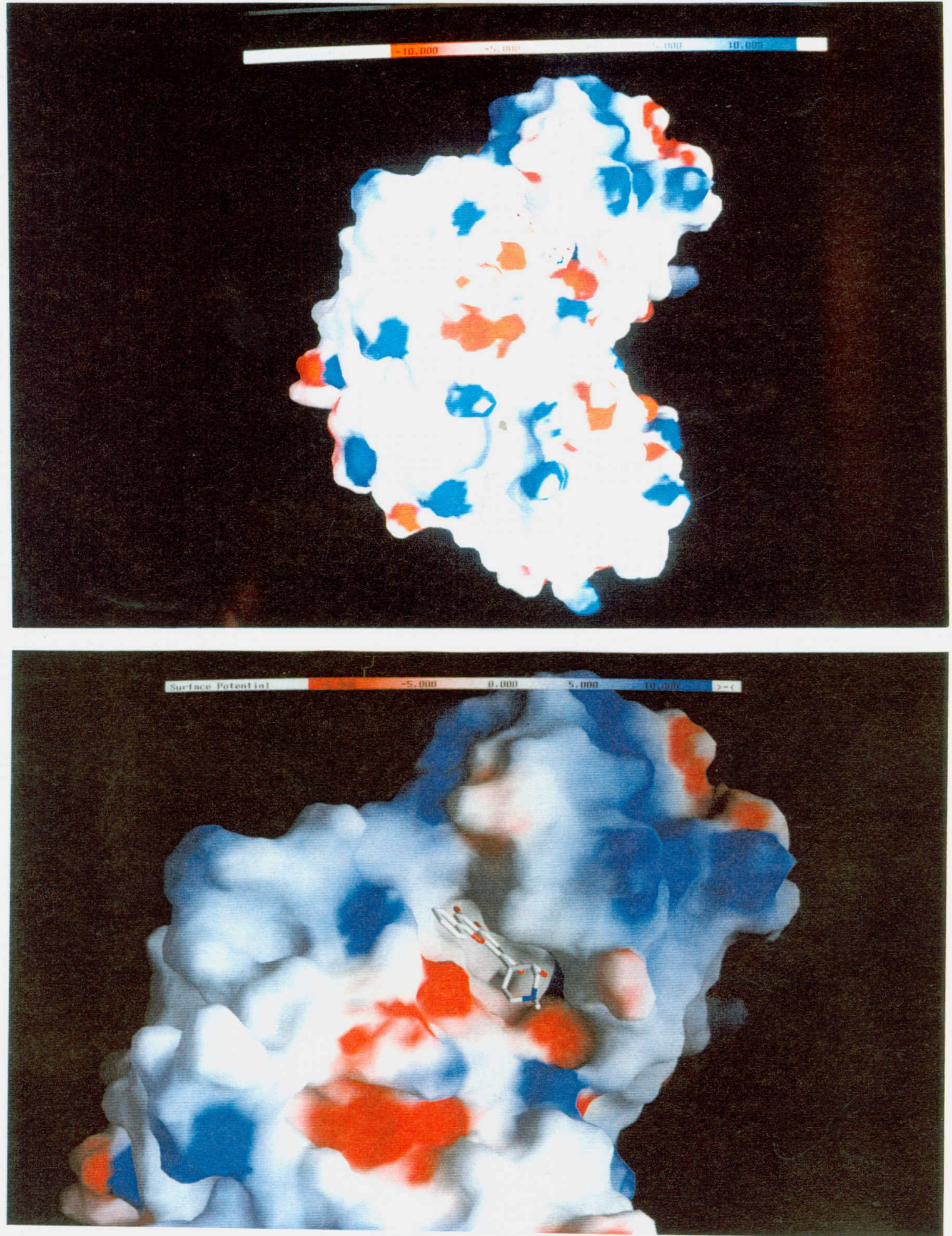

Figura 7.1. Superfície de acessibilidade ao solvente para CDK2-DFP. a) Superfície de acessibilidade ao solvente desenhada com o programa GRASP (Nicholls et al., 1991), b) aumento da região do bolsão de ligação de ATP, mostrando o anel fenil da molécula de DFP apontando para fora do bolsão. 
a)

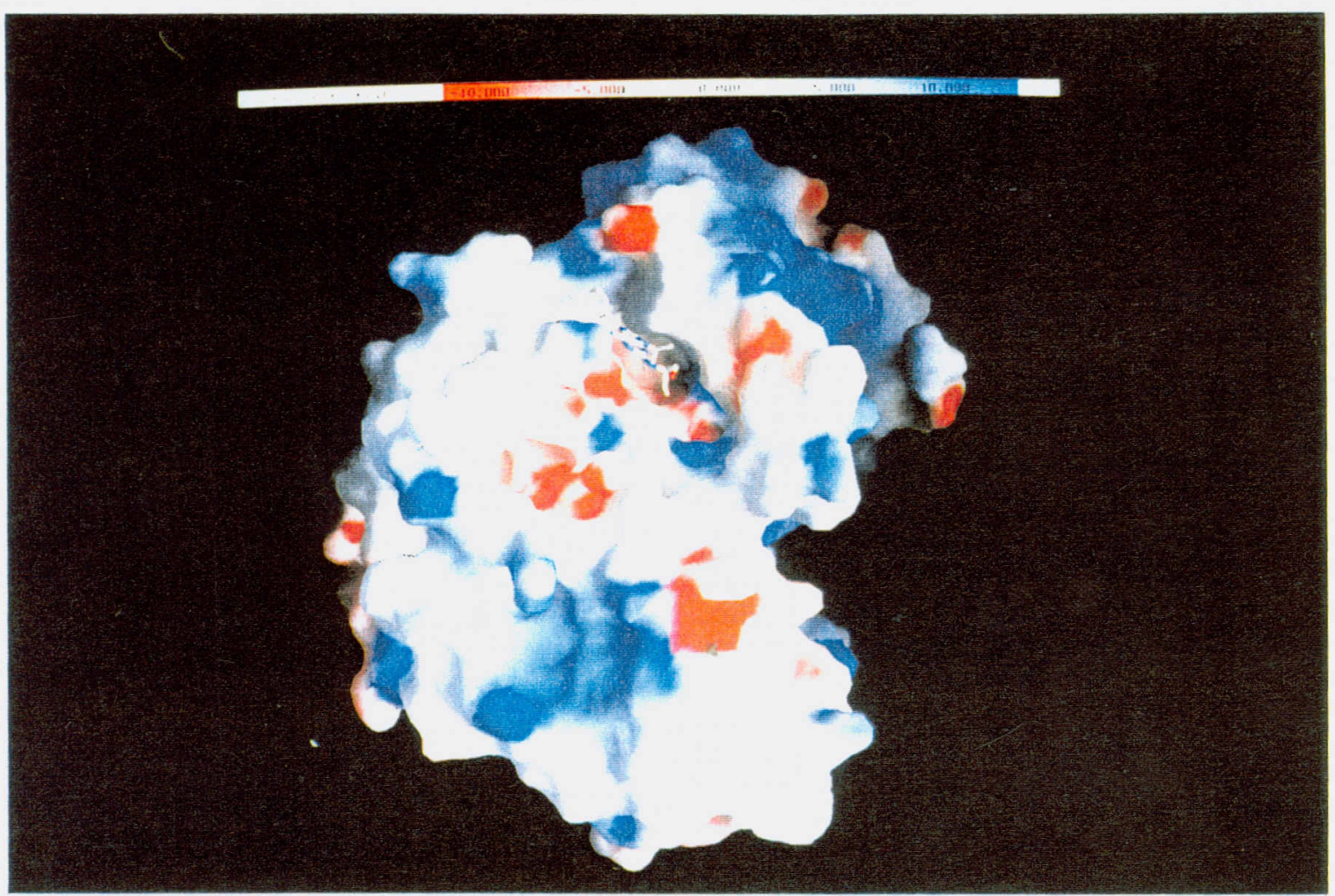

b)

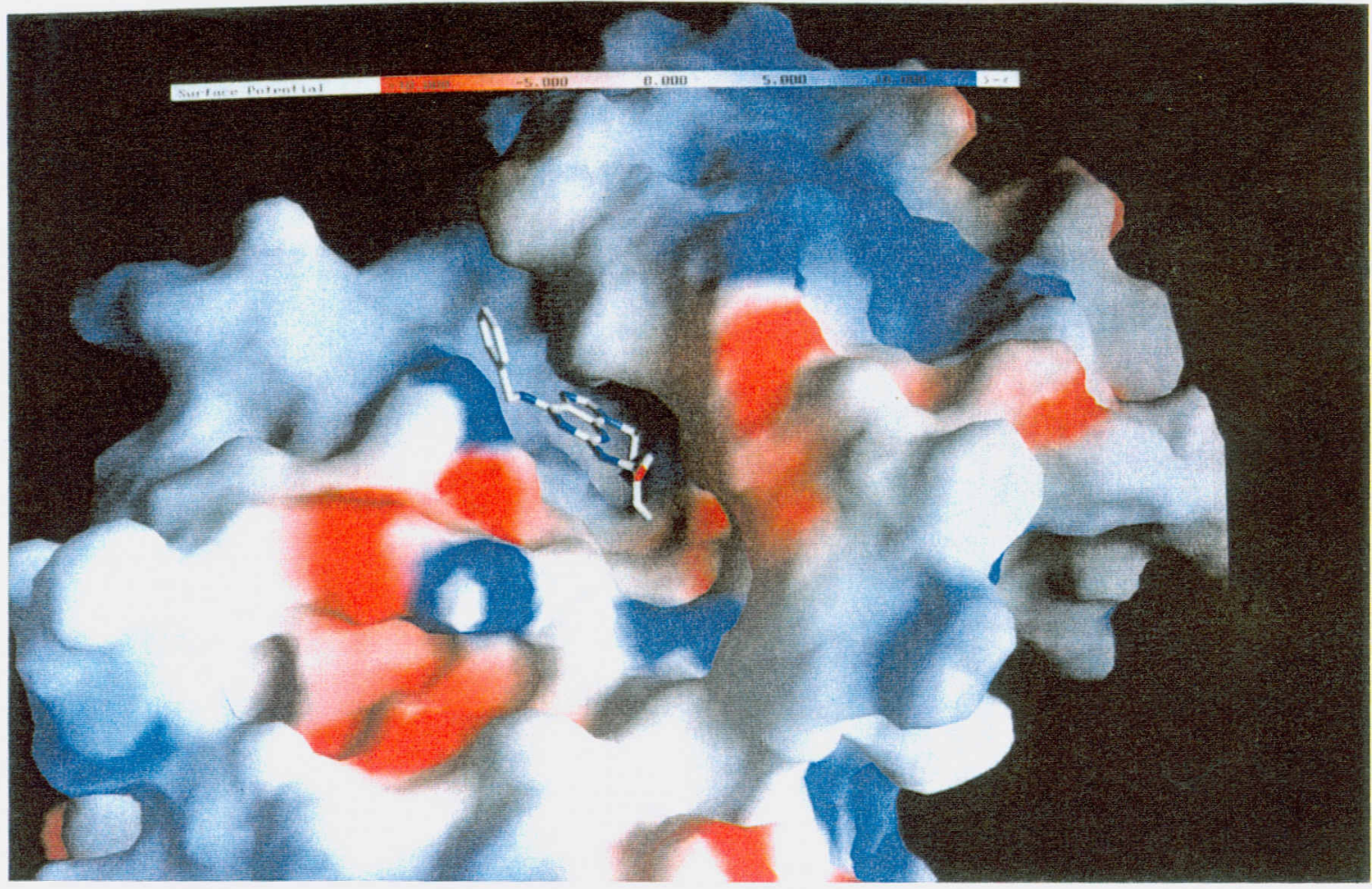

Figura 7.2. Superfície de acessibilidade ao solvente para CDK2-Roscovitine. a) Superficie de acessibilidade ao solvente desenhada com o programa GRASP ( Nicholls et al., 1991), b) aumento da região do bolsão de ligação de ATP, mostrando o anel fenil da molécula de Roscovitine apontando para fora do bolsão. 

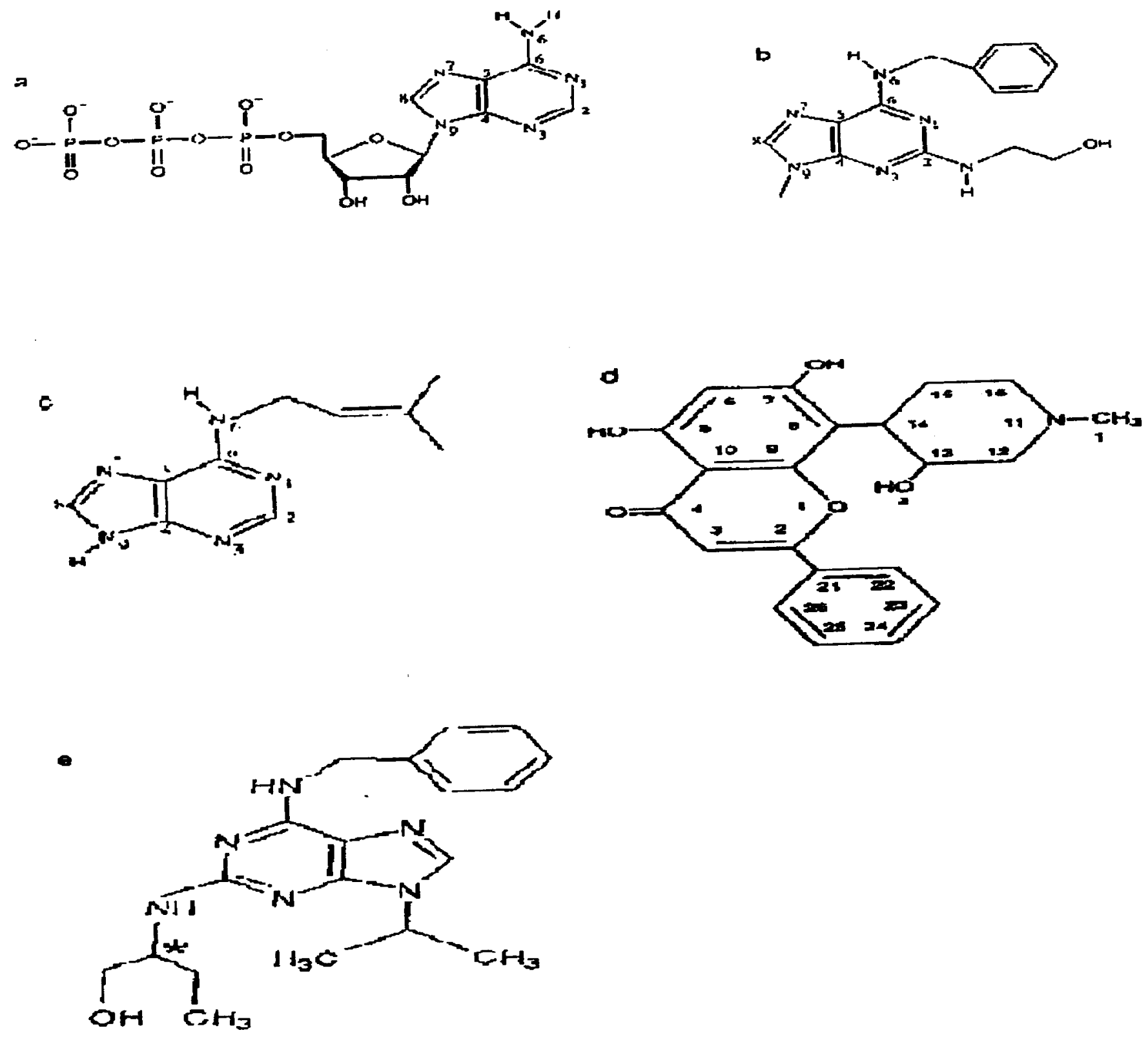

Figura 7.3. Fórmula molecular dos cinco ligantes para os quais se possue informação estrutural até o momento. 


\subsection{Consideracōos finais.}

As estruturas dos complexos entre CDK2 com quatro inibidores nos possibilita explicar a especificidade e potência destes inibidores e sugerir desenho de drogas baseados na estrutura que podem aumentar as chances de se descobrir inibidores melhores e mais específicos para CDK2 e outras CDKs. Muitas lições importantes podem ser tiradas deste estudo (Kim et al., 1996):

(a) O bolsão de ligação de ATP da CDK2 tem a capacidade surpreendente de se ligar a uma variedade de anéis aromáticos com uma variação na posição, de certa forma não previsivel, da cadeia lateral de alguns resíduos do bolsão de ligação.

(b) O conhecimento da orientação do anel de purina da molécula de ATP no bolsão de ligação na estrutura da CDK2-ATP (De Bondt et al.,1993) não nos permitiu prever como o anel de purina da molécula de Roscovitine, Olomoucine e IPA se ligariam à CDK2. A determinação experimental dos complexos de Roscovitine, Olomoucine e IPA nos faz compreender que qualquer desenho racional de drogas ( rational drug design ) baseado na posição do anel de purina da molécula de ATP nos levaria a desconsiderar Roscovitine, Olomoucine e IPA como potencias inibidores de CDK2.

(c) A especificidade de cada inibidor por CDK2 vem da interação entre grupos substituintes, tais como o anel fenil da molécula de Roscovitine, com a superficie periférica do bolsão de ligação de ATP. Esta observação vem contra o conceito normalmente aceito que uma base comum como a purina não pode ser uma boa base para desenho de inibidores pois há muitas proteínas na célula que se ligam aos derivados de purina. Nossos resultados com a estrutura de Roscovitine, mostram claramente que a especificidade pode ser criada por meio de modificações adequadas de uma base molecular comum, como a purina, ou seja, a inserção de grupos substituintes adequados a uma base comum aumenta a especificidade do inibidor pela proteína alvo.

(d) $\mathrm{O}$ conhecimento das estruturas de CDK2 complexada com quatro inibidores sugere duas bases moleculares, o anel purina e o anel benzopirol da molécula de DFP, que 
podem ser usadas para desenho de drogas baseado na estrutura e desenho de uma biblioteca combinatória.

O estudo de estrutural de complexos de CDK2 com inibidores reserva ainda vários desafios. As informações das estruturas acumuladas até o momento se resumem a duas famílias de inibidores, derivados de purina e derivados de flavonas. Entretanto nenhuma informação estrutural está disponivel sobre outras famílias de inibidores, tais como, derivados de staurosporina, que inibem CDKs na faixa de $\mathrm{IC}_{50} \sim \mathrm{nM}$ (Tamaoki et al., 1986). Temos como projeto futuro continuar o estudo estrutural destes complexos no Brasil, mais especificamente no IBILCE/UNESP de São José do Rio Preto, visto que, a maioria dos inibidores de CDK se encontram disponíveis no mercado e um equipamento de raios X Rigaku R-AXIS IV estará funcionando em breve nesse laboratório. 


\section{Referências bibliográficas.}

Arndt, U. W. \& Wonacott, A. J. "The Rotation Method in Crystallography". North-Holland. Amsterdam. 1977.

Ataka, M. and Asai, M. (1988). J. Crystal Growth, 90, 86.

Azároff; L. V. "Elements of X-ray crystallography". McGraw-Hill, Inc. USA. 1968.

Azevedo. W. F. Jr., Mueller-Dieckmann, H.-J., Schulze-Gahmen, U., Worland, P. J., Sausville, E. \& Kim, S. -H. Proc. Natl. Acad. Sci. USA. Vol. 93. pp.2735-2740.

Blackburn, G. M. \& Gait, M. J. "Nucleic Acids in Chemistry and Biology" $2^{\text {nd }}$ ed. Oxford University Press. Hong Kong. 1996.

Blundell, T. L. \& Johnson, L. N. "Protein Crystallography". Academic Press.USA. 1976.

Boistelle, R. and Astier, J. P. (1988). J. Crystal Growth, 90, 14.

Bossemeyer, D. Engh, R. A.; Kinzel, V., Ponstingl, H. \& Huber, R. (1993) EMBO J. 12, 849-859.

Brünger, A. T. (1990) Acta Cryst. A46, 46-57.

Brünger, A. T. (1991) Ann. Rev. Phys. Chem. 42, 197-223.

Brünger, A. T. (1992) X-PLOR Version 3.1 manual. Yale Univ. USA.

Cantor, R. C. \& Schimmel, P. R. "Biophysical chemistry. Volume II". W. H. Freeman and Company. USA. 1980.

Carter, C. W., Jr. \& Carter, C. W. (1979). J. Biol. Chem., 254, 12219.

Cho, Y.; Gorina, S.; Jeffrey, P. D. \& Pavlettich, N. P. Science. 265, 346-355 (1994).

Connoly, M. L. (1983) J. Appl. Crystallogr. 16, 548-558.

Cullity, B. D. "Elements of X-ray crystallography". Addison-Wesley Publishing Company, Inc. USA. 1956. 
De Bondt, H. L., Rosenblatt, J. Jancarik, J., Jones, H. D., Morgan, D. O. \& Kim, S. -H. (1993). Nature (London) 363, 595-602.

Drenth, J. "Principles of Proteins X-Ray Crystallography". Springer-Verlag. New York. USA. 1994.

Ducruix; A. and Giegé, R. Crystallization of Nucleic Acids and Proteins (A Pratical Approach). Oxford University Press, 1992.

Fontes, M. R. M. “Tese de Doutorado”. Instituto de Física de São Carlos. 1995.

Fox, G. C. \& Holmes, K. C. (1966) Acta Cryst., 20, 886.

Giacovazzo, C. "Fundamentals of Crystallography". Oxford Science Publications. Great Britain. 1992.

Green, A. A. (1932). J. Biol. Chem., 95, 47.

Gu, Y.; Rosenblatt, J. \& Morgan, D. O. (1992) EMBO J. 11, 3995-4005.

Hamilton, W. C., Rollet, J. S. \& Sparks, R. A. (1965). Acta Cryst. 18, 129.

Hampel, A., Labananskas, M., Cornners, P. G.; Kirkegard, L., RajBhandary, U. L., Sigler, P. B., and Bock, R. M. (1968). Science, 162, 1384

Hanks, S. K. \& Quinn, A. M. Meth. Enzym. 200, 38-62 (1991).

Harper, J. W., Adami, G. R.; Wei, N.; Keyomarsi, K. \& Elledge, S.J. Cell 75, $805-$ 816 (1993).

Higashi, T. J. Appl. Cryst., 23, 253.

Hirshfeld, F. L. (1968) Acta Crystallogr. A24, 301-311.

Hoppe, J.; Freist, W.; Marutsky, R. \& Shaltiel, S. (1978) Eur. J. Biochem. 90, 427-432.

Howard, S. B., Twigg, P. J., Baird, J. K., and Meehan, E. J., (1988). J. Crystal Growth, 90, 94.

Jancarik, J, \& Kim, S. -H. (1991) J. Appl. Crystallogr. 24, 409-411.

Janin, J. \& Clothia, C. (1990) J. Biol. Chem. 265, 16027-16030, 
Jeffrey, P. D., Russo, A. A., Polyak, K., Gibbs, E., Hurwitz, J., Massagué, J. \&

Pavletich, N. P. (1995) Nature (London) 376, 313-320.

Jones, T. A. (1978) J. Appl. Crystallogr. 23, 434-436.

Jones, T. A., Zou, J. -Y., Cowan, S. W. Acta Crystallogr. A47, 110-120. (1991).

Kabsch, W. (1988). J. Appl. Cryst., 21, 67.

Kaur, G., Steller-Stevenson, M., Seber, S., Wordladm P., Sedlaeck, H., Myers, C., Czech, J., Naik, R. \& Sausville, E. (1992) J. Natl. Cancer Inst. 84, 1736-1740.

Kim, S. -H: Schulze-Gahmen; U. Brandsen, J., Azevedo, Jr. W. F. Progress in Cell Cycle Research, Vol. 2, 137-145. ( Meijer, L., Guidet, S. and Vogel, L. eds) Chapter 14. Plenum Press, New York, USA. 1996.

Kleinsmith, L. J. \& Kish, V. M. "Principles of Cell and Molecular Biology". $2^{\text {nd }} e d$. HarperCollins College Publishers. New York, NY. USA. 1995.

Knighton, D. R., Zheng, J., Ten Eyck, L. F., Ashford. V. A., Xuong, N. -H., Taylor, S. S. \& Sowadski, J. M. Science. 253, 407-414, 1991.

Lipson, H. \& Taylor, C. A. “ Fourier Transforms and X-ray Diffraction”. G. Bell and Sons Ltd. Glasgow. Great Britain. 1958.

Lodish, H., Baltimore, D., Berk, A., Zipursky, S. L. Matsudaira, P. \& Darnel, J. "Molecular Cell Biology". $3^{\text {rd }}$ ed. Freeman and Company, New York. USA. 1995.

Losiewicz, M. D., Carlson, B. A., Sausville, E. A., Nauk, R. G., Narayanan, V. L. $\&$ Worland, P. J. (1995) Proceedings of $88^{\text {th }}$ Annual Meeting of American Association for Cancer Reasearch (Toronto, Canada), Vol. 36, p.35 (abstr)

Losiewicz, M. D., Carlson, B. A., Kaur, G., Sausville, E. A. \& Worland, P. J. (1994) Biochem. Biophys. Res. Commun. 201, 589-595.

McPherson, A., Koszelak, S., Axelrod, H., Day, J., Williams, R., Robinson, L., McGrath, M., and Cascio, D. (1986). J. Biol. Chem., 261, 1969.

McPherson, A. (1990). Eur. J. Biochem., 189, 1.

McRee, D.E. "Pratical Protein Crystallography". Academic Press, Inc. San Diego, USA. (1994).

Meijer, L., Azzi, L. \& Wang, J. Y. J. (1991) EMBO J. 10, 1545-1554. 
Mikol, V. and Giegé, R. (1989). J. Crystal Growth, 97, 324.

Murray, R. K., Granner, D. K.; Mayes, P. A. \& Rodwell, V. W. “ Harper's Biochemistry". $23^{\text {rd }}$ ed. Appleton \& Lange. USA. 1993.

Nicholls, A., Sharp, K. A. \& Konig, H. (1991) Proteins 11, 281-296.

Powell, M. J. D. (1977). Mathematical Programming, 12, 241.

Rao, S. N., Jih, J, -H. \& Hartsuck, J. A. (1980) Acta Cryst. A36, 878-884.

Riès-Kautt, M. M. and Ducruix, A. (1989). J. Biol. Chem., 264, 745.

Riès-Kautt, M. M. and Ducruix, A. (1991). J. Crystal Growth, 110, 20.

Rossmann, M. G. \& Blow, D. M. (1962). Acta Cryst., 15, 24-31.

Rossmann, M. G., Leslie, A. G. W., Abdel-Meguid, S. S. \& Tsukihara, T. (1979). J. Appl. Cryst., 12, 570.

Rosenblatt, J., De Bondt, H., Jancarick, J., Morgan, D. O. \& Kim, S. -H. (1993) J. Mol. Biol. 230, 1317-1319.

Russo, A. A., Jeffrey, P. D., Patten, A. K., Massagué, J. \& Pavletich, N. P. (1996) Nature (London) 382, 325-331.

Sato, M., Yamamoto, M., Imada, K., Katsube, Y., Tanaka, N. \& Higashi, T. (1992) Acta Cryst., 25, 348.

Schulze-Gahmen, U. Brandsen, J., Jones, H. D., Morgan, D. O., Meijer, L., Veseley, J. \& Kim, S. -H. (1995) Proteins Struct. Funct. Genet. 22, 378-391.

Serota, S. \& Radzio-Andzelm, E. (1994) Structure 2, 345-355.

Sherr, C. J. \& Roberts, J. M. Genes Dev. 9, 1831-1845 (1995).

Sheriff, S. Hendrickson, W. A. \& Smith, J. L. (1987) J. Mol. Biol. 197, 273-296.

Sherrwood, D. "Crystals, X-rays and Proteins". Longman Group Ltd. London. Great Britain. 1976. 
Stout, G. H. \& Jensen, L. H. "X-ray Structure Ddetermination". $2^{\text {nd }}$ ed. Wiley, New York. USA. 1989.

Sussman, J. L. Methods Enzymol. (1985) 115B, 271-303.

Tamaoki, T. et al. (1986) Biochem. Biophys. Res. Commun. 135, 397.

Tinoco, I., Jr., Saur, K \& Wang, J. C. "Physical Chemistry. Principles and Applications in Biological Sciences". $3^{\text {rd }}$ ed. Prentice-Hall, Inc. New Jersey. USA. 1995 .

Toyoshima, H. \& Hunter, T. Cell 78, 67-74 (1994).

Usha, R., Johnson, J. E., Moras, D., Thierry, J. -C., Fourme, R., and Kahn, R. (1984). J. Appl. Cryst., 17, 147.

Veseley, J., Havlicek, L., Strnad, M., Blow, J. J., Donella-Deana, A., Pinna, L., Letham, D. S., Kato, J. Y., Détivaud, L., Leclerc, S. \& Meijer, L. (1994). Eur. J. Biochem. 224, 771-786.

Voet, D. \& Voet, J. G. "Biochemistry". $2^{\text {nd }}$ ed. John Wiley \& Sons, Inc.USA. 1995.

von Hippel, P. H. and Schleich, T. (1969). Accounts of Chemical Research, 2, 257.

Wallace, A. C., Laskowski, R. A. \& Thomtom, J. M. (1995) Protein Eng., 8, $127-$ 134.

Wilson, I. A.\& Stanfield, R. L. (1993) Curr. Opin. Struc. Biol. 3, 113-118.

Winkler, F. K., Schutt, C. E. \& Harrison, S. C. (1979). Acta Cryst., A35, 901.

Woolfson, M. M. "An Introduction to X-ray Crystallography". Cambridge University Press, England. 1970.

Zheng, J., Knighton, D. R., Ten Eyck, L. F., Karlsson, R. Xuong, N. -H., Taylor, S. S. \& Sowadski, J. M. (1993) Biochemistry 32, 2154-2161. 
APÊNDICE 1

CONDIÇÕES DE CRISTALIZAÇÃO DO MÉTODO DA MATRIZ ESPARSA

IFSC-USD SERVICOODE RISLIOTECA 
1.

2.

3.

4.

5.

6.

7.

8.

9.

10.

11.

12.

13.

14.

15.

16.

17.

18.

19.

20.

21.

22.

23.

24.

25.

26.

27.

28.

29.

30.

31.

32.

33.

34.

35.

36.

37.

38

39.

40.

41.

42.

43.

44.

45.

46.

47.

48 .

49

50.

51.

52.

53.
SALL

0.05 M Calcium Chloride $0.1 \mathrm{M}$ Acetate

$\cdots$

$0.2 \mathrm{M}$ Sodium Citrate

$0.2 \mathrm{M} \mathrm{Mg}$ Chloride

0.2 M Sodium Citrate

$0.2 \mathrm{M}$ Amm. Acetate

$0.2 \mathrm{M}$ Amm. Acetate

$0.2 \mathrm{M} \mathrm{Mg}$ Chloride

$0.2 \mathrm{M}$ Sodium Citrate

$0.2 \mathrm{M}$ Calcium Chloride

$0.2 \mathrm{M}$ Amm. Sulfate

$0.2 \mathrm{M}$ Lithium Sulfate

$0.2 \mathrm{M} \mathrm{Mg}$ Acetate

$0.2 \mathrm{M}$ Amm. Acetate

$0.2 \mathrm{M}$ Amm. Sulfate

$0.2 \mathrm{M} \mathrm{Mg}$ Acetate

$0.2 \mathrm{M}$ Sodium Acetate

$0.2 \mathrm{M} \mathrm{Mg}$ Chloride

$0.2 \mathrm{M}$ Calclum Chloride

$0.1 \mathrm{M}$ Cadmium Sulfate

$0.2 \mathrm{M}$ Amm. Acetate

$0.2 \mathrm{M}$ Sodium Citrate

$0.2 \mathrm{M}$ Sodium Acetate

$0.2 \mathrm{M}$ Ammonium Sulfate

$0.2 \mathrm{M}$ Ammonium Sulfate

$\ldots$

-..-

$---$

$\cdots$

$\cdots$

$\cdots$

$\cdots$

O.05 M Potas. Phosphate

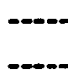

$0.2 \mathrm{M} \mathrm{Zn}$ Acetate

$0.2 \mathrm{M} \mathrm{Ca}$ Acetate

$0.8 \mathrm{M}$ Lithium Sulfate

1.0 M Lithium Sulfate

-.-.-

0.1 M Cd Chloride

0.02 M Cd Chloride

\section{$0.1 M$ Tris}

$0.1 \mathrm{M}$ Hepes

$0.1 \mathrm{M}$ Tris

0.1 M Cacodylate

0.1 M Cacodylate

0.1 M Citrate

0.1 M Acetate

$0.1 \mathrm{M}$ Citrate

$0.1 \mathrm{M}$ Hepes

$0.1 \mathrm{M}$ Tris

$0.1 \mathrm{M}$ Hepes

0.1 M Cacodylate

$0.1 \mathrm{M}$ Hepes

0.1 M Tris

0.1 M Cacodylate

$0.1 \mathrm{M}$ Tris

0.1 M Acetate

0.1 M Cacodylate

$0.1 \mathrm{M}$ Tris

$0.1 \mathrm{M}$ Hepes

0.1 M Acetate

$0.1 \mathrm{M}$ Hepes

$0.1 \mathrm{M}$ Citric

$0.1 \mathrm{M}$ Hepes

0.1 M Cacodylate

$0.1 \mathrm{M}$ Hepes

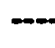

$\cdots$

0.1 M Acetate

$0.1 \mathrm{M}$ Hepes

$0.1 \mathrm{M}$ Tris

0.1 M Acetate

$0.1 \mathrm{M}$ Hepes

$0.1 \mathrm{M}$ Hepes

0.1 M Citrate

$0.1 \mathrm{M}$ Tris

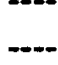

0.1 M Cacodylate

$0.1 \mathrm{M}$ Tris

0.1 M Acetate

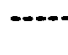

$0.1 \mathrm{M}$ Hepes

0.1 M Acetate

$0.1 \mathrm{M}$ Hepes
$30 \%$ MPD

$0.4 \mathrm{M} \mathrm{Na}, \mathrm{K}$ Tartrate

$0.4 \mathrm{M} \mathrm{Amm}$. Phosphate

2.0 M Amm. Sulfate

$40 \%$ MPD

$30 \%$ PEG $4 \mathrm{~K}$

1.5 M Sodium Acetate

$30 \%$ Isopropanol

$30 \%$ PEG $4 \mathrm{~K}$

$30 \%$ PEG $4 \mathrm{~K}$

1.0 M Amm. Phosphate

$30 \%$ isopropanol

$30 \%$ PEG 400

$28 \%$ PEG 400

$30 \%$ PEG $8 \mathrm{~K}$

$1.5 \mathrm{M}$ Lithium Sulfate

$30 \%$ PEG $4 \mathrm{~K}$

$25 \%$ Peg $8 \mathrm{~K}$

$30 \%$ isopropanol

$25 \%$ Peg $4 \mathrm{~K}$

$30 \%$ MPD

$30 \%$ PEG $4 \mathrm{~K}$

$30 \%$ PEG 400

$20 \%$ Isopropanol

$1.0 \mathrm{M}$ Sodium Acetate

$30 \%$ MPD

$20 \%$ Isopropanol

$30 \%$ PEG $8 \mathrm{~K}$

$0.8 \mathrm{M} \mathrm{Na}, \mathrm{K}$ Tartrate

$30 \%$ PEG $8 \mathrm{~K}$

$30 \%$ PEG $4 \mathrm{~K}$

2.0 M Amm. Sulfate

4.0 M Sodium Formate

$2.0 \mathrm{M}$ Sodium Formate

1.6 M Na, K, Phosphate

$8 \%$ PEG $8 \mathrm{~K}$

$8 \%$ PEG $4 K$

$1.4 \mathrm{M} \mathrm{Na}$ Citrate

$2 \%$ PEG 400, 2.0 M A.S.

20\%lsopropanol 20\%PEG4K

10\% lsopropanol 20\%PEG4K

$20 \%$ PEG $8 \mathrm{~K}$

$30 \%$ PEG 1500

$0.2 \mathrm{M} \mathrm{Mg}$ Formate

$18 \%$ PEG $8 \mathrm{~K}$

$18 \%$ PEG $8 \mathrm{~K}$

2.0 MAmm.Sulfate5\%lsopropanol

$2 \%$ PEG $8 \mathrm{~K}$

$10 \%$ PEG $8 \mathrm{~K}$

$1.0 \mathrm{M}$ Imidazol

70\% MPD

$30 \%$ PEG 400

$30 \%$ PEG $4 \mathrm{~K}$ 
54.

55.

56.

57.

58.

$12 \%$ Glycerol

$10 \%$ ETOH
$0.1 \mathrm{M}$ Hepes

$0.1 \mathrm{M}$ Tris

0.1 M Glycine
$70 \%$ saturated $\mathrm{NaCl}$ $1.5 \mathrm{M}$ Ammon. Sulfate $5 \%$ PEG 20,000 $10 \%$ PEG $1 K+10 \% 8 K$ $1.5 \mathrm{M} \mathrm{NaCl}$ 
APÊNDICE 2

ARQUIVOS DE TOPOLOGIA USADOS NO REFINAMENTO DO DFP 
Remarks benzo.par

Remarks Created by XPLO2D V. 950116/1.2.2 at Thu Dec 14 15:48:17 1995 for user azevedo

Remarks Auto-generated by XPLO2D from file benzophe.pdb

Remarks Parameters for residue type $L 76$

set echo=false end

\{ edit if necessary \}

BOND OX1 CX2

BOND OX1 CX4

$1000.01 .360 !$ Nobs $=1$

BOND CX2 CX3 1000.01 .395 ! Nobs $=1$

BOND CX2 CX16 $1000.01 .540 !$ Nobs $=1$

BOND CX3 CX4 1000.01 .395 ! Nobs $=1$

BOND CX4 CX6 1000.01 .395 ! Nobs $=2$

BOND CX4 OX8 $1000.01 .245 !$ Nobs $=1$

BOND CX5 CX9 1000.01 .395 ! Nobs $=2$

BOND CX5 CX6 1000.01 .395 ! Nobs $=1$

BOND CX5 $0 \times 7 \quad 1000.01 .428$ ! Nobs $=1$

BOND CX5 CX10 1000.01 .395 ! Nobs $=1$

BOND CX5 OX17 1000.01 .427 ! Nobs $=1$

BOND CX10 CX4 1000.01 .395 ! Nobs $=1$

BOND CX16 CX11 1000.01 .395 ! Nobs $=1$

BOND CX16 CX15 1000.01 .395 ! Nobs $=1$

BOND CX11 CX12 1000.01 .395 ! Nobs $=1$

BOND CX12 CX13 1000.01 .395 ! Nobs $=1$

BOND CX13 CX14 1000.01 .395 ! Nobs $=1$

BOND CX14 CX15 1000.01 .395 ! Nobs $=1$

\{ piperidinyl's bond length

BOND CY1 CY6 1000.01 .540 ! Nobs $=1$

BOND CY1 CY8 1000.01 .540 ! Nobs $=1$

BOND CY6 CY2 1000.01 .540 ! Nobs $=1$

BOND CY2 CY7 1000.01 .540 ! Nobs $=1$

BOND CY2 OY4 1000.01 .470 ! Nobs $=1$

BOND CY7 NY3 1000.01 .470 ! Nobs $=1$

BOND NY3 CY8 1000.01 .470 ! Nobs $=1$

BOND NY3 CY5 1000.01 .470 ! Nobs $=1$

\{bond length connecting piperidinyl to the rest of molecule

BOND CY6 CX10 5000.0 1.540! Nobs = 1

\{ edit if necessary

ANGLe $\mathrm{CX} 2$ OX1 $\mathrm{CX} 4$

$500.0120 .00 !$ Nobs $=1$

ANGLe OX1 CX2 CX3 $500.0 \quad 120.00$ ! Nobs $=1$

ANGLe OX1 $\quad C \times 2 \quad C \times 16 \quad 500.0 \quad 120.00$ ! Nobs $=1$

ANGLe CX3 CX2 CX16 $500.0 \quad 120.00$ ! Nobs $=1$

ANGLe CX2 $\begin{array}{llll}C \times 3 & C \times 4 & 500.0 & 120.00\end{array}$ ! Nobs $=1$

ANGLe CX3 CX4 CX6 $500.0 \quad 120.00$ ! Nobs $=1$

ANGLe CX3 CX4 OX8 $500.0 \quad 120.00$ ! Nobs $=1$

ANGLe CX6 CX4 OX8 $500.0 \quad 120.00$ ! Nobs $=1$

ANGLe CX9 CX5 CX6 $500.0 \quad 120.00$ ! Nobs $=1$

ANGLe CX9 CX5 OX7 $500.0 \quad 120.00$ ! Nobs $=1$

ANGLe CX6 CX5 OX7 $500.0 \quad 120.00$ ! Nobs $=1$

ANGLe CX5 CX9 CX5 $500.0 \quad 120.00$ ! Nobs $=1$

ANGLe CX9 $C X 5 \quad C \times 10 \quad 500.0 \quad 120.00$ ! Nobs $=1$

ANGLe CX9 CX5 OX17 $500.0 \quad 120.00$ ! Nobs $=1$ 


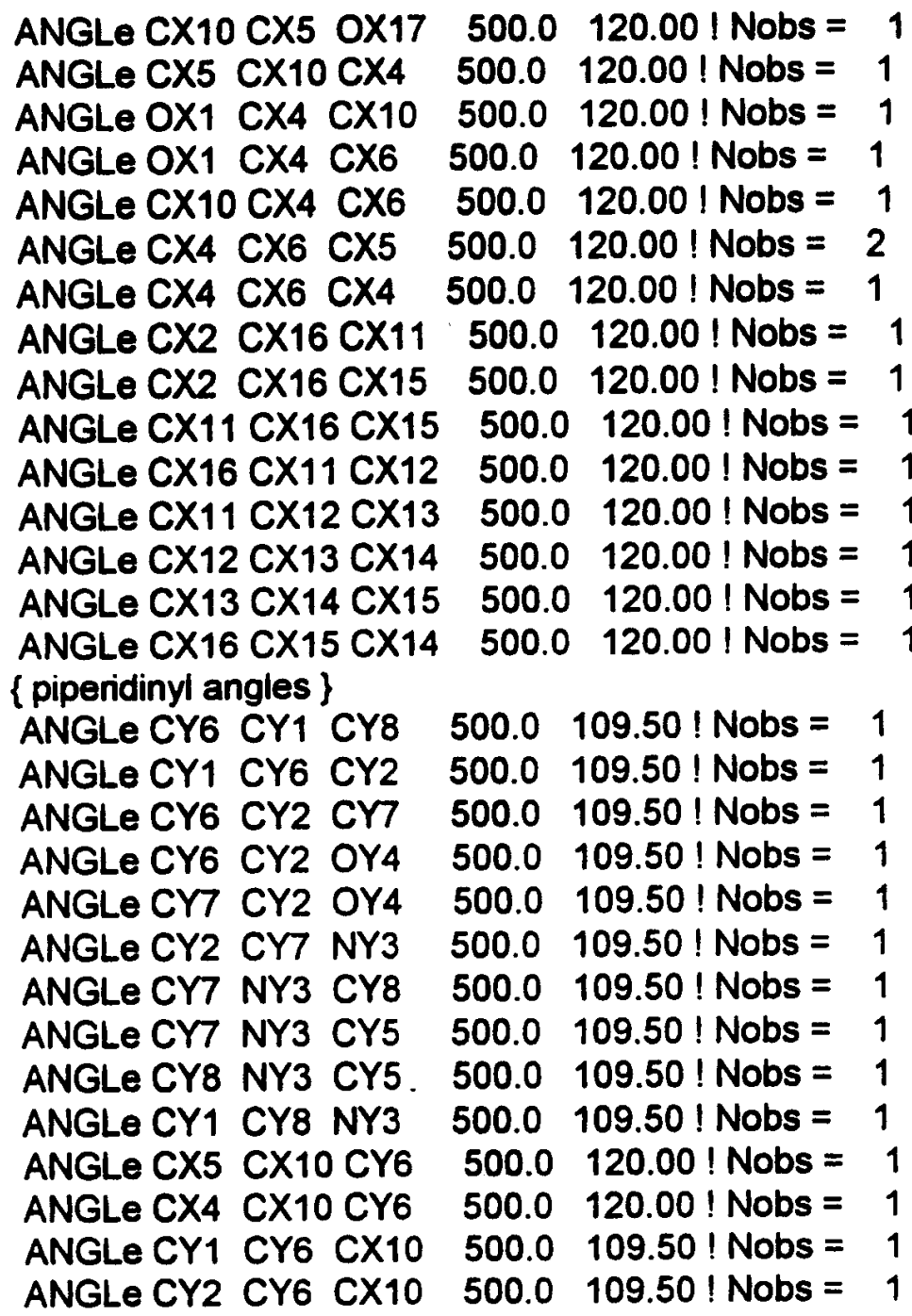

\{ insert DIHEdrals yourself if necessary

\begin{tabular}{|c|c|c|c|c|c|c|}
\hline & & & & & & \\
\hline & $0 \times 1$ & $\mathrm{CX} 2$ & CX3 & 500.0 & 1 & 0.00 \\
\hline dihe $\mathrm{CX} 4$ & $0 \times 1$ & $\mathrm{CX} 2$ & CX16 & 1.0 & 1 & 180.00 \\
\hline$\times 2$ & $0 \times 1$ & $C \times 4$ & $\mathrm{CX} 10$ & 500.0 & 1 & 180.00 \\
\hline$\times 2$ & $0 \times 1$ & $\mathrm{CX} 4$ & $c \times 6$ & 500.0 & 1 & 0.00 \\
\hline$x_{1}$ & $\mathrm{C} \times 2$ & $\mathrm{CX} 3$ & $C \times 4$ & 500.0 & 1 & 0.00 \\
\hline$C \times 16$ & $c \times 2$ & $c \times 3$ & $\mathrm{CX} 4$ & 500.0 & 1 & 180.00 \\
\hline$\times 1$ & $\mathrm{CX} 2$ & $C \times 16$ & $\mathrm{CX} 11$ & 500.0 & 1 & 0.00 \\
\hline$\times 1$ & $c \times 2$ & $\mathrm{C} \times 16$ & $\mathrm{C} \times 15$ & 500.0 & 1 & 180.00 \\
\hline$\times 3$ & $\mathrm{CX} 2$ & $\mathrm{C} \times 16$ & $\mathrm{CX} 11$ & 500.0 & 1 & 180.00 \\
\hline $\mathrm{CX} 3$ & $\mathrm{CX} 2$ & $\mathrm{C} \times 16$ & CX15 & 500.0 & 1 & 0.00 \\
\hline dihe $\mathrm{CX} 2$ & $\mathrm{C} \times 3$ & $C \times 4$ & $\mathrm{CX} 6$ & 500.0 & 1 & 0.00 \\
\hline dihe $\mathrm{CX} 2$ & $\mathrm{C} \times 3$ & $C \times 4$ & $0 \times 8$ & 500.0 & 1 & 180.00 \\
\hline $\mathrm{C} \times 3$ & $\mathrm{CX} 4$ & CX6 & $\mathrm{C} \times 5$ & 500.0 & 1 & 180.00 \\
\hline$c \times 3$ & $C \times 4$ & $C \times 6$ & $\mathrm{CX} 4$ & 1.0 & 1 & -0.00 \\
\hline$\times 8$ & CX4 & $\mathrm{CX} 6$ & $C \times 5$ & 500.0 & 1 & 0.00 \\
\hline he $0 \times 8$ & CX4 & $c \times 6$ & $C \times 4$ & 500.0 & 1 & 180.00 \\
\hline CX6 & CX5 & $\mathrm{C} \times 9$ & $c \times 5$ & 500.0 & 1 & 0.00 \\
\hline $0 \times 7$ & $c \times 5$ & CX9 & CX5 & 500.0 & 1 & 180.00 \\
\hline e $C \times 9$ & $\mathrm{CX} 5$ & $c \times 6$ & $\mathrm{CX} 4$ & 1.0 & 1 & 180.00 \\
\hline ! dihe CX9 & $C \times 5$ & $c \times 6$ & $C \times 4$ & 1.0 & 1 & -0.00 \\
\hline $0 \times 7$ & $C \times 5$ & $\mathrm{CX} 6$ & $\mathrm{CX} 4$ & 500.0 & 1 & 0.00 \\
\hline ! dine $0 \times 7$ & $C \times 5$ & $\mathrm{CX} 6$ & $\mathrm{CX} 4$ & 1.0 & 1 & 80.00 \\
\hline
\end{tabular}




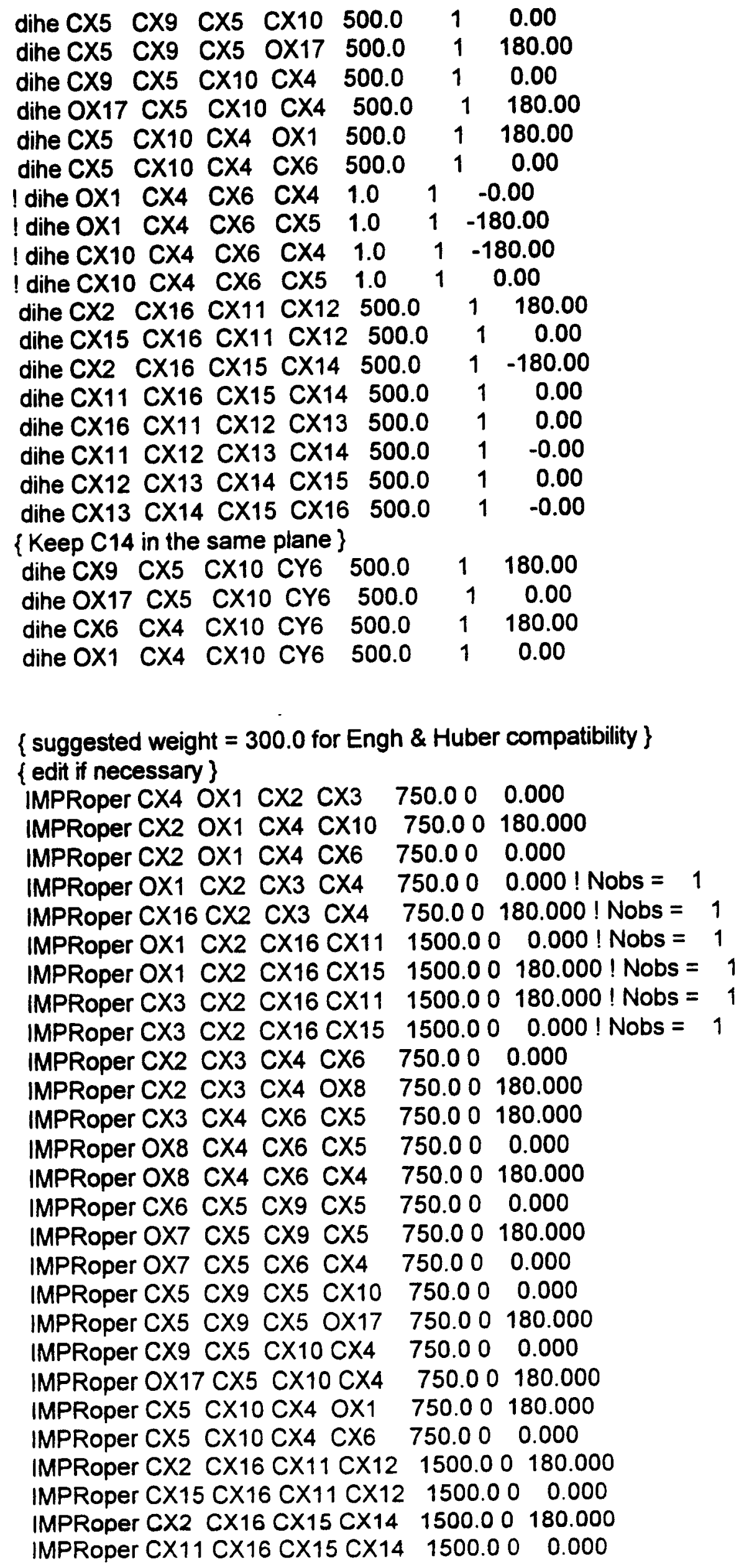


IMPRoper CX16 CX11 CX12 CX13 $1500.00 \quad 0.000$

IMProper CX11 CX12 CX13 CX14 $1500.00 \quad 0.000$

IMPRoper CX12 CX13 CX14 CX15 $1500.00 \quad 0.000$

IMPRoper CX13 CX14 CX15 CX16 $1500.00 \quad 0.000$

\{Keep $\mathrm{C} 14$ in the same plane $\}$

IMPRoper CX9 CX5 CX10 CY6 1500.00180 .000

IMPRoper OX17 CX5 CX10 CY6 $1500.00 \quad 0.000$

IMPRoper CX6 CX4 CX10 CY6 $1500.00 \quad 180.000$

IMPRoper OX1 CX4 CX10 CY6 $1500.00 \quad 0.000$

! IMPRoper CX6 CX4 CX5 CX4 $750.00 \quad 0.000$ ! Nobs $=1$ ! IMPRoper CX16 CX2 CX11 CX15 $750.00 \quad 0.000$ ! Nobs $=1$

\{ edit if necessary

NONBonded OX1 0.15912 .8509

NONBonded CX2 0.12003 .7418

NONBonded CX3 0.12003 .7418

NONBonded CX4 0.12003 .7418

NONBonded CX5 0.12003 .7418

NONBonded CX6 0.12003 .7418

NONBonded OX7 0.15912 .8509

NONBonded OX8 0.15912 .8509

NONBonded CX9 $0.1200 \quad 3.7418$

NONBonded CX10 0.12003 .7418

NONBonded CX11 0.12003 .7418

NONBonded CX12 0.12003 .7418

NONBonded CX13 0.12003 .7418

NONBonded CX14 0.12003 .7418

NONBonded CX15 0.12003 .7418

NONBonded CX16 0.12003 .7418

NONBonded OX17 0.15912 .8509

0.15912 .8509

0.10003 .3854

0.10003 .3854

0.10003 .3854

0.10003 .3854

0.10003 .3854

0.15912 .8509

0.15912 .8509

0.10003 .3854

0.10003 .3854

0.10003 .3854

0.10003 .3854

0.10003 .3854

0.10003 .3854

0.10003 .3854

0.10003 .3854

0.15912 .8509

\{piperidinyl\}

NONBonded CY1 0.12003 .7418

NONBonded CY2 0.12003 .7418

NONBonded NY3 0.23842 .8509

NONBonded OY4 0.15912 .8509

NONBonded CY5 0.12003 .7418

NONBonded CY6 0.12003 .7418

0.10003 .3854

0.10003 .3854

0.23842 .8509

0.15912 .8509

0.10003 .3854

0.10003 .3854

$\begin{array}{lllll}\text { NONBonded CY7 } & 0.1200 & 3.7418 & 0.1000 & 3.3854\end{array}$

NONBonded CY8 $0.1200 \quad 3.7418 \quad 0.1000 \quad 3.3854$

set echo=true end 
Remarks benzo.top

Remarks Created by XPLO2D V. 950116/1.2.2 at Thu Dec 14 15:48:09 1995 for user azevedo

Remarks Auto-generated by XPLO2D from file benzophe.pdb

Remarks You "MUST* checkledit MASSes and CHARges !!!

Remarks Check DONOrs and ACCEptors

Remarks Verify IMPRopers yourself

Remarks UNcomment any DIHEdrals you want to use

set echo=false end

\{ edit masses yourself !!! \}

MASS OX1 15.99940 ! ADD 1.008 for each $\mathrm{H}$ MASS CX2 12.01100 ! ADD 1.008 for each $\mathrm{H}$ MASS CX3 12.01100 ! ADD 1.008 for each $H$ MASS CX4 12.01100 ! ADD 1.008 for each $H$ MASS CX5 12.01100 ! ADD 1.008 for each $H$ MASS CX6 12.01100 ! ADD 1.008 for each $H$ MASS OX7 15.99940! ADD 1.008 for each $H$ MASS OX8 15.99940 ! ADD 1.008 for each $H$ MASS CX9 12.01100 ! ADD 1.008 for each $\mathrm{H}$ MASS CX10 12.01100 ! ADD 1.008 for each $H$ MASS CX11 12.01100 ! ADD 1.008 for each $\mathrm{H}$ MASS CX12 12.01100! ADD 1.008 for each $H$ MASS CX13 12.01100 ! ADD 1.008 for each $H$ MASS CX14 12.01100! ADD 1.008 for each $H$ MASS CX15 12.01100 ! ADD 1.008 for each $H$ MASS CX16 12.01100 ! ADD 1.008 for each $H$ MASS OX17 15.99940! ADD 1.008 for each $\mathrm{H}$ \{piperidinyl\}

MASS CY1 12.01100 ! ADD 1.008 for each $H$ MASS CY2 12.01100 ! ADD 1.008 for each $\mathrm{H}$ MASS NY3 14.00670! ADD 1.008 for each $H$ MASS OY4 15.99940! ADD 1.008 for each $H$ MASS CY5 12.01100 ! ADD 1.008 for each $H$ MASS CY6 12.01100! ADD 1.008 for each $H$ MASS CY7 12.01100! ADD 1.008 for each $H$ MASS CY8 12.01100 ! ADD 1.008 for each $\mathrm{H}$

autogenerate angles=true end

RESIdue L76

$$
\begin{aligned}
& \text { GROUp } \\
& \text { ATOM O1 TYPE OX1 CHARge } 0.0 \text { END } \\
& \text { ATOM C2 TYPE CX2 CHARge } 0.0 \text { END } \\
& \text { ATOM C3 TYPE CX3 CHARge 0.0 END } \\
& \text { ATOM C4 TYPE CX4 CHARge } 0.0 \text { END } \\
& \text { ATOM C5 TYPE CX5 CHARge 0.0 END } \\
& \text { ATOM C6 TYPE CX9 CHARge } 0.0 \text { END } \\
& \text { ATOM C7 TYPE CX5 CHARgE 0.0 END } \\
& \text { ATOM C8 TYPE CX10 CHARge 0.0 END } \\
& \text { ATOM C9 TYPE CX4 CHARge 0.0 END } \\
& \text { ATOM C10 TYPE CX6 CHARge 0.0 END } \\
& \text { ATOM O5 TYPE OX7 CHARge 0.0 END }
\end{aligned}
$$


ATOM 07 TYPE OX17 CHARge 0.0 END ATOM 04 TYPE OX8 CHARge 0.0 END ATOM C21 TYPE CX16 CHARge 0.0 END ATOM C22 TYPE CX11 CHARge 0.0 END ATOM C23 TYPE CX12 CHARge 0.0 END ATOM C24 TYPE CX13 CHARge 0.0 END ATOM C25 TYPE CX14 CHARge 0.0 END ATOM C26 TYPE CX15 CHARge 0.0 END ATOM C15 TYPE CY1 CHARge O.0 END ATOM C14 TYPE CY6 CHARge 0.0 END ATOM C13 TYPE CY2 CHARge O.0 END ATOM C12 TYPE CY7 CHARge 0.0 END ATOM N TYPENY3 CHARge 0.0 END ATOM C16 TYPE CY8 CHARge 0.0 END ATOM O3 TYPE OY4 CHARge 0.0 END ATOM C1 TYPE CY5 CHARge 0.0 END

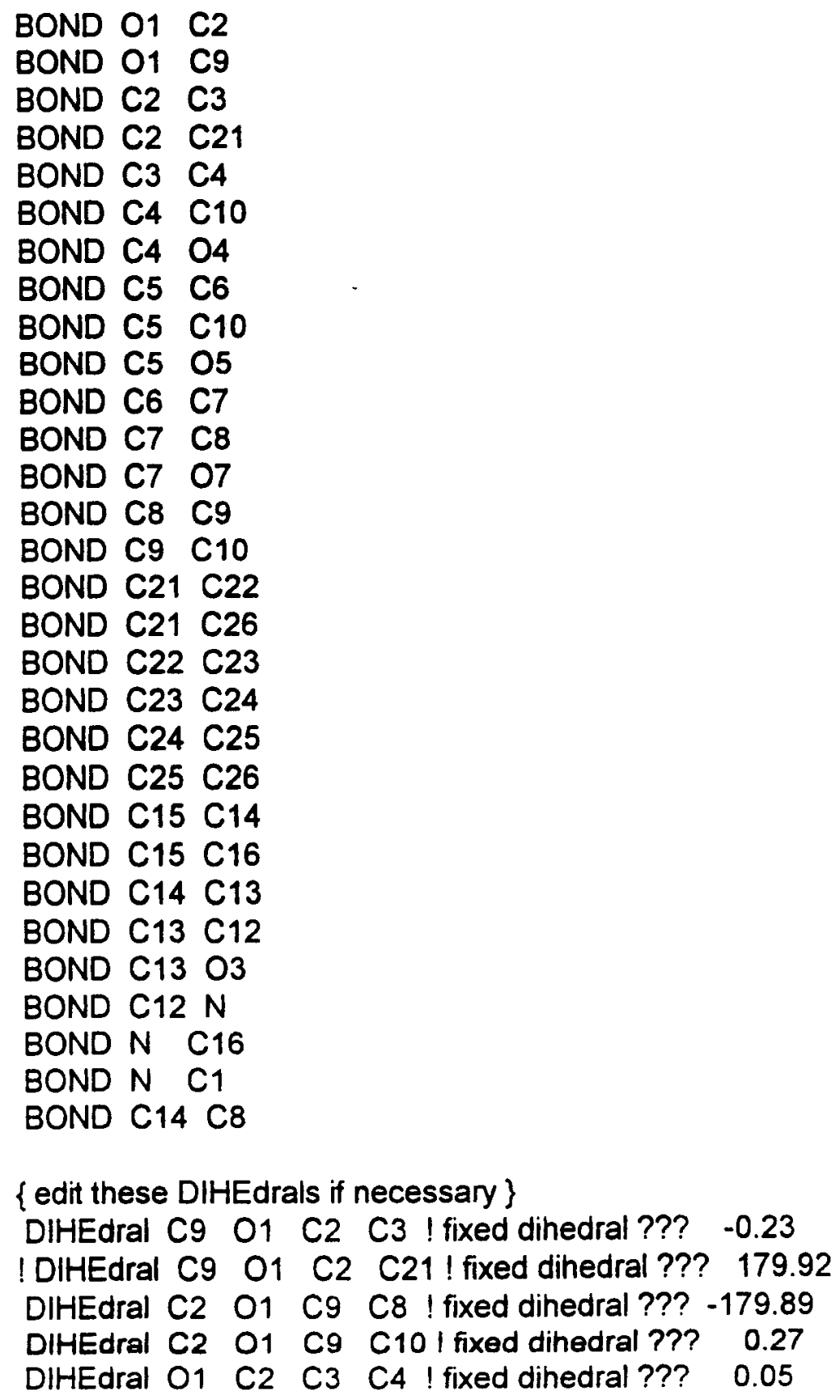


DIHEdral C21 C2 C3 C4 Ifixed dihedral ??? 179.91

DIHEdral 01 C2 C21 C22 ! fixed dihedral ??? -0.09

DIHEdral O1 C2 C21 C26 ! fixed dihedral ??? 179.86

DIHEdral C3 C2 C21 C22 ! fixed dihedral ??? -179.93

DIHEdral C3 $\quad$ C2 $\quad$ C21 C26 ! fixed dihedral ??? 0.01

DIHEdral C2 $\quad$ C3 $\quad$ C4 $\quad$ C10 ! fixed dihedral ??? 0.07

DIHEdral C2 2 C3 $\quad$ C4 04 ! fixed dihedral ??? 179.88

DIHEdral C3 C4 C10 C5 ! fixed dihedral ??? 179.80

! DIHEdral C3 C4 C10 C9 ! fixed dihedral ??? -0.04

DIHEdral 04 C4 C10 C5 ! fixed dihedral ??? -0.01

DIHEdral O4 C4 C10 C9 ! fixed dihedral ??? -179.85

DIHEdral C10 C5 C6 C7 ! fixed dihedral ??? 0.07

DIHEdral O5 C5 $\quad$ C6 $\quad$ C7 ! fixed dihedral ??? 179.87

! DIHEdral C6 C5 C10 C4 ! fixed dihedral ??? 179.99

I DIHEdral C6 C5 C10 C9 ! fixed dihedral ??? -0.17

DIHEdral O5 C5 C10 C4 ! fixed dihedral ??? 0.19

! DIHEdral O5 C5 C10 C9 ! fixed dihedral ??? -179.97

DIHEdral C5 $\quad$ C6 $\quad$ C7 $\quad$ C8 ! fixed dihedral ??? 0.01

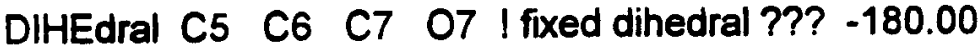

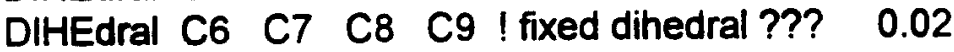

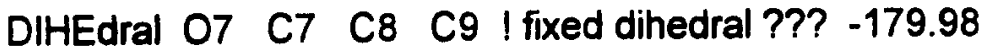

DIHEdral C7 C8 $\quad$ C9 01 ! fixed dihedral ??? -179.96

DIHEdral C7 C8 C9 C10 ! fixed dihedral ??? $\quad-0.12$

! DIHEdral 01 C9 $C 10$ C4 ! fixed dihedral ??? -0.13

! DIHEdral O1 C9 C10 C5 ! fixed dihedral ??? -179.96

! DIHEdral C8 C9 C10 C4 ! fixed dihedral ??? -179.97

! DIHEdral C8 C9 C10 C5 ! fixed dihedral ??? 0.19

DIHEdral C2 C21 C22 C23 ! fixed dihedral ??? 179.97

DIHEdral C26 $\quad$ C21 C22 C23 ! fixed dihedral ??? 0.02

DIHEdral C2 $\quad$ C21 $\quad$ C26 C25 ! fixed dihedral ??? $\quad-179.87$

DIHEdral C22 $\quad$ C21 $\quad$ C26 $\quad$ C25 ! fixed dihedral ??? 0.08

DIHEdral C21 C22 C23 C24 ! fixed dihedral ??? 0.00

DIHEdral C22 C23 C24 C25 ! fixed dihedral ??? -0.12

DIHEdral C23 C24 C25 C26 ! fixed dihedral ??? 0.22

DIHEdral C24 C25 C26 C21 ! fixed dihedral ??? -0.20

DIHEdral C6 $\quad$ C7 $\quad$ C8 $\quad$ C14 ! fixed dihedral ??? 180.00

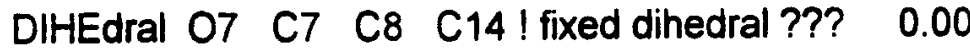

DIHEdral C10 C9 C8 C14 ! fixed dihedral ??? 180.00

DIHEdral 01 C9 $\quad$ C8 $\quad$ C14 ! fixed dihedral ??? 0.00

\{ edit these IMPRopers if necessary \}

IMPRoper C9 $01 \quad \mathrm{C} 2 \quad \mathrm{C} 3$

IMPRoper C2 O1 C9 C8

IMPRoper C2 $01 \quad \mathrm{C} 9 \mathrm{C} 10$

IMPRoper O1 C2 C3 C4 ! chirality or flatness improper 0.08

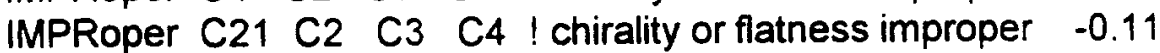

IMPRoper $01 \quad$ C2 $\quad$ C21 $\quad$ C22 ! chirality or flatness improper -0.11

IMPRoper $01 \quad$ C2 $\quad$ C21 C26 ! chirality or flatness improper 0.00

$\begin{array}{llllll}\text { IMPRoper C3 } & \text { C2 } & \text { C21 } & \text { C22 } \text { ! chirality or flatness improper } 0.09\end{array}$

IMPRoper C3 C2 C21 C26 ! chirality or flatness improper 0.09

IMPRoper C2 $\mathrm{C} 3 \mathrm{C} 4 \mathrm{C} 10$

IMPRoper $\mathrm{C}_{2} \quad \mathrm{C} 3 \quad \mathrm{C} 4 \quad \mathrm{O} 4$

IMPRoper C3 C4 C10 C5

IMPRoper O4 C4 C10 C5 


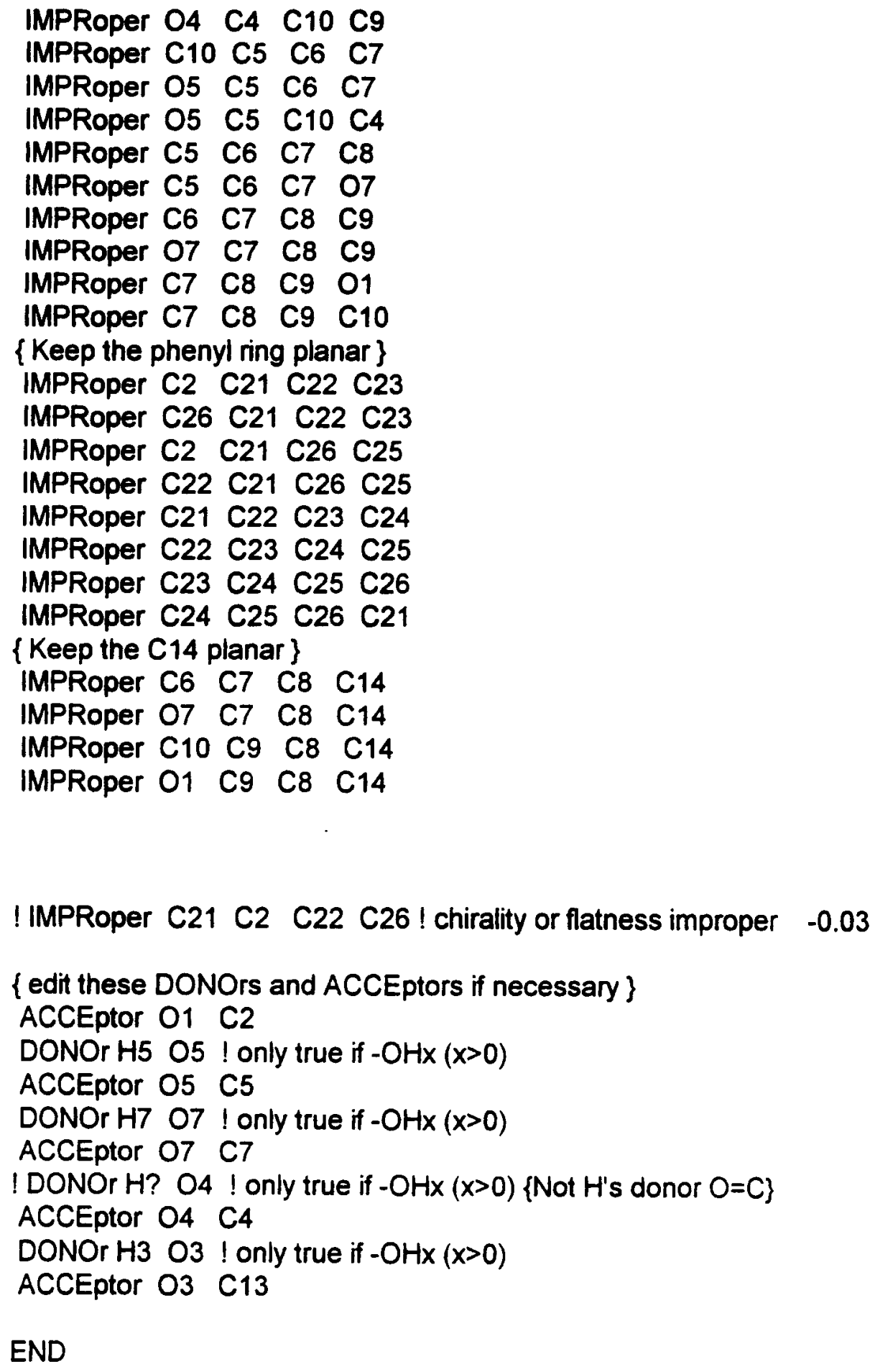

! IMPRoper C21 C2 C22 C26 ! chirality or flatness improper -0.03

\{ edit these DONOrs and ACCEptors if necessary \}

ACCEptor 01 C2

DONOr H5 O5 ! only true if $-\mathrm{OHx}(x>0)$

ACCEptor O5 C5

DONOr $\mathrm{H} 7$ O7 I only true if $-\mathrm{OH} x(x>0)$

ACCEptor $\mathrm{O} 7 \mathrm{C7}$

! DONOr H? O4 ! only true if $-\mathrm{OHx}(x>0)\{$ Not H's donor $\mathrm{O}=\mathrm{C}\}$

ACCEptor $\mathrm{O}_{4} \mathrm{C} 4$

DONOr $\mathrm{H}_{3} \mathrm{O} 3$ ! only true if $-\mathrm{OH} x(x>0)$

ACCEptor $\mathrm{O} 3 \mathrm{C} 13$

END 


\section{APÊNDICE 3}

ARQUIVOS DE TOPOLOGIA USADOS NO REFINAMENTO DO ROSCOVITINE 
Remarks in3.par

Remarks Created by XPLO2D V. 950116/1.2.2 at Sun Feb 25 13:40:19 1996 for user azevedo Remarks Auto-generated by XPLO2D from file i3.pdb

Remarks Parameters for residue type IN3

set echo=faise end

\{ edit if necessary $\}$

BOND CX1 NX2 $1000.01 .470 !$ Nobs $=1$

BOND CX1 CX23 1000.01 .547 ! Nobs $=1$

BOND CX1 CX24 1000.01 .550 ! Nobs $=1$

BOND NX2 CX3 1000.01 .372 ! Nobs $=1$

BOND NX2 CX6 $1000.01 .370 !$ Nobs $=1$

BOND CX3 NX4 1000.01 .350 ! Nobs $=1$

BOND CX3 CX14 1000.01 .370 ! Nobs $=1$

BOND NX4 CX5 1000.01 .328 ! Nobs $=1$

BOND CX5 NX15 1000.01 .360 ! Nobs $=1$

BOND CX5 NX18 1000.01 .340 ! Nobs $=1$

BOND CX19 NX15 $1000.01 .370 !$ Nobs $=1$

BOND CX19 CX14 1000.01 .425 ! Nobs $=1$

BOND CX19 NX17 1000.01 .320 ! Nobs $=1$

BOND CX14 NX16 1000.01 .390 ! Nobs $=1$

BOND NX16 CX6 1000.01 .313 ! Nobs $=1$

BOND NX17 CX7 1000.01 .475 ! Nobs $=1$

BOND CX7 CX8 1000.0. 1.541! Nobs $=1$

BOND CX8 CX9 1000.01 .390 ! Nobs $=2$

BOND CX9 CX20 1000.01 .390 ! Nobs $=1$

BOND CX20 CX21 1000.01 .394 ! Nobs $=1$

BOND CX21 CX22 1000.0 1.390! Nobs $=1$

BOND CX22 CX9 1000.01 .391 ! Nobs $=1$

BOND NX18 CX10 $1000.01 .536 !$ Nobs $=1$

BOND CX10 CX11 1000.01 .538 ! Nobs $=2$

BOND CX11 CX12 $1000.01 .540 !$ Nobs $=1$

BOND CX11 OX13 $1000.01 .450 !$ Nobs $=1$

\{ edit if necessary

ANGLe NX2 CX1 $\quad$ CX23 $500.0 \quad 109.50 !$ Nobs $=1$

ANGLe NX2 $\quad$ CX1 $\quad$ CX24 $500.0 \quad 109.11 !$ Nobs $=1$

ANGLe CX23 CX1 CX24 500.0 110.41 ! Nobs $=1$

ANGLe CX1 NX2 CX3 $500.0 \quad 123.53$ ! Nobs $=1$

ANGLe CX1 NX2 CX6 $500.0 \quad 131.63$ ! Nobs $=1$

ANGLe CX3 NX2 CX6 $500.0 \quad 104.82$ ! Nobs $=1$

ANGLe NX2 CX3 NX4 $500.0 \quad 126.45$ ! Nobs $=1$

ANGLe NX2 $\quad$ CX3 $\quad$ CX14 $500.0 \quad 109.30$ ! Nobs $=1$

ANGLe NX4 $\quad C \times 3 \quad C \times 14 \quad 500.0 \quad 124.21$ ! Nobs $=1$

ANGLe CX3 NX4 CX5 $500.0 \quad 118.01$ ! Nobs $=1$

ANGLe NX4 CX5 NX15 $500.0 \quad 120.32$ ! Nobs $=1$

ANGLe NX4 CX5 NX18 $500.0 \quad 113.11$ ! Nobs = 1

ANGLe NX15 CX5 NX18 $500.0 \quad 126.56$ ! Nobs = 1

ANGLe NX15 CX19 CX14 $500.0 \quad 114.91$ ! Nobs = 1

ANGLe NX15 CX19 NX17 $500.0 \quad 117.80 !$ Nobs $=1$

ANGLe CX14 CX19 NX17 $500.0 \quad 127.25$ ! Nobs = 1

ANGLe CX5 NX15 CX19 $500.0 \quad 124.43$ ! Nobs = 1

ANGLe CX3 CX14 CX19 $500.0 \quad 118.12$ ! Nobs $=1$ 


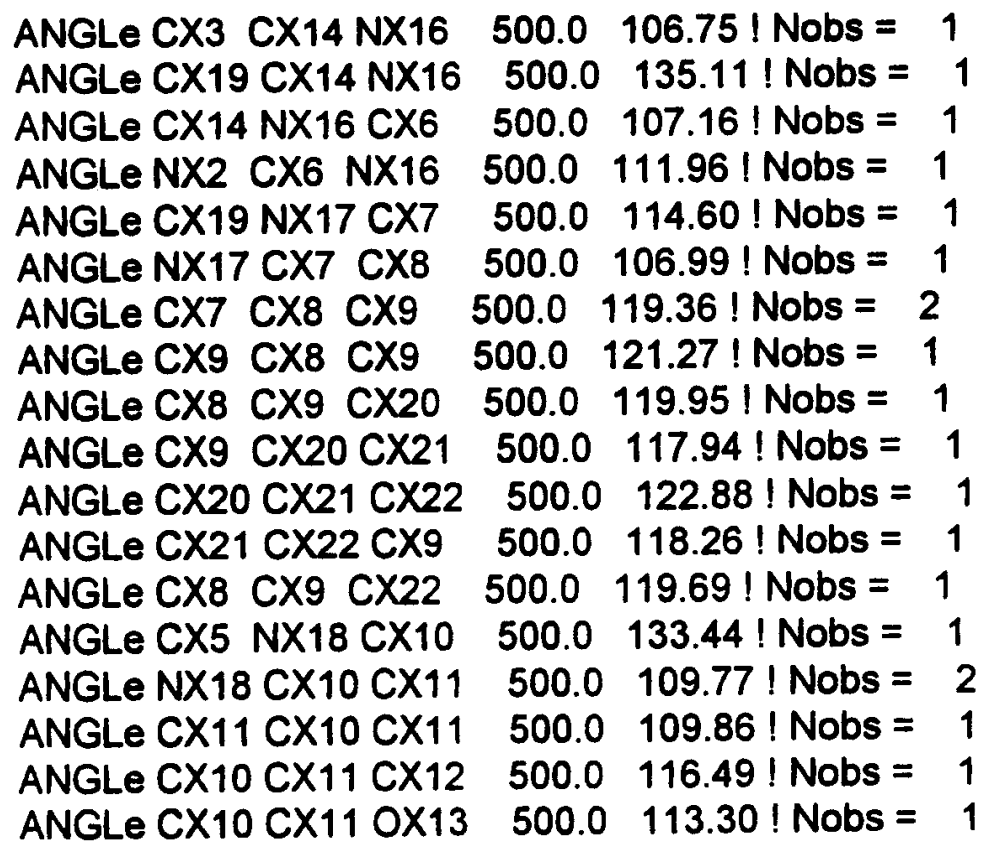

\{ insert DIHEdrals yourself if necessary

\{ suggested weight $=300.0$ for Engh \& Huber compatibility $\}$

\{ edit if necessary \}

IMPRoper CX1 NX2 CX23 CX24 $750.00 \quad 35.250$ ! Nobs $=1$ IMPRoper CX3 NX2 NX4 CX14 $750.00 \quad 0.000$ ! Nobs $=1$ IMPRoper CX5 NX4 NX15 NX18 $750.00 \quad 0.000$ ! Nobs $=1$ IMPRoper CX19 NX15 CX14 NX17 $750.00 \quad 0.000$ ! Nobs = 1 IMPRoper CX14 CX3 CX19 NX16 $750.00 \quad 0.000$ ! Nobs $=1$ IMPRoper CX8 CX7 CX9 CX9 $750.00 \quad 0.000$ ! Nobs $=1$ IMPRoper CX10 NX18 CX11 CX11 750.0 $0 \quad 34.767$ ! Nobs $=1$

\{ edit if necessary \}

NONBonded CX1 0.12003 .7418

NONBonded NX2 0.23842 .8509

NONBonded CX3 0.12003 .7418

NONBonded NX4 0.23842 .8509

NONBonded CX5 0.12003 .7418

NONBonded CX6 0.12003 .7418

NONBonded CX7 0.12003 .7418

NONBonded CX8 0.12003 .7418

NONBonded CX9 0.12003 .7418

NONBonded CX10 0.12003 .7418

NONBonded CX11 0.12003 .7418

NONBonded CX12 0.12003 .7418

NONBonded OX13 0.15912 .8509

0.10003 .3854

0.23842 .8509

0.10003 .3854

0.23842 .8509

0.10003 .3854

0.10003 .3854

0.10003 .3854

0.10003 .3854

0.10003 .3854

0.10003 .3854

0.10003 .3854

0.10003 .3854

0.15912 .8509

0.10003 .3854

NONBonded CX14 0.12003 .7418

NONBonded NX15 0.23842 .8509

0.23842 .8509

NONBonded NX16 0.23842 .8509

0.23842 .8509

NONBonded NX17 0.23842 .8509

0.23842 .8509

NONBonded NX18 0.23842 .8509

0.23842 .8509

NONBonded CX19 0.12003 .7418

0.10003 .3854

NONBonded CX20 0.12003 .7418

0.10003 .3854

NONBonded CX21 0.12003 .7418

0.10003 .3854

NONBonded CX22 0.12003 .7418

0.10003 .3854 
NONBonded CX23 $0.12003 .7418 \quad 0.10003 .3854$

NONBonded CX24 $0.1200 \quad 3.7418 \quad 0.10003 .3854$

set echo=true end 
Remarks in 3.top

Remarks Created by XPLO2D V. 950116/1.2.2 at Sun Feb 25 13:40:18 1996 for user azevedo Remarks Auto-generated by XPLO2D from file i3.pdb

Remarks You *MUST* checkledit MASSes and CHARges !!!

Remarks Check DONOrs and ACCEptors

Remarks Verify IMPRopers yourself

Remarks UNcomment any DIHEdrals you want to use

set echo=false end

\{ edit masses yourself !!! \}

MASS CX1 12.01100! ADD 1.008 for each $H$ MASS NX2 14.00670 ! ADD 1.008 for each $\mathrm{H}$ MASS CX3 12.01100 ! ADD 1.008 for each $H$ MASS NX4 14.00670 ! ADD 1.008 for each $H$ MASS CX5 12.01100 ! ADD 1.008 for each $\mathrm{H}$ MASS CX6 12.01100 ! ADD 1.008 for each $\mathrm{H}$ MASS CX7 12.01100 ! ADD 1.008 for each $H$ MASS CX8 12.01100 ! ADD 1.008 for each $H$ MASS CX9 12.01100 ! ADD 1.008 for each $H$ MASS CX10 12.01100 ! ADD 1.008 for each $\mathrm{H}$ MASS CX11 12.01100! ADD 1.008 for each $H$ MASS CX12 12.01100! ADD 1.008 for each $H$ MASS OX13 15.99940! ADD 1.008 for each $H$ MASS CX14 12.01100! ADD 1.008 for each H MASS NX15 14.00670 ! ADD 1.008 for each $H$ MASS NX16 14.00670 ! ADD 1.008 for each H MASS NX17 14.00670 ! ADD 1.008 for each H MASS NX18 14.00670 ! ADD 1.008 for each $H$ MASS CX19 12.01100 ! ADD 1.008 for each H MASS CX20 12.01100 ! ADD 1.008 for each $H$ MASS CX21 12.01100 ! ADD 1.008 for each $H$ MASS CX22 12.01100! ADD 1.008 for each $H$ MASS CX23 12.01100! ADD 1.008 for each $H$ MASS CX24 12.01100! ADD 1.008 for each $H$

autogenerate angles=true end

RESIdue IN3

GROUp

ATOM C9 TYPE CX1 CHARge 0.0 END ATOM N9 TYPENX2 CHARge 0.0 END ATOM C4 TYPE CX3 CHARge 0.0 END ATOM N3 TYPE NX4 CHARge 0.0 END ATOM C2 TYPE CX5 CHARge 0.0 END ATOM C6 TYPE CX19 CHARge 0.0 END ATOM N1 TYPE NX15 CHARge 0.0 END ATOM C5 TYPE CX14 CHARge 0.0 END ATOM N7 TYPE NX16 CHARge 0.0 END ATOM C8 TYPE CX6 CHARge 0.0 END ATOM N6 TYPE NX17 CHARge 0.0 END ATOM CA' TYPE CX7 CHARge 0.0 END ATOM C1' TYPE CX8 CHARge 0.0 END 
ATOM C2' TYPE CX9 CHARge 0.0 END

ATOM C3' TYPE CX20 CHARge 0.0 END

ATOM C4' TYPE CX21 CHARge 0.0 END

ATOM C5' TYPE CX22 CHARge 0.0 END ATOM C6' TYPE CX9 CHARge 0.0 END ATOM N2 TYPE NX18 CHARge 0.0 END ATOM C12 TYPE CX10 CHARge 0.0 END ATOM C13 TYPE CX11 CHARge 0.0 END ATOM C14 TYPE CX12 CHARge 0.0 END ATOM C15 TYPE CX11 CHARge 0.0 END ATOM 01 TYPE OX13 CHARge 0.0 END ATOM C11 TYPE CX23 CHARge 0.0 END ATOM C10 TYPE CX24 CHARge 0.0 END

$$
\begin{aligned}
& \text { BOND C9 N9 } \\
& \text { BOND C9 C11 } \\
& \text { BOND C9 C10 } \\
& \text { BOND N9 C4 } \\
& \text { BOND N9 C8 } \\
& \text { BOND C4 N3 } \\
& \text { BOND C4 C5 } \\
& \text { BOND N3 C2 } \\
& \text { BOND C2 N1 } \\
& \text { BOND C2 N2 } \\
& \text { BOND C6 N1 } \\
& \text { BOND C6 C5 } \\
& \text { BOND C6 N6 } \\
& \text { BOND C5 N7 } \\
& \text { BOND N7 C8 } \\
& \text { BOND N6 CA' } \\
& \text { BOND CA' C1' } \\
& \text { BOND C1' C2' } \\
& \text { BOND C1' } \mathrm{C}^{\prime} \\
& \text { BOND C2' C3' } \\
& \text { BOND C3' C4' } \\
& \text { BOND C4' C5' } \\
& \text { BOND C5' C6' } \\
& \text { BOND N2 C12 } \\
& \text { BOND C12 C13 } \\
& \text { BOND C12 C15 } \\
& \text { BOND C13 C14 } \\
& \text { BOND C15 } 01
\end{aligned}
$$

\{edit these DIHEdrals if necessary

! DIHEdral C11 C9 N9 C4 ! fixed dihedral ??? 63.44

! DIHEdral C10 C9 N9 C4 ! fixed dihedral ??? -57.50

! DIHEdral C9 N9 C4 N3 ! fixed dihedral ??? 0.03

! DIHEdral C9 N9 C4 C5 ! fixed dihedral ??? -178.07

! DIHEdral C8 N9 C4 N3 ! fixed dihedral ??? 178.52

! DIHEdral C8 N9 C4 $\quad$ C5 ! fixed dihedral ??? 0.42

! DIHEdral C9 N9 C8 N7 ! fixed dihedral ??? 177.92

! DIHEdral C4 N9 C8 N7 ! fixed dihedral ??? -0.40

! DIHEdral N9 C4 N3 C2 ! fixed dihedral ??? -177.90

! DiHEdral C5 C4 N3 C2 ! fixed dihedral ??? -0.07 
1 DIHEdral N9 C4 C5 C6 ! fixed dihedral ??? 178.43

! DIHEdral N9 C4 C5 N7 ! fixed dihedral ??? $\quad-0.30$

! DIHEdral N3 C4 C5 C6 ! fixed dihedral ??? 0.28

! DIHEdral N3 C4 C5 N7 ! fixed dihedral ??? -178.45

! DIHEdral C4 N3 C2 N1 I fixed dihedral ??? -0.03

! DIHEdral C4 N3 C2 N2 ! fixed dihedral ??? 179.24

! DIHEdral N3 C2 N1 C6 ! fixed dihedral ??? -0.09

I DIHEdral N2 C2 N1 C6 ! fixed dihedral ??? -179.26

! DIHEdral C5 C6 N1 C2 I fixed dihedral ??? 0.29

! DIHEdral N6 C6 N1 C2 ! fixed dihedral ??? 178.22

I DIHEdral N1 C6 C5 C4 I fixed dihedral ??? $\quad-0.37$

! DIHEdral N1 C6 C5 N7 ! fixed dihedral ??? 177.91

! DIHEdral N6 C6 C5 C4 ! fixed dihedral ??? -178.06

! DIHEdral N6 $\quad$ C6 $\quad$ C5 N7 ! fixed dihedral ??? 0.22

! DIHEdral C4 C5 N7 C8 ! fixed dihedral ??? 0.05

! DIHEdral C6 C5 N7 C8 ! fixed dihedral ??? -178.36

I DIHEdral C5 N7 C8 N9 ! fixed dihedral ??? 0.22

! DIHEdral $\mathrm{CA}^{\prime} \mathrm{C1}^{\prime} \mathrm{C2}^{\prime} \mathrm{C}^{\prime}$ ! ! fixed dihedral ??? -179.98

! DIHEdral C6' C1' C2' C3' ! fixed dihedral ??? -0.97

! DIHEdral CA' C1' C6' C5' ! fixed dihedral ??? 179.94

! DIHEdral C2' C1' $\mathrm{C6}^{\prime} \mathrm{C5}^{\prime}$ ! fixed dihedral ??? 0.93

! DIHEdral $\mathrm{C1}^{\prime} \mathrm{C2}^{\prime} \mathrm{C}^{\prime} \mathrm{C}^{\prime}$ ' ! fixed dihedral ??? 0.04

I DIHEdral C2' $\mathrm{C3}^{\prime} \mathrm{C4}^{\prime} \mathrm{C5}^{\prime}$ ! fixed dihedral ??? 0.96

! DIHEdral C3' C4' C5' C6' ! fixed dihedral ??? -1.01

! DIHEdral C4' C5' C6' C1' ! fixed dihedral ??? 0.05

\{ edit these IMPRopers if necessary \}

IMPRoper C9 N9 C11 C10 ! chirality or flatness improper 35.25

IMPRoper C4 N9 N3 C5 ! chirality or flatness improper 1.25

IMPRoper C2 N3 N1 N2 ! chirality or flatness improper -0.45

IMPRoper C6 N1 C5 N6 ! chirality or flatness improper -1.17

$\begin{array}{llllll}\text { IMPRoper } & \text { C5 } & \text { C4 } & \text { C6 } & \text { N7 } 7 \text { ! chirality or flatness improper } & 0.82\end{array}$

IMPRoper $\mathrm{C1}^{\prime} \mathrm{CA}^{\prime} \mathrm{C}^{\prime} \mathrm{C6}^{\prime}$ ! chirality or flatness improper 0.55

IMPRoper C12 N2 C13 C15! chirality or flatness improper 34.77

\{ edit these DONOrs and ACCEptors if necessary

! DONOr H? N3 ! only true if $-\mathrm{NHx}(x>0)$

! DONOr H? N1 ! only true if $-\mathrm{NHx}(x>0)$

! DONOr H? N7 ! only true if $-\mathrm{NHx}(x>0)$

! DONOr H? N6! only true if $-\mathrm{NH}(x>0)$

! DONOr H? N2 ! only true if $-\mathrm{NHx}(x>0)$

! DONOr H? O1 ! only true if $-\mathrm{OHx}(x>0)$

ACCEptor 01 C15

END 